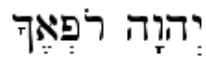

"Yahweh your healer" Exodus 15v26 



\title{
The Australian Cerebral Palsy Research Study - Epidemiological and Genetic Associations with Cerebral Palsy
}

\author{
Michael E. O'Callaghan B.Sc. (Hons.)
}

Thesis submitted for the degree of

Doctor of Philosophy

School of Paediatrics and Reproductive Health, Discipline of Obstetrics and Gynaecology

The University of Adelaide

Submitted March 2011 


\section{Table of Contents}

ABSTRACT ITATEMENT OF DECLARATION

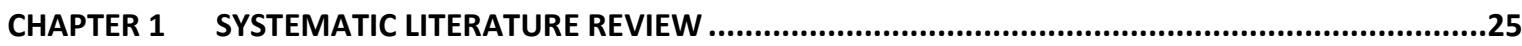

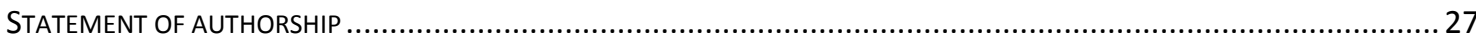

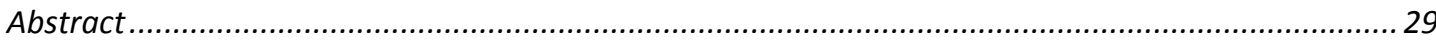

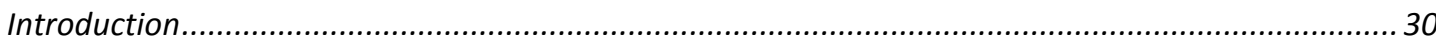

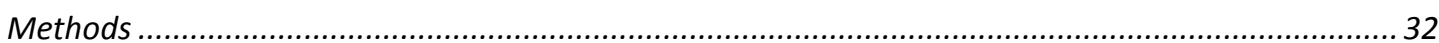

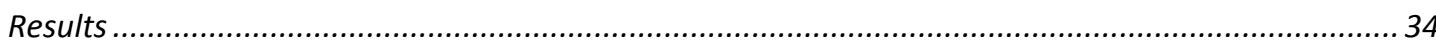

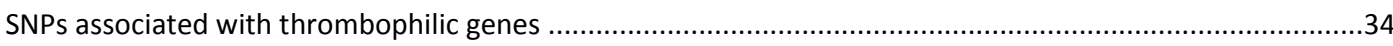

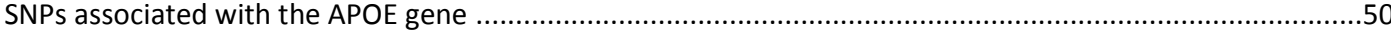

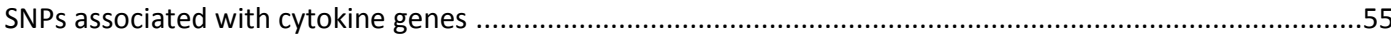

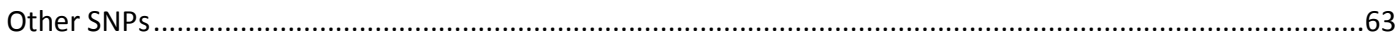

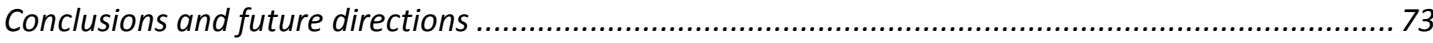

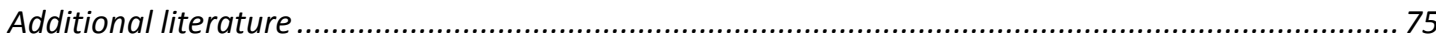

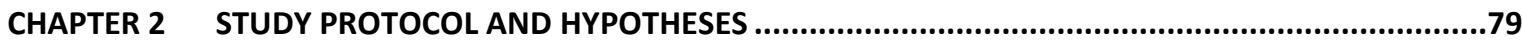

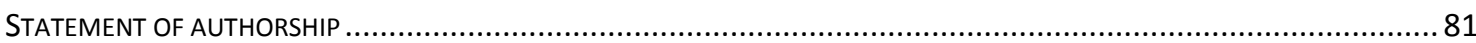

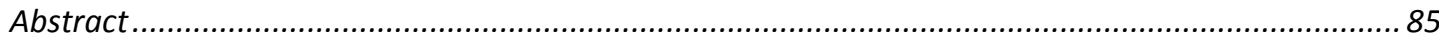

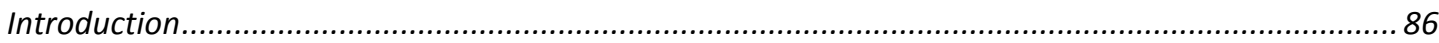

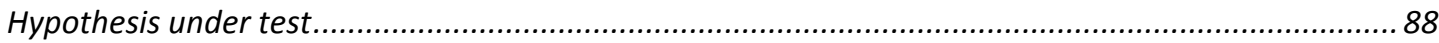

Primary aims

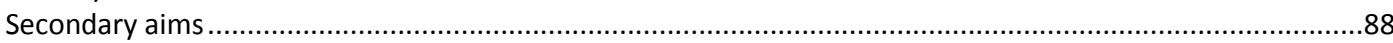

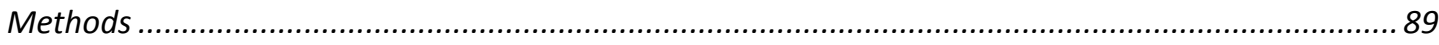

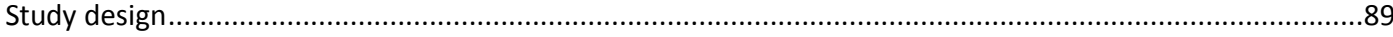

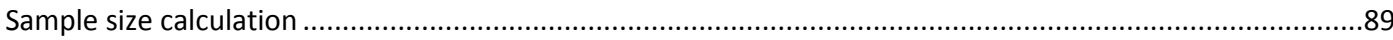

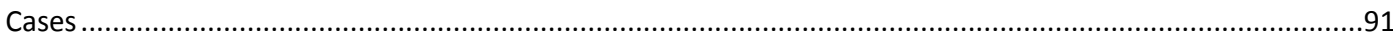

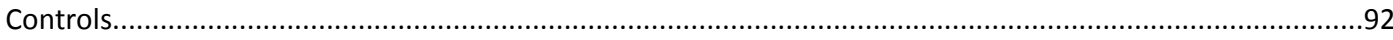

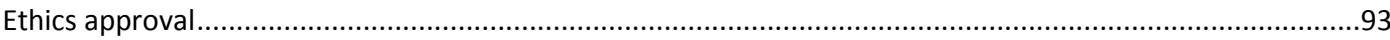

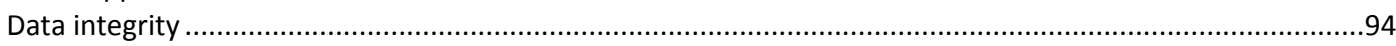

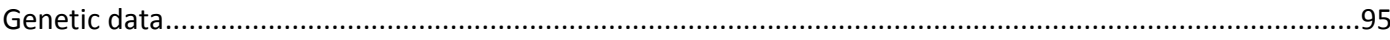

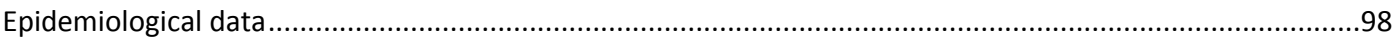

Perinatal outcomes statistics unit (POSU) data linkage ......................................................................103

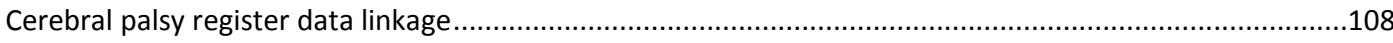

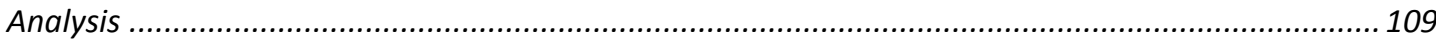

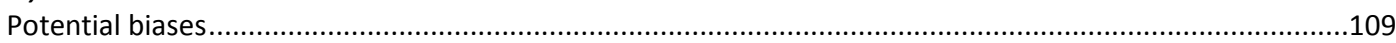

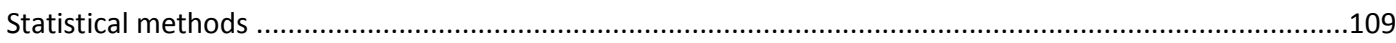

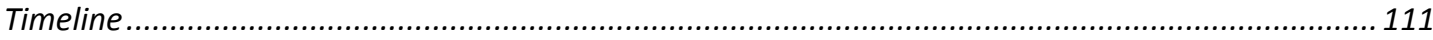

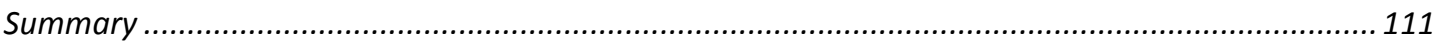

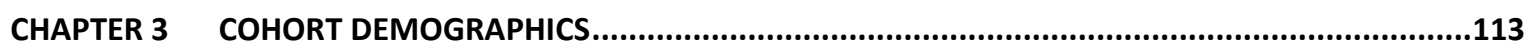

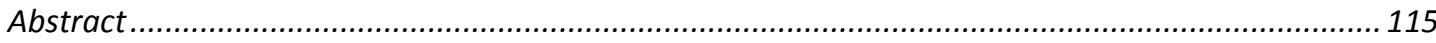

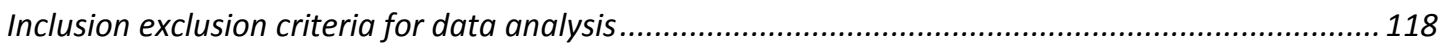

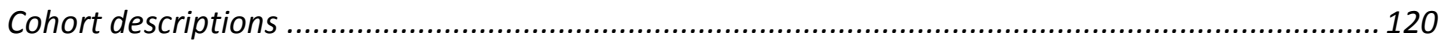

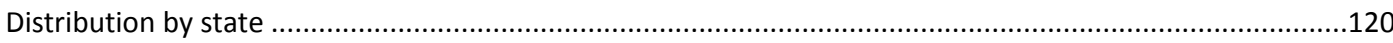

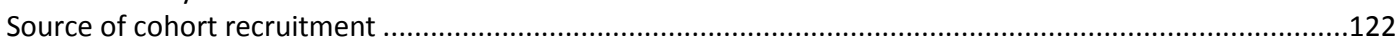

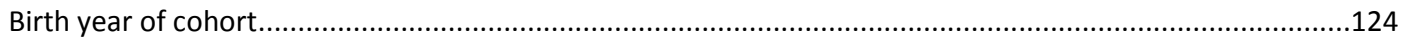




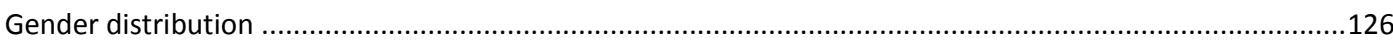

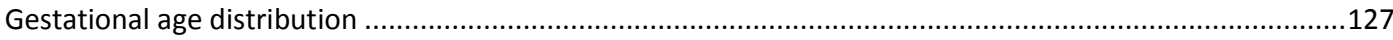

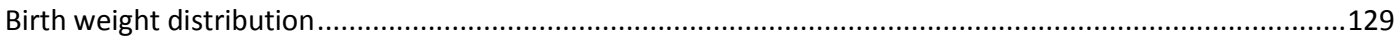

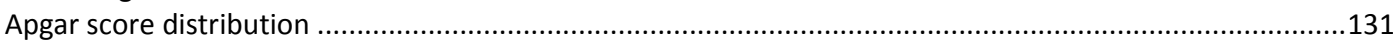

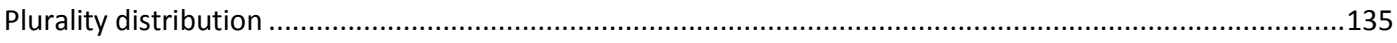

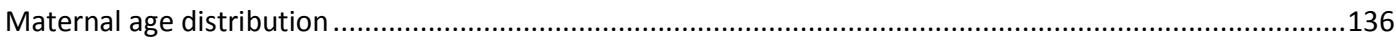

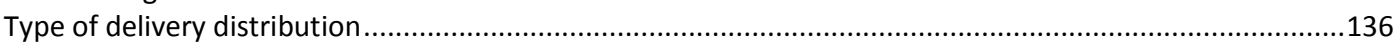

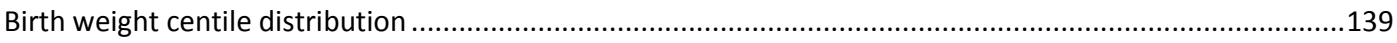

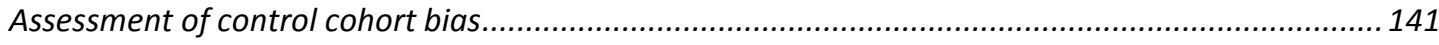

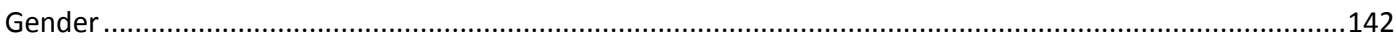

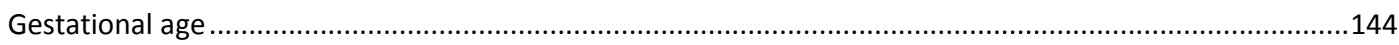

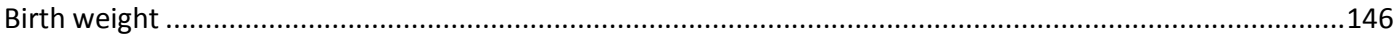

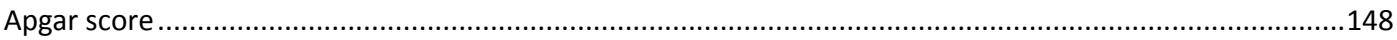

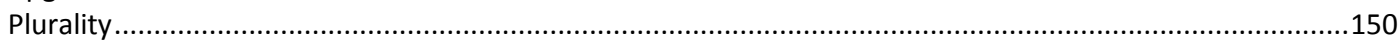

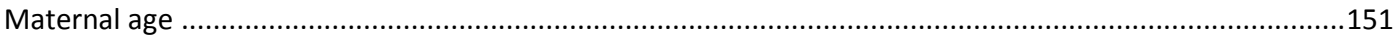

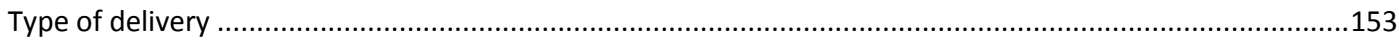

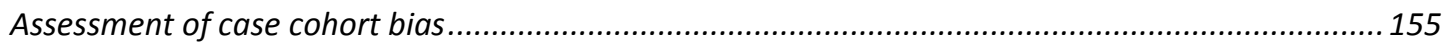

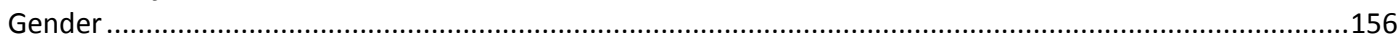

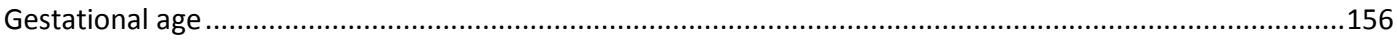

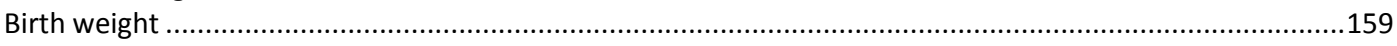

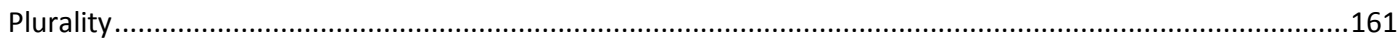

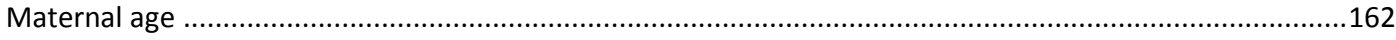

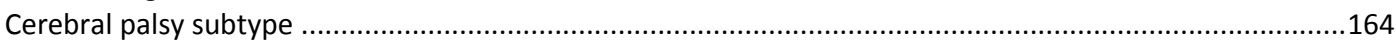

GMFCS (gross motor function classification system) level ......................................................................166

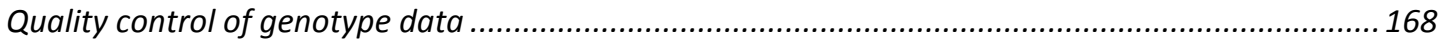

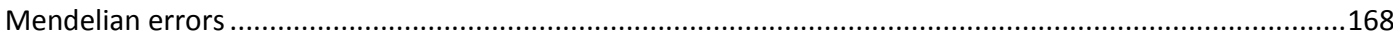

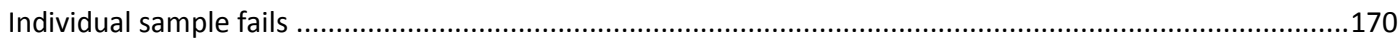

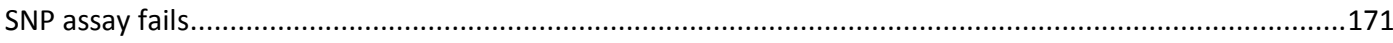

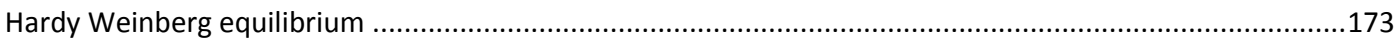

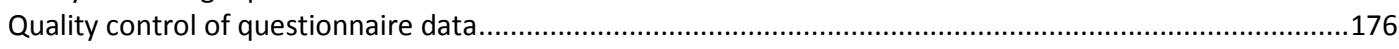

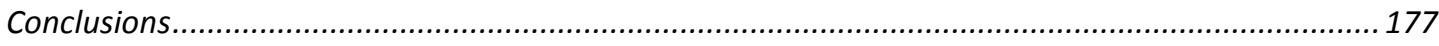

CHAPTER 4 GENETIC ASSOCIATION STUDY IN CHILDREN ..........................................................179

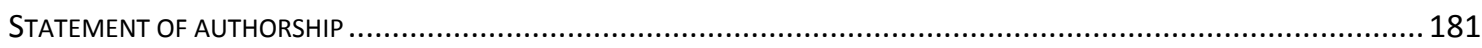

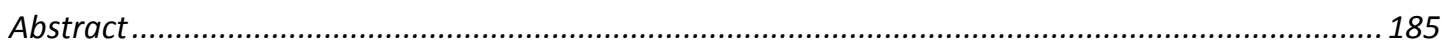

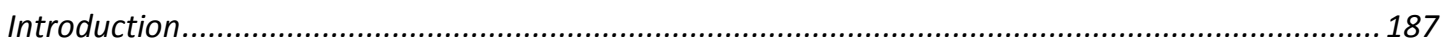

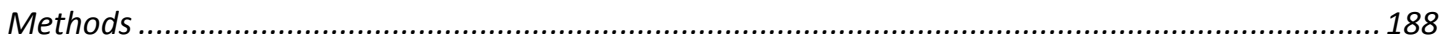

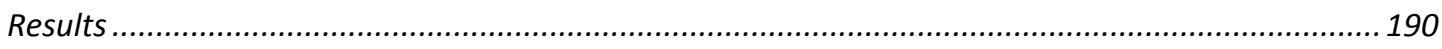

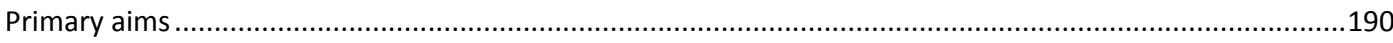

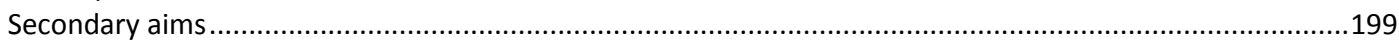

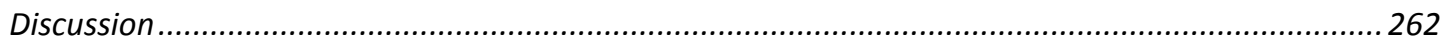

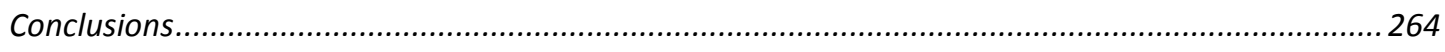

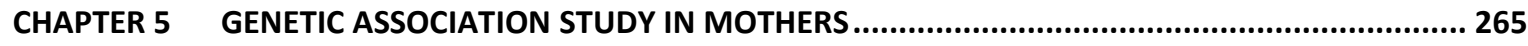

Abstract
Introduction
Methods
Results

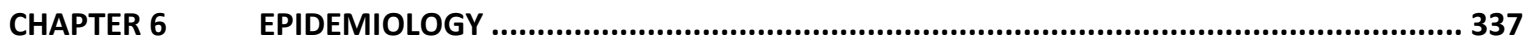

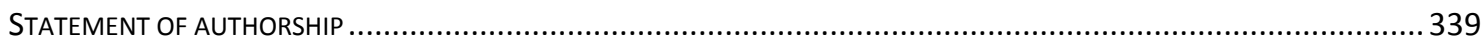

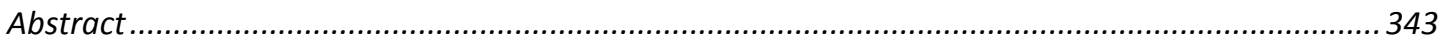

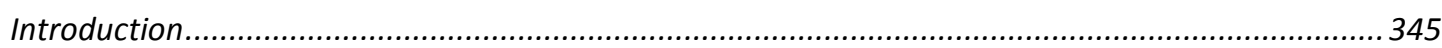

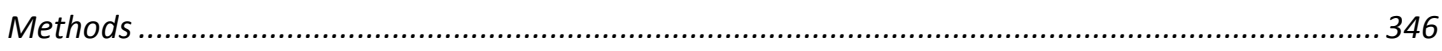

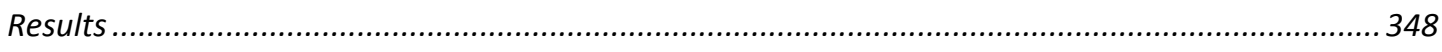

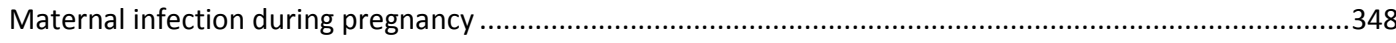




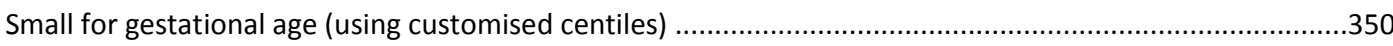

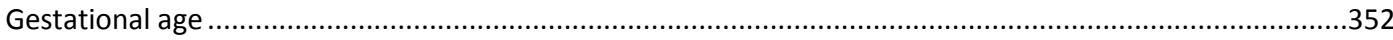

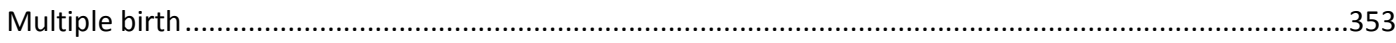

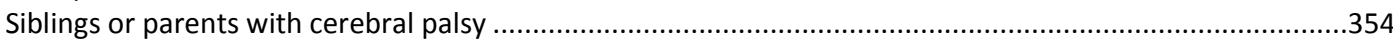

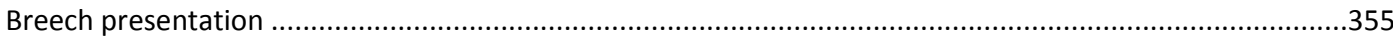

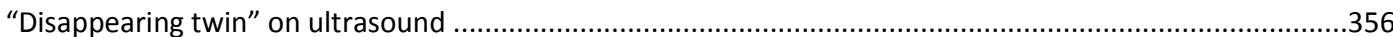

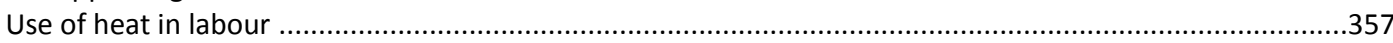

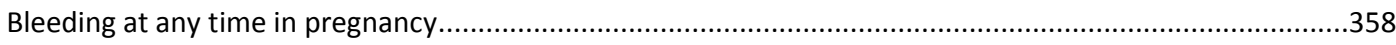

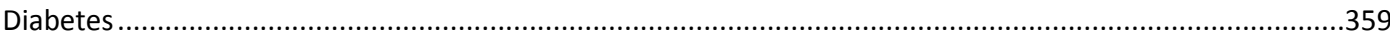

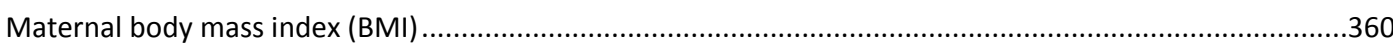

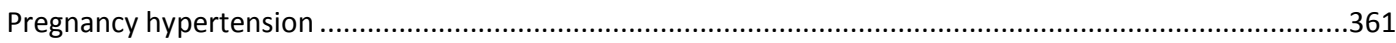

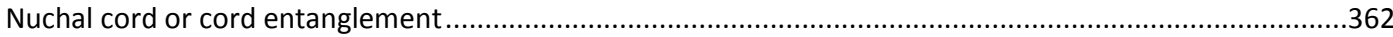

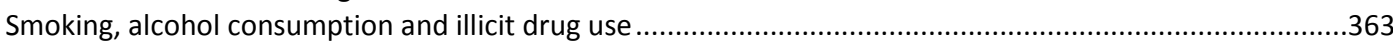

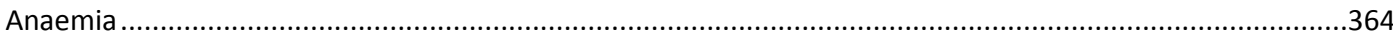

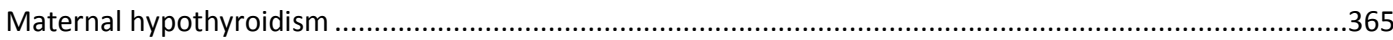

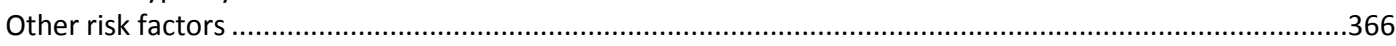

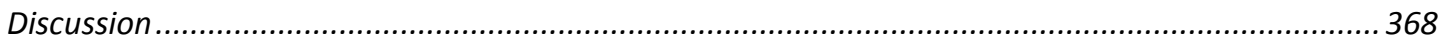

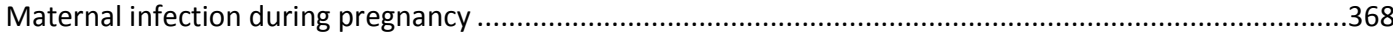

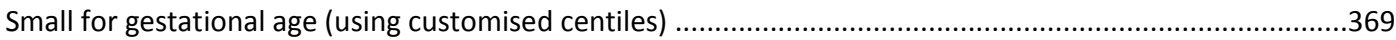

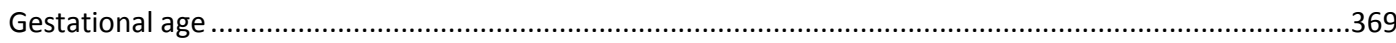

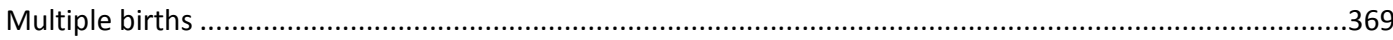

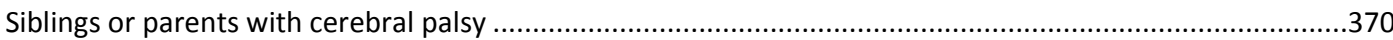

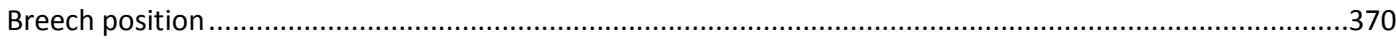

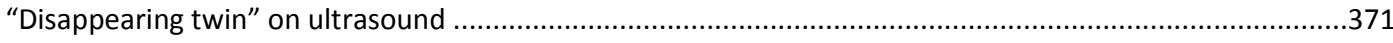

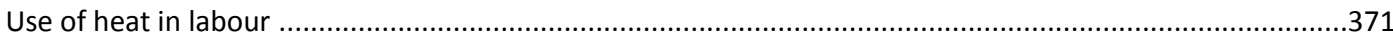

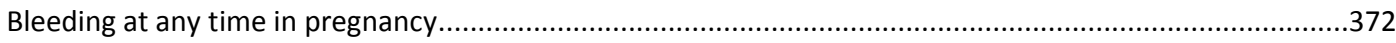

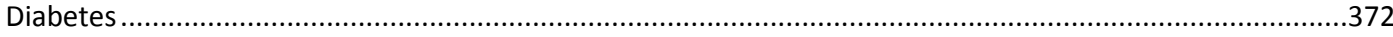

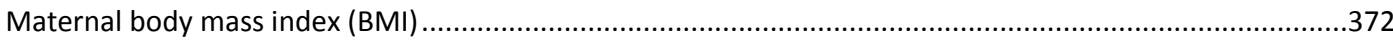

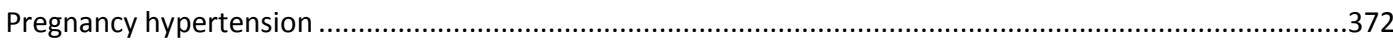

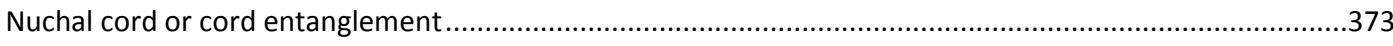

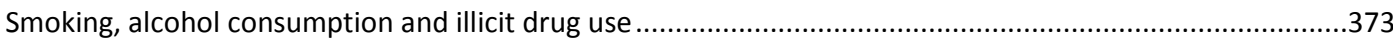

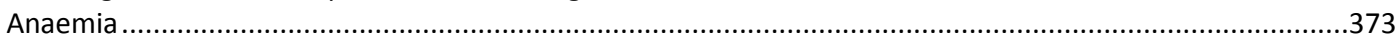

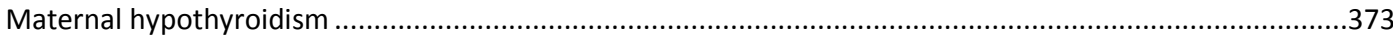

Other risk factors

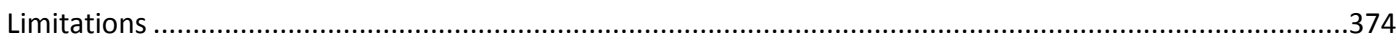

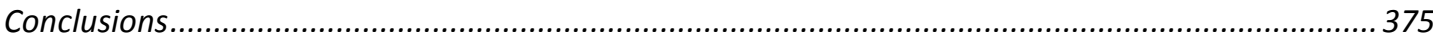

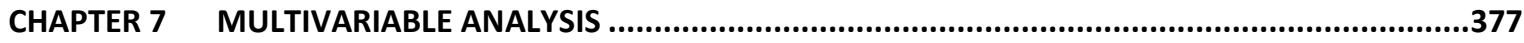

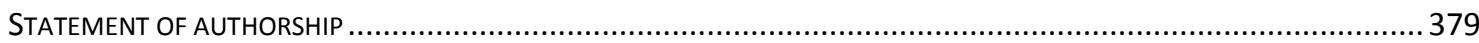

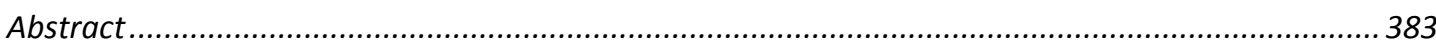

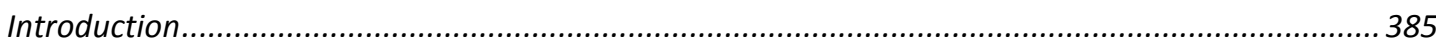

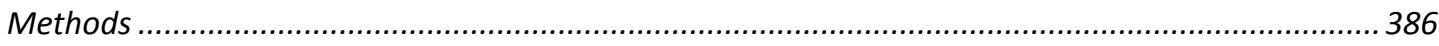

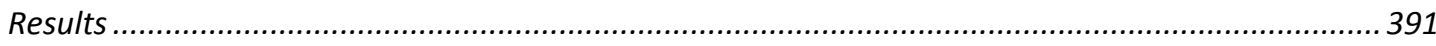

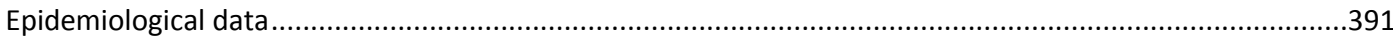

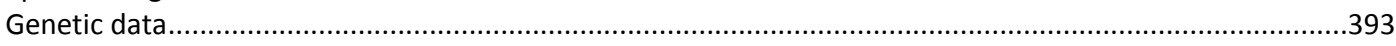

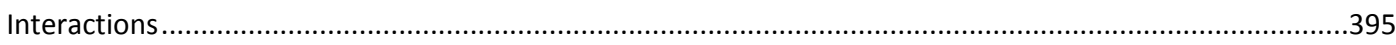

Combined epidemiological and genetic data

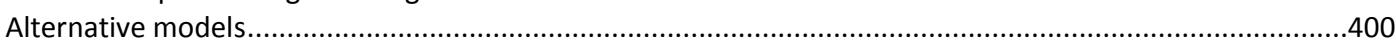

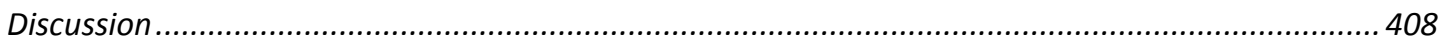

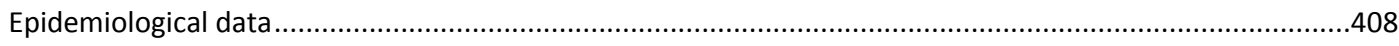

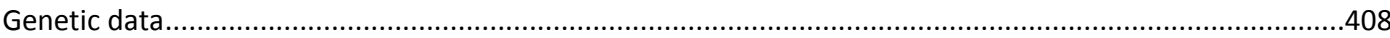

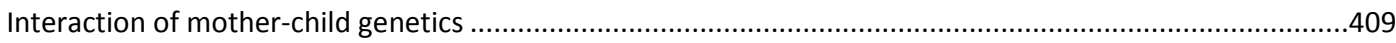

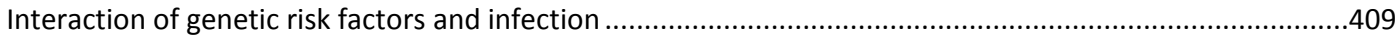

Combined epidemiological and genetic data

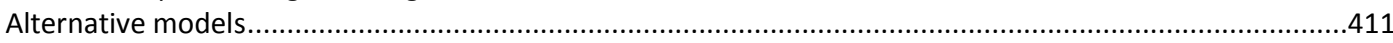

Limitations …

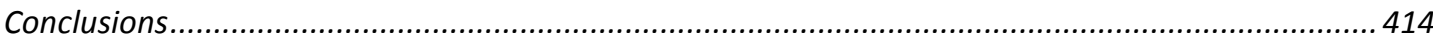

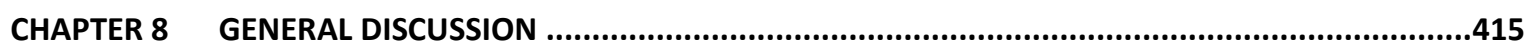

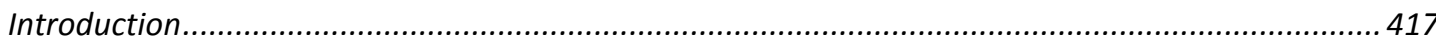

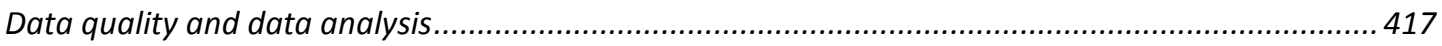




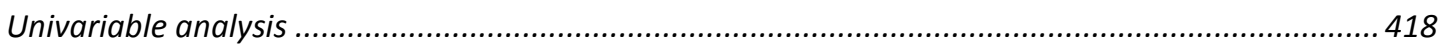

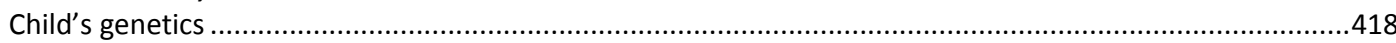

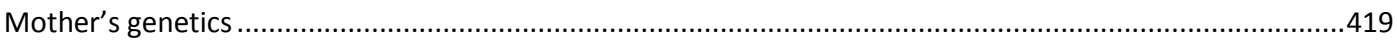

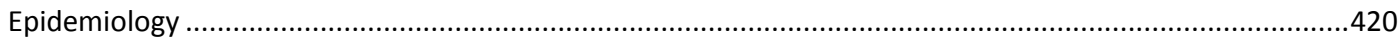

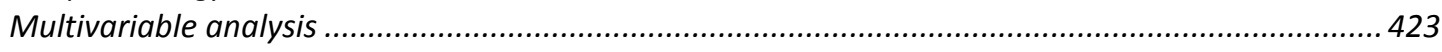

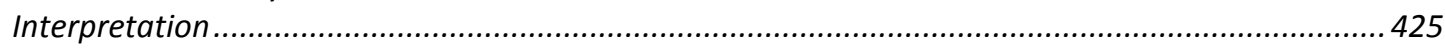

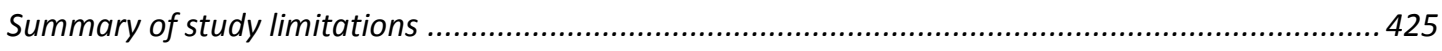

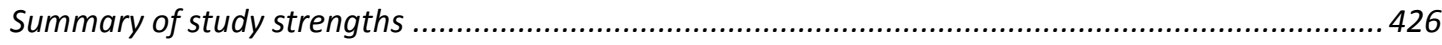

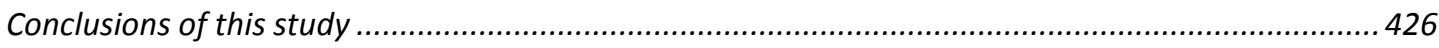

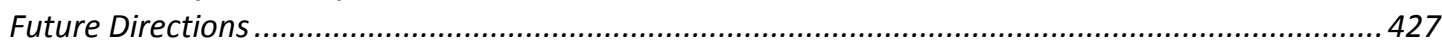

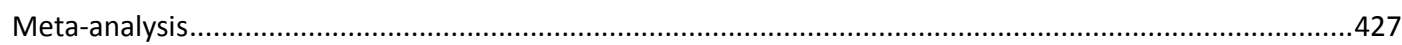

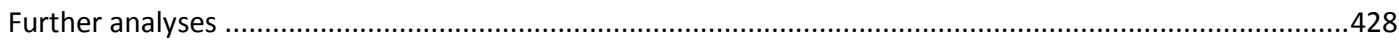

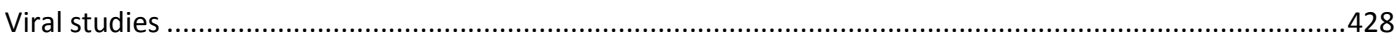

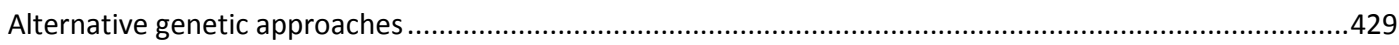

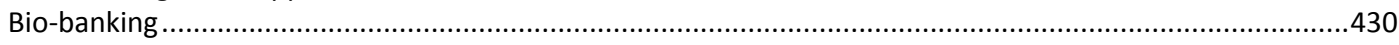

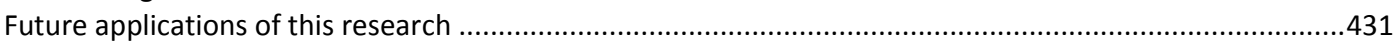

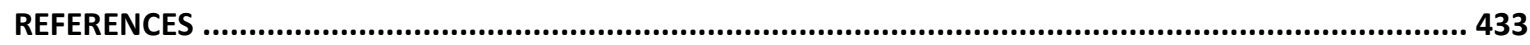

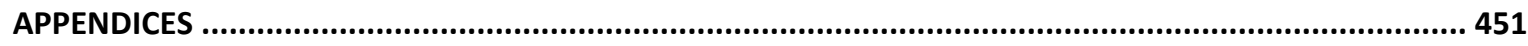

Appendix $1 \quad$ Published systematic literature review (Chapter 1) ....................................... 451

Appendix $2 \quad$ Published study protocol (Chapter 2)........................................................... 475 


\begin{abstract}
Introduction

Twenty two mostly small studies have reported associations between cerebral palsy (CP) and specific single nucleotide polymorphisms (SNPs). These data require prospective confirmation in a large cohort. Only one study has examined maternal genetic risk factors for CP. The current large study of mothers and children examines the contributions of genetic and epidemiological factors to $\mathrm{CP}$ and their interactions.
\end{abstract}

\title{
Methods
}

Caucasian children aged between five and 18 years who were born in Australia were recruited with their mothers. Results from 587 case pairs and 1,154 control pairs were analysed. Each mother and child provided DNA using buccal swabs. Multiplex PCR was used to genotype individuals and 35 specific SNPs were included in the analysis. These candidate SNPs have been putatively associated with thrombophilia, inflammation and preterm birth. Mothers completed a health, pregnancy and delivery questionnaire. State perinatal data for each participant provided further epidemiological data, while CP registers provided cerebral palsy diagnosis data. Univariable analysis examined each epidemiological and genetic risk factor individually with Bonferroni correction for multiple testing. Subsequent multivariable analyses were performed combining risks and examining interactions. Odds ratio (OR) and $95 \%$ confidence intervals are reported.

\section{Results}

Univariable analysis of SNP associations with CP did not confirm the majority of associations reported in the literature after correction for multiple testing. Prothrombin gene mutation in the child remained associated with hemiplegia in term delivered infants where a maternal infection during pregnancy was reported (OR 4.52, 1.70-12.03, $\mathrm{p}=0.059$ after Bonferroni correction). Epidemiological associations with CP included maternal infection during pregnancy 
(OR $1.55,1.26-1.91)$, small for gestational age $\left(<10^{\text {th }}\right.$ centile, OR $\left.4.35,2.92-6.48\right)$, gestational age $<32$ weeks (OR 59.20, 28.87-121.38), multiple birth (OR 6.62, 4.00-10.95), a relative with CP (OR $1.61,1.12-2.32$ ) and male gender (OR 1.68, 1.38-2.06). latrogenic heat in labour did not increase the risk of $\mathrm{CP}$. Multivariable analyses of genetic and epidemiological risk factors identified significant associations of $C P$ with male gender (OR 1.5, 1.1-2.1), reported maternal infection (OR 1.9, 1.2-3.0), a relative with CP (OR 1.8, 1.1-2.9) and maternal carriage of TGF- $\beta 1-509$ (OR 1.3, 1.0-1.6). Subtype analyses showed an increased risk of quadriplegic $C P$ with a family history of $C P$ (OR 3.27, 1.13-9.45). The interaction of maternal TNF- $\alpha 308$ with infection was inversely related to $\mathrm{CP}(\mathrm{OR} 0.7,0.5-0.9)$.

\section{Discussion}

Most SNP associations in the literature were not confirmed by this study, probably because those studies did not correct for multiple testing. The study confirmed the reported epidemiological associations with $\mathrm{CP}$ in the literature. Combined multivariable analyses suggest an association of some maternal and fetal genotypes with CP outcome, particularly when an infection was reported. These results require further study and the mechanism of association is yet to be determined.

\section{Conclusions}

The individual SNPs studied are unlikely to play a large role in CP causation, although maternal SNPs and interactions with infection may be significant. Specific subtypes of CP (particularly term born quadriplegia) are more likely to have a genetic origin than other types. This study has stimulated new genetic and environmental studies of CP. 


\section{Statement of declaration}

This work contains no material which has been accepted for the award of any other degree or diploma in any university or other tertiary institution to Michael E O'Callaghan and, to the best of my knowledge and belief, contains no material previously published or written by another person, except where due reference has been made in the text.

I give consent to this copy of my thesis when deposited in the University Library, being made available for loan and photocopying, subject to the provisions of the Copyright Act 1968.

The author acknowledges that copyright of published works contained within this thesis (as listed below) resides with the copyright holder(s) of those works.

I also give permission for the digital version of my thesis to be made available on the web, via the University's digital research repository, the Library catalogue, the Australasian Digital Theses Program (ADTP) and also through web search engines, unless permission has been granted by the University to restrict access for a period of time.

M.E. O'Callaghan, March 2011. 


\section{Acknowledgements}

I gratefully acknowledge my supervisors, Professor Alastair MacLennan, Professor Eric Haan and Professor Gus Dekker. I am thankful for the opportunity to study under such prominent leaders and I have valued their guidance, advice and patience with me as I prepared this thesis.

I am thankful to Gai McMichael for her support in the laboratory work for this study, Jessica Broadbent for her support in the multiple ethics submissions and Dr. Catherine Gibson for her guidance and advice throughout my candidature.

This collaborative project has received input from all members of the multidisciplinary South Australian Cerebral Palsy Research Group. I gratefully acknowledge the help of Kevin Priest, Associate Professor Annabelle Chan, Dr. Ray Russo, Professor Jozef Gecz, Professor Paul Goldwater, Heather Scott, Dr. Heather Tapp, Professor Yee Khong, and Dr. Suzanna Thompson.

This study would not have been possible without the participation of volunteering families from around Australia. I am thankful for their contribution and also to our collaborators in each state of Australia.

South Australia: Novita Children's Services (Dr. Parimala Raghavendra and Dr. Lloyd Walker), Perinatal Outcome Statistics Unit (Dr. Annabelle Chan), South Australian Cerebral Palsy Register (Phillipa van Essen).

Queensland: The Cerebral Palsy League of Queensland (Dr. Leanne Johnston), the Cerebral Palsy Register (Michael Delacy) and Queensland Health.

New South Wales: The Spastic Centre, The Cerebral Palsy Register (Sarah Mclntyre) and the Cancer Institute of NSW (Lee Taylor). 
Victoria: SCOPE (Michael Bink), The Cerebral Palsy Register (Associate Professor Dinah Reddihough and Sue Reid) and The Consultative Council on Obstetric and Paediatric Mortality and Morbidity (Professor Jeremy Oats).

Tasmania: The Cerebral Palsy Register (Julie Bunyard), Associate Professor Peter Flett and the Department of Health and Human Services (Peter Mansfield).

Western Australia: The Centre for Cerebral Palsy (Dr. Marie Blackmore), The Cerebral Palsy Register (Associate Professor Eve Blair and Linda Watson) and the Department of Health WA (Alex Godfrey).

Australia Capital Territory: ACT Health (Rosalind Sexton).

I am thankful for the statistical advice and tutoring I have received from Professor Grant Montgomery, Dr. Jodie Painter, Associate Professor Peter Baghurst and Georgia Antoniou.

I especially thank my wife Abby and our daughter Shoshanna for their love and support. 


\section{Publications arising from this thesis}

1. O'Callaghan ME, MacLennan AH, Haan EA, Dekker G; South Australian Cerebral Palsy Research Group.

The Genomic Basis of Cerebral Palsy: a HuGE Systematic Literature Review. Human Genetics. 2009 July;126(1):149-72. Published online Feb 242009. This paper was invited by the editors to be part of a special edition of Human Genetics on Neurological and Psychiatric Diseases and Traits.

2. O'Callaghan ME, MacLennan AH, Gibson CS, McMichael GL, Haan EA, Broadbent J, Priest K, Goldwater PN, Dekker GA.

The Australian Cerebral Palsy Research Study - Protocol for a National Collaborative Study Investigating Genomic and Clinical Associations with Cerebral Palsy.

Journal of Paediatrics and Child Health. 2010 Nov 21. doi: 10.1111/j.14401754.2010.01896.x. Published online ahead of print. 


\section{Publications submitted or in preparation}

1. O'Callaghan ME, MacLennan AH, Gibson CS, McMichael GL, Haan EA, Broadbent JL, Goldwater PN, Painter JN, Montgomery GW, Dekker GA. for the Australian Collaborative Cerebral Palsy Research Group.

Fetal and Maternal Candidate SNP Associations with Cerebral Palsy in a Large Case-Control Study.

Manuscript submitted March 2011.

2. O'Callaghan ME, MacLennan AH, Gibson CS, McMichael GL, Haan EA, Broadbent JL, Priest K, Goldwater PN, Dekker GA, for the Australian Collaborative Cerebral Palsy Research Group.

Epidemiological Risk Factors Associated with Cerebral Palsy in a Large CaseControl Study.

Manuscript in preparation.

3. O'Callaghan ME, MacLennan AH, Gibson CS, McMichael GL, Haan EA, Broadbent JL, Baghurst P, Goldwater PN, Dekker GA, for the Australian Collaborative Cerebral Palsy Research Group.

A Multivariable Model of Cerebral Palsy Prediction Utilising Genetic and Epidemiological Risk Factors.

Manuscript in preparation. 


\section{Publications relating to this study but not included in this thesis}

1. McMichael GL, Gibson CS, O'Callaghan ME, Goldwater PN, Dekker GA, Haan EA, MacLennan AH; South Australian Cerebral Palsy Research Group.

DNA from Buccal Swabs Suitable for High-throughput SNP Multiplex Analysis. Journal of Biomolecular Techniques. 2009 Dec;20(5):232-5.

2. McMichael GL, Highet AR, Gibson CS, Goldwater PN, O'Callaghan ME, Alvino E, MacLennan AH for the South Australian Cerebral Palsy Research Group.

Comparison of DNA Extraction Methods from Small Samples of Newborn Screening Cards Suitable for Retrospective Perinatal Viral Research.

Journal of Biomolecular Techniques. Accepted manuscript.

3. O'Callaghan ME, MacLennan AH, Haan EA, Broadbent JL, Baghurst P, Dekker GA for the Australian Collaborative Cerebral Palsy Research Group.

Maternal Recollection of Perinatal Details over Time - A Comparison of Retrospective Questionnaires and State Held Data in an Australian Setting. Manuscript in preparation.

4. O'Callaghan ME, MacLennan AH, Gibson CS, McMichael GL, Haan EA, Broadbent JL, Priest K, Goldwater PN, Dekker GA, for the Australian Collaborative Cerebral Palsy Research Group.

Fetal and Maternal Candidate SNP Associations with Adverse Pregnancy Outcomes in a Large Case-Control Study.

Manuscript in preparation. 


\section{Conference abstracts}

1. O'Callaghan ME, Gibson CS, MacLennan AH, Goldwater P, Haan EA, McMichael G, Paine B, Broadbent J, Priest K, Dekker G for The South Australian Cerebral Palsy Research Group.

Australian Collaborative Study of Genomic and Environmental Factors Associated with Cerebral Palsy. Poster presentation, The 3rd International Cerebral Palsy Conference, February 18-21, 2009 - Sydney, NSW.

2. O'Callaghan ME, MacLennan AH, Gibson CS, McMichael GL, Haan EA, Broadbent JL, Priest K, Painter JN, Montgomery GW, Baghurst PA, Dekker GA for The South Australian Cerebral Palsy Research Group.

The Australian Cerebral Palsy Research Study - Epidemiological and Genetic Associations with Cerebral Palsy. Accepted plenary presentation, Perinatal Medicine, June 15 -17, 2011 - Harrogate, UK. Abstract awarded Student Prize by the British Maternal and Fetal Medicine Society. 


\begin{tabular}{|c|c|}
\hline \multicolumn{2}{|c|}{ Abbreviations } \\
\hline ADRB2 & Beta-2-adrenergic receptor \\
\hline AGT & Angiotensinogen \\
\hline APOE & Apolipoprotein E \\
\hline $\mathrm{Cl}$ & Confidence interval \\
\hline CMV & Cytomegalovirus \\
\hline cox-2 & Cyclo-oxygenase-2 \\
\hline CP & Cerebral Palsy \\
\hline eNOS & Endothelial nitric oxide synthase \\
\hline FGB & Fibrinogen beta chain \\
\hline FVL & Factor V Leiden \\
\hline GA & Gestational age \\
\hline IL-10 & Interleukin 10 \\
\hline IL-1B & Interleukin $1 \beta$ \\
\hline IL-6 & Interleukin 6 \\
\hline ITGB3 & Integrin beta chain beta 3 \\
\hline IUGR & Intrauterine growth restriction \\
\hline LTA & Lymphotoxin- $\alpha$ \\
\hline MBL & Mannose binding lectin \\
\hline MMP & Matrix metalloproteinases \\
\hline MTHFR & Methylenetetrahydrofolate reductase \\
\hline NPPA & Natriuretic peptide A \\
\hline
\end{tabular}


OR

PAl Plasminogen activator

PGM Prothrombin gene mutation

POSU Perinatal outcome statistics unit

SCNN1A Amiloride-sensitive sodium channel subunit alpha

SELE

SNP

TLR-4

TNF- $\alpha$

Glossary

Quadriplegia Paralysis of all four limbs

Diplegia Paralysis of corresponding parts on both sides of the body, typically affecting the legs more severely than the arms

Hemiplegia Paralysis of one side of the body

Pyrexia Raised body temperature, fever 
Chapter 1 Systematic Literature Review

Chapter 1 Systematic Literature Review 
The Genomic Basis of Cerebral Palsy: A HuGE Systematic Literature Review*

O'Callaghan $\mathrm{ME}^{1}$, MacLennan $\mathrm{AH}^{1}$, Haan $\mathrm{EA}^{2}$, Dekker $\mathrm{G}^{1}$, for the South Australian Cerebral Palsy Research Group.

Human Genetics. 2009 July;126(1):149-72.

${ }^{1}$ Discipline of Obstetrics and Gynaecology, School of Paediatrics and Reproductive Health, The Robinson Institute, University of Adelaide, South Australia.

${ }^{2}$ Department of Genetic Medicine, SA Pathology, Women's and Children's Hospital and Discipline of Paediatrics, The University of Adelaide, Adelaide, South Australia.

* Published paper appears in this thesis as Chapter 1 


\section{Chapter 1 Systematic Literature Review}

\section{Statement of authorship}

The Genomic Basis of Cerebral Palsy: a HuGE Systematic Literature Review

Human Genetics. 2009 July;126(1):149-72. Published online Feb 242009.

O'Callaghan ME (Candidate)

Conducted all literature searches, identified relevant papers, synthesised data, interpreted data and prepared the manuscript.

I hereby certify that the statement of contribution is accurate

\section{MacLennan AH}

Primary supervisor, contributed to the study design, data interpretation and manuscript.

I hereby certify that the statement of contribution is accurate 


\section{Chapter $1 \quad$ Systematic Literature Review}

\section{Haan EA}

Co-supervisor, contributed to the study design, data interpretation and manuscript.

I hereby certify that the statement of contribution is accurate

\section{Dekker GA}

Co-supervisor, contributed to the study design, data interpretation and manuscript.

I hereby certify that the statement of contribution is accurate

\section{The South Australian Cerebral Palsy Research Group}

A multidisciplinary group chaired by Professor Alastair MacLennan, who is Head of the Discipline of Obstetrics and Gynaecology in the School of Paediatrics and Reproductive Health at the University of Adelaide. All named authors of this paper are members of the group and wrote the paper on the group's behalf (group listed in acknowledgements). 


\section{Chapter $1 \quad$ Systematic Literature Review}

\section{Abstract}

\section{Introduction}

Cerebral palsy has been associated with a number of candidate genes. To date, no systematic review has been conducted to synthesise genetic polymorphism associations with cerebral palsy.

\section{Methods}

We apply the HuGE NET guidelines to search PubMed and EMBASE databases for publications investigating single nucleotide polymorphisms (SNPs) and cerebral palsy outcome.

\section{Results}

22 papers were identified and are discussed in this review. Candidate genes were grouped as 1) thrombophilic, 2) cytokine, 3) Apolipoprotein E (APOE) or 4) other SNPs, largely related to cardiovascular physiology/pathophysiology and the functioning of the immune system.

\section{Discussion}

Of the studies identified, cohorts were usually small, without adequate control and ethnically diverse, making direct comparison between studies difficult. The most promising candidate genes include Factor V Leiden (FVL), Methylenetetrahydrofolate reductase (MTHFR), Lymphotoxin- $\alpha$ (LTA), Tumour Necrosis Factor- $\alpha$ (TNF- $\alpha)$, eNOS and Mannose binding lectin (MBL).

\section{Conclusions}

Large case-control studies are needed to confirm these candidates with attention given to cohort ethnicity, cerebral palsy subtype analysis and possible multiple gene and geneenvironment interactions. 


\section{Chapter $1 \quad$ Systematic Literature Review}

\section{Introduction}

Cerebral palsy is defined as "a group of permanent disorders of the development of movement and posture, causing activity limitation that are attributed to non-progressive disturbances that occurred in the developing fetal or infant brain. The motor disorders of cerebral palsy are often accompanied by disturbances of sensation, perception, cognition, communication, and behaviour, by epilepsy, and by secondary musculoskeletal problems" ${ }^{1}$.

The cause of cerebral palsy has been studied for more than 50 years. Historically cerebral palsy has been attributed to birth hypoxia, however recent evidence suggests that this is only true in less than $10 \%$ of cases ${ }^{2}$. Many purported cases of birth asphyxia have signs of chronic fetal compromise. Over the past thirty years, the caesarean section delivery rate in Australia has increased 6 fold; however there has been no reduction in the incidence of cerebral palsy ${ }^{3}$. There have also been substantial improvements to fetal monitoring during labour including electronic fetal monitoring and this to has had no effect on the incidence. Cerebral palsy continues to be diagnosed in one in 500 babies born in Australia a level that has remained consistent for many decades.

Landmark studies by Nelson et $a l^{4}$ demonstrated provided the first evidence that many risk factors for cerebral palsy were present before labour commenced and even before the time of conception. Risk factors of note for cerebral palsy include prematurity, intrauterine growth restriction, maternal infection during pregnancy, multiple pregnancy, antepartum haemorrhage, breech presentation, congenital anomalies and perinatal stroke. How the fetus responds in the presence of these risk factors is influenced by its genetic makeup with some genotypes creating susceptibility to cerebral damage ${ }^{5,6}$. Maternal genotype may also play a role by influencing the in utero environment that the fetus is developing within. Further clinical risk factors such as chromosomal anomilies, male predominance, a family history of cerebral palsy and advanced maternal age suggest that cerebral palsy may be, at least in part, determined by genetic influences. 


\section{Chapter 1 Systematic Literature Review}

The genetics of cerebral palsy has been examined by a number of research groups to date. The majority of studies have tested the hypothesis that carriage of functional single nucleotide polymorphisms (SNPs) that influence pathways of thrombosis and infection may predispose to cerebral palsy. The studies examined different populations with varying associations reported, but there has been no systematic analysis of all studies to date. This review uses the Human Genome Epidemiology Network (HuGE NET) guidelines to systematically review all association studies of SNPs and cerebral palsy, summarising the results and recommending directions for future research. 


\section{Chapter $1 \quad$ Systematic Literature Review}

\section{Methods}

Literature searches were conducted using the HUGE NET guidelines. In brief, literature within the MEDLINE (using Pubmed interface) and EMBASE (using OvidSP interface) databases was searched until November 2008. Search terms included "cerebral palsy" in combination with: genome, gene, gene mutation, genetic, genetic polymorphism, genotype, polymorphism, allele, SNP and haplotype. References were combined and duplicates were eliminated. Publications were then excluded based upon title and abstract and the full text was studied for the remaining papers. Where no abstract was available, full text articles were also examined to determine inclusion. Literature was limited to studies reporting SNP associations with cerebral palsy. Secondary database searches combining "cerebral palsy" with the specific genes identified were then performed. These genes included: Mannose binding lectin (MBL), Factor $V$ Leiden (FVL), Prothrombin gene mutation (PGM), Apolipoprotein E (APOE), cyclo-oxygenase-2 (COX-2), Methylenetetrahydrofolate reductase (MTHFR), Tumour necrosis factor- $\alpha$ (TNF-a), Interleukin 10 (IL-10), Angiotensin-1, Interleukin 6 (IL-6) Factor VII -323 10bp del/ins, Factor VII arg353gln (protein annotation is used where studies do not report specific nucleotide substitutions), Fibrinogen beta chain (FGB) -455, Plasminogen activator 1 (PAI-1) -675, PAl1 -11053, Lymphotoxin- $\alpha$ (LTA) thr26asn, Interleukin $1 \beta$ (IL-1B), Toll-like receptor 4 (TLR-4), endothelial nitric oxide synthase (eNOS) -922, eNOS -690, eNOS glu298asp, adducing 1 (ADD1) gly460trp, beta-2-adrenergic receptor (ADRB2) gln27glu, angiotensinogen (AGT) met235thr, AGRT1 -1166, GNB3 -825, ATGA2 -873, Integrin beta chain beta 3 (ITGB3) leu33pro, matrix metalloproteinases (MMP)3 -1171, natriuretic peptide A (NPPA) -664, NPPA -2238, Amiloride-sensitive sodium channel subunit alpha (SCNN1A) trp493ag, SCNN1A ala663thr, selectin E (SELE) ser128arg and SELE leu554phe. 22 publications met these criteria. They included studies published from 1997 through to November 2008 (Figure 1). 
Figure 1

Schematic representation of literature searches conducted. Search terms included "cerebral palsy" and: genome, gene, gene mutation, genetic, genetic polymorphism, genotype, polymorphism, allele, SNP and haplotype. Secondary search terms included "cerebral palsy" and the genes indentified in original searches.

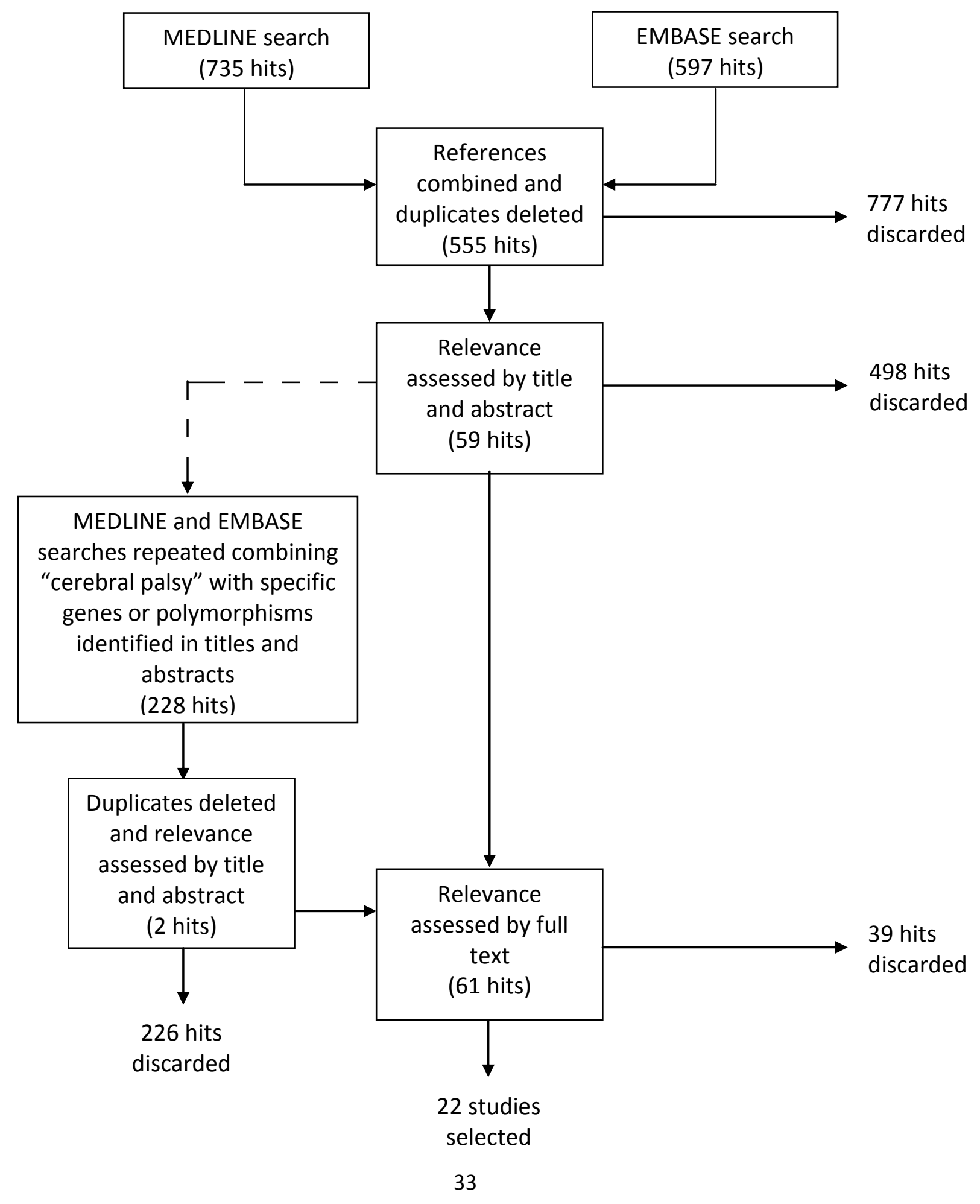




\section{Chapter $1 \quad$ Systematic Literature Review}

\section{Results}

Twenty two papers were selected that examined SNP associations with cerebral palsy outcome. For clarity, these SNPs will be discussed as follows: SNPs associated with thrombophilic genes (Table 1), SNPs associated with the APOE gene (Table 2), SNPs associated with cytokine genes (Table 3) and other SNPs (Table 4). Where studies examined multiple SNPs and individual SNPs fell into more than one category, the paper is discussed in each related group.

\section{SNPs associated with thrombophilic genes}

Eighteen SNPs in 14 studies have been examined for association with cerebral palsy outcome (FVL [includes arg506gln or G1691A], Prothrombin G20210A, MTHFR C677T, MTHFR A1298C, FVII -323 10bp del/ins, FVII arg353gIn, FGB -455, PAI1 -675, PAl1 -11053, Endothelial Protein Receptor C A4600G, TFPI -33 T $\rightarrow$ C, CBS I278T, ANX5 1C $\rightarrow$ T, THBD A43T, PAI-2 N120D, N404K, S413C, PLAT-33C/T).

Physiology of thrombophilic gene SNPs

Factor $V$ Leiden

To date, Factor $V$ Leiden (FVL) is the most extensively investigated thrombophilic SNP. Activated factor $\mathrm{V}$ promotes blood coagulation through cleavage of prothrombin to thrombin. The level of activated factor $V$ is modulated by activated protein C. Carriage of FVL prevents regulation of factor $\mathrm{V}$ by activated protein $\mathrm{C}$ and results in a shift of the coagulation balance towards thrombosis ${ }^{12}$.

\section{Prothrombin}

Prothrombin (factor II) is cleaved to thrombin by factor X. Thrombin activates fibrinogen and factors V, VIII and XI, promoting coagulation. The SNP prothrombin G20210A is associated with increased prothrombin levels and a 2.8 fold increased risk of thrombotic events ${ }^{13,14}$.

\section{MTHFR}

Methylenetetrahydrofolate reductase gene (MTHFR) polymorphism C677T is associated with hyperhomocysteinaemia as a result of reduced enzymatic activity ${ }^{15}$. Hyperhomocysteinemia 


\section{Chapter 1 Systematic Literature Review}

is associated with both arterial and venous thrombosis ${ }^{16,17}$. This pro-thrombotic effect may be due to the enhancement of factor V and XII (thrombotic factors) and repression of activated protein C (a thrombolytic factor) and also by directly influencing leukocyte-endothelial cell interactions $^{18,19}$. Carriage of the A1298C SNP protects against MTHFR C677T carriage by linkage disequilibrium and may therefore protect against thrombophilia ${ }^{20}$. It should be noted that compound heterozygosity (MTHFR C677T/A1298C) has a similar effect on homocysteine levels as homozygous C677T.

FVII

Carriage of factor VII (FVII) polymorphisms arg353gIn or FVII -323 10bp del/ins reduce the likelihood of thrombotic events by diminishing plasma levels of FVIIc ${ }^{21,22}$. Coagulation is mediated by FVII and tissue factor release in the event of extrinsic trauma.

FGB

Fibrinogen is cleaved to fibrin by thrombin, forming an abundant protein in blood clots. Carriage of the A allele at FGB -455 results in an increased level of fibrinogen in circulation and is associated with an increased incidence of thrombotic events e.g. in coronary artery disease ${ }^{23}$.

PAl-1

Plasminogen activator converts plasminogen to plasmin and is inhibited by plasminogen activator inhibitor 1 (PAI-1). Plasmin is active in breaking down fibrin within thromboses and reduced levels of PAI-1 are associated with thrombotic tendencies ${ }^{24}$. A -675 insertion/deletion SNP in the promoter region of PAI-1 is reported to alter PAI levels with 5 G (as opposed to $4 \mathrm{G}$ carriage) associated with reduced PAI-1 levels ${ }^{25}$. A further PAI-1 SNP has been described at 11053 but the functional role of this genotype remains to be elucidated ${ }^{26}$. 


\section{Chapter $1 \quad$ Systematic Literature Review}

\section{Endothelial protein C receptor}

Endothelial protein $\mathrm{C}$ binds activated endothelial protein $\mathrm{C}$ and enhances its activation. $\mathrm{A}$ A4600G SNP is thought to increase the levels of protein in circulation and has been associated with veinous thromboembolism ${ }^{27}$.

\section{Cerebral palsy association}

Thrombophilia has been associated with perinatal and paediatric stoke resulting in periventricular leukomalacia (PVL) and subsequent cerebral palsy outcome ${ }^{10,28}$. Thrombophilia is also associated with adverse pregnancy outcomes such as intrauterine growth restriction and preeclampsia, both risk factors of cerebral palsy ${ }^{29-33}$. Carriage of thrombophilic SNPs in either mother or child may therefore be associated with cerebral palsy outcome.

\section{Studies to date}

The majority of publications associating thrombophilic SNPs with cerebral palsy outcome are case reports or case studies (7/14). A number of other studies excluded from this review report thrombophilic SNP carriage with perinatal or paediatric cerebrovascular events but no specific cerebral palsy diagnosis was reported ${ }^{34,35}$. A review of case reports has been published previously ${ }^{36}$.

Case studies

In a case-study of 55 subjects, Halliday et al. ${ }^{37}$ report that carriage of FVL in patients with spastic hemiplegia is not significant when compared with the expected SNP frequency in the Australian population ( $7.4 \%$ compared to $3.6 \%$, binomial test, one tailed $p=0.13$ ). Carriage of Prothrombin G20210A was also not significant (1.9\%, expected frequency not quoted). Carriage of either FVL or Prothrombin G20210A in patients with radiological evidence of ischaemia was significantly different from the expected population prevalence $(21 \%$, binomial test, one tailed $p=0.013$ ). This sub-group of patients was selected for analysis as thrombophilic mutations would be expected to occur more frequently in individuals where evidence of a cerebral vascular event 


\section{Chapter 1 Systematic Literature Review}

was observed. Outcomes of this study were limited as no controls were tested and ethnicity of the cohort was not reported.

Senbil et al. ${ }^{38}$ report a $21.7 \%$ carriage of FVL and $8.7 \%$ carriage of Prothrombin G20210A in 23 cases of hemiplegia in Turkey. The significance of this finding is unknown as there were no controls in the study and the expected population frequency of these mutations is not reported. Also noted was the prevalence of additional risk factors of possible sequelae of thrombotic events including infection. It is possible that both genetic and environmental risk factors may be required for the initiation of a thrombotic event.

Smith et al. ${ }^{39}$ report a population study examining thrombophilic SNPs in patients with hemiplegia. Heterozygous carriage of FVL was found in 2/27 (7.4\%) patients tested and deemed not significantly different from the estimated $3.4 \%$ incidence in the UK population. Prothrombin G20210A was not detected in the 27 cases tested. This study had limited statistical power and the ethnicity of the cohort is not reported.

\section{Case-control studies}

Fattal-Valevski et al. ${ }^{40}$ report the first case-control study investigating cerebral palsy and thrombophilic SNPs. A cohort of 49 spastic cerebral palsy patients was compared with 118 healthy controls in Israel. The participants of each group were matched for age and ethnicity with Ashkenazi Jews, non-Ashkenazi Jews, mixed Jews and Arabs represented. Cases with evidence of ischemic stroke or a family history of thromboses were excluded from this study. No significant association between carriage of FVL, MTHFR or Prothrombin polymorphisms and cerebral palsy was reported. Comparison of SNP carriage between severe and mild cases of cerebral palsy was also not significant. This small study suggested that SNPs associated with thrombophilia are unlikely to be associated with cerebral palsy of non-vascular origin. Other studies ${ }^{41}$ have reported a significant difference in FVL carriage between Jews and Arabs and as these ethnic groups are not distinguished in this study, results may be confounded. 


\section{Chapter 1 Systematic Literature Review}

The largest case-control study to date was conducted by Gibson et al. ${ }^{14} .443$ cases and 883 controls from an Australian Caucasian population were examined. Analysis was conducted by cerebral palsy type (diplegia, hemiplegia and quadriplegia), gestational age ( $<32$ weeks, 32-36 weeks and >36 weeks) and carriage of MTHFR C667T, MTHFR A1298C, Prothrombin G20210A and FVL. Significant associations $(p<0.05)$ were seen for homozygous MTHFR C677T, 32-36 weeks gestational age and any cerebral palsy type, odds ratio $2.55,95 \%$ confidence interval 1.12-5.74; and homozygous MTHFR C677T, <32 weeks gestational age and diplegia, odds ratio $2.76,95 \%$ confidence interval 1.21-6.12. While not specifically thrombophilic, heterozygous MTHFR C677T was associated with cerebral palsy, 32-36 weeks gestational age and any cerebral palsy type, odds ratio $1.91,95 \%$ confidence interval 1.01-3.66, all gestational ages and diplegia odds ratio $1.58,95 \%$ confidence interval 1.02-2.45. MTHFR A1298C heterozygosity was protective for 32-36 weeks gestational age and diplegia, odds ratio $0.16,95 \%$ confidence interval 0.02-0.7. Homozygous FVL analysis with $<32$ weeks gestational age and quadriplegia gave an odds ratio of 9.12, 95\% confidence interval 0.86-53.71. Prothrombin G20210A heterozygosity and MTHFR C677T homozygosity were associated with all gestational ages and quadriplegia, odds ratio 5.33, 95\% confidence interval 1.06-23.25. No significance was seen in infants born at term with any SNP, demonstrating the importance of considering gestational age in the analysis. The results of this study are to be interpreted with caution due to the low numbers in each group, the number of sub-analyses conducted and the increased risk of type I error.

A further study examining the same cohort has also been published ${ }^{42}$. A significant association between endothelial cell receptor protein C and cerebral palsy $\geq 37$ weeks gestational age heterozygous versus normal odds ratio $1.5695 \%$ confidence interval $1.05-2.33, p=0.03$ is reported. Positive associations were not reported for the other thrombophilic SNPs examined. The caveats of previous studies are also true for this investigation. 
Chapter $1 \quad$ Systematic Literature Review

Nelson et al. ${ }^{43}$ examined 96 cases of cerebral palsy and 119 controls born at $\leq 32$ weeks

gestational age. Odds ratios are not reported, but significance was reported for heterozygous or homozygous FVII -323 10bp del/ins and FVII arg353gln and homozygous PAI-1 -11053 carriage. The authors also conduct a logistic regression to assess carriage of eNOS -922, FVII, LTA and PAI-1 -11053 simultaneously in non-Hispanic whites. Heterozygous carriage of eNOS (odds ratio 3.0, 95\% confidence interval 1.4-6.4), FVII (odds ratio 2.7, 95\% confidence interval 1.1-6.5), LTA (odds ratio $2.1,95 \%$ confidence interval $1.0-4.6$ ) and PAI-1 (odds ratio $3.2,95 \%$ confidence interval 1.28.7) were significantly associated with cerebral palsy outcome. Examination of Prothrombin G20210A, FVL, FGB -455, PAI-1 -675 and MTHFR C677T were not reported as significant in whites of either Hispanic or non-Hispanic origin. The authors express caution and caveats about their findings because of multiple sub-analyses and the risk of type I error.

Yehezkely-Schildkraut et al. ${ }^{41}$ compared 61 Israeli cases of spastic cerebral palsy not associated with infection, trauma or post neonatal acquisition with 62 controls. Ethnicity included Jews and Arabs. No significance was reported between cases and controls for FVL, Prothrombin G20210A or MTHFR C677T carriage. FVL carriage is reported to be significantly less in Jews than Arabs $(p=0.001)$ and the authors report that a significant association with cerebral palsy may have been masked by ethnic heterogeneity.

Reid et al. ${ }^{44}$ report 57 cases of cerebral palsy with imaging evidence of vascular thrombosis. The majority of these cases had hemiplegic cerebral palsy. Cases were compared with a control group of 167 cases of cerebral palsy without evidence of a thrombotic event. The study was conducted in Australia but ethnicity was not reported. This was the only case-control study to examine maternal and fetal genotypes. There was a significant difference in the frequency of FVL carriage between patients with cerebral palsy of thrombotic origin and the expected population frequency $(10.5 \%$ in the study group and $4 \%$ estimated for the population, $p=0.012$ ). Carriage of FVL in the control group of this study was $6.6 \%$, not significantly different 


\section{Chapter 1 Systematic Literature Review}

from the study group $(p=0.385)$. Carriage of $F V L$ in the maternal control group was also significantly different from the expected population frequency $(7.2 \%$ in the maternal control group and expected population frequency of $4 \%, p=0.036$ ). Maternal carriage of $F V L$ was not statistically different between the case and control groups of the study (case mothers $8.8 \%$, control mothers $7.2 \%, p=0.77)$. The results of this study remain to be confirmed with greater statistical power and comparison with non-cerebral palsy controls.

\section{Genetic-environmental interactions}

Risk factors within the fetus or infant may interact with a genetic predisposition to thrombotic events and influence cerebral palsy outcome. MTHFR is modulated by dietary intake of folate and vitamin B12 ${ }^{45}$ and this interaction may significantly alter the incidence of thrombotic events. Cytokines released during inflammation are reported to modulate the coagulation cascade, particularly in the fetal inflammatory response ${ }^{46}$. Formation of thromboses may hinder the spread of infection through the blood stream ${ }^{46}$. Inflammatory risk factors including viral or bacterial infection and genetic susceptibility to infection may contribute to a significant association between thrombophilic SNPs and cerebral palsy outcome. To date, no studies have reported on diet and few have reported on infection in combination with thrombophilic SNP carriage. One study did specifically exclude cerebral palsy cases reported to be the result of infection and this may explain why no significant association with thrombophilia was seen ${ }^{41}$.

Summary of association between hereditary thrombophilia and cerebral palsy

To date, most studies, except for that of Gibson et al., have been small or uncontrolled and often in mixed ethnic groups. This does not allow valid combination of their results. However, the case-control studies suggest that thrombophilic SNPs, particularly FVL and MTHFR C677T may be associated with cerebral palsy outcome. Cerebral palsy cases resulting from a thrombotic event are usually hemiplegic and show evidence of the event radiologically. Cerebral 


\section{Chapter 1 Systematic Literature Review}

palsy cases without evidence of a thrombovascular origin are unlikely to show a significant difference in thrombophilic SNP carriage when compared to either healthy patients or cases with evidence of a thrombovascular cause. Maternal carriage of thrombophilic SNPs may present a risk for cerebral palsy in the child and this requires further investigation. Significant differences in SNP carriage exists between ethnic groups and these differences are important to consider in study design. Gestational age and other risk factors such as infection may also be important. A case-control study with a large, ethnically homogenous sample comparing cerebral palsy cases of thrombotic origin with a non cerebral palsy control group is required to clarify these associations. 
Table 1

Studies examining SNPs associated with thrombophilic genes

\begin{tabular}{|c|c|c|c|c|c|c|c|c|c|c|c|c|}
\hline & & \multicolumn{2}{|c|}{ Cases } & \multirow{2}{*}{$\begin{array}{c}\begin{array}{c}\text { Comparison } \\
\text { group }\end{array} \\
\text { Number }\end{array}$} & \multirow[b]{2}{*}{$\begin{array}{l}\text { Inclusion/ } \\
\text { exclusion } \\
\text { criteria }\end{array}$} & \multirow[b]{2}{*}{ Other data recorded } & \multirow[b]{2}{*}{ Polymorphism } & \multirow[b]{2}{*}{ Comparison } & \multirow[b]{2}{*}{$\begin{array}{l}\text { Gestational } \\
\text { age (weeks) }\end{array}$} & \multirow[b]{2}{*}{$\begin{array}{l}\text { Degree } \\
\text { of risk }\end{array}$} & \multirow[b]{2}{*}{$\begin{array}{l}95 \% \mathrm{Cl}, \mathrm{P} \\
\text { value }\end{array}$} & \multirow[b]{2}{*}{ Reference } \\
\hline $\begin{array}{l}\text { Study area / } \\
\text { population }\end{array}$ & $\begin{array}{l}\text { Study } \\
\text { type }\end{array}$ & CP type & Number & & & & & & & & & \\
\hline $\begin{array}{l}\text { US, not } \\
\text { reported }\end{array}$ & $\begin{array}{l}\text { Case } \\
\text { report }\end{array}$ & Hemiplegia & 1 & - & - & $\begin{array}{l}\text { Heterozygous. Family history } \\
\text { of thrombotic events. Other } 2 \\
\text { cases not specifically } \\
\text { diagnosed with CP. }\end{array}$ & FVL & - & 40 & - & - & Thorarensen ${ }^{47}$ \\
\hline $\begin{array}{l}\text { US, not } \\
\text { reported }\end{array}$ & $\begin{array}{l}\text { Case } \\
\text { report }\end{array}$ & $\begin{array}{l}\text { Spastic } \\
\text { diplegia }\end{array}$ & 1 & & - & $\begin{array}{l}\text { Homozygous, severe acute } \\
\text { chorioamnionitis }\end{array}$ & FVL & - & 26 & - & - & Harum $^{48}$ \\
\hline \multirow[t]{3}{*}{$\begin{array}{l}\text { Australia, } \\
\text { not } \\
\text { reported }\end{array}$} & $\begin{array}{l}\text { Case } \\
\text { study }\end{array}$ & $\begin{array}{c}\text { Spastic } \\
\text { hemiplegia }\end{array}$ & 54 & $\begin{array}{l}\text { Reported } \\
\text { Australian } \\
\text { frequency } \\
\text { of FVL }\end{array}$ & - & & $\mathrm{FVL}$ & $\begin{array}{l}\text { Cp vs reported } \\
\text { Australian population } \\
\text { prevalence; }(4 / 54) \\
7.4 \% \text { vs } 3.6 \%\end{array}$ & Not reported & & $\begin{array}{c}\text { Binomial } \\
\text { test, one } \\
\text { tailed } p \\
\text { value } P=0.13\end{array}$ & Halliday ${ }^{37}$ \\
\hline & & $\begin{array}{c}\text { Spastic } \\
\text { hemiplegia }\end{array}$ & 52 & - & - & & $\begin{array}{l}\text { Prothrombin } \\
\text { G20 210A }\end{array}$ & (1/52) $1.9 \%$ & Not reported & & & Halliday ${ }^{37}$ \\
\hline & & $\begin{array}{c}\text { Spastic } \\
\text { hemiplegia }\end{array}$ & 14 & $\begin{array}{l}\text { Reported } \\
\text { Australian } \\
\text { frequency } \\
\text { of FVL }\end{array}$ & $\begin{array}{l}\text { Those with } \\
\text { radiological } \\
\text { evidence of } \\
\text { ischemia - } \\
\text { all others } \\
\text { excluded. }\end{array}$ & & $\begin{array}{l}\text { FVL or } \\
\text { Prothrombin } \\
\text { G20 210A }\end{array}$ & $\begin{array}{c}\text { Cp vs reported } \\
\text { Australian population } \\
\text { prevalence }(3 / 14) 21 \% \\
\text { vs } 3.6 \%\end{array}$ & Not reported & & $\begin{array}{l}\text { Binomial } \\
\text { test, one } \\
\text { tailed } \mathrm{p} \\
\text { value } \\
\mathrm{P}=0.013\end{array}$ & Halliday ${ }^{37}$ \\
\hline $\begin{array}{l}\text { US, not } \\
\text { recorded }\end{array}$ & $\begin{array}{l}\text { Case } \\
\text { report }\end{array}$ & $\begin{array}{c}\text { Spastic } \\
\text { quadriplegi } \\
\text { a }\end{array}$ & 1 & - & - & $\begin{array}{l}\text { Heterozygous. Strokes } \\
\text { occurred after orthopaedic } \\
\text { surgery. Heterozygous mother } \\
\text { and sister. }\end{array}$ & $\mathrm{FVL}$ & - & 41 & - & - & Steiner ${ }^{49}$ \\
\hline $\begin{array}{l}\text { US, not } \\
\text { recorded. }\end{array}$ & $\begin{array}{l}\text { Case } \\
\text { report }\end{array}$ & $\begin{array}{c}\text { Spastic } \\
\text { quadriplegi } \\
\text { a }\end{array}$ & 1 & - & - & $\begin{array}{l}\text { Multiple infarctions in } \\
\text { placenta, metabolic acidosis, } \\
\text { generalised seizures. }\end{array}$ & $\mathrm{FVL}^{*}$ & - & 37 & - & - & Lynch $^{36}$ \\
\hline
\end{tabular}




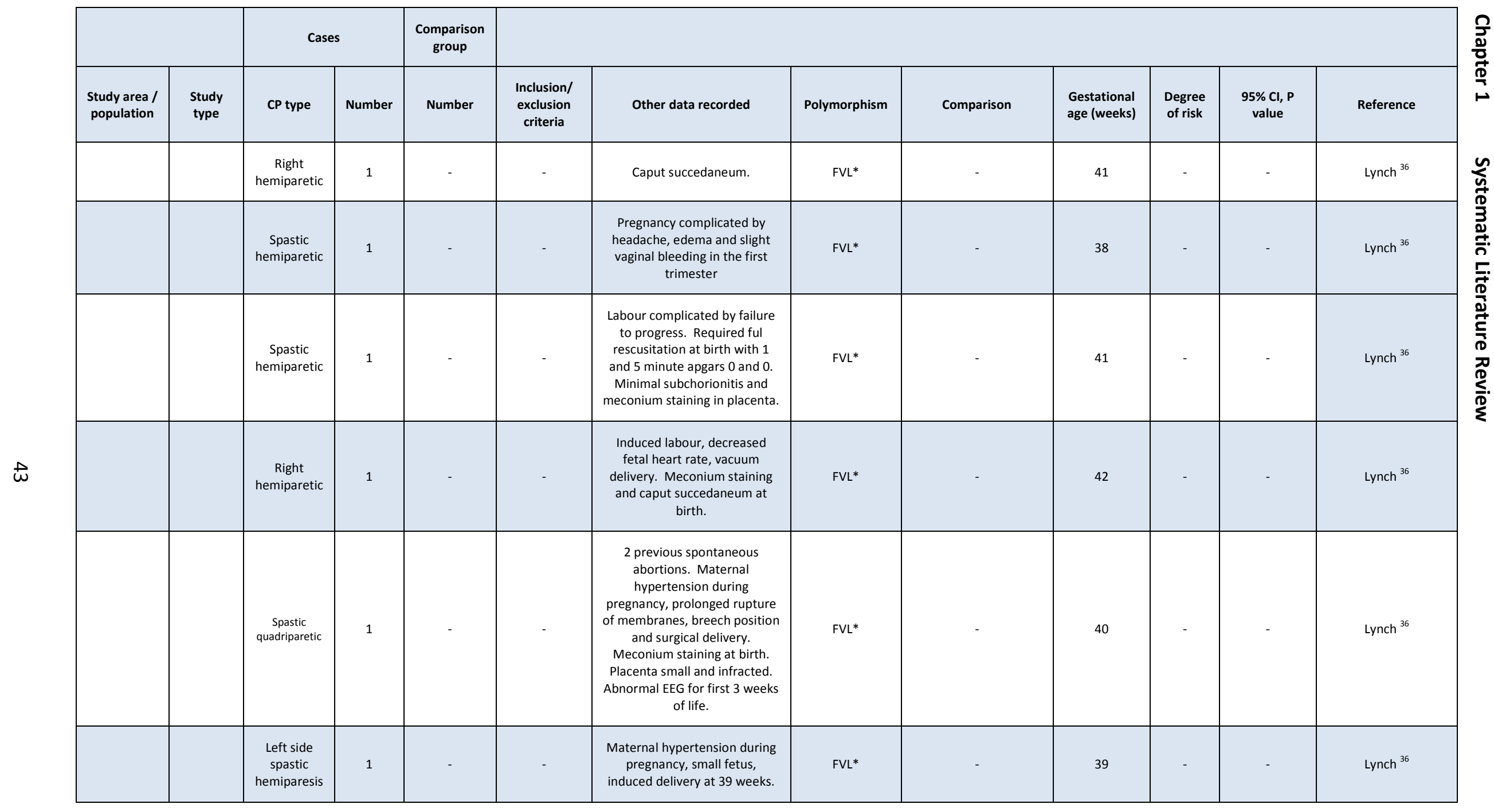




\begin{tabular}{|c|c|c|c|c|c|c|c|c|c|c|c|c|}
\hline \multirow[b]{2}{*}{$\begin{array}{l}\text { Study area / } \\
\text { population }\end{array}$} & \multirow[b]{2}{*}{$\begin{array}{l}\text { Study } \\
\text { type }\end{array}$} & \multicolumn{2}{|c|}{ Cases } & \multirow{2}{*}{$\begin{array}{c}\begin{array}{c}\text { Comparison } \\
\text { group }\end{array} \\
\text { Number }\end{array}$} & \multirow[b]{2}{*}{$\begin{array}{l}\text { Inclusion/ } \\
\text { exclusion } \\
\text { criteria }\end{array}$} & \multirow[b]{2}{*}{ Other data recorded } & \multirow[b]{2}{*}{ Polymorphism } & \multirow[b]{2}{*}{ Comparison } & \multirow[b]{2}{*}{$\begin{array}{l}\text { Gestational } \\
\text { age (weeks) }\end{array}$} & \multirow[b]{2}{*}{$\begin{array}{l}\text { Degree } \\
\text { of risk }\end{array}$} & \multirow[b]{2}{*}{$\begin{array}{l}95 \% \mathrm{Cl}, \mathrm{P} \\
\text { value }\end{array}$} & \multirow[b]{2}{*}{ Reference } \\
\hline & & CP type & Number & & & & & & & & & \\
\hline & & $\begin{array}{c}\text { Spastic } \\
\text { quadriparetic }\end{array}$ & 1 & - & - & $\begin{array}{l}\text { Preeclamptic mother, } \\
\text { decreased movements } 48 \\
\text { hours prior to delivery. } \\
\text { Anasarca at birth, moderate } \\
\text { bronchopulmonary dysplagia. } \\
\text { At } 2 \text { weeks developed increase } \\
\text { in head circumference and } \\
\text { bulging frontanels. Ventricular } \\
\text { taps performed until } 6 \text { weeks } \\
\text { of age. }\end{array}$ & $\mathrm{FVL}^{*}$ & - & 32 & - & - & Lynch $^{36}$ \\
\hline $\begin{array}{l}\text { UK, not } \\
\text { reported. }\end{array}$ & $\begin{array}{l}\text { Populatio } \\
\text { n case } \\
\text { study }\end{array}$ & Hemiplegic & $\begin{array}{l}38 \\
\text { identified, } \\
27 \\
\text { consented }\end{array}$ & - & - & & FVL & $\begin{array}{l}2 / 27(7.4 \%) . \\
\text { Equivalent to other } \\
\text { reported controls. }\end{array}$ & 29,40 & - & - & Smith ${ }^{39}$ \\
\hline & & Hemiplegic & $\begin{array}{c}38 \\
\text { identified, } \\
27 \\
\text { consented }\end{array}$ & - & - & & $\begin{array}{l}\text { Prothrombin } \\
\text { G20 210A }\end{array}$ & $0 / 27$ & - & - & - & Smith ${ }^{39}$ \\
\hline $\begin{array}{c}\text { Israel, } \\
\text { Ashkenazi } \\
\text { Jews, Non- } \\
\text { Ashkenazi } \\
\text { Jews, Mixed } \\
\text { Jews, Arabs }\end{array}$ & $\begin{array}{l}\text { Case- } \\
\text { control }\end{array}$ & Spastic & 49 & 118 & $\begin{array}{l}\text { Excluded all } \\
\text { CP of } \\
\text { ischemic } \\
\text { stroke origin } \\
\text { and } \\
\text { individuals } \\
\text { with a } \\
\text { familial } \\
\text { history of } \\
\text { thrombophil } \\
\text { ia. }\end{array}$ & $\begin{array}{l}\text { Also no significant differences } \\
\text { between genotype and } \\
\text { etiology. }\end{array}$ & $\mathrm{FVL}$ & $\begin{array}{c}\text { CP vs non CP } 4(8.2 \%) \\
\text { vs } 5(4.2 \%)\end{array}$ & $\begin{array}{l}86 \% \text { defined } \\
\text { as preterm }\end{array}$ & OR 2.00 & 0.51-7.82, & Fattal-Valevski ${ }^{40}$ \\
\hline & & & & & & & MTHFR C677T & $\begin{array}{c}\text { CP vs non CP } 9(18.4 \%) \\
\text { vs } 19(16 \%)\end{array}$ & $\begin{array}{l}86 \% \text { defined } \\
\text { as preterm }\end{array}$ & OR 1.17 & $0.49-2.81$ & Fattal-Valevski $i^{40}$ \\
\hline & & & & & & & $\begin{array}{l}\text { Prothrombin } \\
\text { G20210A }\end{array}$ & $\begin{array}{c}\text { CP vs non CP } 1(2 \%) \text { vs } \\
3(2.5 \%)\end{array}$ & $\begin{array}{l}86 \% \text { defined } \\
\text { as preterm }\end{array}$ & OR 0.79 & $0.08-7.87$ & Fattal-Valevski $i^{40}$ \\
\hline & & & & & & & $\begin{array}{l}\text { FVL, MTHFR } \\
\text { C677T or } \\
\text { Prothrombin } \\
\text { G20210A }\end{array}$ & $\begin{array}{c}\text { CP vs non CP } \\
12(24.5 \%) \text { vs } 27 \\
(22.9 \%)\end{array}$ & $\begin{array}{l}86 \% \text { defined } \\
\text { as preterm }\end{array}$ & OR 1.09 & $0.5-2.38$ & Fattal-Valevski ${ }^{40}$ \\
\hline
\end{tabular}




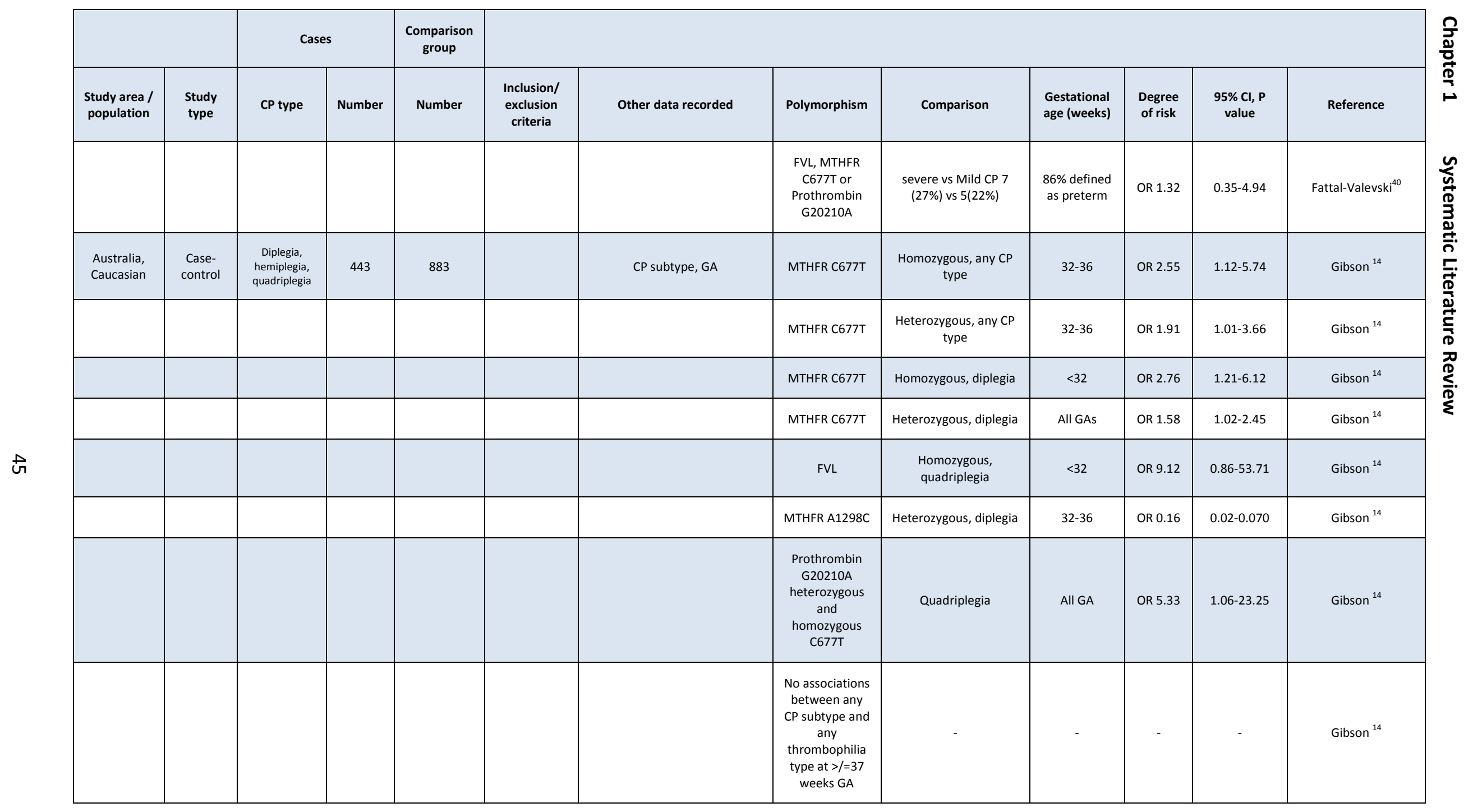




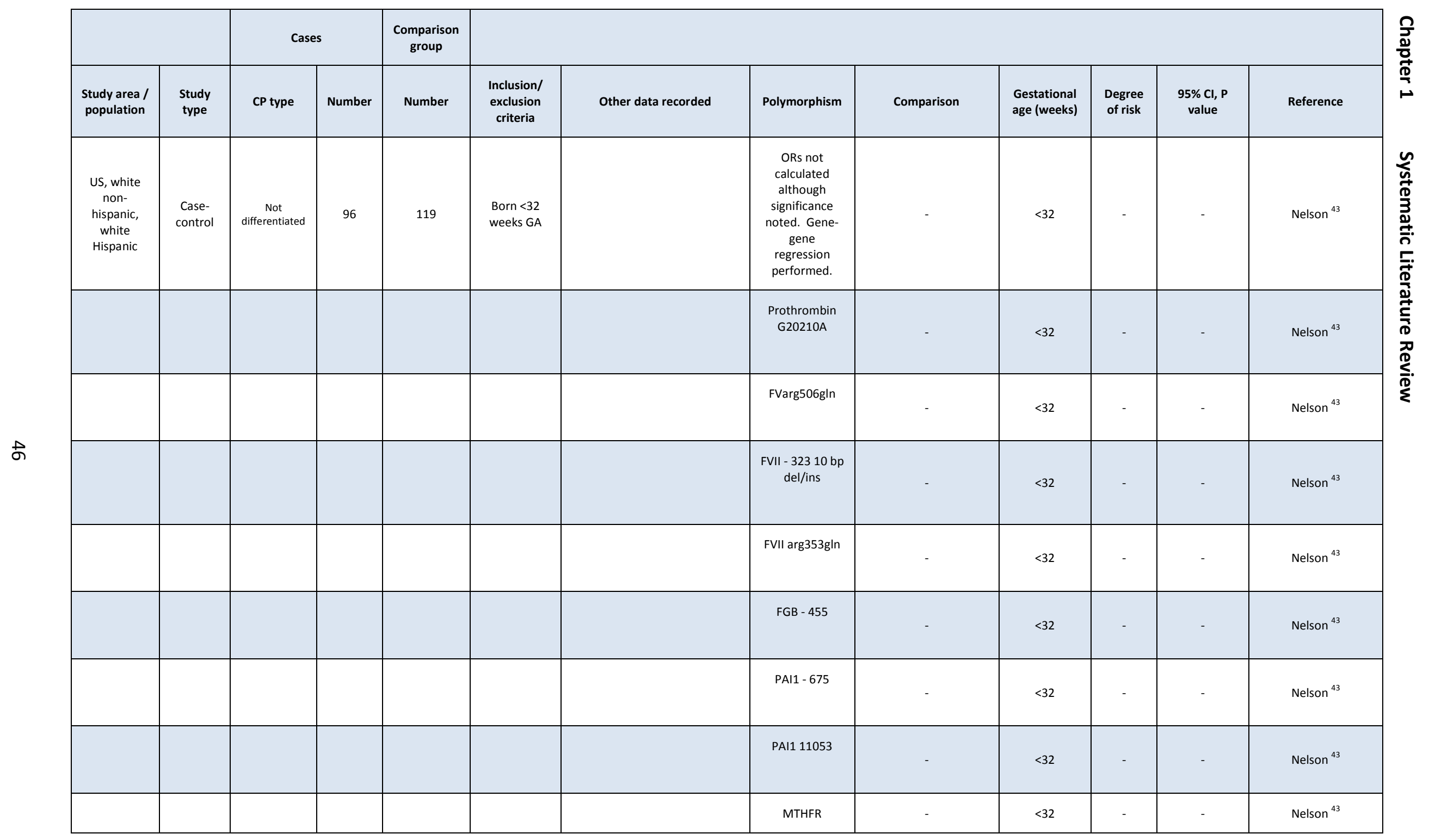




\begin{tabular}{|c|c|c|c|c|c|c|c|c|c|c|c|c|}
\hline & & \multicolumn{2}{|c|}{ Cases } & \multirow{2}{*}{$\begin{array}{c}\begin{array}{c}\text { Comparison } \\
\text { group }\end{array} \\
\text { Number }\end{array}$} & \multirow[b]{2}{*}{$\begin{array}{l}\text { Inclusion/ } \\
\text { exclusion } \\
\text { criteria }\end{array}$} & \multirow[b]{2}{*}{ Other data recorded } & \multirow[b]{2}{*}{ Polymorphism } & \multirow[b]{2}{*}{ Comparison } & \multirow[b]{2}{*}{$\begin{array}{l}\text { Gestational } \\
\text { age (weeks) }\end{array}$} & \multirow[b]{2}{*}{$\begin{array}{l}\text { Degree } \\
\text { of risk }\end{array}$} & \multirow[b]{2}{*}{$\begin{array}{l}95 \% \mathrm{Cl}, \mathrm{P} \\
\text { value }\end{array}$} & \multirow[b]{2}{*}{ Reference } \\
\hline $\begin{array}{l}\text { Study area / } \\
\text { population }\end{array}$ & $\begin{array}{l}\text { Study } \\
\text { type }\end{array}$ & CP type & Number & & & & & & & & & \\
\hline $\begin{array}{l}\text { Israel, } \\
\text { Jewish and } \\
\text { Arab }\end{array}$ & $\begin{array}{l}\text { Case - } \\
\text { control }\end{array}$ & Spastic CP & 61 & 62 & $\begin{array}{l}\mathrm{CP} \text { as a } \\
\text { result of } \\
\text { infection, } \\
\text { trauma or } \\
\text { adverse } \\
\text { events after } \\
\text { the neonatal } \\
\text { period are } \\
\text { excluded. }\end{array}$ & $\begin{array}{l}\text { Carriage of FVL is substantially } \\
\text { higher in Arabs that Jews } \\
\qquad(p=0.001)\end{array}$ & $\begin{array}{c}\text { FVL } \\
\text { heterozygous }\end{array}$ & CP vs Control & $\begin{array}{l}36 \% \text { of } \\
\text { whole } \\
\text { cohort } \\
\text { premature }\end{array}$ & & & $\begin{array}{l}\text { Yehezkely- } \\
\text { Schildkraut }{ }^{41}\end{array}$ \\
\hline & & & & & & & $\begin{array}{c}\text { FVL } \\
\text { homozygous }\end{array}$ & CP vs Control & $\begin{array}{c}36 \% \text { of } \\
\text { whole } \\
\text { cohort } \\
\text { premature }\end{array}$ & - & - & $\begin{array}{l}\text { Yehezkely- } \\
\text { Schildkraut }{ }^{41}\end{array}$ \\
\hline & & & & & & & MTHFR (C677T) & CP vs Control & $\begin{array}{c}36 \% \text { of } \\
\text { whole } \\
\text { cohort } \\
\text { premature }\end{array}$ & - & - & $\begin{array}{l}\text { Yehezkely- } \\
\text { Schildkraut }{ }^{41}\end{array}$ \\
\hline & & & & & & & $\begin{array}{l}\text { Prothrombin } \\
\text { G20210A }\end{array}$ & CP vs Control & $\begin{array}{l}36 \% \text { of } \\
\text { whole } \\
\text { cohort } \\
\text { premature }\end{array}$ & - & - & $\begin{array}{l}\text { Yehezkely- } \\
\text { Schildkraut }{ }^{41}\end{array}$ \\
\hline & & & & & & & $\begin{array}{c}\text { Any } \\
\text { thrombophilic } \\
\text { mutation }\end{array}$ & & $\begin{array}{c}36 \% \text { of } \\
\text { whole } \\
\text { cohort } \\
\text { premature }\end{array}$ & - & - & $\begin{array}{l}\text { Yehezkely- } \\
\text { Schildkraut }{ }^{41}\end{array}$ \\
\hline $\begin{array}{l}\text { Australian, } \\
\text { not } \\
\text { reported }\end{array}$ & $\begin{array}{c}\text { Case- } \\
\text { control }\end{array}$ & & 57 & 167 & $\begin{array}{l}\text { Those with } \\
\text { imaging } \\
\text { evidence of } \\
\text { vascular } \\
\text { thrombosis } \\
\text { compared to } \\
\text { those with } \\
\text { no imaging } \\
\text { finds. }\end{array}$ & $\begin{array}{l}\text { Study group predominantly } \\
\text { spastic hemiplegia, control } \\
\text { group more representative of } \\
\text { all CP subtypes. }\end{array}$ & FVL & $\begin{array}{l}\text { Thrombotic CP vs } \\
\text { other CP }\end{array}$ & Not reported & $\begin{array}{l}6 / 57 \\
(10.53 \%) \\
\text { vs } 11 / 167 \\
(6.59 \%)\end{array}$ & $P=0.385$ & Reid $^{44}$ \\
\hline
\end{tabular}




\begin{tabular}{|c|c|c|c|c|c|c|c|c|c|c|c|c|c|}
\hline \multirow{8}{*}{$\infty$} & & & \multicolumn{2}{|c|}{ Cases } & \multirow{2}{*}{\begin{tabular}{|c|}
$\begin{array}{c}\text { Comparison } \\
\text { group }\end{array}$ \\
Number
\end{tabular}} & \multirow[b]{2}{*}{$\begin{array}{l}\text { Inclusion/ } \\
\text { exclusion } \\
\text { criteria }\end{array}$} & \multirow[b]{2}{*}{ Other data recorded } & \multirow[b]{2}{*}{ Polymorphism } & \multirow[b]{2}{*}{ Comparison } & \multirow[b]{2}{*}{$\begin{array}{l}\text { Gestational } \\
\text { age (weeks) }\end{array}$} & \multirow[b]{2}{*}{$\begin{array}{l}\text { Degree } \\
\text { of risk }\end{array}$} & \multirow[b]{2}{*}{$\begin{array}{l}95 \% \mathrm{Cl}, \mathrm{P} \\
\text { value }\end{array}$} & \multirow[b]{2}{*}{ Reference } \\
\hline & $\begin{array}{l}\text { Study area / } \\
\text { population }\end{array}$ & $\begin{array}{l}\text { Study } \\
\text { type }\end{array}$ & CP type & Number & & & & & & & & & \\
\hline & & & & & & & & Maternal FVL & $\begin{array}{c}\text { Thrombotic CP vs } \\
\text { other CP }\end{array}$ & Not reported & $\begin{array}{c}5 / 57 \\
(8.77 \%) \\
\text { vs } \\
12 / 167 \\
(7.19 \%)\end{array}$ & $\mathrm{P}=0.773$ & Reid ${ }^{44}$ \\
\hline & & & & & & & & & $\begin{array}{l}\text { Thrombotic CP vs } \\
\text { expected population } \\
\text { frequency }\end{array}$ & Not reported & $\begin{array}{l}10.5 \% \\
\text { vs } 4 \%\end{array}$ & $\begin{array}{c}0.026-0.185 \\
p=0.012\end{array}$ & Reid ${ }^{44}$ \\
\hline & & & & & & & & & $\begin{array}{l}\text { Non-thrombotic CP } \\
\text { mothers vs expected } \\
\text { population frequency }\end{array}$ & Not reported & $\begin{array}{c}7.2 \% \text { vs } \\
4 \%\end{array}$ & $\begin{array}{c}0.032-0.111 \\
p=0.036\end{array}$ & Reid ${ }^{44}$ \\
\hline & $\begin{array}{l}\text { Greece, not } \\
\text { reported }\end{array}$ & $\begin{array}{l}\text { Case } \\
\text { report }\end{array}$ & $\begin{array}{c}\text { Spastic } \\
\text { quadriplegic }\end{array}$ & 1 & - & - & $\begin{array}{l}1 \text { further case of "left spastic } \\
\text { hemiparesis" reported but not } \\
\text { specifically diagnosed as CP. } \\
\text { Acute gastroenteritis Shigella } \\
\text { flexneri infection at } 6 \text { months } \\
\text { of age. Mother positive to FVL, } \\
\text { father positive to MTHFR. }\end{array}$ & $\begin{array}{l}\text { FVL poitive, } \\
\text { MTHFR C667T } \\
\text { positive }\end{array}$ & - & 38 & - & - & Vagiakou $^{50}$ \\
\hline & $\begin{array}{l}\text { Turkey, not } \\
\text { reported }\end{array}$ & $\begin{array}{l}\text { Case } \\
\text { study }\end{array}$ & Hemiplegic & 23 & - & $\begin{array}{c}\text { Neuro- } \\
\text { imaging } \\
\text { performed } \\
\text { on all } \\
\text { patients. } \\
\text { Additional } \\
\text { thrombotic } \\
\text { risk factors } \\
\text { recorded, } \\
\text { particularly } \\
\text { infection } \\
\text { and } \\
\text { congenital } \\
\text { heart } \\
\text { disease. }\end{array}$ & & $\mathrm{FVL}$ & $5 / 23(21.7 \%)$ & 39 & - & - & Senbil ${ }^{38}$ \\
\hline & & & & & & & & $\begin{array}{l}\text { Prothrombin } \\
\text { G20210A }\end{array}$ & $2 / 23(8.7 \%)$ & $\begin{array}{l}3 / 23 \\
\text { reported as } \\
\text { premature }\end{array}$ & - & - & Senbil ${ }^{38}$ \\
\hline
\end{tabular}




\begin{tabular}{|c|c|c|c|c|c|c|c|c|c|c|c|c|}
\hline \multirow[b]{2}{*}{$\begin{array}{l}\text { Study area / } \\
\text { population }\end{array}$} & \multirow[b]{2}{*}{$\begin{array}{l}\text { Study } \\
\text { type }\end{array}$} & \multicolumn{2}{|c|}{ Cases } & \multirow{2}{*}{$\begin{array}{c}\begin{array}{c}\text { Comparison } \\
\text { group }\end{array} \\
\text { Number }\end{array}$} & \multirow[b]{2}{*}{$\begin{array}{l}\text { Inclusion/ } \\
\text { exclusion } \\
\text { criteria }\end{array}$} & \multirow[b]{2}{*}{ Other data recorded } & \multirow[b]{2}{*}{ Polymorphism } & \multirow[b]{2}{*}{ Comparison } & \multirow[b]{2}{*}{$\begin{array}{l}\text { Gestational } \\
\text { age (weeks) }\end{array}$} & \multirow[b]{2}{*}{$\begin{array}{c}\text { Degree } \\
\text { of risk }\end{array}$} & \multirow[b]{2}{*}{$\begin{array}{l}95 \% \mathrm{Cl}, \mathrm{P} \\
\text { value }\end{array}$} & \multirow[b]{2}{*}{ Reference } \\
\hline & & CP type & Number & & & & & & & & & \\
\hline \multirow[t]{4}{*}{$\begin{array}{l}\text { Australia } \\
\text { Caucasian }\end{array}$} & $\begin{array}{l}\text { Case- } \\
\text { Control }\end{array}$ & $\begin{array}{l}\text { Diplegia, } \\
\text { hemiplegia, } \\
\text { quadriplegia }\end{array}$ & 443 & 883 & & & EPCR & $\begin{array}{l}\text { All CP Types, } \\
\text { heterozygous vs } \\
\text { normal }\end{array}$ & $\geq 37$ & OR 1.56 & $\begin{array}{c}1.05-2.33 \\
p=0.03\end{array}$ & Gibson ${ }^{42}$ \\
\hline & & & & & & & & $\begin{array}{l}\text { Diplegia, heterozygous } \\
\text { vs normal }\end{array}$ & All GAs & OR 1.92 & $\begin{array}{c}1.18-3.13 \\
p=0.008\end{array}$ & Gibson $^{42}$ \\
\hline & & & & & & & & $\begin{array}{c}\text { Diplegia, } \\
\text { homozygous/heterozy } \\
\text { gous vs normal }\end{array}$ & All GAs & OR 1.81 & $\begin{array}{c}1.13-2.91 \\
p=0.01\end{array}$ & Gibson ${ }^{42}$ \\
\hline & & & & & & & MTHFR & $\begin{array}{l}\text { Girls, all CP types, } \\
\text { heterozygous vs } \\
\text { normal }\end{array}$ & All GAs & OR 1.74 & $\begin{array}{c}1.15-2.64 \\
p=0.009\end{array}$ & Gibson ${ }^{42}$ \\
\hline & & & & & & & & $\begin{array}{l}\text { Girls, all CP types, } \\
\text { homozygous/heterozy } \\
\text { gous vs normal }\end{array}$ & All GAs & OR 1.63 & $\begin{array}{l}1.10-2.42 \\
p=0.02\end{array}$ & Gibson $^{42}$ \\
\hline & & & & & & & PAl-1_1 & $\begin{array}{c}\text { Girls, all CP types, } \\
\text { homozygous vs normal }\end{array}$ & All GAs & OR 1.92 & 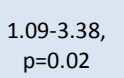 & Gibson $^{42}$ \\
\hline & & & & & & & & $\begin{array}{l}\text { Girls, all CP types, } \\
\text { homozygous/heterozy } \\
\text { gous vs normal }\end{array}$ & All GAs & OR 1.66 & $\begin{array}{c}\text { 1.04-2.64, } \\
p=0.03\end{array}$ & Gibson ${ }^{42}$ \\
\hline
\end{tabular}

${ }^{*}$ FVL translational products elevated in fetal blood presumably as a result of FVL mutation carriage. 


\section{Chapter 1}

\section{Systematic Literature Review}

\section{SNPs associated with the APOE gene}

Three alleles $(\varepsilon 2, \varepsilon 3, \varepsilon 4)$ of the Apolipoprotein E gene (APOE) have been investigated in association with cerebral palsy in three studies.

\section{Physiology of APOE SNPs and cerebral palsy association}

Apolipoprotein $\mathrm{E}$ is a lipid transport protein expressed abundantly in the central nervous system. Three isoforms of the Apolipoprotein E protein (E2, E3 and E4) correlate with three alleles of the gene $(\varepsilon 2, \varepsilon 3, \varepsilon 4)$. Carriage of the $\varepsilon 4$ allele has been associated with risk of developing Alzheimer disease ${ }^{51}$, ischemic stroke ${ }^{52}$ and poor recovery after central nervous system trauma ${ }^{52}$. Cerebral palsy can be considered the outcome of an antenatal or perinatal central nervous system injury and could potentially be associated with APOE SNP carriage.

\section{Studies to date}

\section{Case-control}

Meirelles et al. ${ }^{53}$ report a small case-control study examining 40 cerebral palsy patients and 40 gender matched controls in Brazil. All cerebral palsy cases had no reported cause, were the result of a normal pregnancy (including no maternal use of noxious substances, tobacco excepted) and were not the result of a genetic syndrome or central nervous system trauma. Ethnicity of the two cohorts was not reported. APOE $\varepsilon 4$ was significantly associated with cerebral palsy outcome, odds ratio $4.33,(95 \%$ confidence interval not reported). There was no association with APOE $\varepsilon 3$ or APOE $\varepsilon 2$, odds ratio 0.49 (95\% confidence interval not reported) and 1.0 (95\% confidence interval not reported), respectively.

Kuroda et al. ${ }^{54}$ report a larger case-control study examining 209 cases of congenital cerebral palsy. Choreoathetotic and ataxic forms of cerebral palsy and those the result of a genetic disorder or cytomegalovirus (CMV) were excluded. Cases and controls were matched by gender and race and included white, black and Hispanic Americans. A significant association was seen between APOE $\varepsilon 4$ and cerebral palsy (quadriplegia/triplegia vs controls, odds ratio 5.5, 95\% 


\section{Chapter 1 Systematic Literature Review}

confidence interval 1.2-35.9, $\mathrm{p}=0.022$, all subtypes vs controls odds ratio $3.4,95 \%$ confidence interval 1.4-8.7, $\mathrm{p}=0.003$ ), APOE $\varepsilon 2$ and cerebral palsy (all subtypes vs controls, odds ratio 12.0, 95\% confidence interval 1.6-247.2, $p=0.003)$. APOE $\varepsilon 4$ was also associated with an increased severity of cerebral palsy.

A further paper by McMichael et al. ${ }^{55}$ tested APOE genotype in 443 cases of cerebral palsy and 883 controls, all of Caucasian origin. Analysis by gestational age (all gestational ages, $<32$ weeks, 32-36 weeks and $\geq 37$ weeks), cerebral palsy type (all types, diplegia, hemiplegia and quadriplegia) and the presence or absence of viral nucleic acid on Guthrie cards showed no association between APOE $\varepsilon 4$ carriage and cerebral palsy. No association is reported between APOE $\varepsilon 2$ carriage and cerebral palsy; however the low frequency of the $\varepsilon 2$ allele in the cohort gave the results limited statistical power. Again, results from this cohort must be interpreted cautiously due to the multiple analyses conducted and the risk of type I error along with the small numbers in subgroups and the risk of type II error.

\section{Summary of association between APOE and cerebral palsy}

There appears to be no association of APOE $\varepsilon 4$ with cerebral palsy is Caucasians, though the reported differences in allele carriage between ethnic groups ${ }^{56}$ may explain why some investigators have reported an association in other ethnic groups. The role of APOE $\varepsilon 2$ remains controversial but could be clarified with a large case-control study of ethnically homogenous cohorts. 
Table 2

Studies examining SNPs associated with the APOE gene

\begin{tabular}{|c|c|c|c|c|c|c|c|c|c|c|c|c|}
\hline \multirow[b]{2}{*}{$\begin{array}{c}\text { Study area } \\
/ \\
\text { population }\end{array}$} & \multirow[b]{2}{*}{$\begin{array}{l}\text { Study } \\
\text { type }\end{array}$} & \multicolumn{2}{|l|}{ Cases } & \multirow{2}{*}{$\begin{array}{c}\begin{array}{c}\text { Comparison } \\
\text { group }\end{array} \\
\text { Number }\end{array}$} & \multirow[b]{2}{*}{$\begin{array}{l}\text { Inclusion/ } \\
\text { exclusion } \\
\text { criteria }\end{array}$} & \multirow[b]{2}{*}{$\begin{array}{l}\text { Other data } \\
\text { recorded }\end{array}$} & \multirow[b]{2}{*}{ Polymorphism } & \multirow[b]{2}{*}{ Comparison } & \multirow[b]{2}{*}{$\begin{array}{c}\text { Gestational } \\
\text { age } \\
\text { (weeks) }\end{array}$} & \multirow[b]{2}{*}{$\begin{array}{c}\text { Degree of } \\
\text { risk }\end{array}$} & \multirow[b]{2}{*}{$\begin{array}{l}95 \% \mathrm{Cl}, \mathrm{P} \\
\text { value }\end{array}$} & \multirow[b]{2}{*}{ Reference } \\
\hline & & CP type & Number & & & & & & & & & \\
\hline \multirow[t]{3}{*}{$\begin{array}{l}\text { Brazil, not } \\
\text { reported }\end{array}$} & $\begin{array}{l}\text { Case- } \\
\text { control }\end{array}$ & $\begin{array}{l}\text { Without established } \\
\text { cause }\end{array}$ & 40 & 40 & $\begin{array}{l}\text { No genetic } \\
\text { syndrome or } \\
\text { post neonatal } \\
\text { incident, no } \\
\text { toxic substance } \\
\text { use by mothers } \\
\text { during } \\
\text { pregnancy (did } \\
\text { not include } \\
\text { tobacco) }\end{array}$ & & APOE 4 & CP vs control & $\begin{array}{c}\text { Not } \\
\text { Reported }\end{array}$ & OR 4.333 & $<0.05$ & $\begin{array}{l}\text { Meirelles Kalil Pessoa de } \\
\text { Barros }^{53}\end{array}$ \\
\hline & & & & & & & APOE 3 & CP vs control & $\begin{array}{l}\text { Not } \\
\text { Reported }\end{array}$ & OR 0.49 & - & $\begin{array}{l}\text { Meirelles Kalil Pessoa de } \\
\text { Barros }^{53}\end{array}$ \\
\hline & & & & & & & APOE2 & CP vs control & $\begin{array}{l}\text { Not } \\
\text { Reported }\end{array}$ & OR1 & - & $\begin{array}{c}\text { Meirelles Kalil Pessoa de } \\
\text { Barros }^{53}\end{array}$ \\
\hline \multirow[t]{2}{*}{$\begin{array}{l}\text { US, White, } \\
\text { black, } \\
\text { Hispanic, } \\
\text { other }\end{array}$} & $\begin{array}{l}\text { Case- } \\
\text { control }\end{array}$ & $\begin{array}{l}\text { Congenital spastic - } \\
\text { quadriplegia/triplegia, } \\
\text { diplegia, hemiplegia }\end{array}$ & 209 & 209 & $\begin{array}{l}\text { Choreoathetotic } \\
\text { and ataxic } \\
\text { forms of CP } \\
\text { excluded. Also } \\
\text { exclude post } \\
\text { neonatal CP, } \\
\text { genetic } \\
\text { disorders and } \\
\text { congenital CMV } \\
\text { infection. }\end{array}$ & $\begin{array}{l}\text { Results } \\
\text { independent } \\
\text { of birth } \\
\text { weight }\end{array}$ & APOE E4 & $\begin{array}{l}\text { quadriplegia/triplegia } \\
\text { vs controls }\end{array}$ & $\begin{array}{c}\text { CP } \\
32.8 \pm 6.3 \\
\text { Non CP } \\
39.7 \pm 1.6\end{array}$ & OR 5.5 & $\begin{array}{l}1.2-35.9 \\
p=0.022\end{array}$ & Kuroda ${ }^{54}$ \\
\hline & & & & & & & APOE E4 & Diplegia vs controls & $\begin{array}{c}\text { CP } \\
32.8 \pm 6.3 \\
\text { Non CP } \\
39.7 \pm 1.6\end{array}$ & - & - & Kuroda $^{54}$ \\
\hline
\end{tabular}




\begin{tabular}{|c|c|c|c|c|c|c|c|c|c|c|c|c|}
\hline \multirow[b]{2}{*}{$\begin{array}{l}\text { Study area } \\
1 \\
\text { population }\end{array}$} & \multirow[b]{2}{*}{$\begin{array}{l}\text { Study } \\
\text { type }\end{array}$} & \multicolumn{2}{|l|}{ Cases } & \multirow{2}{*}{$\begin{array}{c}\begin{array}{c}\text { Comparison } \\
\text { group }\end{array} \\
\text { Number }\end{array}$} & \multirow[b]{2}{*}{$\begin{array}{l}\text { Inclusion/ } \\
\text { exclusion } \\
\text { criteria }\end{array}$} & \multirow[b]{2}{*}{$\begin{array}{l}\text { Other data } \\
\text { recorded }\end{array}$} & \multirow[b]{2}{*}{ Polymorphism } & \multirow[b]{2}{*}{ Comparison } & \multirow[b]{2}{*}{$\begin{array}{c}\text { Gestational } \\
\text { age } \\
\text { (weeks) }\end{array}$} & \multirow[b]{2}{*}{$\begin{array}{l}\text { Degree of } \\
\text { risk }\end{array}$} & \multirow[b]{2}{*}{$\begin{array}{l}95 \% \mathrm{Cl}, \mathrm{P} \\
\text { value }\end{array}$} & \multirow[b]{2}{*}{ Reference } \\
\hline & & CP type & Number & & & & & & & & & \\
\hline & & & & & & & APOE E4 & $\begin{array}{l}\text { Hemiplegia vs } \\
\text { controls }\end{array}$ & $\begin{array}{c}\text { CP } \\
32.8 \pm 6.3, \\
\text { Non CP } \\
39.7 \pm 1.6\end{array}$ & & & Kuroda ${ }^{54}$ \\
\hline & & & & & & & APOE E4 & $\begin{array}{l}\text { All subtypes vs } \\
\text { controls }\end{array}$ & $\begin{array}{c}\text { CP } \\
32.8 \pm 6.3, \\
\text { Non CP } \\
39.7 \pm 1.6\end{array}$ & OR 3.4 & $\begin{array}{l}1.4-8.7 \\
p=0.003\end{array}$ & Kuroda ${ }^{54}$ \\
\hline & & & & & & & APOE E2 & $\begin{array}{l}\text { quadriplegia/triplegia } \\
\text { vs controls }\end{array}$ & $\begin{array}{c}\text { CP } \\
32.8 \pm 6.3, \\
\text { Non CP } \\
39.7 \pm 1.6\end{array}$ & - & & Kuroda $^{54}$ \\
\hline & & & & & & & APOE E2 & Diplegia vs controls & $\begin{array}{c}C P \\
32.8 \pm 6.3, \\
\text { Non CP } \\
39.7 \pm 1.6\end{array}$ & - & - & Kuroda ${ }^{54}$ \\
\hline & & & & & & & APOE E2 & $\begin{array}{l}\text { Hemiplegia vs } \\
\text { controls }\end{array}$ & 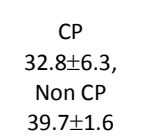 & - & - & Kuroda $^{54}$ \\
\hline & & & & & & & APOE E2 & $\begin{array}{l}\text { All subtypes vs } \\
\text { controls }\end{array}$ & $\begin{array}{c}\text { CP } \\
32.8 \pm 6.3, \\
\text { Non CP } \\
39.7 \pm 1.6\end{array}$ & OR 12.0 & $\begin{array}{c}\text { 1.6-247.2, } \\
p=0.003\end{array}$ & Kuroda 5 \\
\hline $\begin{array}{l}\text { Australia/ } \\
\text { Caucasian }\end{array}$ & $\begin{array}{l}\text { Case- } \\
\text { control }\end{array}$ & $\begin{array}{l}\text { Diplegia, hemiplegia, } \\
\text { quadriplegia }\end{array}$ & 443 & 883 & & $\begin{array}{l}\text { Gestational } \\
\text { ages, } \\
\text { evidence of } \\
\text { viral } \\
\text { exposure }\end{array}$ & $\begin{array}{c}\text { APOE E2/E3 vs } \\
\text { E3/E3 }\end{array}$ & $\begin{array}{l}\text { cerebral palsy vs } \\
\text { controls }\end{array}$ & $<32$ & OR 3.46 & $\begin{array}{c}1.12- \\
12.73 \\
p=0.031\end{array}$ & McMichael et a $1^{55}$ \\
\hline & & & & & & & APOE E2 & $\begin{array}{l}\text { Evidence of viral } \\
\text { exposure, cerebral } \\
\text { palsy, vs controls }\end{array}$ & $>37$ & OR 2.04 & $\begin{array}{l}\text { 1.04-3.98, } \\
p=0.035\end{array}$ & McMichael et a ${ }^{55}$ \\
\hline
\end{tabular}




\begin{tabular}{|c|c|c|c|c|c|c|c|c|c|c|c|c|}
\hline \multirow[b]{2}{*}{$\begin{array}{c}\text { Study area } \\
\text { population }\end{array}$} & \multirow[b]{2}{*}{$\begin{array}{c}\text { Study } \\
\text { type }\end{array}$} & \multicolumn{2}{|c|}{ Cases } & \multirow{2}{*}{$\begin{array}{c}\begin{array}{c}\text { Comparison } \\
\text { group }\end{array} \\
\text { Number }\end{array}$} & \multirow[b]{2}{*}{$\begin{array}{l}\text { Inclusion/ } \\
\text { exclusion } \\
\text { criteria }\end{array}$} & \multirow[b]{2}{*}{$\begin{array}{l}\text { Other data } \\
\text { recorded }\end{array}$} & \multirow[b]{2}{*}{ Polymorphism } & \multirow[b]{2}{*}{ Comparison } & \multirow[b]{2}{*}{$\begin{array}{c}\text { Gestational } \\
\text { age } \\
\text { (weeks) }\end{array}$} & \multirow[b]{2}{*}{$\begin{array}{l}\text { Degree of } \\
\text { risk }\end{array}$} & \multirow[b]{2}{*}{$\begin{array}{l}95 \% \mathrm{Cl}, \mathrm{P} \\
\text { value }\end{array}$} & \multirow[b]{2}{*}{ Reference } \\
\hline & & CP type & Number & & & & & & & & & \\
\hline & & & & & & & APOE E2/E2 & $\begin{array}{l}\text { Evidence of viral } \\
\text { exposure, cerebral } \\
\text { palsy, vs controls }\end{array}$ & $>37$ & OR 5.31 & $\begin{array}{c}0.82- \\
56.92 \\
p=0.043\end{array}$ & McMichael et a $1^{55}$ \\
\hline
\end{tabular}




\section{Chapter 1 Systematic Literature Review}

\section{SNPs associated with cytokine genes}

Eight cytokine gene SNPs have been investigated for association with cerebral palsy outcome in five studies (IL-6 -174, LTA thr26asn, TNF -376, TNF -308, TNF -238, IL-10 -1082, IL-1B, IL-8).

\section{Physiology of cytokine SNPs}

Inflammation is an essential part of the body's innate immune response and is characterised by pain, heat, redness and swelling. These characteristics are initiated by the release of a plethora of cytokines, interleukins and other inflammatory mediators from tissue and local blood vessels in response to microbial invasion. The cytokine response is a major part of the fetal inflammatory response to infection or other inflammatory agents. Cytokines regulating inflammation may be either pro-inflammatory or anti-inflammatory. Inflammation provides a rapid, albeit non-specific, response to invading micro-organisms and helps to bring cells and molecules to the area that will suppress infection, create a physical barrier preventing further spread of infection and also create an environment nurturing repair of damage resulting from the infection.

\section{IL-6}

Interleukin 6 (IL-6) is a pro-inflammatory cytokine. A promoter region SNP at -174 has been observed with the $C$ allele associated with higher levels of circulating IL- $6{ }^{57}$. This SNP may be related to increased rates of sepsis in preterm infants although reports to date are inconsistent $^{58}$.

\section{LTA}

Lymphotoxin- $\alpha$ (LTA) is a pro-inflammatory cytokine. LTA thr26asn is associated with a two-fold increase of cell-adhesion molecules, including VCAM1 in vascular smooth-muscle cells of human coronary artery and with myocardial infarction (odds ratio $1.78, \chi^{2}=21.6, \mathrm{p}=$ $0.00000033)^{59}$. 


\section{Chapter 1 Systematic Literature Review}

$T N F-\alpha$

Tumour Necrosis Factor- $\alpha$ (TNF- $\alpha$ ) is a pro-inflammatory cytokine. The -308G SNP is associated with increased levels of TNF- $\alpha$ in circulation ${ }^{60}$ and may influence the outcome of infection ${ }^{61}$. SNPs at -376 and -238 are yet to be functionally characterised ${ }^{62}$.

IL-10

Interleukin 10 (IL-10) is an anti-inflammatory cytokine. Three promoter region SNPs have been described: $-1082 \mathrm{G} / \mathrm{A},-819 \mathrm{C} / \mathrm{T}$ and $-592 \mathrm{C} / \mathrm{A}$. These SNPs are preferentially associated as haplotypes GCC, ACC, and ATA (-1082, -819 and -592 , respectively) with high levels of IL-10 production ${ }^{63}$. The anti-inflammatory effects of IL-10 are mediated by reducing synthesis of proinflammatory cytokines ${ }^{64}$.

$I L-1 B$

Interleukin -1B (IL-1B) is a pro-inflammatory cytokine. $A+3953 \mathrm{C} / \mathrm{T}$ promoter SNP is associated with high levels of IL-B secretion in vitro ${ }^{65}$.

IL-8

Interleukin 8 (IL-8) is a proinflammatory cytokine. A A251T polymorphism has been described and is associated with asthma presumably through high IL-8 production ${ }^{66}$.

\section{Cerebral palsy association}

Pro-inflammatory cytokines may be neurotoxic and an increased level in circulation may damage the fetal central nervous system ${ }^{67}$. Cytokine release is a key aspect of chorioamnionitis and fetal inflammatory response syndrome. Cytokines may be released from the maternal or fetal immune system ${ }^{46}$. Both chorioamnionitis and fetal inflammatory response syndrome are associated with cerebral palsy outcome ${ }^{68} 69$. Reduced levels of cytokine release may result in a compromised immune system and allow bacteria or virus to proceed throughout the body unhindered. Some bacteria ${ }^{70}$ and viruses ${ }^{71}$ are reported to be neurotoxic and may damage the fetal central nervous system . 


\section{Chapter 1 Systematic Literature Review}

Studies to date

Case studies

In a longitudinal study of 148 infants born at $\leq 32$ weeks gestational age, Harding et al. ${ }^{72}$

examined cerebral palsy outcome in association with of IL-6 -174 carriage. Cerebral palsy was diagnosed in a subset of 11 children and incidence was compared between those carrying the CC allele $(4 / 27,15 \%)$ and those with CG or GG alleles $(9 / 121,7 \%$. odds ratio $2.2,95 \%$ confidence interval 0.6-7.6, $\mathrm{p}=0.22$ ). There was no significant association between IL-6 -174 and cerebral palsy in this cohort, though the small number of cases gives limited statistical power. In the whole cohort, significant associations with CC allele carriage were found for haemorrhagic brain injuries (CC 5/27 (19\%), CG/GG 7/121 (6\%), p=0.038; odds ratio 3.5, 95\% confidence interval 1.012.2 ), images consistent with white matter damage (CC 7/27 (26\%), CG/GG 9/121 (7\%), p=0.008; odds ratio 4.1, 95\% confidence interval 1.4-12.2), and other disabilities (CC 8/27 (30\%), CG/GG $16 / 121(13 \%), p=0.046$; odds ratio $2.8,95 \%$ confidence interval $1.04-7.4)$.

Dordelmann et al. ${ }^{73}$ in a study of 73 cases of children born at $<32$ weeks gestational age did not show a significant association between IL-10 -1082, IL-1B, or TNF- $\alpha-308$ and cerebral palsy. Cases examined were of mixed ethnicity and the sample size was too small to draw any conclusions.

\section{Case-control studies}

Nelson et al. ${ }^{43}$ examine 96 cases and 119 controls born at $<32$ weeks gestational age and report a significant association between cerebral palsy and LTA thr26asn $(p<0.05$ for distribution difference between all control children and all children with cerebral palsy and between nonHispanic control children and non-Hispanic children with cerebral palsy). No significance was reported for other cytokine SNPs including TNF- $\alpha-376,-308$ and -238 . Logistic regression was conducted to assess carriage of eNOS -922, FVII, LTA and PAI-1 -11053 simultaneously in nonHispanic whites. Heterozygous carriage of eNOS (odds ratio 3.0, Cl 1.4-6.4), FVII (odds ratio 2.7, 


\section{Chapter 1 Systematic Literature Review}

$\mathrm{Cl}$ 1.1-6.5), LTA (odds ratio 2.1, $\mathrm{Cl}$ 1.0-4.6) and PAI1 (odds ratio $3.2, \mathrm{Cl} 1.2-8.7$ ) were significantly associated with cerebral palsy outcome. This association remains to be confirmed by other investigators and with greater statistical power.

Gibson et al. ${ }^{5}$ report the largest case-control study examining cytokine SNPs and cerebral palsy association. 443 cases and 883 controls of Australian Caucasian origin were genotyped, showing a significant association between TNF- $\alpha-308$ (heterozygous or homozygous) in infants born at $<32$ weeks gestational age and later diagnosed with hemiplegic cerebral palsy (odds ratio $2.38,95 \%$ confidence interval 1.02-5.58). There was also significant association between carriage of TNF- $\alpha-308$ (heterozygous) and quadriplegia (odds ratio 1.82, 95\% confidence interval 1.043.15). Analysis of TNF- $\alpha-308$, MBL genotype and cerebral palsy outcome of any type also showed significance (odds ratio $1.37,95 \%$ confidence interval 1.02-1.84). Again, the authors add caveats about multiple analyses of subgroups with small numbers and the possibility of type I and II errors.

A further study by Gibson et $a .^{42}$ reports a positive association between IL-8 A251T and cerebral palsy ( $<37$ weeks gestational age homozygous versus normal odds ratio $2.37,95 \%$ confidence interval 1.26-4.43, $\mathrm{p}=0.007$; homozygous/heterozygous versus normal odds ratio 2.11, 95\% confidence interval 1.29-3.43, $\mathrm{p}=0.003$ ) and LTA thr26asn and cerebral palsy (all gestational ages, homozygous versus normal, odds ratio 1.49 95\% confidence interval 1.01-2.18, $p=0.04$ ). Caveats of previous studies by this group remain and should also be noted.

\section{Gene-Environment interactions}

Cytokines mediate the body's inflammatory response and are produced in response to viral or bacterial infection. The literature is currently lacking in studies examining cytokine polymorphisms in cerebral palsy cases associated with intrauterine infection or early life central nervous system inflammation. 


\section{Chapter 1 Systematic Literature Review}

Increased cytokine levels are reported in chorioamnionitis, a pregnancy condition associated with cerebral palsy outcome. Considering the ability of cytokines to cross the placenta

${ }^{74}$ and the association of intrauterine infection and chorioamnionitis with cerebral palsy ${ }^{68,75}$, it would be logical to examine maternal cytokine SNPs in the context of fetal cerebral palsy outcome. Cytokines are also reported to interact with the coagulation cascade ${ }^{76}$. One study to date has performed logistic regression analysis using an additive model for thrombophilic gene (FVII and PAI-1) and cytokine gene (LTA) SNPs and observed a significant association of simultaneous carriage with cerebral palsy outcome ${ }^{43}$, however further studies are required to establish this link.

\section{Summary of Association between Cytokine SNPs and Cerebral Palsy}

Significant associations between cerebral palsy outcome and cytokine SNPs have only been reported for TNF- $\alpha-308$ (in term and preterm infants) and LTA thr26asn (in preterm infants and infants of all gestational ages). These and other possible cytokine associations with cerebral palsy need to be tested in large, well powered studies with predetermined analyses of specified candidate genes and sub-group analyses by gestational age, cerebral palsy sub-type and environmental risk factors such as maternal infection. 
Table 3

Studies examining SNPs associated with cytokine genes.

\begin{tabular}{|c|c|c|c|c|c|c|c|c|c|c|c|c|}
\hline & & \multicolumn{2}{|c|}{ Cases } & \multirow{2}{*}{$\begin{array}{c}\begin{array}{c}\text { Comparison } \\
\text { group }\end{array} \\
\text { Number }\end{array}$} & \multirow[b]{2}{*}{$\begin{array}{l}\text { Inclusion/ } \\
\text { exclusion } \\
\text { criteria }\end{array}$} & \multirow[b]{2}{*}{$\begin{array}{l}\text { Other data } \\
\text { recorded }\end{array}$} & \multirow[b]{2}{*}{ Polymorphism } & \multirow[b]{2}{*}{ Comparison } & \multirow[b]{2}{*}{$\begin{array}{l}\text { Gestational } \\
\text { age (weeks) }\end{array}$} & \multirow[b]{2}{*}{ Degree of risk } & \multirow[b]{2}{*}{$\begin{array}{l}95 \% \mathrm{Cl}, \mathrm{P} \\
\text { value }\end{array}$} & \multirow[b]{2}{*}{ Reference } \\
\hline $\begin{array}{l}\text { Study area / } \\
\text { population }\end{array}$ & Study type & CP type & Number & & & & & & & & & \\
\hline UK, white & $\begin{array}{l}\text { Longitudinal } \\
\text { study, case } \\
\text { study }\end{array}$ & Not recorded & 11 & - & $\begin{array}{c}\text { Born } \leq 32 \mathrm{GA} \text {, } \\
\text { participated } \\
\text { in an early } \\
\text { education } \\
\text { program } \\
\text { focussed on } \\
\text { the child or } \\
\text { social } \\
\text { support. }\end{array}$ & $\begin{array}{l}\text { Perinatal and } \\
\text { family } \\
\text { characteristics } \\
\text { not } \\
\text { significantly } \\
\text { different. }\end{array}$ & $\begin{array}{l}\mathrm{IL}-6-174 \mathrm{CC} \\
\text { and } \mathrm{GC}+\mathrm{GG}\end{array}$ & $\begin{array}{c}\text { CP vs non CP CC - } 4(15 \%) \text {, } \\
\text { CG/GG - } 9(7 \%)\end{array}$ & $\leq 32$ & OR 2.2 & $\begin{array}{l}0.6-7.6 \\
P=0.224\end{array}$ & Harding ${ }^{72}$ \\
\hline \multirow[t]{4}{*}{$\begin{array}{l}\text { US, white non- } \\
\text { hispanic, } \\
\text { white Hispanic }\end{array}$} & $\begin{array}{l}\text { Case- } \\
\text { control }\end{array}$ & $\begin{array}{c}\text { Not } \\
\text { differentiated }\end{array}$ & 96 & 119 & $\begin{array}{l}\text { Born }<32 \\
\text { weeks GA }\end{array}$ & & $\begin{array}{l}\text { odds ratios } \\
\text { not calculated } \\
\text { although } \\
\text { significance } \\
\text { noted for the } \\
\text { following. } \\
\text { Gene-gene } \\
\text { logistic } \\
\text { regression } \\
\text { performed. }\end{array}$ & & $<32$ & & & Nelson ${ }^{43}$ \\
\hline & & & & & & & LTA thr26asn & & $<32$ & & & Nelson ${ }^{43}$ \\
\hline & & & & & & & TNF - 376 & & $<32$ & & & Nelson ${ }^{43}$ \\
\hline & & & & & & & TNF - 308 & & $<32$ & & & Nelson ${ }^{43}$ \\
\hline
\end{tabular}




\begin{tabular}{|c|c|c|c|c|c|c|c|c|c|c|c|c|}
\hline \multirow[b]{2}{*}{$\begin{array}{l}\text { Study area / } \\
\text { population }\end{array}$} & \multirow[b]{2}{*}{ Study type } & \multicolumn{2}{|c|}{ Cases } & \multirow{2}{*}{$\begin{array}{c}\begin{array}{c}\text { Comparison } \\
\text { group }\end{array} \\
\text { Number }\end{array}$} & \multirow[b]{2}{*}{$\begin{array}{c}\text { Inclusion/ } \\
\text { exclusion } \\
\text { criteria }\end{array}$} & \multirow[b]{2}{*}{$\begin{array}{l}\text { Other data } \\
\text { recorded }\end{array}$} & \multirow[b]{2}{*}{ Polymorphism } & \multirow[b]{2}{*}{ Comparison } & \multirow[b]{2}{*}{$\begin{array}{l}\text { Gestational } \\
\text { age (weeks) }\end{array}$} & \multirow[b]{2}{*}{ Degree of risk } & \multirow[b]{2}{*}{$\begin{array}{l}95 \% \mathrm{Cl}, \mathrm{P} \\
\text { value }\end{array}$} & \multirow[b]{2}{*}{ Reference } \\
\hline & & CP type & Number & & & & & & & & & \\
\hline & & & & & & & TNF - 238 & & $<32$ & & & Nelson ${ }^{43}$ \\
\hline \multirow{3}{*}{$\begin{array}{l}\text { Germany, } \\
\text { German, } \\
\text { Mediteranean, } \\
\text { African, Asian, } \\
\text { Hispanic, } \\
\text { Middle } \\
\text { Eastern }\end{array}$} & Case study & 73 & & & $\begin{array}{l}<32 \text { weeks } \\
\text { GA }\end{array}$ & & $\begin{array}{l}\text { IL-10 (-1082) } \\
\text { GG }\end{array}$ & $\begin{array}{l}\text { Insufficient numbers to } \\
\text { determine }\end{array}$ & $<32$ & - & - & $\underset{73}{\text { Dordelmann }}$ \\
\hline & & & & & & & IL-1B & $\begin{array}{l}\text { Insufficient numbers to } \\
\text { determine }\end{array}$ & $<32$ & - & - & $\begin{array}{l}\text { Dordelmann } \\
73\end{array}$ \\
\hline & & & & & & & TNF-a & $\begin{array}{l}\text { Insufficient numbers to } \\
\text { determine }\end{array}$ & $<32$ & - & - & $\begin{array}{l}\text { Dordelmann } \\
73\end{array}$ \\
\hline \multirow[t]{3}{*}{$\begin{array}{l}\text { Australian, } \\
\text { Caucasian }\end{array}$} & $\begin{array}{l}\text { Case - } \\
\text { control }\end{array}$ & $\begin{array}{c}\text { Diplegia, } \\
\text { hemiplegia, } \\
\text { quadriplegia }\end{array}$ & 443 & 883 & & & TNF-a -308 & $\begin{array}{l}\text { At term, heterozygous, } \\
\text { quadriplegia }\end{array}$ & Term & OR 1.82 & $1.04-3.15$ & Gibson $^{5}$ \\
\hline & & & & & & & TNF-a -308 & $\begin{array}{l}\text { homozygous or } \\
\text { heterozygous, hemiplegia }\end{array}$ & $<32$ & OR 2.38 & $1.02-5.58$ & Gibson $^{5}$ \\
\hline & & & & & & & $\begin{array}{l}\text { Any cytokine } \\
\text { polymorphism }\end{array}$ & Any CP subtype & & OR 1.37 & $1.02-1.84$ & Gibson $^{5}$ \\
\hline \multirow[t]{3}{*}{$\begin{array}{l}\text { Australia } \\
\text { Caucasian }\end{array}$} & $\begin{array}{l}\text { Case- } \\
\text { Control }\end{array}$ & $\begin{array}{c}\text { Diplegia, } \\
\text { hemiplegia, } \\
\text { quadriplegia }\end{array}$ & 443 & 883 & & & LTA & $\begin{array}{l}\text { All CP types, homozygous } \\
\text { vs normal }\end{array}$ & All GAs & OR 1.49 & $1.01-2.18$ & Gibson $^{42}$ \\
\hline & & & & & & & & $\begin{array}{l}\text { Hemiplegia, homozygous } \\
\text { vs normal }\end{array}$ & All GAs & OR 1.82 & $\begin{array}{c}1.02-3.23 \\
p=0.04\end{array}$ & \\
\hline & & & & & & & & $\begin{array}{l}\text { Quadriplegia, homozygous } \\
\text { vs normal }\end{array}$ & All GAs & OR 1.85 & $\begin{array}{c}\begin{array}{c}1.01-3.338 \\
p=0.05\end{array}\end{array}$ & \\
\hline
\end{tabular}




\begin{tabular}{|c|c|c|c|c|c|c|c|c|c|c|c|c|}
\hline \multirow[b]{2}{*}{$\begin{array}{l}\text { Study area / } \\
\text { population }\end{array}$} & \multirow[b]{2}{*}{ Study type } & \multicolumn{2}{|c|}{ Cases } & \multirow{2}{*}{$\begin{array}{c}\begin{array}{c}\text { Comparison } \\
\text { group }\end{array} \\
\text { Number }\end{array}$} & \multirow[b]{2}{*}{$\begin{array}{l}\text { Inclusion/ } \\
\text { exclusion } \\
\text { criteria }\end{array}$} & \multirow[b]{2}{*}{$\begin{array}{l}\text { Other data } \\
\text { recorded }\end{array}$} & \multirow[b]{2}{*}{ Polymorphism } & \multirow[b]{2}{*}{ Comparison } & \multirow[b]{2}{*}{$\begin{array}{l}\text { Gestational } \\
\text { age (weeks) }\end{array}$} & \multirow[b]{2}{*}{ Degree of risk } & \multirow[b]{2}{*}{$\begin{array}{c}95 \% \mathrm{Cl}, \mathrm{P} \\
\text { value }\end{array}$} & \multirow[b]{2}{*}{ Reference } \\
\hline & & CP type & Number & & & & & & & & & \\
\hline & & & & & & & & $\begin{array}{l}\text { Quadriplegia, } \\
\text { homozygous/heterozygous } \\
\text { vs normal }\end{array}$ & All GAs & OR 1.57 & $\begin{array}{c}\text { 1.04-2.38, } \\
p=0.03\end{array}$ & \\
\hline & & & & & & & IL-8 & $\begin{array}{l}\text { All CP, homozygous vs } \\
\text { normal }\end{array}$ & $<37$ & OR 2.37 & $\begin{array}{c}1.26-4.443, \\
p=0.007\end{array}$ & \\
\hline & & & & & & & & $\begin{array}{l}\text { All CP, } \\
\text { homozygous/heterozygous } \\
\text { vs normal }\end{array}$ & $<37$ & OR 2.11 & $\begin{array}{l}\text { 1.29-3.43, } \\
p=0.003\end{array}$ & \\
\hline & & & & & & & & $\begin{array}{l}\text { Diplegia, heterozygous vs } \\
\text { normal }\end{array}$ & All GAs & OR 1.92 & $\begin{array}{c}\begin{array}{c}1.18-3.13, \\
p=0.008\end{array} \\
\text { (n) }\end{array}$ & \\
\hline & & & & & & & & $\begin{array}{l}\text { Diplegia, } \\
\text { homozygous/heterozygous } \\
\text { vs normal }\end{array}$ & All GAs & OR 1.81 & $\begin{array}{c}1.13-2.91, \\
p=0.01\end{array}$ & \\
\hline
\end{tabular}




\section{Chapter $1 \quad$ Systematic Literature Review}

\section{Other SNPs}

Twenty-three SNPs of other genes have been investigated in association with cerebral palsy outcome in five studies (TLR-4 asp299gly, MBL codon-52, MBL codon-54, MBL codon-57, eNOS -922, eNOS -690, eNOS glu298asp, ADD1 gly460trp, ADRB2 gln27glu, AGT met235thr, AGRT1 -1166, GNB3 -825, ATGA2 -873, ITGB3 leu33pro, MMP3 -1171, NPPA -664, NPPA -2238, SCNN1A trp493ag, SCNN1A ala663thr, SELE ser128arg, SELE leu554phe, COX2 -765, PDE4D).

\section{Physiology of TLR-4 SNP}

Toll like receptors (TLRs) cross the cell membrane and bind to specific recognition patterns created by extra-cellular proteins on invading micro-organisms. Activation of these receptors by binding leads to NF-KB activation and subsequently an increase in the production of cytokines, chemokines and antimicrobial peptides ${ }^{77}$. A missense SNP of TLR-4 asp299gly affects the extracellular domain of the receptor and is associated with reduced LPS binding ${ }^{78}$.

\section{Cerebral palsy association}

Reduced TLR-4 activity may impair the immune response to bacterial infection. Bacteria ${ }^{70}$ may be neurotoxic and damage the fetal central nervous system.

\section{Study summary}

Dordelmann et al. ${ }^{73}$ examined TLR-4 asp299gly carriage with cerebral palsy outcome in infants born at $<32$ weeks gestational age. Sample size (73) limited the significance of their findings. A larger study is required to examine TLR-4 asp299gly carriage in cerebral palsy cases, possibly analysing those with a history of antenatal or perinatal bacterial infection.

\section{Physiology of MBL SNPs}

Mannose binding lectin (MBL) binds carbohydrates on the surface of microorganisms. It is activated by serine kinases MASP1 and 2 and then cleaves complement components $\mathrm{C} 2$ and $\mathrm{C} 4$ and generates $\mathrm{C} 3$ convertase ${ }^{79}$. A number of MBL SNPs have been documented including MBL codon-52 (-52 arginine to cystine substitution), MBL codon-54 (-54 glycine to aspartic acid 


\section{Chapter 1 Systematic Literature Review}

substitution) and MBL codon-57 (-57 glycine to glutamic acid substitution). MBL codon-54 and MBL codon-57 result in reduced binding between subunits and therefore reduced MBL function while MBL codon-52 decreases MBL stability ${ }^{5}$. MBL SNPs have a reported haplotype association, with each haplotype resulting in different functional levels of MBL. In decreasing order of functional MBL these haplotypes are HYPA, LYQA, LYPA, LXPA, HYPD, LYQC and LYPD where -550 designates $\mathrm{H} / \mathrm{L},-221 \mathrm{Y} / \mathrm{X}$ and $+4 \mathrm{P} / \mathrm{Q}^{806}$.

\section{Cerebral palsy association}

Decreased MBL function may reduce activation of the immune system in response to viral or bacterial infection. Both bacteria ${ }^{70}$ and virus ${ }^{71}$ are reported to be neurotoxic and may damage the fetal central nervous system.

\section{Study summary}

In a case-control study of 443 cerebral palsy patients and 883 controls of Australian Caucasian ethnicity, Gibson et al. ${ }^{5}$ describe an association between cerebral palsy and MBL SNPs. Homo- and heterozygous MBL-54 was associated with diplegia for all gestational ages (odds ratio 1.55, $95 \%$ confidence interval 1.03-2.32). Homo- or heterozygous MBL-54 was associated with diplegia in patients born at term (odds ratio $2.12,95 \%$ confidence interval $1.10-4.05$ ), and any exon-1 MBL SNP (MBL-52,-54,-57) was associated with diplegia in patients born at term (odds ratio $1.94,95 \%$ confidence interval 1.05-3.62). This study was significantly extended through examination of haplotype carriage ${ }^{6}$. LYPD was associated with cerebral palsy of all types born at all gestational ages (odds ratio $1.57,95 \%$ confidence interval 1.00-2.46). It was also significantly associated with all cerebral palsy types, <37 weeks gestational age (odds ratio $2.43,95 \%$ confidence interval 1.41-4.18), all types <32 weeks gestational age (odds ratio $2.54,95 \%$ confidence interval 1.34-4.76) and hemiplegia $<32$ weeks gestational age (odds ratio $4.48,95 \%$ confidence interval 1.55-12.65). HYPD was associated with quadriplegia at all gestational ages (odds ratio $3.47,95 \%$ confidence interval 1.41-8.31) and quadriplegia at $<32$ weeks gestational age (odds ratio $7.86,95 \%$ confidence interval $1.67-29.48$ ). These associations were reported to 


\section{Chapter 1 Systematic Literature Review}

remain true for individuals who tested positive to viral nucleic acid in the Guthrie card and were not statistically significant in those without evidence of viral nucleic acid. This paper highlights two important aspects of SNP associations with cerebral palsy; firstly, the impact of multiple gene combinations; and secondly, possible gene-environment interactions. It is to be noted that there was no 'dose-response' correlation between circulating MBL predicted by haplotype and cerebral palsy severity and also the increased risk of type I error due to multiple analyses.

\section{Physiology of COX2 -765 SNPs}

COX2 is an enzyme involved in regulation of prostaglandins, in particular as an intrinsic part of a pro-inflammatory response. The C allele of COX2 -765 is associated with reduced COX2 gene expression and prostaglandin synthesis ${ }^{81,82}$. The SNP is carried in $>25 \%$ of UK Caucasians 83.

\section{Cerebral palsy association}

Cerebral palsy outcome is associated with inflammatory events such as intrauterine infection and chorioamnionitis ${ }^{75} 68$. A reduction in pro-inflammatory regulators such as COX2 may decrease the level of inflammatory response, and as such impair the (innate) immune response to a pathogen and increase the possibility of cerebral palsy outcome.

\section{Study summary}

Harding et al. ${ }^{82}$ examined 17 patients with cerebral palsy from a cohort of 207 individuals born at $\leq 32$ weeks gestational age taking part in a longitudinal study. Within the total cohort, 139 individuals carried the GG genotype, 13 (9\%) of which were diagnosed with cerebral palsy, while 68 carried CC or CG alleles, $4(6 \%)$ of which had cerebral palsy. This report claims there is no significant association between cerebral palsy and COX2 SNPs $(p=0.59)$. As this study lacked statistical power, results could be clarified in a large casecontrol study particularly noting patients where an antenatal or neonatal inflammatory event was recorded. One would not expect the $C$ allele to influence cerebral palsy outcome if no 


\section{Chapter 1 Systematic Literature Review}

inflammatory event was initiated. Significant associations were seen between COX2 genotype and cognitive measures of development (e.g. general cognitive ability $\mathrm{C}$ allele mean, 94.3 (standard error of mean 2.2) vs GG 100.9 (standard error of mean 1.7), $\mathrm{p}=0.028$ ).

\section{Physiology of other SNPS}

eNOS -922, eNOS -690, eNOS glu298asp, NOS2A, ADD1 gly460trp, ADRB2 gln27glu, AGT met235thr, AGRT1 -1166, GNB3 -825, ATGA2 -873, ITGB3 leu33pro, MMP3 -1171, NPPA -664, NPPA -2238, SCNN1A trp493ag, SCNN1A ala663thr, SELE ser128arg, SELE leu554phe and PDE4D were largely taken from a SNP panel of cardiovascular associated polymorphisms. eNOS influences vascular tone particularly in the brain ${ }^{84}$ and may alter the response during infection, hypoxia or coagulation events. Others have been associated with hypertension disorders and/or have an unknown mechanistic association with cerebral palsy.

\section{Study summary}

In a case-control study of 96 children with cerebral palsy and 119 controls born at $\leq 32$ weeks, Nelson et al. ${ }^{43}$ showed a significant association between eNOS -922 and cerebral palsy. This association was also significant when analysed by logistic regression with PAI-1 and FVII in non-Hispanics (odds ratio 3.0, 95\% confidence interval 1.4-6.4). Significance for one ADBR2 gene is also reported in non-Hispanic children and is confirmed Gibson et al. ${ }^{42}$ in 413 Caucasians with cerebral palsy and 856 controls ( $<37$ weeks gestational age heterozygous versus normal, odds ratio $1.65,95 \%$ confidence interval $1.04-2.63, p=0.04)$. A significant association with cerebral palsy and a combination of multiple genes suggests the importance of gene-gene interactions. These tentative results need to be confirmed in larger studies and cohorts of similar ethnicity must be used if comparisons are to be made. A further study by Gibson et al. ${ }^{42}$ reports a significant association between NOS2A C231T heterozygous/homozygous carriage and cerebral palsy (odds ratio $1.2995 \%$ confidence interval $1.00-1.67, p=0.047$ ). The study examined 413 cases of cerebral palsy and 856 controls of Caucasian background. Again, the investigation included multiple analyses subjecting the results to increased type I error. 


\section{Chapter 1 Systematic Literature Review}

Summary of association between other SNPs and cerebral palsy

MBL SNP association with cerebral palsy has been reported for individual SNP and haplotype carriage. The haplotype data did not show a dose-response relationship between expected functional protein levels and cerebral palsy severity and further testing is required. Large case-control studies are needed to further investigate a possible association of cerebral palsy with carriage of TLR-4 asp299gly or COX2-765. The exploratory study of Nelson et al. ${ }^{43}$ recommend eNOS -922 (subsequently confirmed by Gibson et al. ${ }^{42}$ ) and ADBR2 (remains to be confirmed) for further investigation and the significance in non-Hispanics should be noted. 
Table 4

Studies examining other SNPs.

\begin{tabular}{|c|c|c|c|c|c|c|c|c|c|c|c|c|}
\hline & & \multicolumn{2}{|c|}{ Cases } & \multirow{2}{*}{$\begin{array}{c}\begin{array}{c}\text { Comparison } \\
\text { group }\end{array} \\
\text { Number }\end{array}$} & \multirow[b]{2}{*}{$\begin{array}{l}\text { Inclusion/ } \\
\text { exclusion } \\
\text { criteria }\end{array}$} & \multirow[b]{2}{*}{$\begin{array}{l}\text { Other data } \\
\text { recorded }\end{array}$} & \multirow[b]{2}{*}{ Polymorphism } & \multirow[b]{2}{*}{ Comparison } & \multirow[b]{2}{*}{$\begin{array}{l}\text { Gestational } \\
\text { age (weeks) }\end{array}$} & \multirow[b]{2}{*}{ Degree of risk } & \multirow[b]{2}{*}{$\begin{array}{l}95 \% \mathrm{Cl}, \mathrm{P} \\
\text { value }\end{array}$} & \multirow[b]{2}{*}{ Reference } \\
\hline $\begin{array}{l}\text { Study area / } \\
\text { population }\end{array}$ & Study type & CP type & Number & & & & & & & & & \\
\hline $\begin{array}{l}\text { Germany, } \\
\text { German, } \\
\text { Mediteranean, } \\
\text { African, Asian, } \\
\text { Hispanic, } \\
\text { Middle } \\
\text { Eastern }\end{array}$ & Case study & 73 & & & $\begin{array}{c}<32 \text { weeks } \\
\text { GA }\end{array}$ & & TLR-4 & $\begin{array}{l}\text { Insufficient numbers to } \\
\text { determine }\end{array}$ & - & - & - & $\underset{73}{\operatorname{Dordelmann}}$ \\
\hline \multirow[t]{3}{*}{$\begin{array}{l}\text { Australian, } \\
\text { Caucasian }\end{array}$} & $\begin{array}{l}\text { Case - } \\
\text { control }\end{array}$ & $\begin{array}{c}\text { Diplegia, } \\
\text { hemiplegia, } \\
\text { quadriplegia }\end{array}$ & 443 & 883 & & & MBL codon-54 & $\begin{array}{c}\text { homozygous or } \\
\text { heterozygous, diplegia }\end{array}$ & All GAs & OR 1.55 & $1.03-2.32$ & Gibson $^{5}$ \\
\hline & & & & & & & MBL codon-54 & $\begin{array}{c}\text { homozygous or } \\
\text { heterozygous, diplegia }\end{array}$ & Term & OR 2.12 & $1.10-4.05$ & Gibson $^{5}$ \\
\hline & & & & & & & $\begin{array}{c}\text { MBL exon-1 } \\
\text { (codon 52, 54, } \\
57 \text { or } \\
\text { abnormal) }\end{array}$ & $\begin{array}{l}\text { any polymorphism, } \\
\text { diplegia }\end{array}$ & Term & OR 1.94 & $1.05-3.62$ & Gibson $^{5}$ \\
\hline \multirow[t]{2}{*}{$\begin{array}{l}\text { US, white non- } \\
\text { hispanic, } \\
\text { white Hispanic }\end{array}$} & $\begin{array}{l}\text { Case- } \\
\text { control }\end{array}$ & $\begin{array}{c}\text { Not } \\
\text { differentiated }\end{array}$ & 96 & 119 & $\begin{array}{l}\text { Born }<32 \\
\text { weeks GA }\end{array}$ & & $\begin{array}{l}\text { ORs not } \\
\text { calculated } \\
\text { although } \\
\text { significance } \\
\text { noted. Gene- } \\
\text { gene } \\
\text { regression } \\
\text { performed. }\end{array}$ & & $<32$ & & & Nelson ${ }^{43}$ \\
\hline & & & & & & & eNOS - 922 & & $<32$ & significance & & Nelson ${ }^{43}$ \\
\hline
\end{tabular}




\begin{tabular}{|c|c|c|c|c|c|c|c|c|c|c|c|c|}
\hline \multirow[b]{2}{*}{$\begin{array}{l}\text { Study area / } \\
\text { population }\end{array}$} & \multirow[b]{2}{*}{ Study type } & \multicolumn{2}{|c|}{ Cases } & \multirow{2}{*}{$\begin{array}{c}\begin{array}{c}\text { Comparison } \\
\text { group }\end{array} \\
\text { Number }\end{array}$} & \multirow[b]{2}{*}{$\begin{array}{l}\text { Inclusion/ } \\
\text { exclusion } \\
\text { criteria }\end{array}$} & \multirow[b]{2}{*}{$\begin{array}{l}\text { Other data } \\
\text { recorded }\end{array}$} & \multirow[b]{2}{*}{ Polymorphism } & \multirow[b]{2}{*}{ Comparison } & \multirow[b]{2}{*}{$\begin{array}{l}\text { Gestational } \\
\text { age (weeks) }\end{array}$} & \multirow[b]{2}{*}{ Degree of risk } & \multirow[b]{2}{*}{$\begin{array}{c}95 \% \mathrm{Cl}, \mathrm{P} \\
\text { value }\end{array}$} & \multirow[b]{2}{*}{ Reference } \\
\hline & & CP type & Number & & & & & & & & & \\
\hline & & & & & & & eNOS - 690 & & $<32$ & & & Nelson ${ }^{43}$ \\
\hline & & & & & & & $\begin{array}{c}\text { eNOS } \\
\text { glu298asp }\end{array}$ & & $<32$ & & & Nelson ${ }^{43}$ \\
\hline & & & & & & & $\begin{array}{c}\text { ADD1 } \\
\text { gly460trp }\end{array}$ & & $<32$ & & & Nelson ${ }^{43}$ \\
\hline & & & & & & & $\begin{array}{l}\text { ADRB2 } \\
\text { arg16gly }\end{array}$ & & $<32$ & & & Nelson ${ }^{43}$ \\
\hline & & & & & & & $\begin{array}{c}\text { ADRB2 } \\
\text { gln27glu }\end{array}$ & & $<32$ & & & Nelson ${ }^{43}$ \\
\hline & & & & & & & $\begin{array}{c}\text { AGT } \\
\text { met235thr }\end{array}$ & & $<32$ & & & Nelson ${ }^{43}$ \\
\hline & & & & & & & AGTR1 1166 & & $<32$ & & & Nelson ${ }^{43}$ \\
\hline & & & & & & & GNB3 825 & & $<32$ & & & Nelson ${ }^{43}$ \\
\hline & & & & & & & ATGA2 873 & & $<32$ & & & Nelson ${ }^{43}$ \\
\hline
\end{tabular}




\begin{tabular}{|c|c|c|c|c|c|c|c|c|c|c|c|c|}
\hline \multirow[b]{2}{*}{$\begin{array}{l}\text { Study area / } \\
\text { population }\end{array}$} & \multirow[b]{2}{*}{ Study type } & \multicolumn{2}{|c|}{ Cases } & \multirow{2}{*}{$\begin{array}{c}\begin{array}{c}\text { Comparison } \\
\text { group }\end{array} \\
\text { Number }\end{array}$} & \multirow[b]{2}{*}{$\begin{array}{l}\text { Inclusion/ } \\
\text { exclusion } \\
\text { criteria }\end{array}$} & \multirow[b]{2}{*}{$\begin{array}{l}\text { Other data } \\
\text { recorded }\end{array}$} & \multirow[b]{2}{*}{ Polymorphism } & \multirow[b]{2}{*}{ Comparison } & \multirow[b]{2}{*}{$\begin{array}{l}\text { Gestational } \\
\text { age (weeks) }\end{array}$} & \multirow[b]{2}{*}{ Degree of risk } & \multirow[b]{2}{*}{$\begin{array}{l}95 \% \mathrm{Cl}, \mathrm{P} \\
\text { value }\end{array}$} & \multirow[b]{2}{*}{ Reference } \\
\hline & & CP type & Number & & & & & & & & & \\
\hline & & & & & & & $\begin{array}{c}\text { ITGB3 } \\
\text { leu33pro }\end{array}$ & & $<32$ & & & Nelson ${ }^{43}$ \\
\hline & & & & & & & MMP3 - 1171 & & $<32$ & & & Nelson ${ }^{43}$ \\
\hline & & & & & & & NPPA 664 & & $<32$ & & & Nelson ${ }^{43}$ \\
\hline & & & & & & & NPPA 2238 & & $<32$ & & & Nelson ${ }^{43}$ \\
\hline & & & & & & & $\begin{array}{l}\text { SCNN1A } \\
\text { trp493ag }\end{array}$ & & $<32$ & & & Nelson ${ }^{43}$ \\
\hline & & & & & & & $\begin{array}{l}\text { SCNN1A } \\
\text { ala663thr }\end{array}$ & & $<32$ & & & Nelson ${ }^{43}$ \\
\hline & & & & & & & $\begin{array}{c}\text { SELE } \\
\text { ser128arg }\end{array}$ & & $<32$ & & & Nelson ${ }^{43}$ \\
\hline & & & & & & & $\begin{array}{c}\text { SELE } \\
\text { leu554phe }\end{array}$ & & $<32$ & & & Nelson ${ }^{43}$ \\
\hline
\end{tabular}




\begin{tabular}{|c|c|c|c|c|c|c|c|c|c|c|c|c|}
\hline & & \multicolumn{2}{|c|}{ Cases } & \multirow{2}{*}{$\begin{array}{c}\begin{array}{c}\text { Comparison } \\
\text { group }\end{array} \\
\text { Number }\end{array}$} & \multirow[b]{2}{*}{$\begin{array}{l}\text { Inclusion/ } \\
\text { exclusion } \\
\text { criteria }\end{array}$} & \multirow[b]{2}{*}{$\begin{array}{l}\text { Other data } \\
\text { recorded }\end{array}$} & \multirow[b]{2}{*}{ Polymorphism } & \multirow[b]{2}{*}{ Comparison } & \multirow[b]{2}{*}{$\begin{array}{l}\text { Gestational } \\
\text { age (weeks) }\end{array}$} & \multirow[b]{2}{*}{ Degree of risk } & \multirow[b]{2}{*}{$\begin{array}{c}95 \% \mathrm{Cl}, \mathrm{P} \\
\text { value }\end{array}$} & \multirow[b]{2}{*}{ Reference } \\
\hline $\begin{array}{l}\text { Study area/ } \\
\text { population }\end{array}$ & Study type & CP type & Number & & & & & & & & & \\
\hline UK, Caucasian. & $\begin{array}{l}\text { Longitudinal } \\
\text { study, case } \\
\text { study }\end{array}$ & Not recorded & $17 / 207$ & - & $\begin{array}{l}\text { Born } \leq 32 \mathrm{GA}, \\
\text { participated } \\
\text { in an early } \\
\text { education } \\
\text { program } \\
\text { focussed on } \\
\text { the child or } \\
\text { social } \\
\text { support. }\end{array}$ & 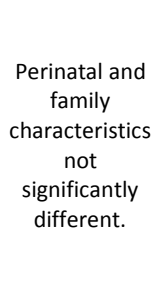 & $\begin{array}{l}\text { Cox2 (- } \\
7656 / C)\end{array}$ & $\mathrm{GG}$ vs $\mathrm{CG} / \mathrm{CC}$ & $\leq 32$ & $\begin{array}{c}13 / 139(9 \%) \text { vs } \\
4 / 68(6 \%)\end{array}$ & $\mathrm{P}=0.59$ & Harding ${ }^{82}$ \\
\hline $\begin{array}{l}\text { Australia, } \\
\text { Caucasian }\end{array}$ & $\begin{array}{l}\text { Case- } \\
\text { control }\end{array}$ & $\begin{array}{l}\text { Diplegia, } \\
\text { hemiplegia, } \\
\text { quadriplegia }\end{array}$ & 443 & 883 & & $\begin{array}{l}\text { Results } \\
\text { reflected in } \\
\text { those testing } \\
\text { positive to } \\
\text { viral exposure } \\
\text { but not } \\
\text { present in } \\
\text { those without } \\
\text { viral } \\
\text { exposure. }\end{array}$ & $\begin{array}{c}\text { MBL } \\
\text { Haplotypes }\end{array}$ & & & & & Gibson $^{6}$ \\
\hline & & & & & & & LYPA & All types, & All GAs & OR 1.57 & $1.00-2.46$ & Gibson $^{6}$ \\
\hline & & & & & & & & & $<37$ & OR 2.43 & $1.41-4.18$ & Gibson ${ }^{6}$ \\
\hline & & & & & & & & & $<32$ & OR 2.54 & $1.34-4.76$ & Gibson $^{6}$ \\
\hline & & & & & & & & Hemiplegia & $<37$ & OR 2.77 & $1.02-7.26$ & Gibson $^{6}$ \\
\hline & & & & & & & & Hemiplegia & $<32$ & OR 4.48 & $1.55-12.65$ & Gibson $^{6}$ \\
\hline & & & & & & & HYPD & Quadriplegia & All GAs & OR 3.47 & $1.41-8.31$ & Gibson $^{6}$ \\
\hline & & & & & & & & Quadriplegia & $<32$ & OR 7.86 & $1.67-29.48$ & Gibson $^{6}$ \\
\hline $\begin{array}{l}\text { Australia } \\
\text { Caucasian }\end{array}$ & $\begin{array}{l}\text { Case- } \\
\text { Control }\end{array}$ & $\begin{array}{l}\text { Diplegia, } \\
\text { hemiplegia, } \\
\text { quadriplegia }\end{array}$ & 443 & 883 & & & ALOX5AP-2 & $\begin{array}{l}\text { Girls, all CP types, } \\
\text { homozygous vs normal }\end{array}$ & All GAs & OR 2.03 & $\begin{array}{c}\text { 1.13-3.64, } \\
p=0.02\end{array}$ & Gibson ${ }^{22}$ \\
\hline
\end{tabular}




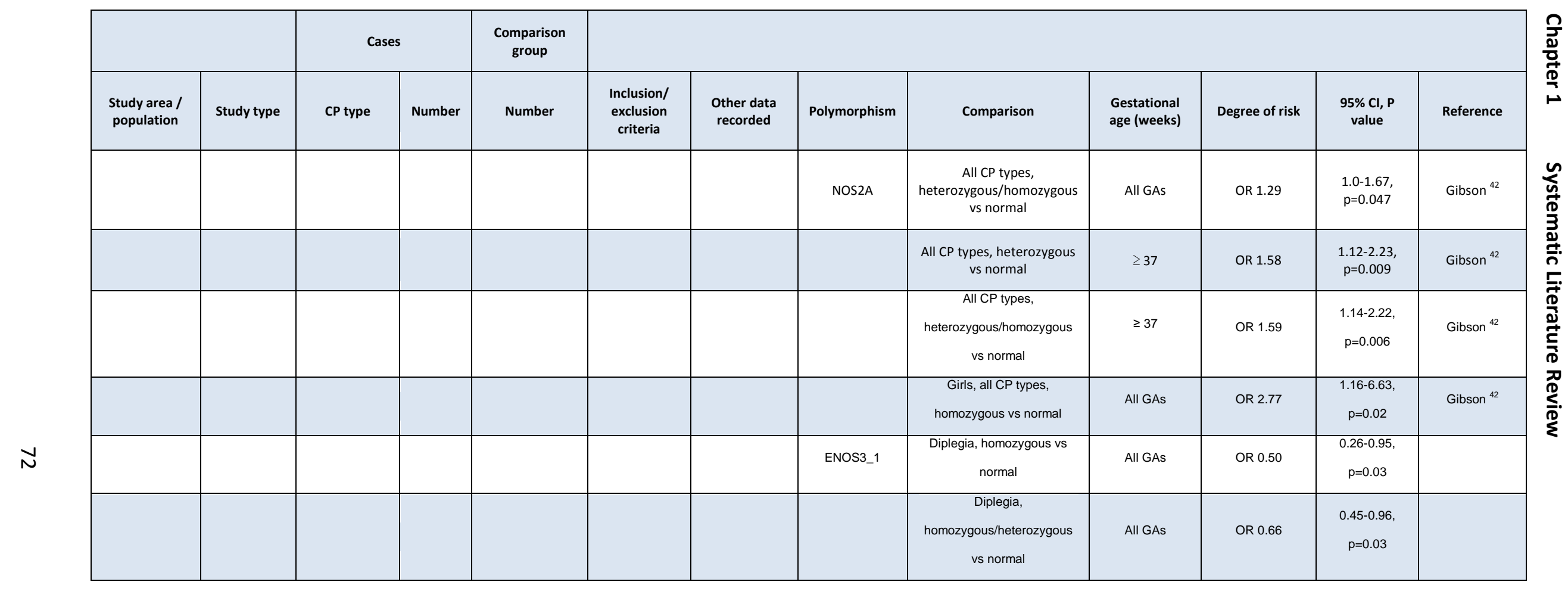


Chapter 2 Study Protocol and Hypotheses

\section{Conclusions and future directions}

SNP associations with cerebral palsy has been reported by a number of investigators; however conclusions remain controversial largely due to small sample sizes and the inability to compare results between cerebral palsy sub-types and ethnic groups. Further ambiguity exists where insufficient epidemiological data has been collected. The better studies suggest possible associations of FVL, MTHFR C776T, TNF- $\alpha-308$ LTA, eNOS and MBL with cerebral palsy outcome. Many studies were subject to error from multiple analysis of subgroups (type I error) and analyses of small numbers in some sub-groups (type II error); however the data to date has nominated several candidate genes for further study.

A number of recommendations for further SNP association studies with cerebral palsy can be made. The field would benefit from further case-control studies with $>200$ participants to confirm the results of exploratory and smaller studies - this thesis describes such a study. It is unlikely that one study can test all hypotheses considering the ethnic distribution of many SNPs and the need to recruit a homogenous population to generate sufficient statistical power. Studies are beginning to examine both multiple gene ${ }^{6,43}$ and gene-environment ${ }^{6}$ interactions and this may produce further significant associations in the future. In total, only 52 SNPs have been investigated for association with cerebral palsy and studies are largely hypothesis driven. It is now possible to test $>1$ million SNPs simultaneously using SNP chip arrays and this avenue may suggest further SNPs for investigation, though type I errors are likely to be present. New SNPs may influence physiological pathways other than coagulation or inflammation and generate further hypotheses of cerebral palsy causation.

Very few studies have examined the contribution of maternal genotype ${ }^{44}$ to cerebral palsy outcome in the infant and given the importance of events such as thromboses and infection within the mother, further study is needed. The origin of the SNPs investigated is also largely uninvestigated. Are SNPs inherited from a child's mother or father or do they arise de novo? This 


\section{Chapter 2 Study Protocol and Hypotheses}

has important implications if one considers applying SNP testing diagnostically to assess possible cerebral palsy outcome in a couple's children.

Combining gene-gene interaction studies and gene-environment interaction studies may produce enough significance to recommend therapeutic interventions to reduce the risk of a cerebral palsy outcome for a pregnancy. A substantial amount of further evidence is required before clinical practice will be changed. 


\section{Chapter 2 Study Protocol and Hypotheses}

\section{Additional literature}

The systematic literature review presented in this chapter was published in February $2009^{85}$. Following publication of the manuscript, but prior to submission of this thesis, four additional publications were identified that match the inclusion criteria for the HuGE systematic review, but with publication dates between November 2008 and January 2011 . The physiology of the SNPs described in these four additional publications is described above, together with a possible mechanism for their association with cerebral palsy. A summary of each paper is provided below.

Djukic et al. ${ }^{86}$ investigate candidate SNPs TLR-4 Asp299Gly, IL-6 G-174C and IL-4 C-589T in the same cohort described by Gibson et al. ${ }^{5,6,14}$. Four-hundred and forty three cerebral palsy cases and 883 controls of Caucasian background were genotyped using DNA extracted from Guthrie cards. Correlations were also made with detection of viral nucleic acids in the same Guthrie cards. Hardy Weinberg equilibrium was demonstrated for genotyping of all SNPs in the control group and genotyping rates $>95 \%$ were reported for TLR-4 and IL-6 but not IL-4 (92\%).

TLR-4 was associated with a decreased risk of cerebral palsy at all gestational ages (homozygous/heterozygous odds ratio $0.70,95 \%$ confidence interval $0.50-0.98$ ).

IL-6 was associated with an increased risk of hemiplegia at all gestational ages (odds ratio $1.38,95 \%$ confidence interval $1.05-1.83$ ) and was associated with quadriplegia when considering those born from 32-36 weeks gestational age (homozygous/heterozygous odds ratio 10.42, 95\% confidence interval 1.34-80.82).

IL-4 was associated with a decreased risk of cerebral palsy in infants born at less than 32 weeks gestational age with no detectable viral nucleic acid in their Guthrie card (homozygous/heterozygous odds ratio $0.31,95 \%$ confidence interval $0.13-0.76$ ); but was associated with an increased risk of quadriplegia in infants born at less than 37 weeks gestational 


\section{Chapter 2 Study Protocol and Hypotheses}

age with evidence of viral nucleic acid in their Guthrie card (homozygous/heterozygous odds ratio $4.25,95 \%$ confidence interval $1.21-14.95)$.

This study has the same weakness as previous publications describing the same cohort ${ }^{5}$, ${ }^{6,14}$ and these are discussed above. Multiple tests of small subgroups were conducted with no statistical correction made to the analyses.

Wu et al. ${ }^{87}$ examine 250 cases of cerebral palsy and 305 controls of mixed ethnicity born at $\geq 36$ weeks gestational age. DNA was extracted from Guthrie cards and the SNP IL-6-174 G/C was genotyped. Genotyping success rates are reported ( $93.6 \%$ in cases and $95.4 \%$ in controls) and genotype allele frequencies were in Hardy Weinberg equilibrium for the control cohort. The CC genotype was significantly associated with cerebral palsy when compared to the GG genotype (odds ratio 2.6, 95\% confidence interval 1.5-4.6) when adjusting for race. The CC genotype remained significantly associated with cerebral palsy in dominant, recessive and additive models (dominant: $[\mathrm{GC}+\mathrm{CC}]$ vs $\mathrm{GG}$, odds ratio $1.6,95 \%$ confidence interval 1.1-2.3, $\mathrm{p}=0.02$; recessive: [CC vs [GC + GG], odds ratio 2.3, 95\% confidence interval 2.3 1.3-4.0, $\mathrm{p}=0.003$; additive: 0,1 or 2 alleles, odds ratio $1.5,95 \%$ confidence interval $1.2-2.0, p=0.001)$. The $\mathrm{CC}$ genotype also remained significantly associated with cerebral palsy in a multivariable logistic regression model including other risk factors for cerebral palsy such as clinical chorioamnionitis, maternal age $\geq 35$ years, male gender, birth weight $<2,000 \mathrm{~g}$ and maternal race (odds ratio $2.4,95 \%$ confidence interval 1.3-4.4, $p=0.004)$. Assessment of cerebral palsy subtype showed CC genotype association with quadriplegia (odds ratio 4.1, 95\% confidence interval 1.8-9.3) and hemiplegia (odds ratio $2.7,95 \%$ confidence interval 1.3-5.7) after adjusting for race. This study minimised error due to multiple testing by examining only one SNP; however assessment of different racial groups, cerebral palsy subtypes, cerebral palsy severity level and multiple genotype models were still conducted without correction. The effective use of multivariable analysis allowed correction for differences in allele frequencies between racial groups and also adjustment for clinically important risk 


\section{Chapter 2 Study Protocol and Hypotheses}

factors for cerebral palsy such as chorioamnionitis. Examination of IL-6 by Djukic et al. ${ }^{86}$ did not support associations in the same gestational age subgroups and these results require replication.

Braga et al. ${ }^{88}$ examine APOE genotype in 243 cerebral palsy cases and 243 controls matched for age, sex and race. DNA was obtained from buccal swabs but no details of genotyping success rate or Hardy Weinberg equilibrium testing are reported. The authors describe an association of e2e3 genotype with cerebral palsy (odds ratio $2.8,95 \%$ confidence interval 1.01-7.66, $27 / 243$ vs $12 / 243$ examples) and also an association of e2 allele presence with cerebral palsy (odds ratio $3.2,95 \%$ confidence interval $1.27-7.66,35 / 243$ vs $14 / 243$ examples). The authors also examined APOE associations with cerebral palsy subtype and severity level of motor involvement without significant findings. The results of this study are difficult to interpret given the ethnic diversity of the cohort; although a study by Kuroda et al. ${ }^{54}$ also reports an association of e2 with cerebral palsy in a Brazilian population. The association of e4 with cerebral palsy reported by Meirelles et al. ${ }^{53}$ was not confirmed in this study. A study of APOE genotype and cerebral palsy reported by McMichael et al. ${ }^{55}$ does support a trend towards association of e2 with cerebral palsy albeit in small numbers. A larger cohort is required to confirm this association.

Cheng et al. ${ }^{89}$ describe a Chinese cohort of 159 cerebral palsy cases (43 were also diagnosed with mental retardation) and 169 controls matched for age, sex and ethnicity. This proportion of intellectual disability within the cerebral palsy cohort is to be expected and consistent with a population prevalence of $39 \%$ in Australia ${ }^{94}$. Five MTHFR SNPs were examined and were not associated with cerebral palsy when compared to controls. When examining the same SNPs in only cerebral palsy cases with mental retardation and comparing to controls, SNPs rs4846049 $(p=0.009), \quad r s 1476413(p=0.008)$ and $r s 1801131 \quad(p=0.004)$ were significantly associated. SNP haplotypes were also examined with no significant association between haplotypes and cerebral palsy when comparing all cases and controls, but the TTGGT haplotype 


\section{Chapter 2 Study Protocol and Hypotheses}

was associated with a combination of cerebral palsy and mental retardation (haplotype block: rs4846049, rs1476413, rs1801131, rs1801133, rs9651118, p=0.005 after Bonferroni correction for 5 haplotype tests, odds ratio 2.7 95\% confidence interval 1.47-4.94). No significant associations were found when considering gender, gestational age, birth weight and birth asphyxia. Previous studies of MTHFR SNPs and cerebral palsy have been conducted in Caucasians and have not considered mental retardation in their analysis ${ }^{14}$ making the study by Cheng et al. difficult to compare with the literature. The results of Cheng et al. require replication in a comparable population. The study also raises the possibility of examining cerebral palsy cases with mental retardation in other ethnic groups and further examining MTHFR haplotypes.

Although appearing in the literature after the systematic review presented in chapter 1 was published, these papers do not substantially change the conclusions. These four studies describe small cohorts of cerebral palsy cases, conduct multiple tests and subgroup analyses and require replication in larger cohorts. The majority of SNPs described in these additional papers are in the candidate SNP panel of this study. 
Chapter 2 Study Protocol and Hypotheses

Chapter 2 Study Protocol and Hypotheses 


\section{Chapter 2 Study Protocol and Hypotheses}

The Australian Cerebral Palsy Research Study - Protocol for a National Collaborative Study Investigating Genomic and Clinical Associations with Cerebral Palsy*

O'Callaghan $\mathrm{ME}^{1}$, MacLennan $\mathrm{AH}^{1}$, Gibson $\mathrm{CS}^{1}$, McMichael $\mathrm{GL}^{1}$, Haan EA2, Broadbent $\mathrm{J}^{1}$, Priest $\mathrm{K}^{3}$, Goldwater $\mathrm{PN}^{3}$, Dekker GA ${ }^{1}$.

Journal of Paediatrics and Child Health. 2010 Nov 21.

doi: 10.1111/j.14401754.2010.01896.x. Published online ahead of print.

${ }^{1}$ Discipline of Obstetrics and Gynaecology, School of Paediatrics and Reproductive Health, The Robinson Institute, University of Adelaide, South Australia.

${ }^{2}$ SA Clinical Genetics Service, SA Pathology at Women's and Children's Hospital and Discipline of Paediatrics, The University of Adelaide, South Australia.

${ }^{3}$ Epidemiology Branch, SA Health, South Australia

${ }^{4}$ Departments of Microbiology and Infectious Diseases, SA Pathology at Women's and Children's Hospital, South Australia.

\footnotetext{
* Published paper appears in this thesis as Chapter 2
} 
Chapter 2 Study Protocol and Hypotheses

\section{Statement of authorship}

The Australian Cerebral Palsy Research Study - Protocol for a National Collaborative Study Investigating Genomic and Clinical Associations with Cerebral Palsy

Journal of Paediatrics and Child Health. 2010 Nov 21. doi: 10.1111/j.1440-1754.2010.01896.x. Published online ahead of print.

\section{O'Callaghan ME (Candidate)}

Participated in all aspects of this publication including the design, laboratory work, ethics submissions, recruitment, data linkage, statistical analysis, interpretation of this study and preparation of the manuscript.

I hereby certify that the statement of contribution is accurate

\section{MacLennan AH}

Principal supervisor, contributed to the study design, data interpretation and manuscript.

I hereby certify that the statement of contribution is accurate 


\section{Chapter 2 Study Protocol and Hypotheses}

\section{Gibson CS}

Contributed to the study design, data interpretation and manuscript.

I hereby certify that the statement of contribution is accurate

\section{McMichael GL}

Contributed to the laboratory work and manuscript.

I hereby certify that the statement of contribution is accurate

\section{Haan EA}

Co-supervisor, contributed to the study design, data interpretation and manuscript.

I hereby certify that the statement of contribution is accurate 
Chapter 2 Study Protocol and Hypotheses

\section{Broadbent J}

Contributed to the ethics submissions, participant recruitment and manuscript.

I hereby certify that the statement of contribution is accurate

\section{Priest K}

Contributed to the data linkage and manuscript.

I hereby certify that the statement of contribution is accurate

\section{Goldwater PN}

Contributed to the study design, data interpretation and manuscript.

I hereby certify that the statement of contribution is accurate 


\section{Chapter 2 Study Protocol and Hypotheses}

\section{Dekker GA}

Co-supervisor, contributed to the study design, data interpretation and manuscript.

I hereby certify that the statement of contribution is accurate 


\section{Chapter 2 Study Protocol and Hypotheses}

\section{Abstract}

\section{Introduction}

Previous studies have proposed a link between the presence of specific SNPs and cerebral palsy and the majority of these associations remain to be confirmed or rejected by prospective studies with sufficient statistical power. Prior studies have also given little attention to the interaction of genomic characteristics and clinical risk factors.

\section{Methods}

This chapter describes the design of a prospective case-control study to test these genetic associations in conjunction with more stringent data collection in respect to clinical features associated with pregnancy, particularly maternal infection. Here we consider our hypothesis that genetic susceptibility modifies the risk of cerebral palsy in the presence of perinatal environmental triggers, a priori primary and secondary aims, power calculations, the ethical requirements, participant recruitment strategies, data linkage, sampling methods of genetic material and subsequent SNP analysis, collection of clinical data and the proposed final statistical analysis. 


\section{Chapter 2 Study Protocol and Hypotheses}

\section{Introduction}

A recent systematic review ${ }^{85}$ identified 22 publications investigating a link between the carriage of specific Single Nucleotide Polymorphisms (SNPs) and cerebral palsy outcome. Functional SNPs studied to date have included SNPs associated with thrombophilia ${ }^{14}$, SNPs affecting cytokine gene function ${ }^{5}$, SNPs in the APOE gene ${ }^{90}$ and other SNPs ${ }^{43}$, largely related to cardiac function. Studies conducted to date have typically been in small cohorts, sometimes poorly controlled and lacking statistical power. The majority of these associations remain to be reinvestigated in an independent cohort, ideally of much larger size allowing adequate power to test hypotheses.

The interaction of known clinical risk factors for cerebral palsy has been largely neglected. Factors including a sibling with cerebral palsy ${ }^{11}$, preterm birth, size for gestational age ${ }^{91}$ and maternal infections during pregnancy ${ }^{8}$ have all been associated with cerebral palsy. These factors not only contribute to cerebral palsy outcome but their interaction with an individual's genotype may also be important. Cytokine gene polymorphisms have been identified as a moderate risk factor for cerebral palsy ${ }^{5}$ with a doubling of the odds ratio for cerebral palsy outcome. In the presence of viral DNA detected in neonatal blood spots the IL-4 polymorphism C589T has been associated with a 4 fold increase in the risk of cerebral palsy compared to children with this mutation who did not have evidence of perinatal viral infection ${ }^{86}$. Cerebral palsy risk is also greater in babies with evidence of both viral DNA detected in neonatal blood spots and the $A P O E \varepsilon 2$ allele ${ }^{90}$. These results would be consistent with the hypothesis that a functional cytokine polymorphism could contribute to cerebral palsy outcome by altering the fetal inflammatory response to infection or other inflammatory stimuli occurring in utero i.e. the combination of genomic and clinical risk factors is more likely to result in cerebral palsy outcome. Similar interactions between genotypic and clinical risk factors are also likely to occur between other immune function-related SNPs and infection and also between thrombophilic genotypes 
Chapter 2 Study Protocol and Hypotheses

and infection. This hypothesis has yet to be tested in a large cohort and collection of information about clinical risk factors requires a prospective study design. 


\section{Chapter 2 Study Protocol and Hypotheses}

\section{Hypothesis under test}

It is hypothesised that specific genetic variations alter susceptibility to cerebral palsy and interact with clinical/environmental triggers to further alter the risk of cerebral palsy. This protocol has been designed to examine the contribution of, and interaction between, fetal and maternal cytokine or thrombophilic polymorphisms and clinical risk factors which may promote double jeopardy for development of cerebral palsy.

\section{Primary aims}

1) To test a preselected group of candidate maternal and fetal SNPs for association with cerebral palsy outcome.

2) To document the prevalence of known clinical risk factors for cerebral palsy in an independent cohort.

3) To assess the interaction of genetic and clinical risk factors for cerebral palsy by multivariable analysis.

\section{Secondary aims}

1) To test SNP associations with cerebral palsy subtypes in an independent cohort.

2) To test SNP associations with cerebral palsy by gestational age in an independent cohort.

3) To test combinations of maternal and fetal SNP carriage for association with cerebral palsy outcome. 
Chapter 2 Study Protocol and Hypotheses

\section{Methods}

\section{Study design}

A prospective case-control study has been designed to test the proposed double jeopardy hypothesis and confirm or reject previous genetic associations reported in the literature.

\section{Sample size calculation}

Sample size was calculated to detect significant associations with $80 \%$ power and an $\alpha$ value of 0.01 using a chi-squared statistic uncorrected for multiple testing. The odds ratio detectable in a study depend on the number of cases and controls and on the prevalence of the polymorphisms being studied. A breakdown of detectable differences over a range of cohort sizes, with specific SNP prevalences, is shown in Table 1. The SNP prevalence's have been taken from published results in a South Australian population. Recruitment for the study commenced on $3^{\text {rd }}$ July 2008 and closed on March $31^{\text {st }} 2010$ and achieved 840 cases and 1,320 controls, well within this range. Calculations assumed an additive genetic model and were performed using PS: Power and Sample Size Calculation version 3.0, 2009. Effect sizes in the literature may be biased (publication bias) and consequent sample sizes calculated to achieve sufficient power could therefore be underestimated. 


\section{Chapter 2 Study Protocol and Hypotheses}

Table 1

Detectable odds ratios for selected SNPs under test with $80 \%$ power, $\alpha 0.01$ using an uncorrected chi-squared statistic to evaluate the null hypothesis.

\begin{tabular}{|c|c|c|c|c|c|}
\hline SNP & $\begin{array}{l}\text { Reported } \\
\text { population } \\
\text { prevalence }\end{array}$ & Reference & $\begin{array}{l}\text { Detectable odds ratio for } \\
500 \text { cases and } 500 \\
\text { controls }\end{array}$ & $\begin{array}{c}\text { Detectable odds ratio for } \\
500 \text { cases and } 1000 \\
\text { controls }\end{array}$ & $\begin{array}{c}\text { Detectable odds ratio for } \\
1,000 \text { cases and } 1,000 \\
\text { controls }\end{array}$ \\
\hline $\begin{array}{l}\text { Thrombophilia: MTHFR } \\
\text { C677T Homozygous }\end{array}$ & $12.4 \%$ & 92 & 0.462 or 1.810 & 0.514 or 1.669 & 0.599 or 1.536 \\
\hline $\begin{array}{l}\text { Thrombophilia: MTHFR } \\
\text { C677T Heterozygous }\end{array}$ & $37.3 \%$ & 92 & 0.628 or 1.550 & 0.669 or 1.461 & 0.724 or 1.365 \\
\hline $\begin{array}{l}\text { Thrombophilia: } \quad \mathrm{FVL} \\
\text { Homozygous }\end{array}$ & $0.7 \%$ & 92 & 5.840 & 4.547 & 3.883 \\
\hline $\begin{array}{l}\text { Thrombophilia: } \quad \text { FVL } \\
\text { Heterozygous }\end{array}$ & $9.5 \%$ & 92 & 0.404 or 1.923 & 0.459 or 1.758 & 0.552 or 1.610 \\
\hline $\begin{array}{l}\text { Cytokines: } \\
\text { TNF- } \alpha-308 \text { Homozygous }\end{array}$ & $4.3 \%$ & 5 & 0.196 or 2.426 & 0.254 or 2.145 & 0.384 or 1.926 \\
\hline $\begin{array}{l}\text { Cytokines: } \\
\text { TNF- } \alpha-308 \text { Heterozygous }\end{array}$ & $26.8 \%$ & 5 & 0.592 or 1.594 & 0.635 or 1.496 & 0.696 or 1.396 \\
\hline
\end{tabular}


Chapter 2 Study Protocol and Hypotheses

\section{Cases}

Cerebral palsy cases were prospectively recruited from all states of Australia and the ACT. Children were required to have a specialist diagnosis of cerebral palsy (where possible confirmed by a State cerebral palsy register), be aged 5-18 years within the recruitment period (July 2008 March 2010), of Caucasian origin and have been born in Australia. Mothers of participating children received a study information sheet and gave written informed consent to participate with their child. Recruitment advertising included a study website (www.adelaide.edu.au/cerebralpalsy), media and community advertising, posters placed in appropriate specialist clinics around Australia, direct invitation by cerebral palsy registers (South Australia, Victoria, Queensland and New South Wales/ACT) and advertisement in special schools and by cerebral palsy support groups around Australia.

Target numbers of cases to be recruited from each Australian state and territory were calculated based upon the number of cases reported in the registers of each state and territory (Table 2). 


\section{Chapter 2 Study Protocol and Hypotheses}

\section{Table 2}

Number of cases that could be recruited from each Australian state/Territory. We have conservatively estimated a 55\% participation rate from contactable families. Power calculations are based on up to 1,000 cases and 1,000 controls.

\begin{tabular}{|l|l|}
\hline \multicolumn{1}{|c|}{ State/Territory } & \multicolumn{1}{c|}{ Cerebral palsy cases } \\
\hline NSW/ACT & 509 \\
\hline QLD & 357 \\
\hline TAS & 138 \\
\hline VIC & 660 \\
\hline SA & 286 \\
\hline WA & 550 \\
\hline Total & 2,500 \\
\hline
\end{tabular}

\section{Controls}

Controls were also recruited in all States and Territories of Australia and were required to be of Caucasian background, aged between 5 and 18 years and not have cerebral palsy (not on a cerebral palsy register). Recruitment of controls occurred over the same time period as cases. Mothers of these children also gave their informed consent to participate with their child. The cohort was approached through media advertising around Australia and through school invitation letters throughout Australia. Schools were classified as metropolitan private or government, rural private or government and broken into primary, secondary, senior secondary (years 10-12) or area divisions. The relative number of students recruited in each group sought to provide a control cohort representative of the school children in each state/territory. Principals were initially approached seeking the support of their school. Advertisement included a letter inviting families to participate in the study, posters displayed in schools, advertisements in school newsletters and assembly visits. Control recruitment also occurred through media advertising, 


\section{Chapter 2 Study Protocol and Hypotheses}

families visiting paediatric fracture clinics and public display booths. Targets set for each state/territory reflected the number of cases targeted in each state/territory.

Significant differences in genotype distribution have been reported between ethnic groups for some of the genotypes under investigation ${ }^{41}$. It was therefore important to examine a homogenous group for possible associations. In Australia this was only practical for Caucasians, who form the majority of the population. For the purpose of this study, Caucasian was defined as 'of European ancestry' and was self reported by participants before cross checking against the midwife notes. Participants were required to be Australian born to enable data linkage to birth records. Children aged between 5 and 18 years were selected for this study for two reasons. Firstly, children aged up to 5 years of age may still be diagnosed with cerebral palsy and it was important that control children did not have cerebral palsy. Secondly, children aged up to 18 years of age are more likely to be living with their parents, facilitating recruitment of mother/child pairs.

\section{Ethics approval}

The national dimension of this study required ethics approval from multiple ethics committees in all states of Australia and the ACT. A NEAF (National Ethics Application Form) was prepared and utilised but many ethics committees required their own forms and approval mechanisms. A total of 23 ethics committees and statutory bodies gave permission for this study.

\section{South Australia}

Children's Youth and Women's Health Service Human Research Ethics Committee, Department of Education Ethics Committee, SA Health Ethics Committee and Novita Children's Services Research Committee.

\section{Victoria}

Department of Education (four jurisdictions), The Consultative Council on Obstetric and Paediatric Mortality and Morbidity and the SCOPE Ethics Committee. 


\section{Chapter 2 Study Protocol and Hypotheses}

\section{Western Australia}

Department of Education and Training and Department of Health.

New South Wales

Department of Education, the Spastic Centre Research Ethics Committee and the Cancer Institute of NSW.

\section{Australian Capital Territory}

ACT Health, Department of Education and Training and the Catholic Education Office.

\section{Queensland}

Queensland Health and the Cerebral Palsy League of Queensland Research Ethics Committee.

\section{Tasmania}

The Health Research Ethics Committee (Tasmania) and the Department of Education.

\section{Data integrity}

All data was de-identified and stored in a secure customised database (Jelka Software, SA) with $10 \%$ entered and checked twice for internal validity. Hard copies of questionnaires and consent forms were stored securely in locked cabinets identified by personalised barcodes. Genotyping was performed by staff blinded to case or control status and data analysis was performed without knowledge of the personal details of participants.

Participants who sent incomplete questionnaires were recontacted by mail for missing information and a new swab was requested when the initial one did not provide DNA of sufficient quantity and quality for successful multiplex PCR testing. Participants enrolling but not returning swabs were also recontacted by phone and/or by mail at least once. 


\section{Chapter 2 Study Protocol and Hypotheses}

\section{Genetic data}

\section{DNA collection}

Optimisation of DNA collection and extraction methods are described in detail elsewhere

${ }^{90}$. In brief, DNA was self collected by participants using a buccal swab (Catch-all, Epicentre, Madison, WI, USA). Swabs were clearly labelled for mother or child use, and bar-coded for laboratory identification. They were mailed to enrolled participants with a detailed instruction sheet (a supplementary video was also available at www.adelaide.edu.au/cerebralpalsy) which included particulars for return using the accompanying reply paid envelope.

\section{DNA extraction}

DNA was extracted from the swabs using a Buccal DNA Isolation Kit (Isohelix, Kent, UK) with minor modifications to the manufacturer's protocol. In brief, swabs were placed in cell lysis buffer and proteinase inhibitors were added. Swabs were heated in buffer at $60^{\circ} \mathrm{C}$ for one hour and then DNA was precipitated. Precipitated DNA was pelleted by 15 minute centrifuge at 14,000rpm and the supernatant discarded. The pellets were dried for 1 hour at room temperature to ensure that all the buffer solution had been removed. DNA was then resuspended in $75 \mathrm{UL} \mathrm{TE}$ buffer for $-20^{\circ} \mathrm{C}$ storage and subsequent multiplex PCR. DNA of sufficient quantity and quality for successful multiplex PCR testing was achieved in $93 \%$ of samples returned ${ }^{90}$.

\section{Multiplex PCR}

Multiplex PCR was performed by the Australian Genome Research Facility (Brisbane Node) for 39 SNPs using the Sequenom platform and homogenous MassExtend (hME - single base extension) to differentiate genotypes. Case and control samples were genotyped as they arrived and as a result were effectively randomised.

\section{Candidate genes}




\section{Chapter 2 Study Protocol and Hypotheses}

Candidate genes were chosen from those with significant results in past retrospective studies and from others with possible significance in the published literature (Table 3). Three groups of candidate genes were chosen. SNPs 1-23 are associated with a possible altered inflammatory response. SNPs 24-32 are associated with thrombophilia and SNPs 33-39 are polymorphisms described by us and other past studies as associated with cerebral palsy or preterm delivery. 
Chapter 2 Study Protocol and Hypotheses

Table 3

Candidate SNPs investigated in this study.

\begin{tabular}{|c|c|c|c|c|c|c|c|c|}
\hline \multicolumn{3}{|c|}{$\begin{array}{l}\text { SNPs associated with an altered fetal } \\
\text { inflammatory response }\end{array}$} & \multicolumn{3}{|c|}{ SNPs associated with thrombophilia } & \multicolumn{3}{|c|}{ Other SNPs, most associated with preterm birth } \\
\hline Number & SNP & RS Number & Number & SNP & RS Number & Number & SNP & RS Number \\
\hline 1 & TNF- $\alpha 308$ & 1800629 & 24 & PAI-2_1 & 6098 & 33 & APO-E_1 & 429358 \\
\hline 2 & TNF- $\alpha+488$ & 1800610 & 25 & PAI-2_2 & 6103 & 34 & APO-E_2 & 7412 \\
\hline 3 & TNF- $\alpha-238$ & 361525 & 26 & THBD & 1800576 & 35 & iNOS (NOS2A) & 1137933 \\
\hline 4 & TLR4 299 & 4986790 & 27 & $\mathrm{FVL}$ & 6025 & 36 & eNOS-922 & 1800779 \\
\hline 5 & $\begin{array}{l}\text { MBL codon } \\
52\end{array}$ & 5030737 & 28 & MTHFR 677 & 1801133 & 37 & ADD1 & 4961 \\
\hline 6 & $\begin{array}{l}\text { MBL codon } \\
54\end{array}$ & 1800450 & 29 & $\begin{array}{l}\text { MTHFR } \\
1298\end{array}$ & 1801131 & 38 & ADRB2 Q27E & 1042714 \\
\hline 7 & $\begin{array}{l}\text { MBL codon } \\
57\end{array}$ & 1800451 & 30 & PGM & 1799963 & 39 & Y-specific & Amelogenin ${ }^{1}$ \\
\hline 8 & MBL-221 & 7096206 & 31 & NPY C4112T & 16135 & & & \\
\hline 9 & $\mathrm{MBL}+4$ & 7095891 & 32 & $\begin{array}{l}\text { NPY } \\
\text { A6411C }\end{array}$ & 16476 & & & \\
\hline 10 & MBL-550 & 11003125 & & & & & & \\
\hline 11 & IL-4-589 & 2243250 & & & & & & \\
\hline 12 & IL-8 & 4073 & & & & & & \\
\hline 13 & IL $1 \mathrm{~B}+511$ & 16944 & & & & & & \\
\hline 14 & IL-10-819 & 1800871 & & & & & & \\
\hline 15 & IL-6-174 & 1800795 & & & & & & \\
\hline 16 & CR2-1 & 3813946 & & & & & & \\
\hline 17 & CR2-2 & 1048971 & & & & & & \\
\hline 18 & CR2-3 & 1715 & & & & & & \\
\hline 19 & TGF-B1-29 & 1982073 & & & & & & \\
\hline 20 & TGF-ß1-509 & 1800469 & & & & & & \\
\hline 21 & CFH Y402H & 1061170 & & & & & & \\
\hline 22 & MMP-3 & 602128 & & & & & & \\
\hline 23 & MMP-2 & 243865 & & & & & & \\
\hline
\end{tabular}

${ }^{1}$ Internal genotyping control 


\section{Chapter 2 Study Protocol and Hypotheses}

\section{Epidemiological data}

\section{Questionnaire}

Mothers completed a short questionnaire about their health during the pregnancy of their participating child (Figure 1). This was returned with the swabs by post. Data collected included sufficient detail to enable POSU data linkage and also included details about recalled infections during pregnancy and medications taken. Maternal recall bias is likely to be different between cases and controls for measures collected using this questionnaire. It is likely that mothers of cases to recall their pregnancy in greater detail, possibly biasing results collected from this source of data only. Data from the questionnaire was only used in the study analysis where it could not be supplied by the more accurate Perinatal databases. 
Chapter 2 Study Protocol and Hypotheses 


\section{Figure 1}

Maternal health background questionnaire

Confidential

Barcode

DO GENETIC MUTATIONS PREDISPOSE TO CEREBRAL PALSY? MOTHER AND CHILD HEALTH BACKGROUND QUESTIONNAIRE

1. Has your child been diagnosed with cerebral palsy?

$\square$ Yes $\square$ No If Yes go to question 2, if No go to question 3.

2. Has your child's cerebral palsy been confirmed by a specialist?

$\square$ Yes $\square$ No

What is the name and address of your child's specialist who confirmed this diagnosis, if we need to check the diagnosis?

What is the name and address of your general practitioner if we need to seek missing medical details overleaf?

3. Do you have cerebral palsy?

$\square$ Yes $\square$ No

4. Does your child's father have cerebral palsy?

$\square$ Yes $\square$ No

5. Does any other member of your family or your child's father's family have cerebral palsy?

$\square$ Yes $\square$ No

If Yes, please specify their relationship to your child

e.g. (your child's) grandmother, grandfather, aunt, cousin, brother etc

6. Does your child have any other diagnosed health conditions or disabilities other than cerebral palsy? (If yes please specify below.)

$\square$ Yes $\square$ No

$\square$ Autism

$\square$ Developmental delay

Nerve deafness

$\square$ Epilepsy

$\square$ Genetic conditions e.g. Down syndrome, spina bifida (please specify)

$\square$ Congenital conditions of brain or elsewhere e.g. Heart defect (please specify)

$\square$ Other (please specify) 


\begin{tabular}{|c|}
\hline MOTHER'S INFORMATION \\
\hline Mothers: please complete the following details about yourself: \\
\hline Your date of birth : ${ }^{\prime}{ }^{\prime}{ }^{\prime}$ \\
\hline Height $\square \square \square$ (cms) or $\square, \square \square$ (feet/inches) \\
\hline Approximate weight at beginning of pregnancy $\square \square \square($ (kgs) or $\square \square, \square \square$ (stones/pounds) \\
\hline $\begin{array}{l}\text { Race } \\
\square \text { Caucasian i.e. of European/white origin } \\
\square \text { Aboriginal } \\
\square \text { Other }\end{array}$ \\
\hline $\begin{array}{l}\text { Was your mother Caucasian? } \\
\text { Was your father Caucasian? }\end{array}$ \\
\hline $\begin{array}{l}\text { Is your child's father Caucasian? } \\
\text { If known, was your child's father's mother Caucasian? } \\
\text { If known, was your child's father's father Caucasian? }\end{array}$ \\
\hline Pregnancy Outcomes - before the birth of your enrolled child \\
\hline Number of miscarriages (less than 20 weeks of pregnancy) before the birth of your enrolled child \\
\hline \multirow{2}{*}{$\begin{array}{l}\text { Number of pregnancies (more than } 20 \text { weeks of pregnancy) before the birth of your enrolled child } \\
\text { Number of children living beyond } 1 \text { month, born before the birth of your enrolled child }\end{array}$} \\
\hline \\
\hline PREGNANCY OF THIS CHILD \\
\hline Please complete the following details about yourself during the pregnancy of this child: \\
\hline $\begin{array}{ll}\text { Tobacco Smoking } & \text { Recreational drugs during pregnancy e.g. marijuana } \\
\square \text { Non-smoker } & \square \text { Yes } \square \text { No } \\
\square \text { Smoked during pregnancy } & \end{array}$ \\
\hline $\begin{array}{ll}\square \text { less than } 1 \text { glass/week } & \square 3-4 \text { glasses/week } \\
\square \text { 1-2 glasses/week } & \square 5 \text { or more glasses/week }\end{array}$ \\
\hline $\begin{array}{l}\text { Did you have an ultrasound in the first trimester of this pregnancy? } \square \text { Yes } \square \text { No } \\
\text { If Yes, please state the number of fetuses detected }\end{array}$ \\
\hline $\begin{array}{l}\text { Medical conditions present during this pregnancy: } \\
\square \text { None } \\
\square \text { Anaemia } \\
\square \text { Urinary tract infection } \\
\square \text { High blood pressure } \\
\square \text { Diabetes } \\
\square \text { Epilepsy } \\
\square \text { Asthma } \\
\square \text { Major abdominal trauma during pregnancy e.g. due to road traffic accident, fall or assault } \\
\square \text { Other (specify) }\end{array}$ \\
\hline $\begin{array}{l}\text { Obstetric Complications } \\
\square \text { None } \\
\square \text { Bleeding } 1^{\text {st }} \text { half of pregnancy } \\
\square \text { Bleeding } 2^{\text {nd }} \text { half of pregnancy }\end{array}$ \\
\hline
\end{tabular}




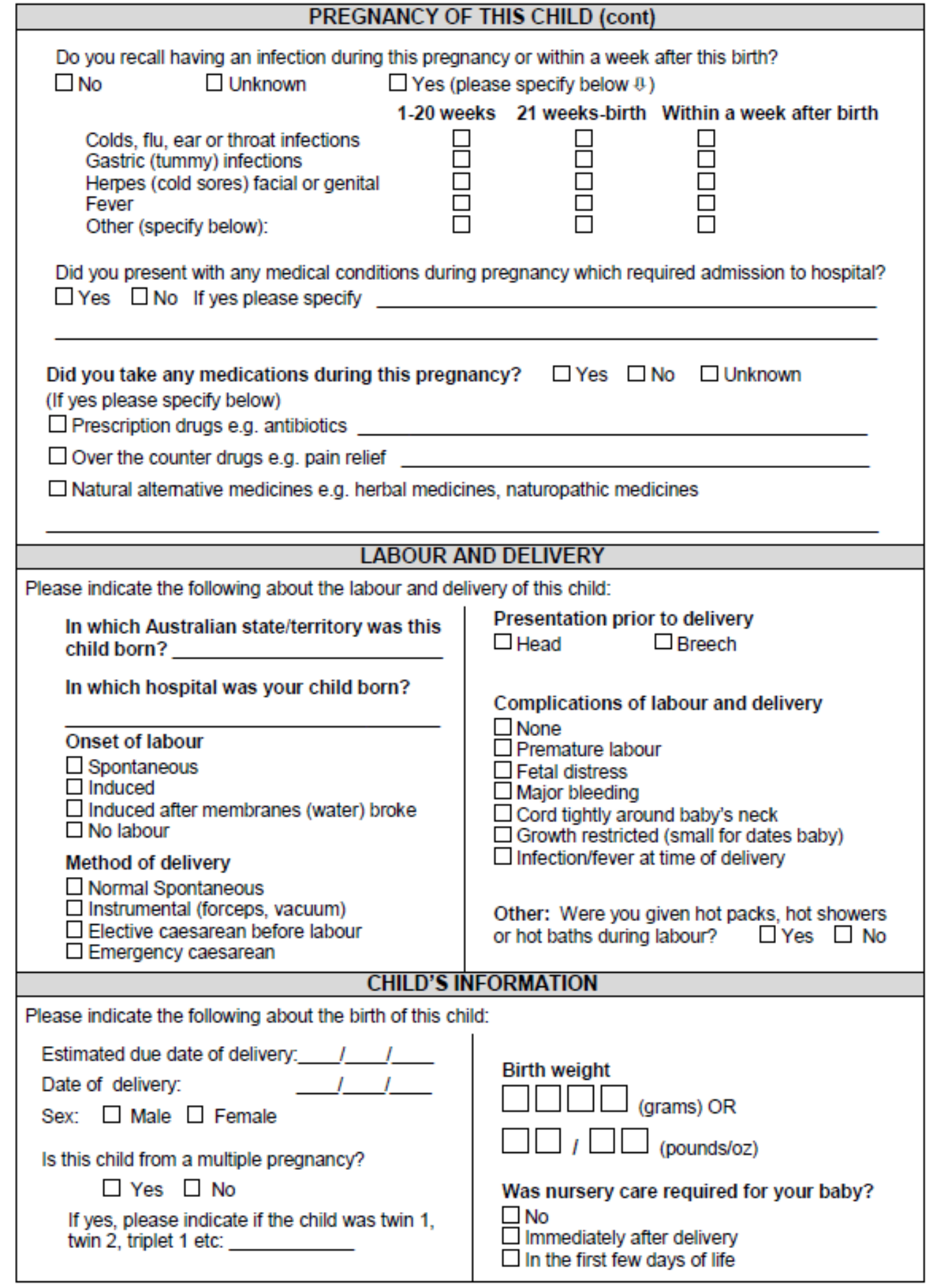




\section{Chapter 2 Study Protocol and Hypotheses}

\section{Perinatal outcomes statistics unit (POSU) data linkage}

Data links were made to the POSU data in each state to access birth details. Participants provided written informed consent to this linkage and supplied sufficient details to allow an accurate link to be made. Details returned provided confirmation of neonatal data collected in the questionnaire (e.g. birth weight, mode of delivery) and provided extra clinical information not sought from participants (such as Apgar scores and reasons for caesarean section or induced delivery). The fields returned by each state differed slightly - fields are listed in full for comparison in Table 4. 


\section{Table 4}

Perinatal data fields requested in each sate and territory of Australia.

\begin{tabular}{|c|c|c|c|c|c|c|c|}
\hline Data Group & SA & NSW & VIC & QLD & WA & TAS & ACT \\
\hline Mothers information & Mothers DOB & Mother's DOB & Birth date & Mother's DOB & Mothers DOB & Mother's DOB & Mothers DOB \\
\hline & Race & Indigenous status & Aboriginal & Indigenous status & Ethnic origin & Indigenous status & Indigenous status \\
\hline & Country of birth & Country of birth & Country (state) of birth & Country of birth & Country of birth & Country of birth & Country of birth \\
\hline & Postcode & Postcode & Postcode & Post code & Postcode & Postcode & Postcode \\
\hline & Plurality & & & & & Plurality & \\
\hline This pregnancy & $\begin{array}{l}\text { Date of last menstrual } \\
\text { period }\end{array}$ & Date of LMP & Date of LMP & LMP & Date of LMP & $\begin{array}{l}\text { Estimated date of } \\
\text { confinement }\end{array}$ & $\begin{array}{l}\text { Date of last menstrual } \\
\text { period }\end{array}$ \\
\hline & & & & & This date certain? & Determined by & \\
\hline & & & $\begin{array}{l}\text { Estimated gestation } \\
\text { (weeks) }\end{array}$ & & Expected due date & & \\
\hline & $\begin{array}{l}\text { Tobacco smoking status at } \\
\text { 1st visit }\end{array}$ & $\begin{array}{l}\text { Did the mother smoke at } \\
\text { all during this pregnancy }\end{array}$ & & $\begin{array}{l}\text { Average no. tobacco cig } \\
\text { smoked/day in } 2 \text { nd half of } \\
\text { pregnancy }\end{array}$ & $\begin{array}{l}\text { Average no. tobacco cig } \\
\text { smoked/day in } 2 \text { nd half of } \\
\text { pregnancy }\end{array}$ & $\begin{array}{l}\text { Average no. tobacco cig } \\
\text { smoked/day in } 2 \text { nd half of } \\
\text { pregnancy }\end{array}$ & $\begin{array}{l}\text { Average no. tobacco cig } \\
\text { smoked/day in } 2 \text { nd half of } \\
\text { pregnancy }\end{array}$ \\
\hline & $\begin{array}{l}\text { Average no. tobacco cig } \\
\text { smoked/day in } 2 \text { nd half of } \\
\text { pregnancy }\end{array}$ & $\begin{array}{l}\text { Average no. tobacco cig } \\
\text { smoked/day in } 2 \text { nd half of } \\
\text { pregnancy }\end{array}$ & & & Smoking during pregnancy & $\begin{array}{l}\text { During this pregnancy, } \\
\text { smoked? }\end{array}$ & $\begin{array}{l}\text { Did mother smoke during } \\
\text { pregnancy? }\end{array}$ \\
\hline & & & & & & Alcohol? & $\begin{array}{l}\text { Alcohol consumption } \\
\text { during pregnancy }\end{array}$ \\
\hline & & & & & & Marijuana? & $\begin{array}{l}\text { Was substance use } \\
\text { documented? }\end{array}$ \\
\hline & & & & & & Other recreational drugs? & Onset and type of labour \\
\hline
\end{tabular}




\begin{tabular}{|c|c|c|c|c|c|c|c|}
\hline Data Group & SA & NSW & VIC & QLD & WA & TAS & ACT \\
\hline & $\begin{array}{l}\text { Medical conditions } \\
\text { present in this pregnancy }\end{array}$ & Medical conditions & $\begin{array}{l}\text { Maternal medical } \\
\text { conditions }\end{array}$ & $\begin{array}{l}\text { Current Medical } \\
\text { Conditions }\end{array}$ & Medical conditions & & $\begin{array}{l}\text { Medical conditions whilst } \\
\text { pregnant }\end{array}$ \\
\hline \multirow[t]{5}{*}{ This pregnancy } & Obstetric complications & & Obstetric complications & Pregnancy complications & $\begin{array}{c}\text { Complications of } \\
\text { pregnancy }\end{array}$ & Obstetric complications & $\begin{array}{c}\text { Complications of } \\
\text { pregnancy }\end{array}$ \\
\hline & & & & Assisted conception & & $\begin{array}{l}\text { Pregnancy result of } \\
\text { assisted repro tech }\end{array}$ & \\
\hline & & & & Height & & & Gravidy, parity \\
\hline & & & & EDC & & & \\
\hline & & & & Actual place of birth & & & \\
\hline \multirow[t]{8}{*}{ Labour \& delivery } & Onset of labour & Onset of labour & Labour & Onset of labour & Onset of labour & Labour & $\begin{array}{l}\begin{array}{l}\text { Complications of labour } 8 \\
\text { birth }\end{array} \\
\text { (a) }\end{array}$ \\
\hline & $\begin{array}{l}\text { If induction, or } \\
\text { augmentation, methods }\end{array}$ & $\begin{array}{l}\text { If labour } \\
\text { augmented/induced }\end{array}$ & $\begin{array}{l}\text { If labour induced or } \\
\text { augmented }\end{array}$ & $\begin{array}{l}\text { Which used to induce } \\
\text { labour }\end{array}$ & Augmentation & Method of induction & \\
\hline & & $\begin{array}{l}\text { If labour induced, main } \\
\text { indication }\end{array}$ & $\begin{array}{l}\text { Specify indication for } \\
\text { induction }\end{array}$ & $\begin{array}{l}\text { If labour induced, reason } \\
\text { for induction }\end{array}$ & Induction & $\begin{array}{l}\text { Indication for induction of } \\
\text { labour }\end{array}$ & \\
\hline & $\begin{array}{l}\text { Presentation prior to } \\
\text { delivery }\end{array}$ & Presentation at birth & Presentation & Membranes ruptured & Presentation & $\begin{array}{l}\text { Presentation at vaginal } \\
\text { brith }\end{array}$ & Presentation \\
\hline & Method of delivery & Type of delivery & Type of birth & Place of birth & Place of birth & Place of birth & Place of birth \\
\hline & $\begin{array}{l}\text { Complications of labour, } \\
\text { delivery \& puerperim }\end{array}$ & & & Length of labour & Method of birth & Mode of birth & Method of birth \\
\hline & & & & Method of birth & & Elective CS & \\
\hline & & & & Reason for CS & & Indication for CS & \\
\hline
\end{tabular}




\begin{tabular}{|c|c|c|c|c|c|c|c|}
\hline Data Group & SA & NSW & VIC & QLD & WA & TAS & ACT \\
\hline Labour \& delivery & & & $\begin{array}{l}\text { Complication of labour, } \\
\text { birth or postnatal }\end{array}$ & $\begin{array}{l}\text { Labour and delivery } \\
\text { complications }\end{array}$ & $\begin{array}{l}\text { Complications of labour } \\
\text { and delivery }\end{array}$ & $\begin{array}{l}\text { Labour \& delivery } \\
\text { complications }\end{array}$ & \\
\hline & & & & & Duration of labour & & \\
\hline & & & & & & Augmentation of labour & Augmented \\
\hline & & & & & & & Method \\
\hline & & & & & & & $\begin{array}{l}\text { Reason for augmentation } \\
\text { or induction }\end{array}$ \\
\hline Baby details & Place of birth & Place of birth & & & & Actual place of birth & \\
\hline & Date of delivery & Birth date & Birth date & DOB & Birth date & $\mathrm{DOB}$ & Birth date \\
\hline & Sex & Sex & Sex & & Gender & Sex & Sex \\
\hline & Birth weight & Birth weight & Birth weight & Birth weight & Infant weight & Weight & Birth weight \\
\hline & Gestation at birth & Estimated gestational age & & Gestation & Estimated gestation & Gestational age at birth & Gestational age \\
\hline & & Plurality & Plurality & Plurality & Plurality & & \\
\hline & & & & & & Birth order & Birth order \\
\hline Condition at birth & Apgar score & Apgar & Apgar & Apgar score & Apgar score & Apgar score & Apgar score \\
\hline & $\begin{array}{l}\text { Time to establish regular } \\
\text { breathing }\end{array}$ & & $\begin{array}{l}\text { Time to established } \\
\text { respiration }\end{array}$ & Regular respirations & $\begin{array}{l}\text { Time to establish } \\
\text { unassisted } \\
\text { breathing }\end{array}$ & & \\
\hline & Resuscitation at delivery & Resuscitation of baby & Resuscitation & Resuscitation & & Resuscitation at birth & $\begin{array}{l}\text { Resuscitation - active } \\
\text { methods }\end{array}$ \\
\hline Condition at birth & $\begin{array}{ll}\text { Condition } & \text { occurring } \\
\text { during birth } & \end{array}$ & & & & & & $\begin{array}{l}\text { Resuscitation - drug } \\
\text { therapy }\end{array}$ \\
\hline & Nursery care required & Admitted to NICU & Admitted to NICU & $\begin{array}{l}\text { Was baby admitted to } \\
\text { ICN/SCN }\end{array}$ & & $\begin{array}{l}\text { Medical admission to } \\
\text { SCN/ICU }\end{array}$ & Admission to SCN/NICU \\
\hline
\end{tabular}




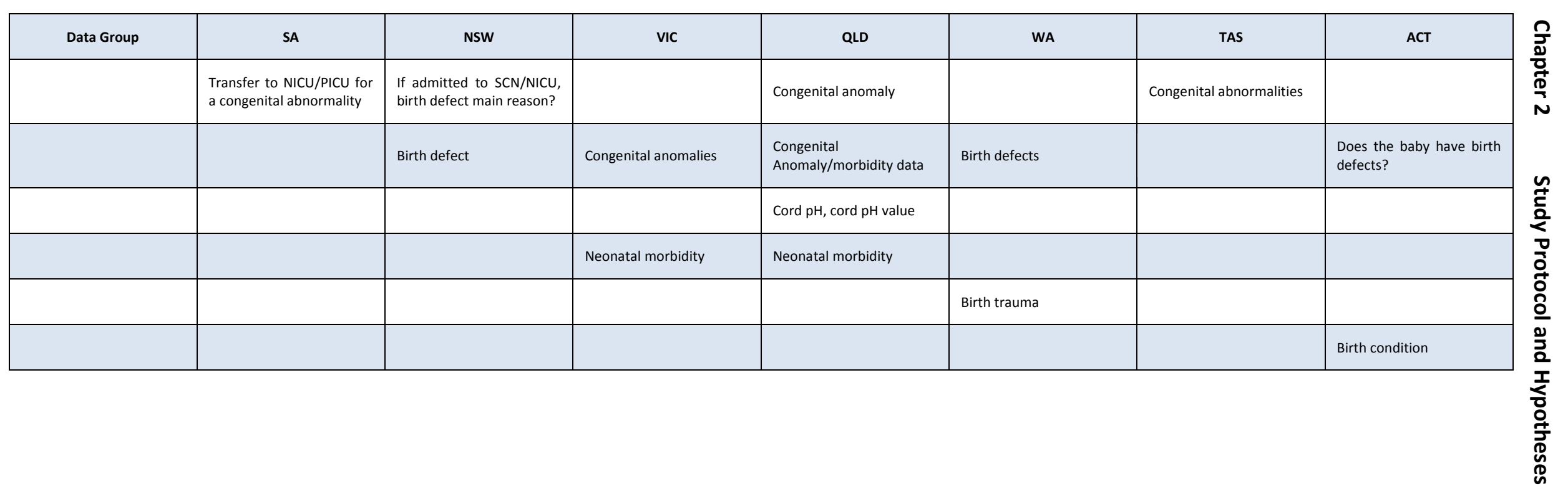




\section{Chapter 2 Study Protocol and Hypotheses}

\section{Cerebral palsy register data linkage}

Data links were made to cerebral palsy register data in each state to confirm diagnosis and access details about cerebral palsy subtype (diplegia, hemiplegia, quadriplegia or other cerebral palsy types). For cases not included on a register, confirmation of diagnosis and clinical details were sought from the child's primary specialist. 
Chapter 2 Study Protocol and Hypotheses

\section{Analysis}

\section{Potential biases}

As this cohort has been prospectively recruited, there may be recruitment bias in both the case and control cohorts. Cohort biases will be assessed for cases and controls for genotype frequencies, perinatal data and diagnostic subgroups of cerebral palsy by comparison with previously published population based data.

\section{Statistical methods}

Univariable analysis

The following will be examined initially by univariate analyses for association with fetal cerebral palsy outcome:

Fetal SNP carriage

Maternal SNP carriage

Epidemiological risk factors -

Maternal infection during pregnancy

Intrauterine growth restriction (using customised percentiles)

Gestational age

Multiple birth

Siblings or parents with cerebral palsy

Breech position

“Disappearing twin" on ultrasound

Use of heat in labour

Ante-partum haemorrhage 


\section{Chapter 2 Study Protocol and Hypotheses}

Diabetes

Maternal body mass index

Pregnancy hypertension

Nuchal cord or cord enlargement

Smoking, alcohol consumption and drug abuse

Anaemia

Maternal thyroid disorder

Where significant associations are found, sub-analyses will be conducted, stratifying the cohort by cerebral palsy subtype (quadriplegia, diplegia or hemiplegia) along with gestational age (<32 weeks GA, 32-36 weeks GA, $\geq 37$ weeks GA). These analyses will serve to test previously reported SNP associations in an independent cohort and also allow the opportunity to test previously reported associations between SNP carriage and cerebral palsy subtype and specific gestational ages.

Cerebral palsy is a heterogeneous condition with patients exhibiting a variety of motor defects along with differing levels of severity. It is possible that that the clinical subtypes of the condition are the result of different causal pathways and this may be reflected in different SNP and epidemiological associations. A number of papers have considered this factor and included analysis of cerebral palsy subtypes in their reports 446425414 . Thus far, the strongest association of this type appears to be between hemiplegic cerebral palsy and thrombophilic SNP carriage.

Conducting numerous sub-analyses has been a key weakness of studies to date and is likely to be a limiting factor in the present study. To reduce the risk of type I and type II error, analysis will utilise 1) a higher level of probability to detect significance (Bonferroni correction), 


\section{Chapter 2 Study Protocol and Hypotheses}

2) a priori selection of candidate genes and clinical risk factors, 3) a new prospective cohort and

4) a large sample size to help reduce type II error.

Multivariable analysis

Testing specific hypothesised pathways of cerebral palsy causation such as thrombophilic SNPs with late gestational age leading to hemiplegia or inflammatory SNPs with early gestational age leading to quadriplegia will form the initial multivariate analysis. Significant associations ( $p \leq 0.01$ in univariate analysis) will be used in a multivariate analysis by means of logistic regression, initially examining only genetic associations with cerebral palsy, but then in combination with individual epidemiological data and their interactions.

\section{Timeline}

Recruitment commenced in July 2008 and continued for 21 months until March 2010. Recruitment of 840 case and 1,320 control families was achieved over this period.

\section{Summary}

The protocol outlined addresses the need for large studies examining both fetal and maternal SNP associations with fetal cerebral palsy outcome. The study also provides an avenue for investigation of clinical and genetic associations and is designed to confirm or reject previously reported associations as well as investigate new interactions with possible clinical triggers for cerebral palsy. 
Chapter 3 Cohort Demographics

Chapter 3 Cohort Demographics 
Chapter 3

Cohort Demographics 


\section{Chapter 3 Cohort Demographics}

\section{Abstract \\ Introduction}

This chapter describes the demographic features of the case and control cohorts recruited for the Australian Cerebral Palsy Research Study.

\section{Inclusion exclusion criteria for data analysis}

Buccal swabs were provided by 2,169 families during the recruitment period while analysis was conducted on 1,741 families. The reasons for excluding families from the analysis including age of child, country of birth and ethnicity are outlined.

\section{Cohort descriptions}

Case and control cohorts are described by state of birth, source of recruitment, birth year, gender, gestational age, birth weight, Apgar scores at 1 and 5 minutes, plurality, maternal age, type of delivery and birth weight centile. Statistical comparisons between case and control cohorts are made in chapter 6 .

\section{Assessment of control cohort bias}

To assess potential biases in the control cohort, comparisons are made with Australian population data (birth year 2007) for gender, gestational age, birth weight, Apgar score, plurality, maternal age and type of delivery with statistical comparison where appropriate.

\section{Assessment of case cohort bias}

To assess potential biases in the case cohort comparisons were made to population data from the Australian Cerebral Palsy Register considering gender, gestational age, birth weight, plurality, maternal age, cerebral palsy subtype and GMFCS level with statistical comparison where approproriate. 


\section{Chapter 3 Cohort Demographics}

\section{Quality control of genotype data}

Each SNP was assessed for Mendelian errors and genotype calls from mother and child were excluded where they were inconsistent with the expected pattern of inheritance $(<1 \%)$. Participant data was excluded from analysis if a sibling was enrolled in the study (8 families), genotype data for Amelogenin, a Y chromosome SNP, was inconsistent (e.g. the presence of a $Y$ chromosome detected in a DNA sample indicated to be a female on the questionnaire) with gender reported in the questionnaire (12 families) or had a SNP failure rate of $>25 \%$ over the panel of 39 SNPs (23 families). The genotyping success rate of each SNP was assessed and all were $>93 \%$ complete. No differences were seen between cases and controls. Hardy Weinberg equilibrium for each SNP was assessed and those statistically different from the expected distribution were excluded ( $p<0.05,1$ SNP).

\section{Quality control of questionnaire data}

Ten percent of maternal questionnaires and consent forms were randomly selected to assess data entry errors by a member of the research team. One per cent of data elements contained errors.

\section{Conclusions}

The cohort of the Australian Cerebral Palsy Research Study comprises Caucasian children born in Australia between 1990 and 2005 both with and without cerebral palsy and generally represents these populations well. Caution needs to be used when extrapolating the results of this study to the wider population as there are statistical differences between the control cohort and the Australian population and also between the case cohort and the Australian cerebral palsy population, though these are unlikely to be of clinical importance. The genotypic and questionnaire data have been assessed for quality and are suitable to assess the hypotheses detailed in chapter 2 . 
Chapter 3

Cohort Demographics 


\section{Chapter 3 Cohort Demographics}

\section{Inclusion exclusion criteria for data analysis}

The Australian Cerebral Palsy Research Study cohort was recruited as described in chapter 2 between 3 July 2008 and 31 March 2010. Buccal swab DNA samples were returned from 2,169 families during this period, however not all families met the recruitment criteria. Figure 1 summarises the reason families were excluded from this initial cohort to leave a final cohort of 1,741 families (1,154 controls and 587 cases). This cohort excluded cases born in South Australia between the years 1986 and 1999 and is therefore independent of the cohort previously examined by Gibson et al 3, 5, 6, 14, 42, 93, 94. 


\section{Chapter 3 Cohort Demographics}

\section{Figure 1}

Inclusion and exclusion criteria for The Australian Cerebral Palsy Research Study. NB numbers cited refer to participating families and each represents a mother child pair. The previous cohort referred to ${ }^{3,5,6,14,42,93,94}$ includes birth years 1986-1999 in South Australia.

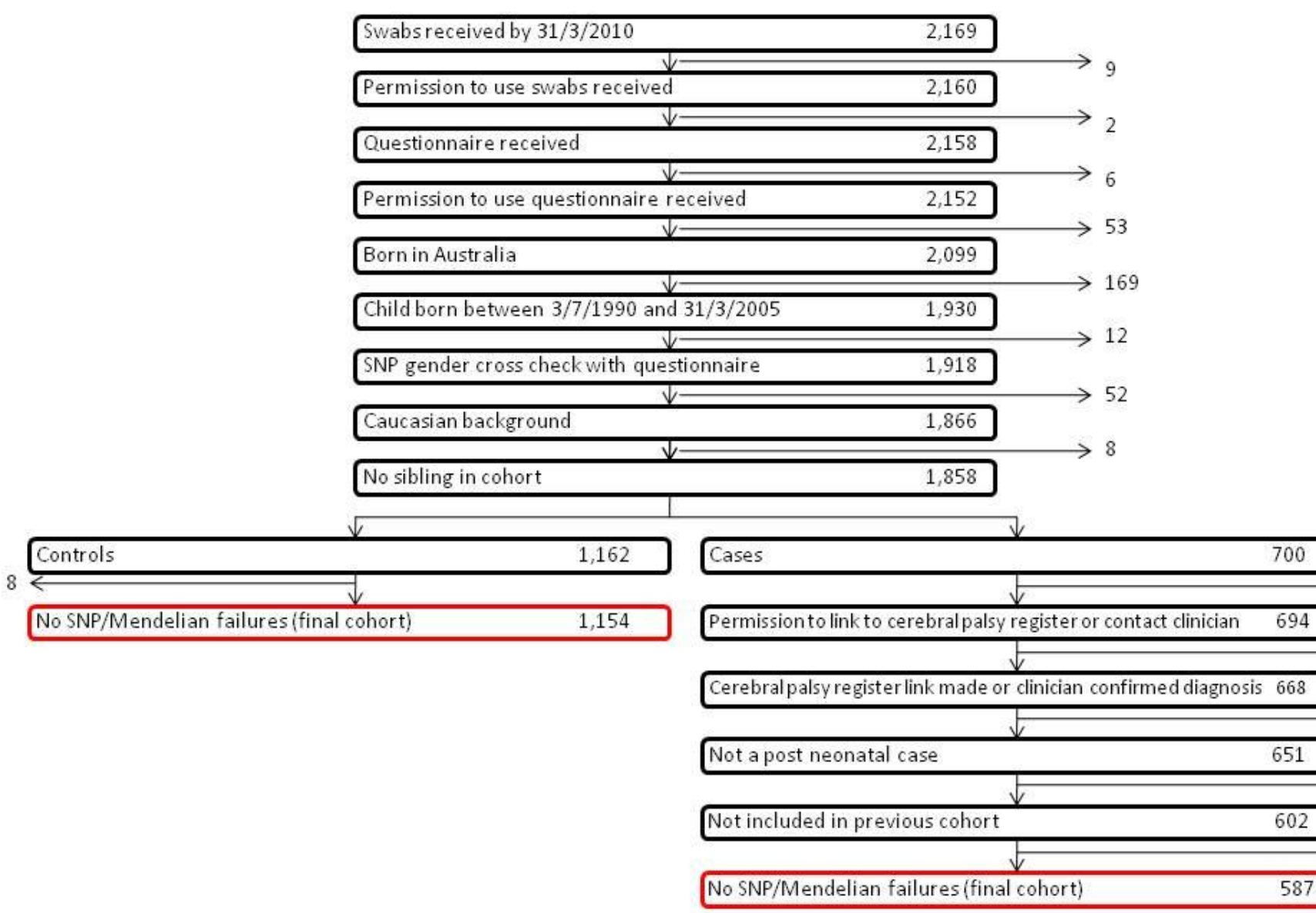

The cohort was of a suitable size to obtain the power described in chapter 2 and is therefore suitable for an initial test of the proposed hypotheses. 


\section{Cohort descriptions}

The case and control cohorts are described detailing their source and key clinical features. This chapter provides the demography of the cohort with statistical comparisons between cases and controls made in chapter 6 .

\section{Distribution by state}

Case-control studies require that each cohort is drawn from the same population. For this study, Caucasian cases and controls aged between 5 and 18 years were drawn from each State and Territory in Australia with the proportion from each state shown in Figure 2 and Table 1. South Australia is over represented in the control cohort and the effect of this and other biases is assessed by comparing Perinatal data with the Australian wide population data later in this chapter.

\section{Figure 2}

Cohort distribution by Australian State/Territory

\section{Cohort Distribution by State}

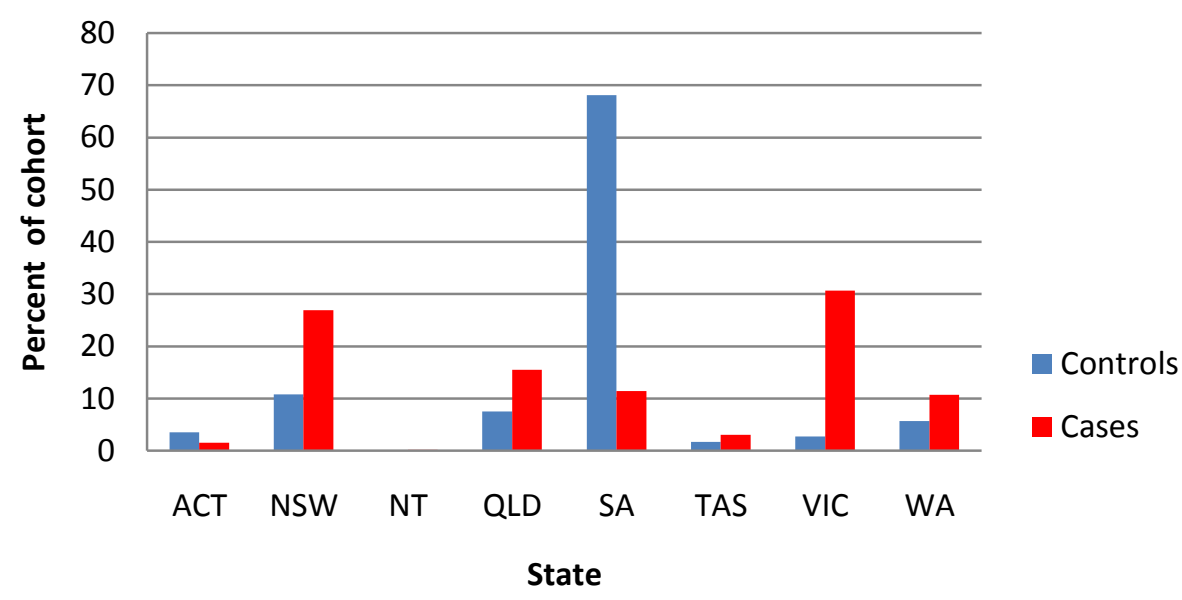




\section{Chapter 3 Cohort Demographics}

Table 1

Cohort distribution by Australian State/Territory

\begin{tabular}{|c|c|c|c|c|}
\hline \multirow[b]{2}{*}{$\begin{array}{l}\text { State of } \\
\text { recruitment }\end{array}$} & \multicolumn{2}{|c|}{ Controls } & \multicolumn{2}{|c|}{ Cases } \\
\hline & Number & $\%$ of cohort & Number & $\%$ of cohort \\
\hline ACT & 41 & 4 & 9 & 2 \\
\hline NSW & 124 & 11 & 158 & 27 \\
\hline NT & 1 & 0 & 1 & 0 \\
\hline QLD & 87 & 8 & 91 & 16 \\
\hline SA & 786 & 68 & 67 & 11 \\
\hline TAS & 19 & 2 & 18 & 3 \\
\hline VIC & 31 & 3 & 180 & 31 \\
\hline WA & 65 & 6 & 63 & 11 \\
\hline Total & 1154 & 100 & 587 & 100 \\
\hline
\end{tabular}




\section{Source of cohort recruitment}

Recruitment of volunteers took place using the strategies outlined in chapter 2 . The majority of cases were drawn from cerebral palsy registers while most controls were recruited through schools and community booths in shopping malls and at the Royal Adelaide Show. Support groups (e.g. The Spastic Centre, Novita et al) and media advertising (internet advertising provided by Rewards for Research Pty Ltd, Brisbane Australia) supplemented recruitment for both cases and controls. Recruitment achieved through each source is detailed in Figure 3 and Table 2.

\section{Figure 3}

Source of cohort recruitment

\section{Source of Recruits}

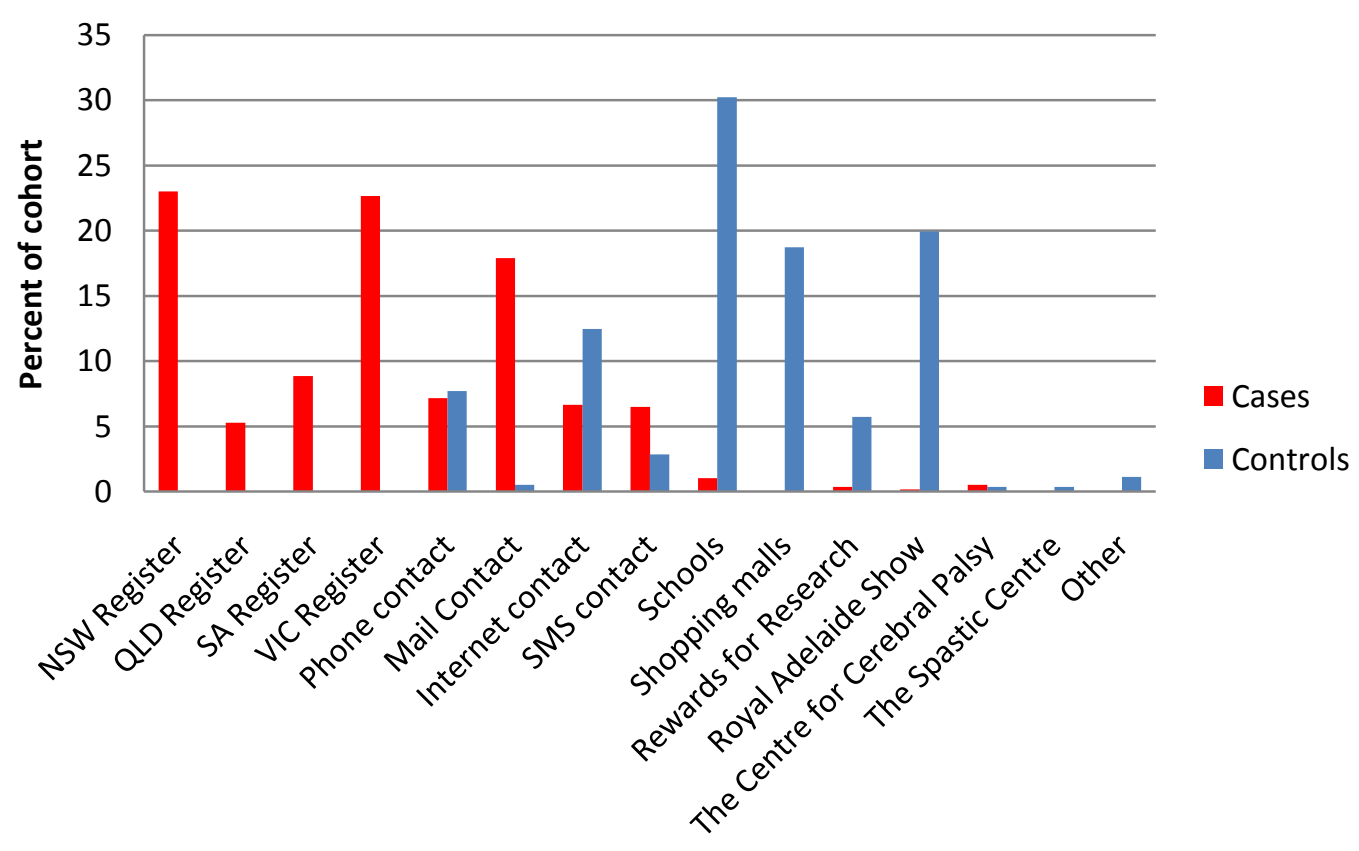

Source of recruits 


\section{Chapter 3 Cohort Demographics}

Table 2

Source of cohort recruitment.

\begin{tabular}{|c|c|c|c|c|}
\hline \multirow[b]{2}{*}{ Source of recruits } & \multicolumn{2}{|c|}{ Cases } & \multicolumn{2}{|c|}{ Controls } \\
\hline & Number & $\%$ of cohort & Number & $\%$ of cohort \\
\hline NSW Register & 135 & 23 & 0 & 0 \\
\hline QLD Register & 31 & 5 & 0 & 0 \\
\hline SA Register & 52 & 9 & 0 & 0 \\
\hline VIC Register & 133 & 23 & 0 & 0 \\
\hline Phone contact & 42 & 7 & 89 & 8 \\
\hline Mail Contact & 105 & 18 & 6 & 1 \\
\hline Internet contact & 39 & 7 & 144 & 12 \\
\hline SMS contact & 38 & 6 & 33 & 3 \\
\hline Schools & 6 & 1 & 349 & 30 \\
\hline Shopping malls & 0 & 0 & 216 & 19 \\
\hline Rewards for Research & 2 & 0 & 66 & 6 \\
\hline Royal Adelaide Show & 1 & 0 & 230 & 20 \\
\hline The Centre for Cerebral Palsy & 3 & 1 & 4 & 0 \\
\hline The Spastic Centre & 0 & 0 & 4 & 0 \\
\hline Other & 0 & 0 & 13 & 1 \\
\hline Total & 587 & 100 & 1154 & 100 \\
\hline
\end{tabular}




\section{Birth year of cohort}

Children recruited as cases or controls were required to be aged between 5 and 18 years during the period of recruitment. This corresponded to birth dates between 3/7/1990 and 31/3/2005. Figure 4 and Table 3 show the distribution of birth years with cases being on average born in 1997 and controls in 1999. The reason of this disparity is unknown.

\section{Figure 4}

Birth year of cohort

\section{Birth Year Distribution}

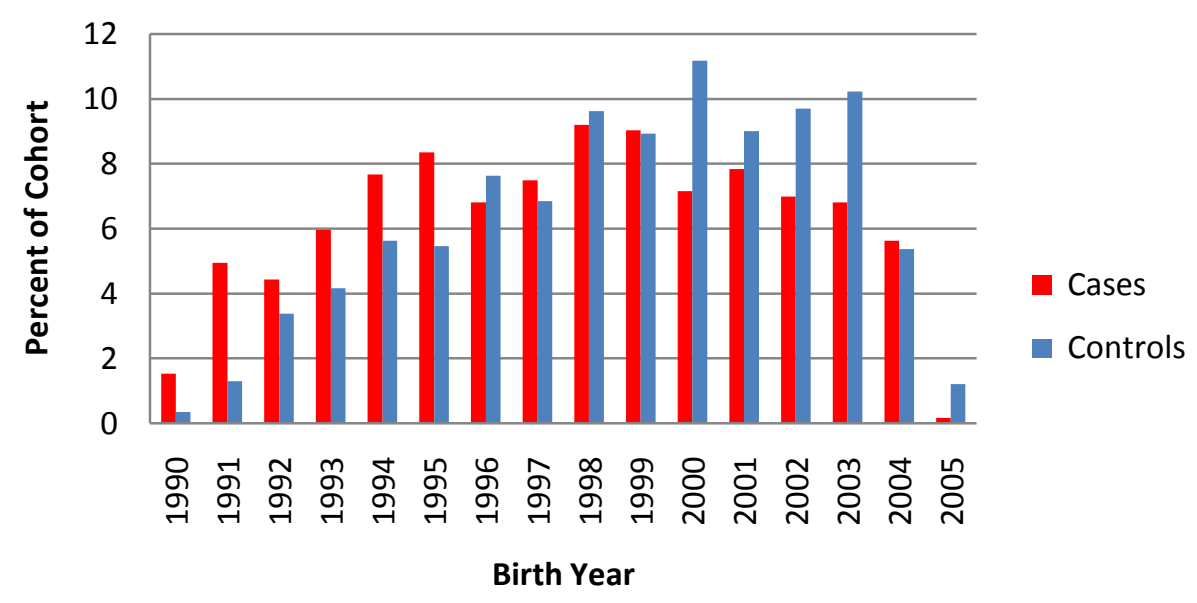


Chapter 3 Cohort Demographics

Table 3

Birth year of cohort.

\begin{tabular}{|c|c|c|c|c|}
\hline \multirow[b]{2}{*}{ Birth Year } & \multicolumn{2}{|c|}{ Cases } & \multicolumn{2}{|c|}{ Controls } \\
\hline & Number & $\%$ of cohort & Number & $\%$ of cohort \\
\hline 1990 & 9 & 1.5 & 4 & 0.3 \\
\hline 1991 & 29 & 4.9 & 15 & 1.3 \\
\hline 1992 & 26 & 4.4 & 39 & 3.4 \\
\hline 1993 & 35 & 6.0 & 48 & 4.2 \\
\hline 1994 & 45 & 7.7 & 65 & 5.6 \\
\hline 1995 & 49 & 8.3 & 63 & 5.5 \\
\hline 1996 & 40 & 6.8 & 88 & 7.6 \\
\hline 1997 & 44 & 7.5 & 79 & 6.8 \\
\hline 1998 & 54 & 9.2 & 111 & 9.6 \\
\hline 1999 & 53 & 9.0 & 103 & 8.9 \\
\hline 2000 & 42 & 7.2 & 129 & 11.2 \\
\hline 2001 & 46 & 7.8 & 104 & 9.0 \\
\hline 2002 & 41 & 7.0 & 112 & 9.7 \\
\hline 2003 & 40 & 6.8 & 118 & 10.2 \\
\hline 2004 & 33 & 5.6 & 62 & 5.4 \\
\hline 2005 & 1 & 0.2 & 14 & 1.2 \\
\hline Total & 587 & 100 & 1154 & 100 \\
\hline
\end{tabular}




\section{Chapter 3 Cohort Demographics}

\section{Gender distribution}

Figure 5 and Table 4 show the distribution of genders between cases and controls.

\section{Figure 5}

Gender distribution of cohort

\section{Gender Distribution}

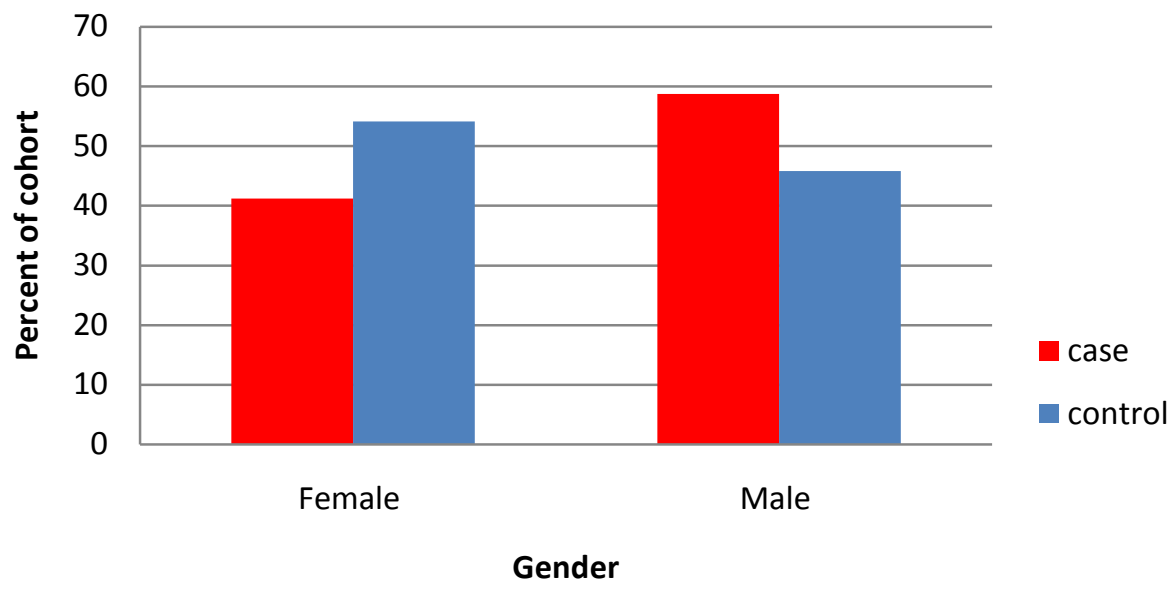

Table 4

Gender distribution of cohort.

\begin{tabular}{|c|c|c|c|c|}
\hline \multirow{2}{*}{ Gender } & \multicolumn{2}{|c|}{ Cases } & \multicolumn{2}{c|}{ Controls } \\
\hline Male & Number & $\%$ & Number & 46 \\
\hline Female & 345 & 58 & 529 & 54 \\
\hline Total & 242 & 42 & 625 & 100 \\
\hline
\end{tabular}




\section{Gestational age distribution}

Figure 6 and Table 5 show the distribution of gestational ages between cases and controls. The mean gestational age for cases was $35.3(35.7-34.995 \% \mathrm{Cl})$ weeks and for controls $39.3(39.2-39.495 \% \mathrm{Cl})$ weeks.

\section{Figure 6}

Gestational age distribution of cohort

\section{Gestational Age Distribution}

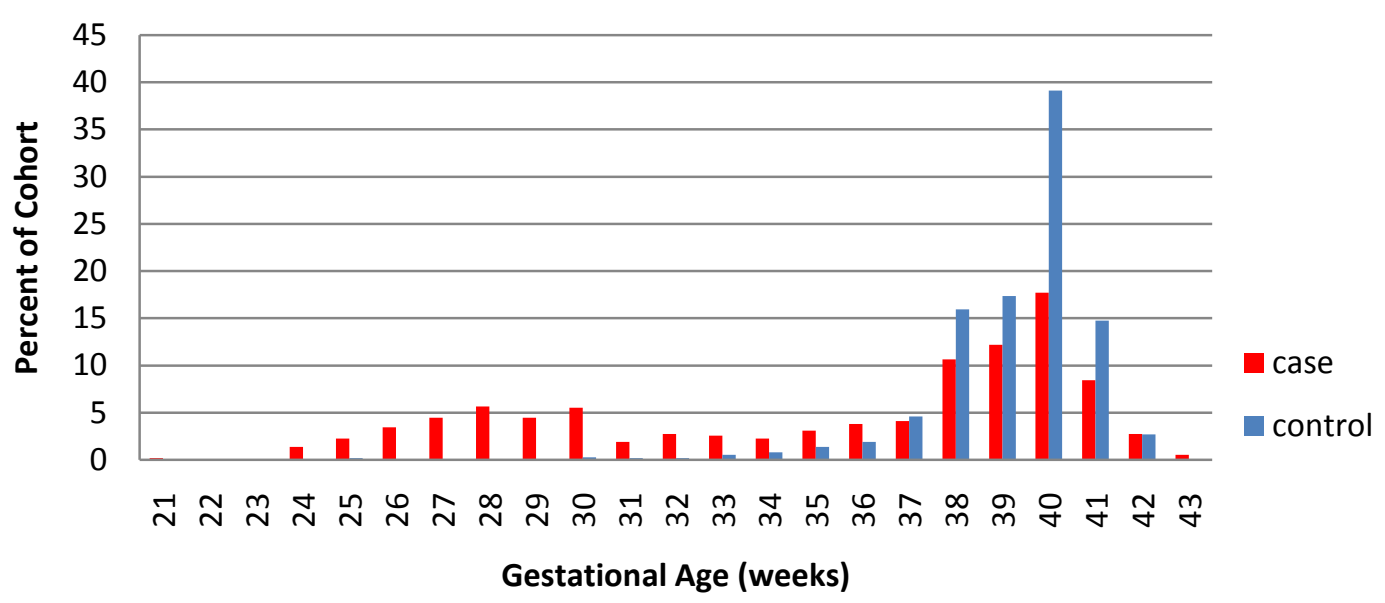




\section{Chapter 3 Cohort Demographics}

Table 5

Gestational age distribution of cohort.

\begin{tabular}{|c|c|c|c|c|}
\hline \multirow[b]{2}{*}{ Weeks GA } & \multicolumn{2}{|c|}{ Cases } & \multicolumn{2}{|c|}{ Controls } \\
\hline & Number & $\%$ & Number & $\%$ \\
\hline 21 & 1 & 0.2 & 0 & 0.0 \\
\hline 22 & 0 & 0.0 & 0 & 0.0 \\
\hline 23 & 0 & 0.0 & 0 & 0.0 \\
\hline 24 & 8 & 1.4 & 0 & 0.0 \\
\hline 25 & 13 & 2.2 & 2 & 0.2 \\
\hline 26 & 20 & 3.4 & 0 & 0.0 \\
\hline 27 & 26 & 4.5 & 0 & 0.0 \\
\hline 28 & 33 & 5.7 & 1 & 0.1 \\
\hline 29 & 26 & 4.5 & 0 & 0.0 \\
\hline 30 & 32 & 5.5 & 3 & 0.3 \\
\hline 31 & 11 & 1.9 & 2 & 0.2 \\
\hline 32 & 16 & 2.7 & 2 & 0.2 \\
\hline 33 & 15 & 2.6 & 6 & 0.5 \\
\hline 34 & 13 & 2.2 & 9 & 0.8 \\
\hline 35 & 18 & 3.1 & 16 & 1.4 \\
\hline 36 & 22 & 3.8 & 22 & 1.9 \\
\hline 37 & 24 & 4.1 & 53 & 4.6 \\
\hline 38 & 62 & 10.7 & 184 & 16.0 \\
\hline 39 & 71 & 12.2 & 200 & 17.3 \\
\hline 40 & 103 & 17.7 & 451 & 39.1 \\
\hline 41 & 49 & 8.4 & 170 & 14.7 \\
\hline 42 & 16 & 2.7 & 31 & 2.7 \\
\hline 43 & 3 & 0.5 & 1 & 0.1 \\
\hline Total* & 582 & 100 & 1153 & 100 \\
\hline
\end{tabular}

* 5 cases and 1 control did not report gestational age on the maternal questionnaire and could not be linked to POSU data. 


\section{Birth weight distribution}

Figure 7 and Table 6 show the distribution of birth weights between cases and controls. The mean birth weight for cases was 2538g (2450-2626g 95\% Cl) and for controls 3456g (3424$348895 \% \mathrm{Cl})$.

\section{Figure 7}

Birth weight distribution of cohort

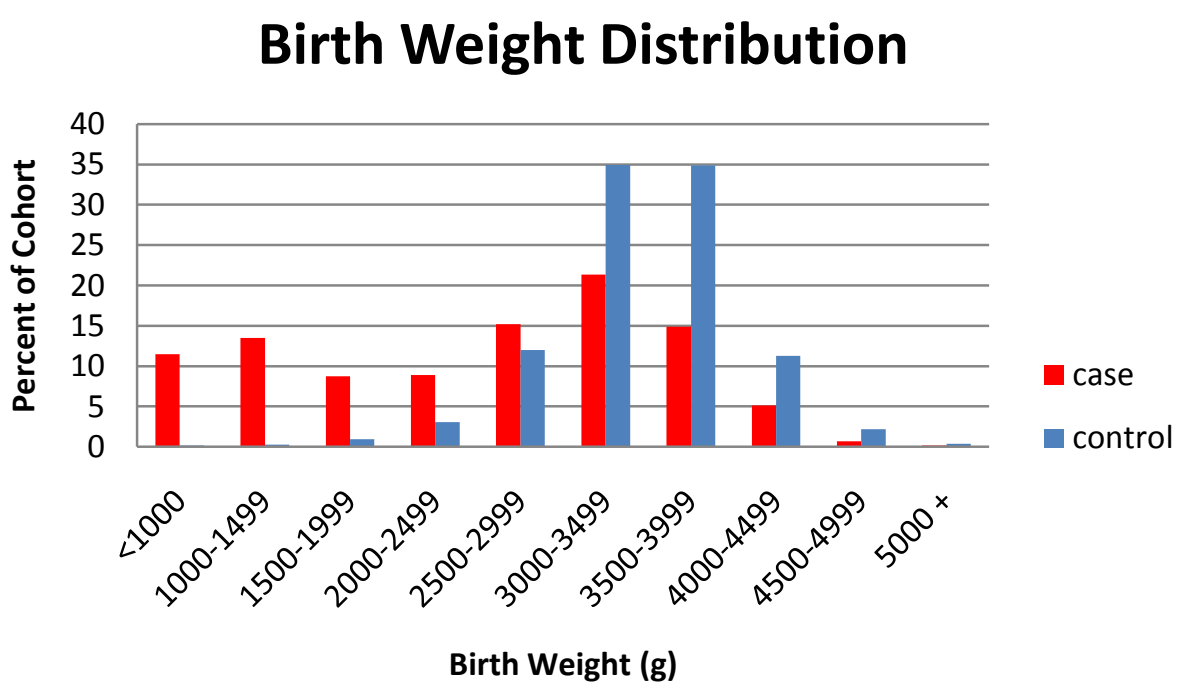




\section{Chapter 3 Cohort Demographics}

\section{Table 6}

Birth weight distribution of cohort.

\begin{tabular}{|c|c|c|c|c|}
\hline \multirow[b]{2}{*}{ Birth Weight (g) } & \multicolumn{2}{|c|}{ Cases } & \multicolumn{2}{|c|}{ Controls } \\
\hline & Number & $\%$ & Number & $\%$ \\
\hline$<1000$ & 67 & 11.5 & 2 & 0.2 \\
\hline $1000-1499$ & 79 & 13.5 & 3 & 0.3 \\
\hline 1500-1999 & 51 & 8.7 & 11 & 1.0 \\
\hline 2000-2499 & 52 & 8.9 & 35 & 3.0 \\
\hline 2500-2999 & 89 & 15.2 & 138 & 12.0 \\
\hline $3000-3499$ & 125 & 21.4 & 403 & 35.0 \\
\hline $3500-3999$ & 87 & 14.9 & 402 & 34.9 \\
\hline $4000-4499$ & 30 & 5.1 & 130 & 11.3 \\
\hline $4500-4999$ & 4 & 0.7 & 25 & 2.2 \\
\hline $5000+$ & 1 & 0.2 & 4 & 0.3 \\
\hline Total* & 585 & 100 & 1153 & 100 \\
\hline
\end{tabular}

*Note that 3 participants did not supply birth weight data by questionnaire and POSU data was also not available. For all others, POSU data was taken in preference to questionnaire data. 


\section{Apgar score distribution}

Apgar scores taken at 1 minute are shown in Figure 8 and Table 7 and those taken at 5 minutes in Figure 8 and Table 7. Median Apgar score at 1 minute was 7 for cases and 9 for controls. At 5 minutes the mean score was 9 for cases and 9 for controls.

\section{Figure 8}

Apgar score (1 minute) distribution of cohort

\section{Agpar Score (1 minute) Distribution}

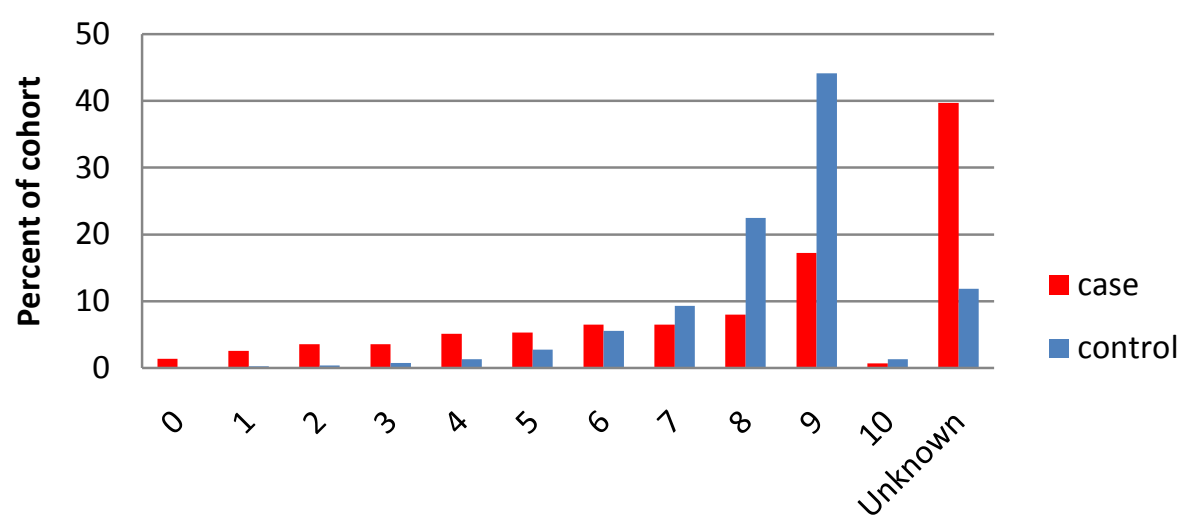

Apgar score 


\section{Chapter 3 Cohort Demographics}

Table 7

Apgar score (1 minute) distribution of cohort.

\begin{tabular}{|c|c|c|c|c|}
\hline \multirow[b]{2}{*}{ Apgar score (1 minute) } & \multicolumn{2}{|c|}{ Cases } & \multicolumn{2}{|c|}{ Controls } \\
\hline & Number & $\%$ & Number & $\%$ \\
\hline 0 & 8 & 1.4 & 0 & 0.0 \\
\hline 1 & 15 & 2.6 & 3 & 0.3 \\
\hline 2 & 21 & 3.6 & 4 & 0.3 \\
\hline 3 & 21 & 3.6 & 9 & 0.8 \\
\hline 4 & 30 & 5.1 & 15 & 1.3 \\
\hline 5 & 31 & 5.3 & 32 & 2.8 \\
\hline 6 & 38 & 6.5 & 64 & 5.5 \\
\hline 7 & 38 & 6.5 & 107 & 9.3 \\
\hline 8 & 47 & 8.0 & 259 & 22.4 \\
\hline 9 & 101 & 17.2 & 509 & 44.1 \\
\hline 10 & 4 & 0.7 & 15 & 1.3 \\
\hline Unknown* & 233 & 39.7 & 137 & 11.9 \\
\hline Total & 587 & 100 & 1154 & 100 \\
\hline
\end{tabular}

*Note that Apgar scores were only available where POSU links were made. 


\section{Figure 9}

Apgar score (5 minute) distribution of cohort.

\section{Apgar Score (5 mintue) Distribution}

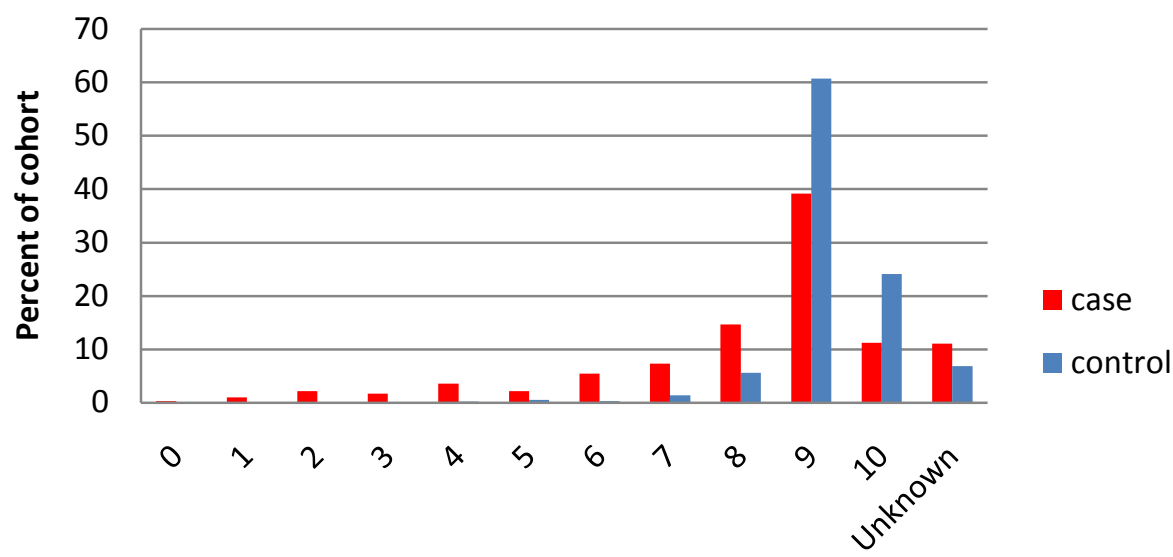

Apgar score (5 minutes) 


\section{Chapter 3 Cohort Demographics}

Table 8

Apgar score (5 minute) distribution of cohort.

\begin{tabular}{|c|c|c|c|c|}
\hline & Cases & & Controls & \\
\hline $\begin{array}{l}\text { Apgar score } \\
\text { (5 minutes) }\end{array}$ & Number & $\%$ & Number & $\%$ \\
\hline 0 & 2 & 0.3 & 0 & 0.0 \\
\hline 1 & 6 & 1.0 & 1 & 0.1 \\
\hline 2 & 13 & 2.2 & 1 & 0.1 \\
\hline 3 & 10 & 1.7 & 0 & 0.0 \\
\hline 4 & 21 & 3.6 & 3 & 0.3 \\
\hline 5 & 13 & 2.2 & 6 & 0.5 \\
\hline 6 & 32 & 5.5 & 4 & 0.3 \\
\hline 7 & 43 & 7.3 & 16 & 1.4 \\
\hline 8 & 86 & 14.7 & 65 & 5.6 \\
\hline 9 & 230 & 39.2 & 701 & 60.7 \\
\hline 10 & 66 & 11.2 & 278 & 24.1 \\
\hline Unknown* & 65 & 11.1 & 79 & 6.8 \\
\hline Total & 587 & 100 & 1154 & 100 \\
\hline
\end{tabular}

*Note that Apgar scores were only available where POSU links were made. 


\section{Chapter 3 Cohort Demographics}

\section{Plurality distribution}

Plurality of cases and controls is shown in Figure 9 and Table 8.

\section{Figure 9}

Plurality distribution of cohort

\section{Plurality Distribution}

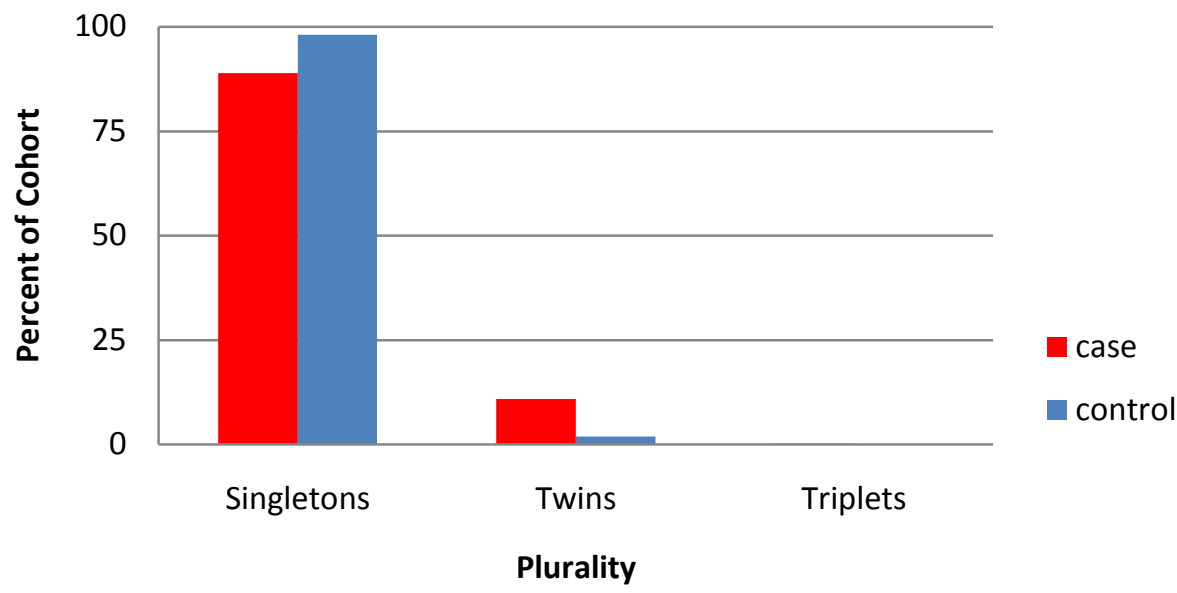

Table 8

Plurality distribution of cohort.

\begin{tabular}{|c|c|c|c|c|}
\hline & \multicolumn{2}{|c|}{ Cases } & \multicolumn{2}{c|}{ Controls } \\
\hline Plurality & Numbers & $\%$ & Numbers & $\%$ \\
\hline Singletons & 522 & 88.9 & 1131 & 1.9 \\
\hline Twins & 64 & 10.9 & 22 & 0.0 \\
\hline Triplets & 1 & 0.2 & 0 & 100 \\
\hline Total & 587 & 100 & 1153 & 0.1 \\
\hline
\end{tabular}




\section{Maternal age distribution}

Maternal age of cases and controls is shown in Figure 10 and Table 9. For cases the mean maternal age was 31.3 years $(30.9-31.795 \% \mathrm{Cl})$ and for controls 31.0 years $(30.7-31.395 \% \mathrm{Cl})$.

\section{Figure 10}

Maternal age distribution of cohort

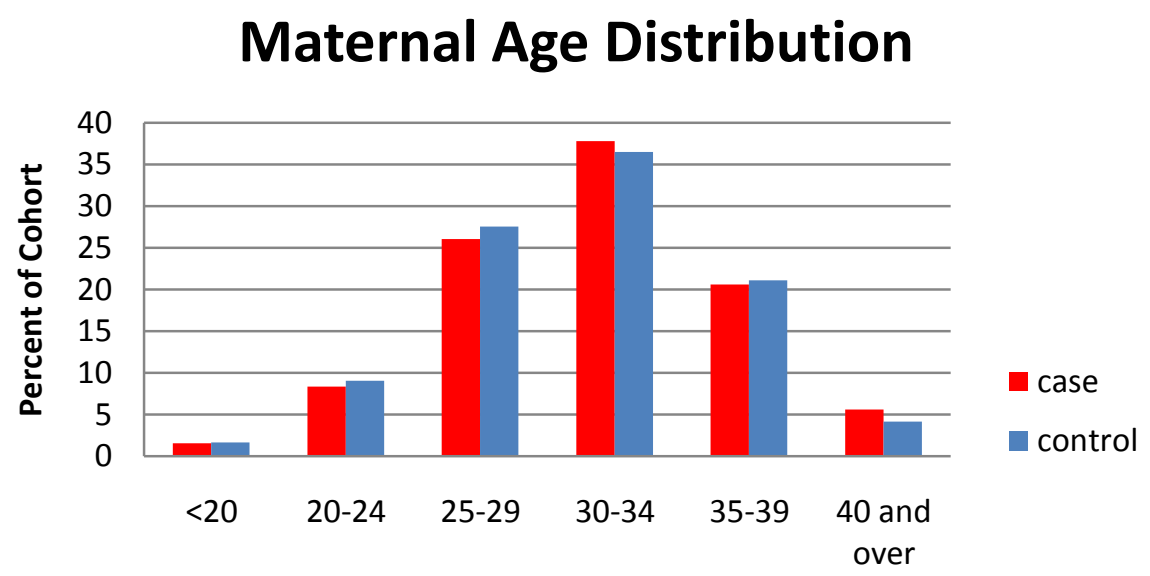

Maternal age (years)

\section{Table 9}

Maternal age distribution of cohort.

\begin{tabular}{|c|c|c|c|c|}
\hline & \multicolumn{2}{|c|}{ Cases } & \multicolumn{2}{c|}{ Controls } \\
\hline Maternal Age & Number & $\%$ & Number & $\%$ \\
\hline$<20$ & 9 & 1.5 & 19 & 1.7 \\
\hline $\mathbf{2 0 - 2 4}$ & 49 & 8.3 & 104 & 9.0 \\
\hline $\mathbf{2 5 - 2 9}$ & 153 & 26.1 & 317 & 27.5 \\
\hline $\mathbf{3 0 - 3 4}$ & 222 & 37.8 & 420 & 36.5 \\
\hline $\mathbf{3 5 - 3 9}$ & 121 & 20.6 & 243 & 21.1 \\
\hline $\mathbf{4 0}$ and over & 33 & 5.6 & 48 & 4.2 \\
\hline Total & $\mathbf{5 8 7}$ & $\mathbf{1 0 0}$ & $\mathbf{1 1 5 1}$ & $\mathbf{1 0 0}$ \\
\hline
\end{tabular}

\section{Type of delivery distribution}

Type of delivery for cases and controls is shown in Figure 11 and Table 10. 
Figure 11

Type of delivery distribution of cohort

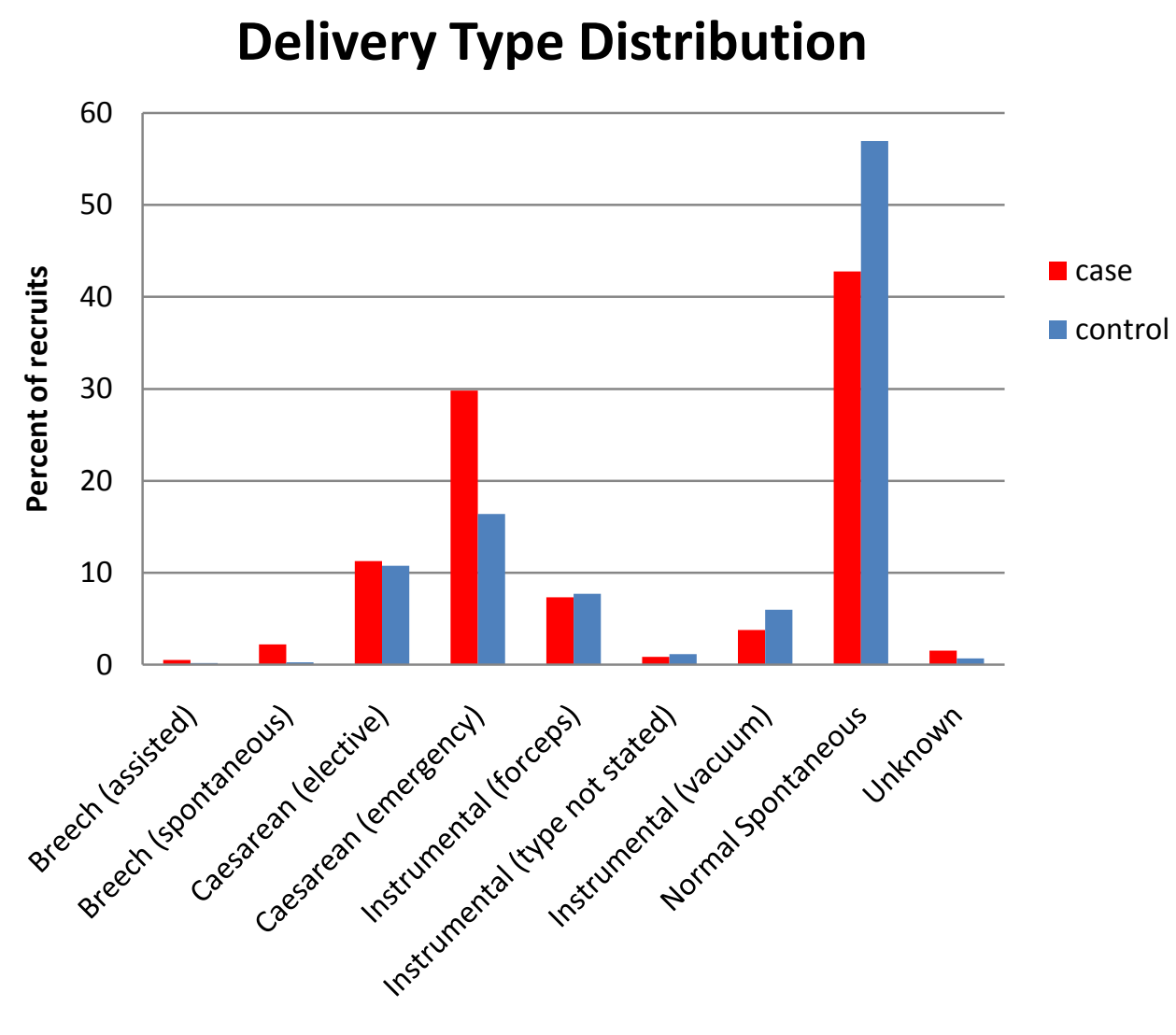

Delivery Type 


\section{Chapter 3 Cohort Demographics}

Table 10

Type of delivery distribution of cohort.

\begin{tabular}{|c|c|c|c|c|}
\hline & \multicolumn{2}{|c|}{ Cases } & \multicolumn{2}{c|}{ Controls } \\
\hline Delivery Type & Number & $\%$ & 2 & 0.2 \\
\hline Breech (assisted) & 3 & 0.5 & 3 & 0.3 \\
\hline Breech (spontaneous) & 13 & 2.2 & 124 & 10.7 \\
\hline Caesarean (elective) & 66 & 11.2 & 189 & 7.4 \\
\hline Caesarean (emergency) & 175 & 29.8 & 89 & 1.1 \\
\hline Instrumental (forceps) & 43 & 7.3 & 13 & 6.0 \\
\hline Instrumental (type not stated) & 5 & 0.9 & 69 & 56.9 \\
\hline Instrumental (vacuum) & 22 & 3.7 & 657 & 0.7 \\
\hline Normal Spontaneous & 251 & 42.8 & 1154 & 100 \\
\hline Unknown & 9 & 1.5 & & \\
\hline Total & 587 & 100 & & \\
\hline
\end{tabular}




\section{Birth weight centile distribution}

Birth weight centiles were calculated using GROW centile calculator (Gardosi J, Francis A. Customised Weight Centile Calculator - GROW-Centile v6.4 2009; Gestation Network; www.gestation.net; v6.4) for cases and controls. The distribution of birth weight centiles is shown in Figure 12 and Table 11. The mean centile birth weight for cases was 43 (40.2-45.8 95\% $\mathrm{Cl})$ and for controls $55(47.2-62.895 \% \mathrm{Cl})$.

\section{Figure 12}

Birth weight centile distribution of cohort

\section{Birth Weight Centile Distribution}

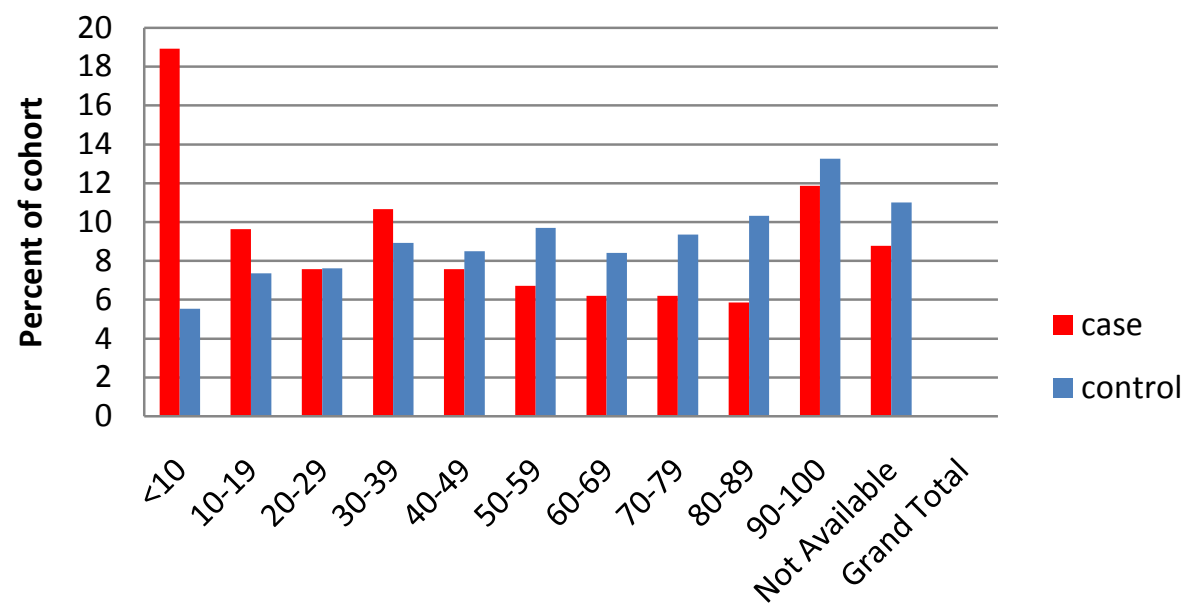

Birth weight centile 


\section{Chapter 3 Cohort Demographics}

Table 11

Birth weight centile distribution of cohort.

\begin{tabular}{|c|c|c|c|c|}
\hline \multirow[b]{2}{*}{ Centile } & \multicolumn{2}{|c|}{ Cases } & \multicolumn{2}{|c|}{ Controls } \\
\hline & Number & $\%$ & Number & $\%$ \\
\hline$<10$ & 110 & 18.9 & 64 & 5.55 \\
\hline $10-19$ & 56 & 9.64 & 85 & 7.37 \\
\hline $20-29$ & 44 & 7.57 & 88 & 7.63 \\
\hline $30-39$ & 62 & 10.7 & 103 & 8.93 \\
\hline $40-49$ & 44 & 7.57 & 98 & 8.49 \\
\hline $50-59$ & 39 & 6.71 & 112 & 9.71 \\
\hline $60-69$ & 36 & 6.2 & 97 & 8.41 \\
\hline $70-79$ & 36 & 6.2 & 108 & 9.36 \\
\hline $80-89$ & 34 & 5.85 & 119 & 10.3 \\
\hline $90-100$ & 69 & 11.9 & 153 & 13.3 \\
\hline Not Available & 51 & 8.78 & 127 & 11 \\
\hline Total & 581 & 100 & 1154 & 100 \\
\hline
\end{tabular}




\section{Chapter 3 Cohort Demographics}

\section{Assessment of control cohort bias}

To assess for potential biases in the control cohort, key demographic data were compared to population data available in Australia. Biases may have arisen during the recruitment process from selective response rates, compliance or incomplete data linking.

Perinatal statistics data in Australia was obtained from "Australia's Mothers and Babies $2007^{\prime 25}$. The reported mean of the population data is compared to the calculated mean for corresponding data in the control cohort. Population data was not available for birth weight centiles or Apgar scores at 1 minute. Unless otherwise stated, chi-squared test statistics are on one degree of freedom. 


\section{Gender}

Figure 13 and Table 12 compare gender proportions between the control cohort and Australian population data. Comparison of the gender distribution revealed that the recruited control cohort contained proportionally more females than the Australian population (chi square test, $\mathrm{p}<0.001)$. Caution must be used when making inferences about the wider population based upon this cohort as it does not statistically represent the population, even though this difference is unlikely to be of clinical importance.

\section{Figure 13}

Comparison of delivery type between control cohort and population data

\section{Gender Comparison}

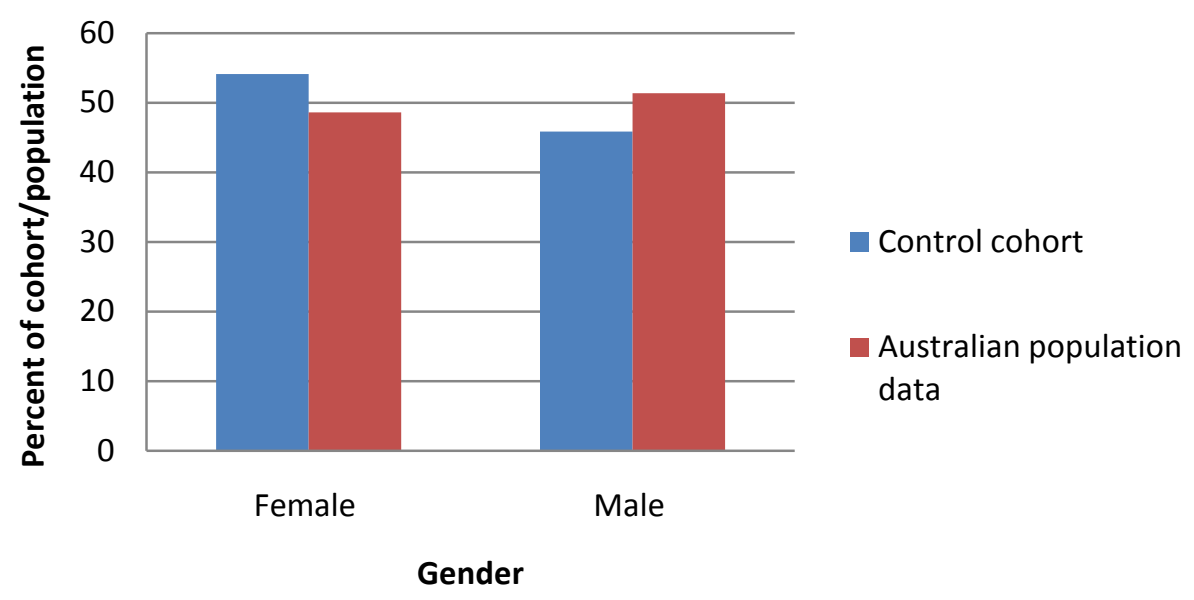




\section{Chapter 3 Cohort Demographics}

Table 12

Comparison of gender distribution between control cohort and population data.

\begin{tabular}{|c|c|c|c|c|}
\hline & \multicolumn{2}{|c|}{ Control } & Population & P value* \\
\hline Gender & Number & $\%$ & $\%$ & \\
\hline Female & 625 & 54.2 & 48.6 & $<0.001$ \\
\hline Male & 529 & 45.8 & 51.4 & $<0.001$ \\
\hline Total & 1154 & 100 & 100 & \\
\hline
\end{tabular}

* Chi square test 


\section{Chapter 3 Cohort Demographics}

\section{Gestational age}

Figure 14 and Table 13 compares gestational age between the control cohort and Australian population data. The mean gestational age in the control cohort was 39.3 (39.2-39.4 95\% Cl) weeks and population mean in Australia is 38.9 weeks. The gestational age distribution as seen in Figure 17 is very similar between our cohort and the population data (with distribution of early preterm, preterm and term statistically correlating as shown in Table 16) but since the 95\% confidence interval of the observed mean does not encompass the population mean, there is a statistical difference between the two. Caution must be used when making inferences about the wider population based upon this cohort as it does not statistically represent the population, even though this difference is unlikely to be of clinical importance. 


\section{Figure 14}

Comparison of gestational age between control cohort and population data

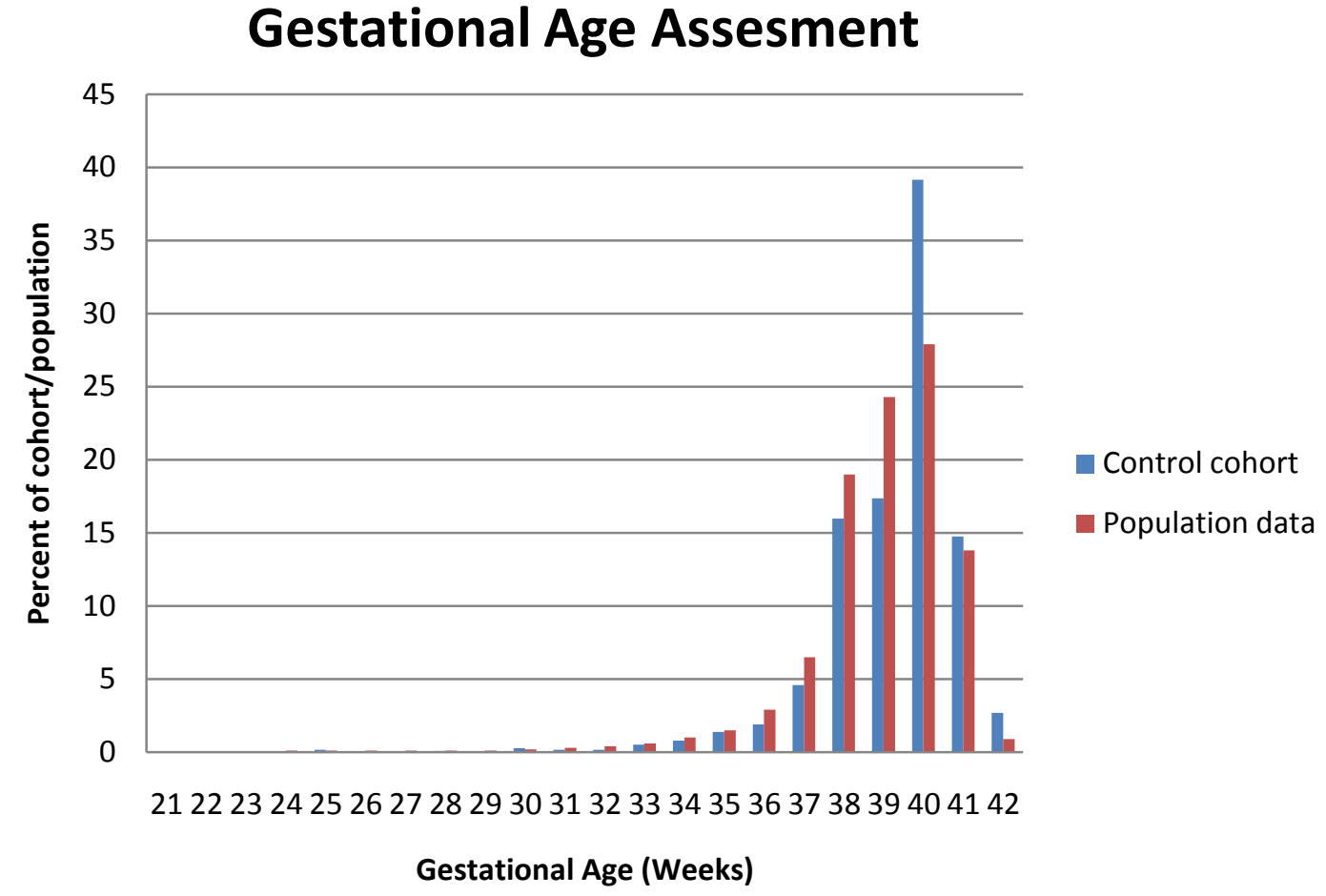

Table 13

Comparison of gestational age between control cohort and population data.

\begin{tabular}{|c|c|c|c|c|}
\hline & \multicolumn{2}{|c|}{ Control } & Population & P value* \\
\hline $\begin{array}{c}\text { Gestational } \\
\text { Age (weeks) }\end{array}$ & Number & $\%$ & $\%$ & \\
\hline$<32$ & 8 & 0.69 & 1.08 & 0.21 \\
\hline $\mathbf{3 2 - 3 6}$ & 55 & 4.77 & 4.33 & 0.461 \\
\hline $\mathbf{3 6 +}$ & 1089 & 94.53 & 94.59 & 0.927 \\
\hline Total & 1152 & 100 & 100 & \\
\hline
\end{tabular}

* Chi square test. 


\section{Birth weight}

Figure 15 and Table 14 compares birth weight between the control cohort and Australian population data. The mean birth weight in the control cohort was 3456.6g (3425.7-3488.5 95\% Cl) which approached the true population mean in Australia of 3374 grams. Since the $95 \%$ confidence intervals did not encompass the Australian population mean, caution must be exercised when extrapolating study results relating to the birth weight of babies to the Australian population.

\section{Figure 15}

Comparison of birth weight between control cohort and population data

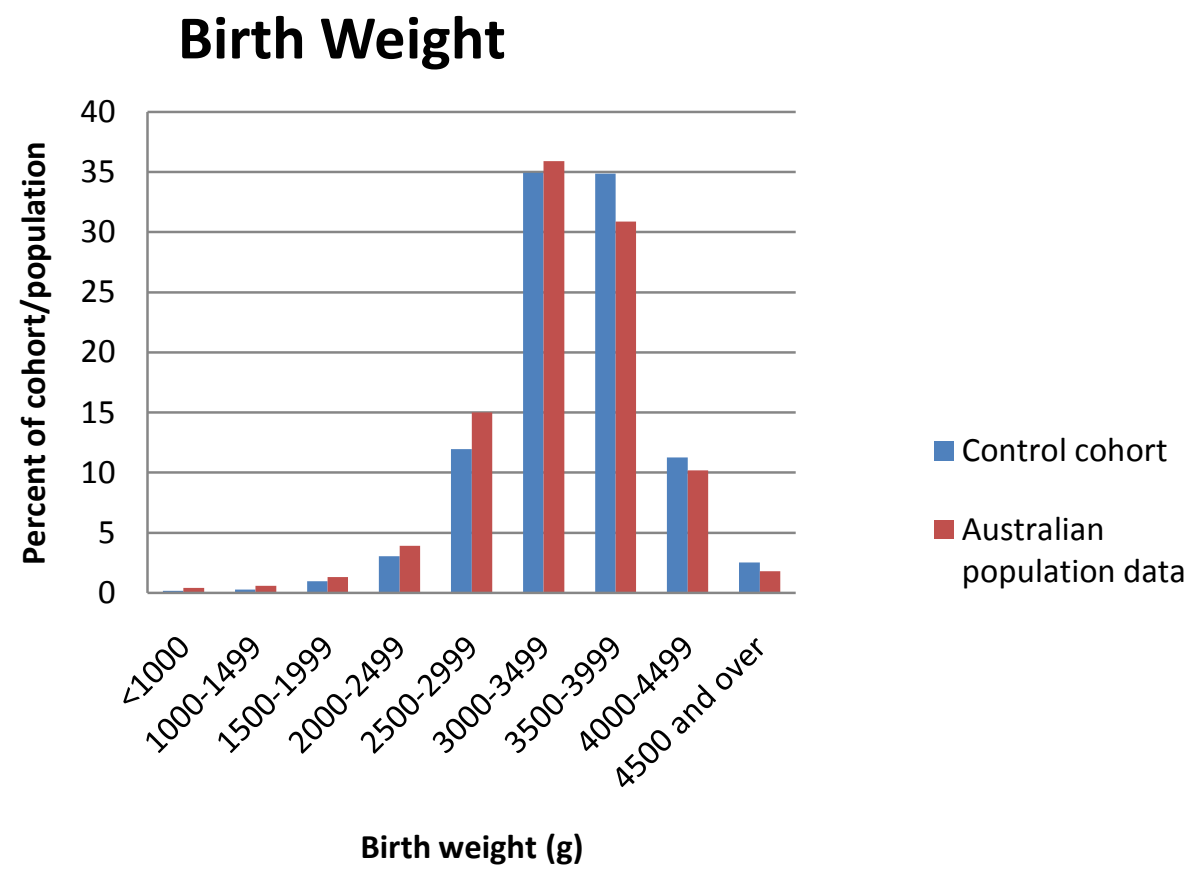




\section{Chapter 3 Cohort Demographics}

\section{Table 14}

Comparison of birth weight between control cohort and Australian population data.

\begin{tabular}{|c|c|c|c|c|}
\hline & \multicolumn{2}{|c|}{ Control cohort } & Population data & P value * \\
\hline Birth Weight & Number & $\%$ & $\%$ & \\
\hline$<1000$ & 2 & 0.2 & 0.4 & 0.171 \\
\hline $\mathbf{1 0 0 0 - 1 4 9 9}$ & 3 & 0.3 & 0.6 & 0.161 \\
\hline $\mathbf{1 5 0 0 - 1 9 9 9}$ & 11 & 1.0 & 1.3 & 0.359 \\
\hline $\mathbf{2 0 0 0 - 2 4 9 9}$ & 35 & 3.0 & 3.9 & 0.134 \\
\hline $\mathbf{2 5 0 0 - 2 9 9 9}$ & 138 & 12.0 & 15 & 0.004 \\
\hline $\mathbf{3 0 0 0 - 3 4 9 9}$ & 403 & 35.0 & 35.9 & 0.517 \\
\hline $\mathbf{3 5 0 0 - 3 9 9 9}$ & 402 & 34.9 & 30.9 & 0.004 \\
\hline $\mathbf{4 0 0 0 - 4 4 9 9}$ & 130 & 11.3 & 10.2 & 0.237 \\
\hline $\mathbf{4 5 0 0}$ and over & 29 & 2.5 & 1.8 & 0.053 \\
\hline Total & $\mathbf{1 1 5 3}$ & $\mathbf{1 0 0}$ & $\mathbf{1 0 0}$ & \\
\hline
\end{tabular}

* Chi square test 


\section{Apgar score}

Figure 16 and Table 15 compares Apgar scores ( 5 minutes) between the control cohort and Australian population data. The cohort had significantly less Apgar scores in the 7-10 range when compared to the population (chi squared test, $\mathrm{P}<0.001$ ) while the ranges $0-7$ were representative. This statistical significance needs to be considered when making inferences about the population based upon data using this cohort.

\section{Figure 16}

Comparison of Apgar scores ( 5 minutes) between control cohort and population data

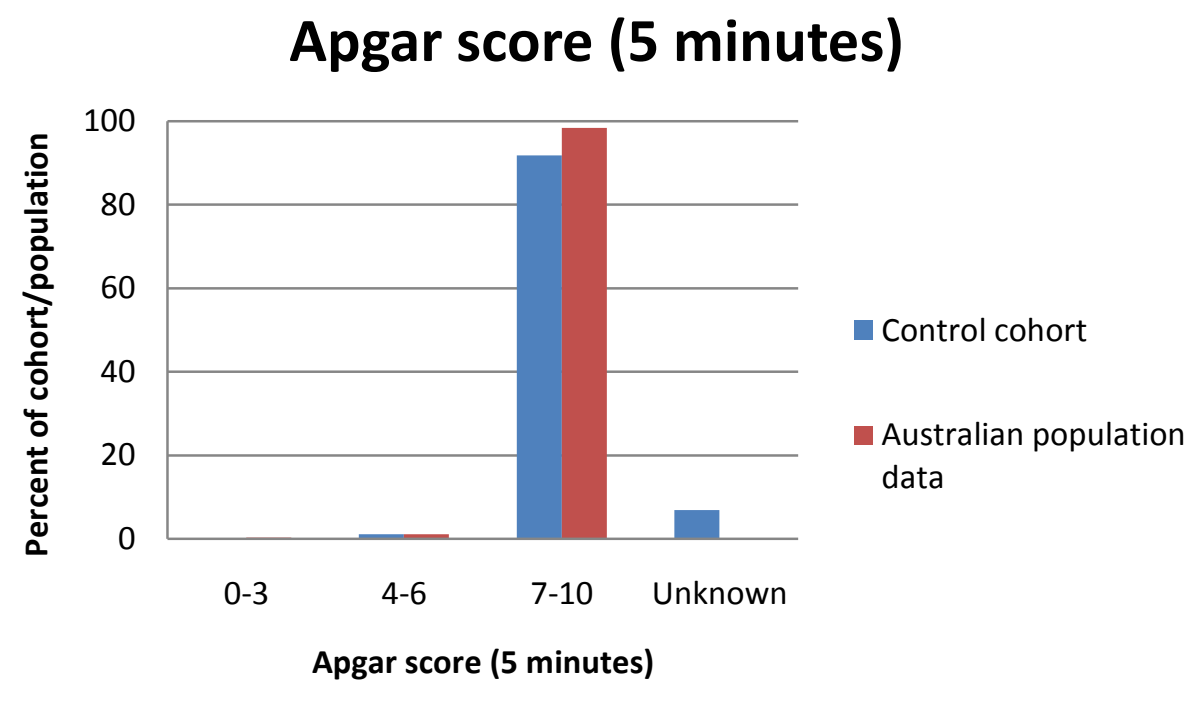




\section{Chapter 3 Cohort Demographics}

\section{Table 15}

Comparison of Apgar scores (5 minutes) between control cohort and Australian population data.

\begin{tabular}{|c|c|c|c|c|}
\hline & \multicolumn{2}{|c|}{ Control cohort } & Population data & P value* \\
\hline Apgar (5) & Number & $\%$ & $\%$ & \\
\hline $0-3$ & 2 & 0 & 0 & 0.39 \\
\hline $4-6$ & 13 & 1 & 1 & 0.88 \\
\hline $7-10$ & 1060 & 92 & 98 & $<0.001$ \\
\hline Unknown & 79 & 7 & 0 & $<0.001$ \\
\hline Total & 1154 & 100 & 100 & \\
\hline
\end{tabular}

* Chi squared test 


\section{Chapter 3 Cohort Demographics}

\section{Plurality}

Figure 17 and Table 16 compares plurality between the control cohort and Australian population data. The cohort is statistically representative of plurality for the Australian population.

\section{Figure 17}

Comparison of plurality between control cohort and population data

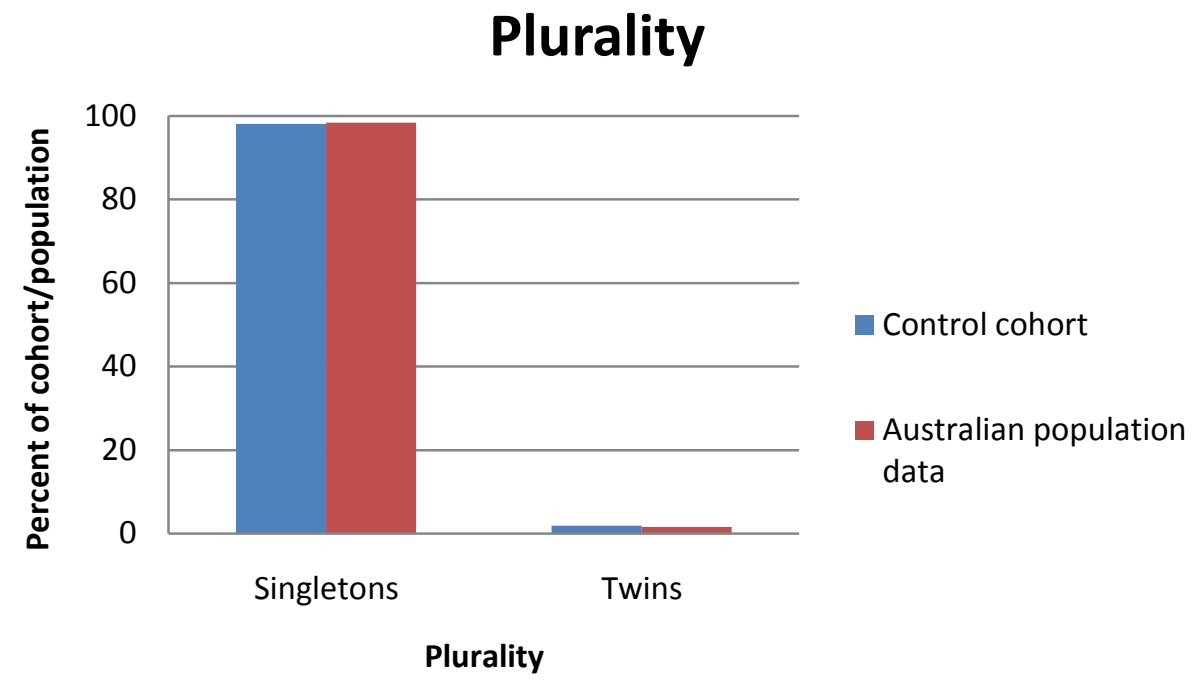

\section{Table 16}

Comparison of plurality between control cohort and Australian population data.

\begin{tabular}{|c|c|c|c|c|}
\hline & \multicolumn{2}{|c|}{ Control cohort } & Population data & P value* \\
\hline Plurality & Number & $\%$ & $\%$ & \\
\hline Singletons & 1131 & 98.1 & 98.4 & 0.407 \\
\hline Twins & 22 & 1.9 & 1.6 & 0.407 \\
\hline Total & 1153 & 100 & 100 & \\
\hline
\end{tabular}

* Chi squared test 


\section{Maternal age}

The mean maternal age in Australia for 2007 was 29.9 years compared to 31.0 years (30.7-31.3 95\% Cl) for the control cohort. Figure 18 and Table 17 compare the distribution of maternal ages between the control cohort and the population data. The maternal age distribution as seen in Figure 14 is very similar between our cohort and the population data but since the $95 \%$ confidence interval of the observed mean does not encompass the population mean, there is a statistical difference between the two. Caution must be used when making inferences about the wider population based upon this cohort as it does not statistically represent the population, even though this difference is unlikely to be of clinical importance.

\section{Figure 18}

Comparison of maternal age between control cohort and population data

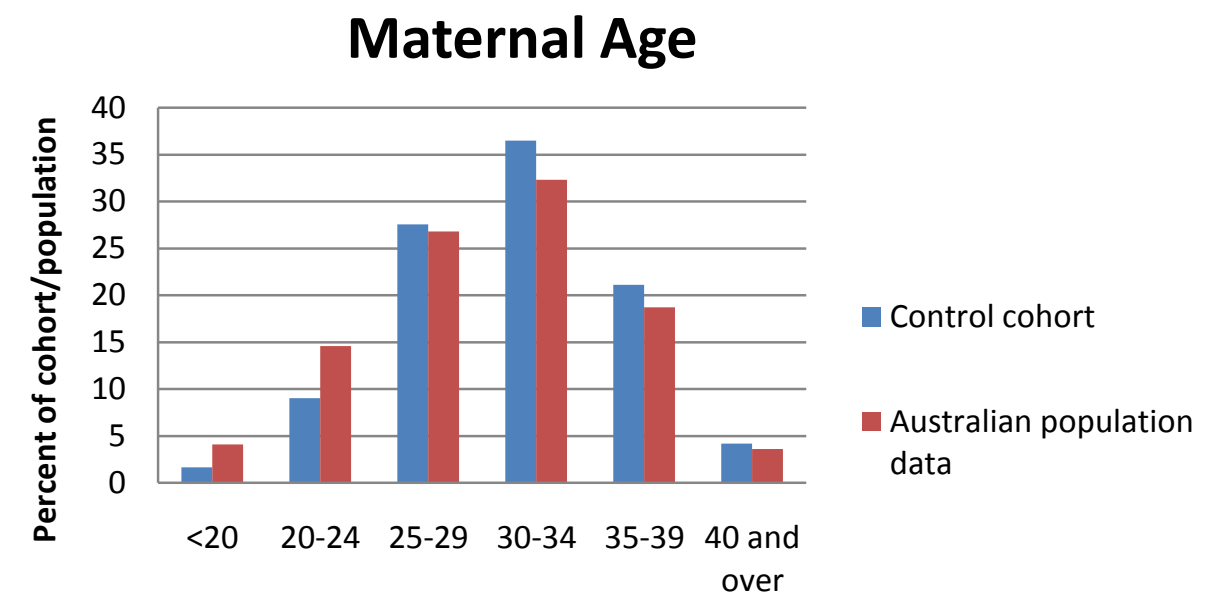

Maternal Age (years) 


\section{Chapter 3 Cohort Demographics}

Table 17

Comparison of maternal age between control cohort and population data.

\begin{tabular}{|c|c|c|c|c|}
\hline & \multicolumn{2}{|c|}{ Control Cohort } & Population Data & P value \\
\hline Maternal Age & Number & $\%$ & $\%$ & \\
\hline$<\mathbf{2 0}$ & 19 & 1.7 & 4.1 & $<0.001$ \\
\hline $\mathbf{2 0 - 2 4}$ & 104 & 9.0 & 14.6 & $<0.001$ \\
\hline $\mathbf{2 5 - 2 9}$ & 317 & 27.5 & 26.8 & 0.554 \\
\hline $\mathbf{3 0 - 3 4}$ & 420 & 36.5 & 32.3 & 0.002 \\
\hline $\mathbf{3 5 - 3 9}$ & 243 & 21.1 & 18.7 & 0.036 \\
\hline $\mathbf{4 0}$ and over & 48 & 4.2 & 3.6 & 0.261 \\
\hline Total & $\mathbf{1 1 5 1}$ & $\mathbf{1 0 0}$ & $\mathbf{1 0 0 . 1 *}$ & \\
\hline
\end{tabular}

* Data as reported in Laws et al $2009^{95}$.

† Chi square test 


\section{Type of delivery}

Figure 19 and Table 18 compare delivery type between the control cohort and Australian population data. Comparison of the proportions of delivery type between the control cohort and the Australian population data showed a high degree of correlation with the exception of Caesarean section and Instrumental delivery (forceps) (Chi square test both $\mathrm{p}<0.05$ ). Caution must be used when making inferences about the wider population based upon this cohort as it does not statistically represent the population, even though this small difference is unlikely to be of clinical importance.

\section{Figure 19}

Comparison of delivery type between control cohort and population data

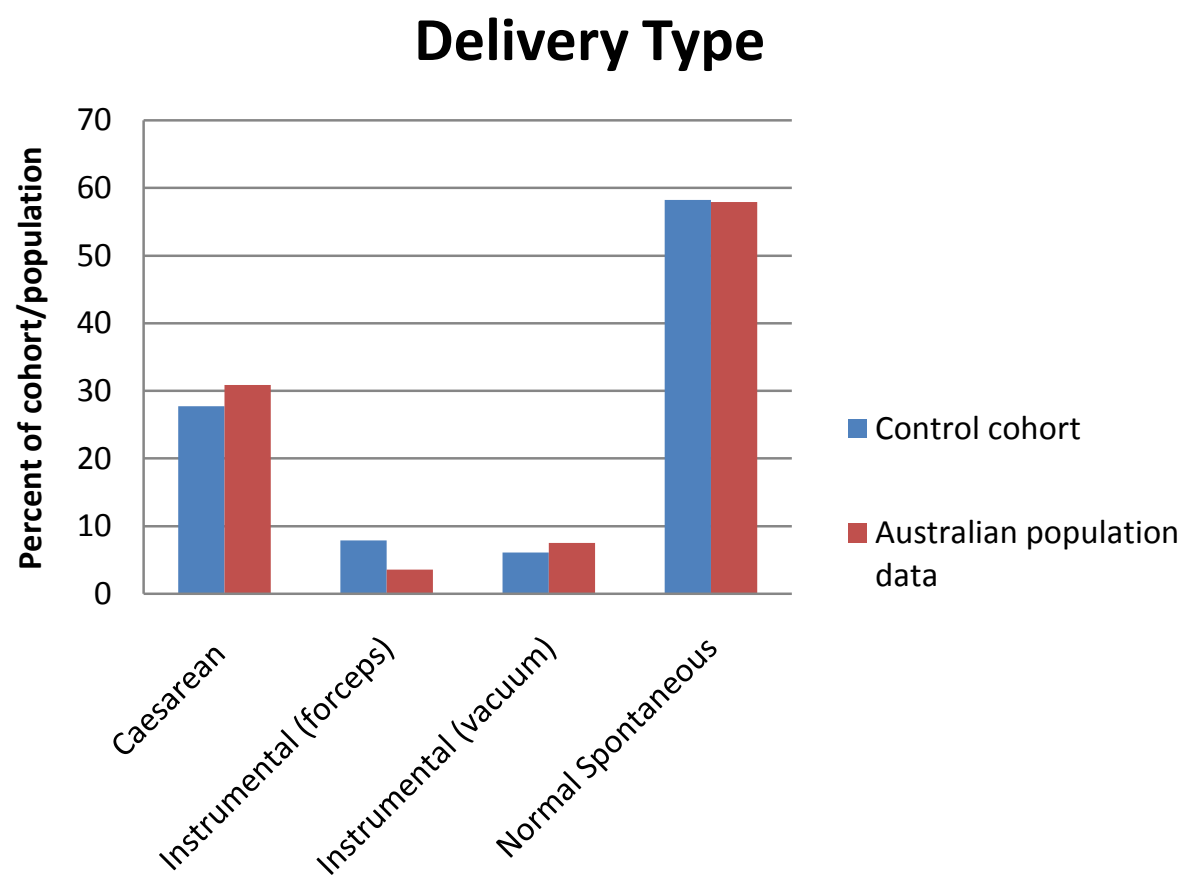




\section{Chapter 3 Cohort Demographics}

\section{Table 18}

Comparison of delivery type between control cohort and population data.

\begin{tabular}{|c|c|c|c|c|}
\hline & \multicolumn{2}{|c|}{ Control cohort } & Population data & Pvalue' $^{+}$ \\
\hline Delivery Type & Number & $\%$ & 30.9 & 0.023 \\
\hline Caesarean & 313 & 27.7 & 3.6 & $<0.001$ \\
\hline Instrumental (forceps) & 89 & 7.9 & 7.5 & 0.07 \\
\hline Instrumental (vacuum) & 69 & 6.1 & 57.9 & 0.833 \\
\hline Normal Spontaneous & 657 & 58.2 & $99.9 *$ & \\
\hline Total & 1128 & 100 & & \\
\hline
\end{tabular}

* Data as reported in Laws et al $2009^{95}$.

† Chi square test 


\section{Chapter 3 Cohort Demographics}

\section{Assessment of case cohort bias}

To assess for potential biases in the case cohort, key clinical features were compared to cerebral palsy population data available in Australia. Biases may have arisen during the recruitment process from selective response rates, compliance or incomplete data linking.

The Australian Cerebral Palsy Register Annual Report $2009{ }^{96}$ provided population data for cerebral palsy cases in Australia. Population data was considered to be the combined data from the Western Australian, South Australian and Victorian Registers as these are well established and have mandatory reporting of cerebral palsy diagnosis. Mean reported cerebral palsy population data was compared to the calculated mean for corresponding data in the case cohort. Cerebral palsy population data was not available for Apgar scores, type of delivery or birth weight centiles. 


\section{Gender}

Figure 20 and Table 19 compares gender between the case cohort and cerebral palsy population data. A Chi square test did not show any statistical differences in the gender distribution between the case cohort and the cerebral palsy population data.

\section{Figure 20}

Comparison of gender distribution between case cohort and cerebral palsy population data

\section{Cerebral Palsy Gender}

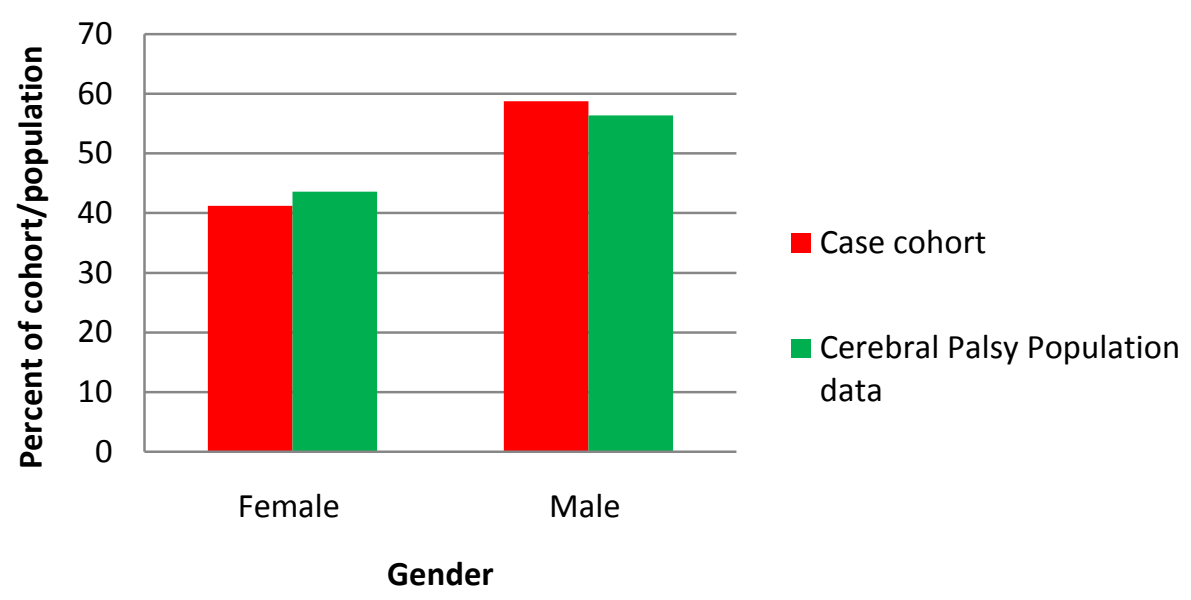

\section{Table 19}

Comparison of gender distribution between case cohort and cerebral palsy population data

\begin{tabular}{|c|c|c|c|c|}
\hline & \multicolumn{2}{|c|}{ Case cohort } & Cerebral Palsy Population data & P value* \\
\hline Gender & Number & $\%$ & $\%$ & 0.325 \\
\hline Female & 242 & 41.2 & 43.6 & 0.325 \\
\hline Male & 345 & 58.8 & 56.4 & \\
\hline Total & $\mathbf{5 8 7}$ & $\mathbf{1 0 0}$ & $\mathbf{1 0 0}$ & \\
\hline
\end{tabular}

* Chi square test

\section{Gestational age}

Figure 21 and Table 20 compares gestational age between the case cohort and cerebral palsy population data. The population gestational age mean for children born with cerebral palsy 
is 35.3 weeks, the same as our observed mean of 35.3 weeks $(34.9-35.795 \% \mathrm{Cl})$. A comparison of the distributions between the recruited cohort and the cerebral palsy population data showed a significant difference in the $28-31$ weeks age group (Chi squared test, $p<0.05$ ) suggesting caution is required when extrapolating results in this subgroup to the wider population.

\section{Figure 21}

Comparison of gestational age between case cohort and cerebral palsy population data

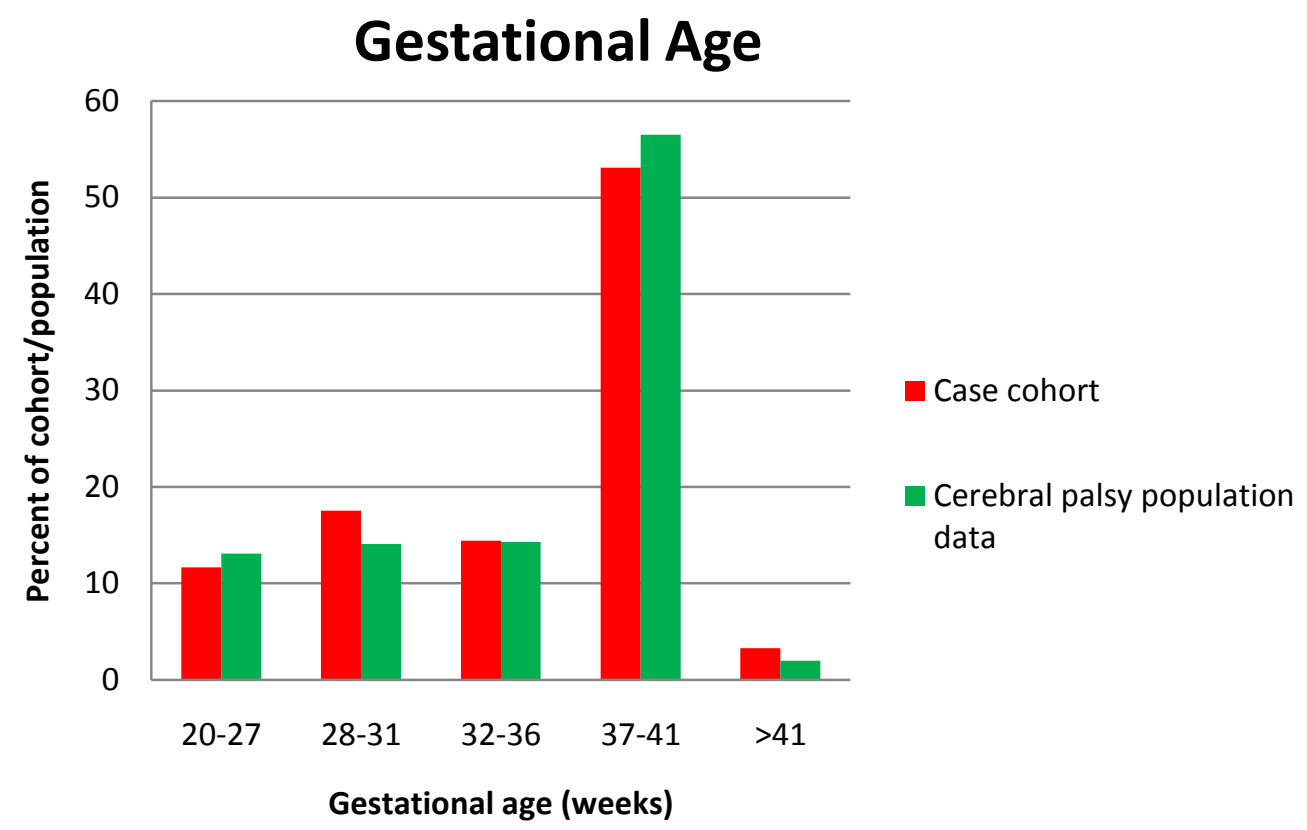




\section{Chapter 3 Cohort Demographics}

\section{Table 20}

Comparison of gestational age between case cohort and cerebral palsy population data.

\begin{tabular}{|c|c|c|c|c|}
\hline & \multicolumn{2}{|c|}{ Case cohort } & Cerebral palsy population data & P value* \\
\hline $\begin{array}{c}\text { Gestational } \\
\text { age (weeks) }\end{array}$ & Number & $\%$ & $\%$ & 0.38 \\
\hline $\mathbf{2 0 - 2 7}$ & 68 & 11.7 & 13.1 & 0.042 \\
\hline $\mathbf{2 8 - 3 1}$ & 102 & 17.5 & 14.1 & 0.953 \\
\hline $\mathbf{3 2 - 3 6}$ & 84 & 14.4 & 14.3 & 0.145 \\
\hline $\mathbf{3 7 - 4 1}$ & 309 & 53.1 & 56.5 & 0.068 \\
\hline$>41$ & 19 & 3.3 & 2 & 100 \\
\hline Total & $\mathbf{5 8 2}$ & $\mathbf{1 0 0}$ & $\mathbf{1 0 0}$ & \\
\hline
\end{tabular}

* Chi square test 


\section{Birth weight}

Figure 22 and Table 21 compares birth weight between the case cohort and cerebral palsy population data. The mean birth weight for children born with cerebral palsy is $2523 \mathrm{~g}$ compared with the study mean of $2535.8 \mathrm{~g}(2447.9-2623.795 \% \mathrm{Cl})$. The $95 \%$ confidence interval of the observed study mean encompasses the population mean.

\section{Figure 22}

Comparison of birth weights between case cohort and cerebral palsy population data.

\section{Birth Weight}

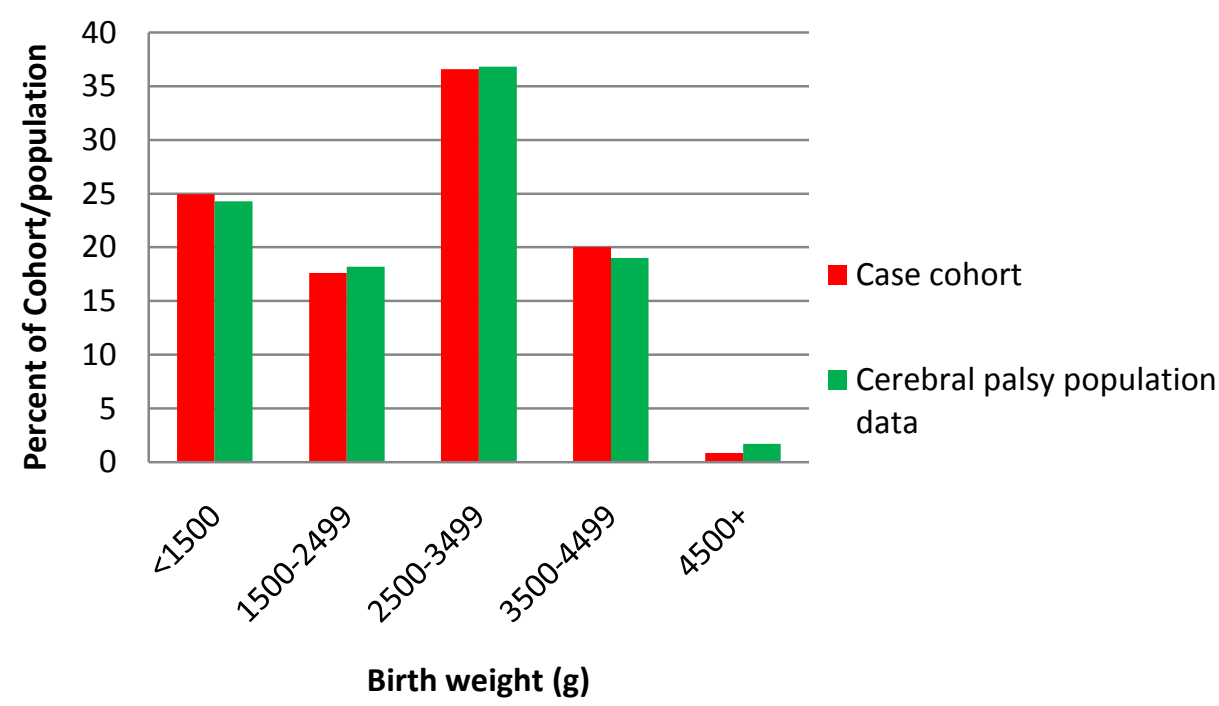




\section{Chapter 3 Cohort Demographics}

\section{Table 21}

Comparison of birth weight between case cohort and cerebral palsy population data.

\begin{tabular}{|c|c|c|c|c|}
\hline & \multicolumn{2}{|c|}{ Case cohort } & Cerebral palsy population data & P value* \\
\hline Birth Weight & Numbers & $\%$ & $\%$ & 0.744 \\
\hline$<\mathbf{1 5 0 0}$ & 146 & 25.0 & 24.3 & 0.756 \\
\hline $\mathbf{1 5 0 0 - 2 4 9 9}$ & 103 & 17.6 & 18.2 & 0.916 \\
\hline $\mathbf{2 5 0 0 - 3 4 9 9}$ & 214 & 36.6 & 36.8 & 0.59 \\
\hline $\mathbf{3 5 0 0 - 4 4 9 9}$ & 117 & 20.0 & 19 & 0.136 \\
\hline $\mathbf{4 5 0 0 +}$ & 5 & 0.9 & 1.7 & 100 \\
\hline Total & $\mathbf{5 8 5}$ & $\mathbf{1 0 0}$ & $\mathbf{1 0 0}$ & \\
\hline
\end{tabular}

* Chi square test 


\section{Chapter 3 Cohort Demographics}

\section{Plurality}

Figure 23 and Table 22 compare plurality between the case cohort and cerebral palsy population data. The plurality of the case cohort matched the cerebral palsy population profile.

Figure 23

Comparison of plurality between case cohort and cerebral palsy population data.

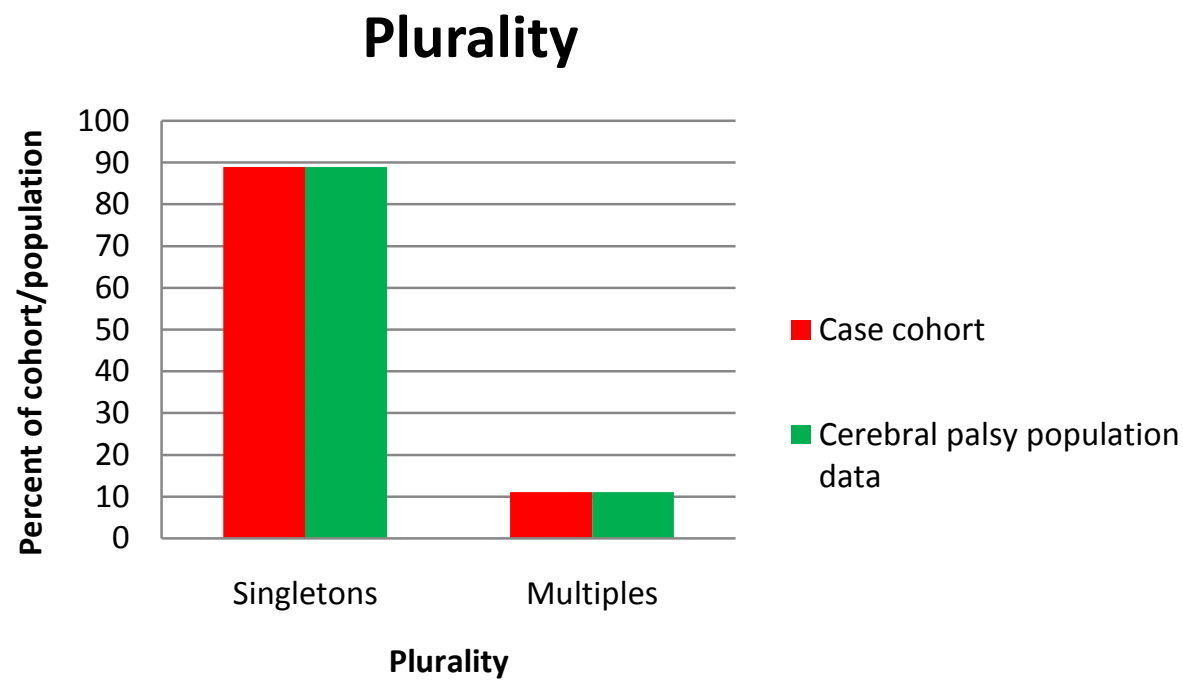

Table 22

Comparison of plurality between case cohort and population data.

\begin{tabular}{|c|c|c|c|}
\hline & \multicolumn{2}{|c|}{ Case cohort } & Cerebral palsy population data \\
\hline Plurality & Numbers & $\%$ & $\%$ \\
\hline Singletons & 522 & 88.9 & 88.9 \\
\hline Multiples & 65 & 11.1 & 11.1 \\
\hline Total & 587 & 100 & 100 \\
\hline
\end{tabular}




\section{Chapter 3 Cohort Demographics}

\section{Maternal age}

Figure 24 and Table 23 compares maternal age between the case cohort and the cerebral palsy population data. The population mean maternal age at the time of giving birth to a child with cerebral palsy is 29.4 years compared to our observed mean of $31.3(30.9-31.795 \% \mathrm{Cl})$. The maternal age distribution as seen in Figure 20 is very similar between our cohort and the population data but since the $95 \%$ confidence interval of the observed mean does not include the population mean, there is a statistical difference between the two. Caution must be used when making inferences about the wider population based upon this cohort as it does not statistically represent the population, even though this difference is unlikely to be of clinical importance.

\section{Figure 24}

Comparison of maternal age distribution between case cohort and cerebral palsy population data

\section{Maternal Age}

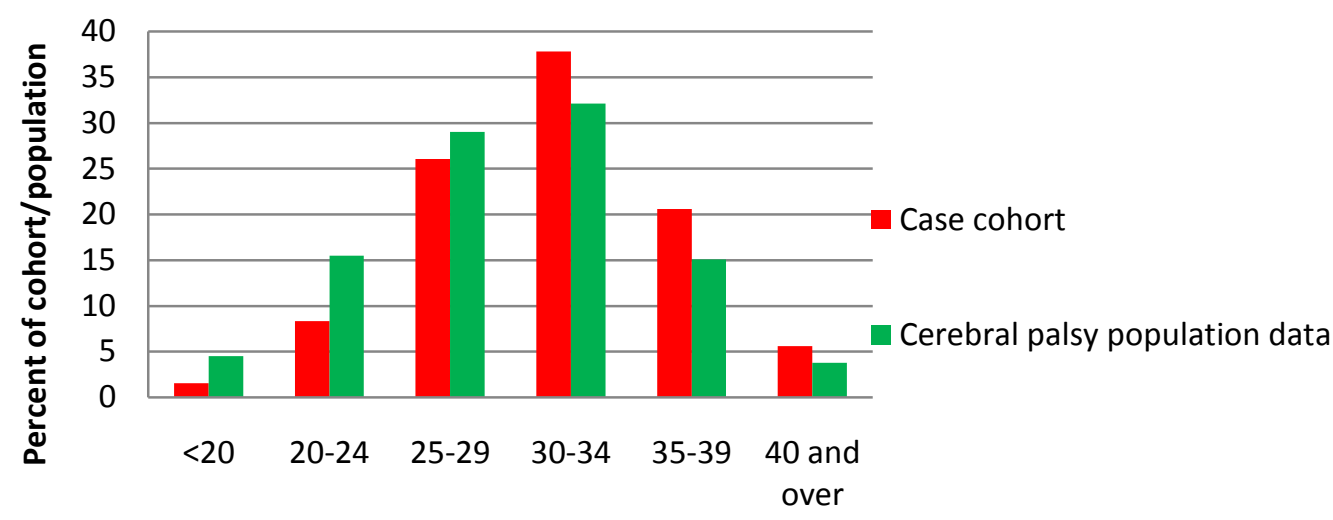

Maternal age (years) 


\section{Chapter 3 Cohort Demographics}

\section{Table 23}

Comparison of maternal age distribution between case cohort and cerebral palsy population data.

\begin{tabular}{|c|c|c|c|c|}
\hline & \multicolumn{2}{|c|}{ Case cohort } & Cerebral Palsy Population data & P value* \\
\hline $\begin{array}{c}\text { Maternal age } \\
\text { (years) }\end{array}$ & Number & $\%$ & $\%$ & 0.001 \\
\hline$<\mathbf{2 0}$ & 9 & 1.5 & 4.5 & $<0.001$ \\
\hline $\mathbf{2 0 - 2 4}$ & 49 & 8.3 & 15.5 & 0.535 \\
\hline $\mathbf{2 5 - 2 9}$ & 153 & 26.1 & 29 & $<0.001$ \\
\hline $\mathbf{3 0 - 3 4}$ & 222 & 37.8 & 32.1 & $<0.001$ \\
\hline $\mathbf{3 5 - 3 9}$ & 121 & 20.6 & 15.1 & 0.021 \\
\hline $\mathbf{4 0}$ and over & 33 & 5.6 & 3.8 & 100 \\
\hline Total & $\mathbf{5 8 7}$ & $\mathbf{1 0 0}$ & & \\
\hline
\end{tabular}

* Chi square test 


\section{Cerebral palsy subtype}

Figure 25 and Table 24 compares cerebral palsy subtype between the case cohort and cerebral palsy population data. Comparing the proportion of cerebral palsy subtypes between the recruited cohort and cerebral palsy population data showed a significant difference for Diplegias (Chi square test, $p<0.05$ ). Caution must be used when making inferences about the wider population based upon this cohort as it does not statistically represent the population. It is possible that this difference has been uncovered by specifying the cerebral palsy subtype as 'other' or 'unknown' in the recruited cohort.

\section{Figure 25}

Comparison of cerebral palsy subtype between case cohort and cerebral palsy population data.

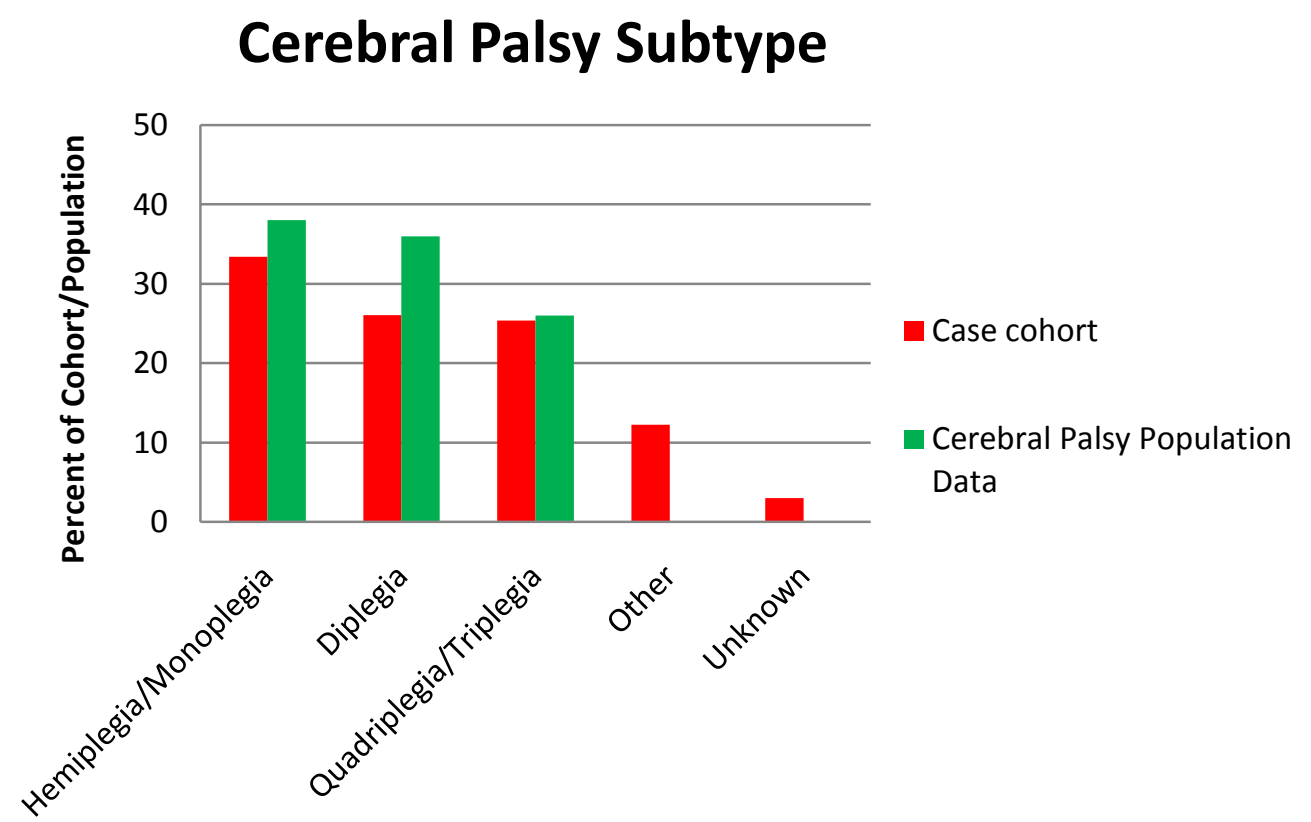

Cerebral Palsy Subtype 


\section{Chapter 3 Cohort Demographics}

\section{Table 24}

Comparison of cerebral palsy subtype between case cohort and cerebral palsy population data.

\begin{tabular}{|c|c|c|c|c|}
\hline & \multicolumn{2}{|c|}{ Case cohort } & Cerebral Palsy Population & P value* \\
\hline Cerebral Palsy Subtype & Number & $\%$ & $\%$ & 0.617 \\
\hline Hemiplegia/Monoplegia & 191 & 33.4 & 38 & 0.035 \\
\hline Diplegia & 149 & 26.0 & 26 & 0.097 \\
\hline Quadriplegia/Triplegia & 145 & 25.3 & N/A \\
\hline Other & 70 & 12.2 & - & N/A \\
\hline Unknown & 17 & 3.0 & 100 & \\
\hline Total & 572 & 100 & & \\
\hline
\end{tabular}

${ }^{*}$ Chi Square test 


\section{GMFCS (gross motor function classification system) level}

Figure 26 and Table 25 compare the diagnosed GMFCS level between the case cohort and cerebral palsy population data. GMFCS level proportions were equivalent to population proportions with the exception of Level 2 (Chi squared test, $\mathrm{p}<0.05$ ). Caution must be used when making inferences about the wider population based upon this cohort as it does not statistically represent the population. It is possible that this difference has arisen because $15 \%$ of the recruited cohort had yet to be assessed for GMFCS level.

\section{Figure 26}

Comparison of cerebral palsy GMFCS level between case cohort and cerebral palsy population data

\section{GMFCS}

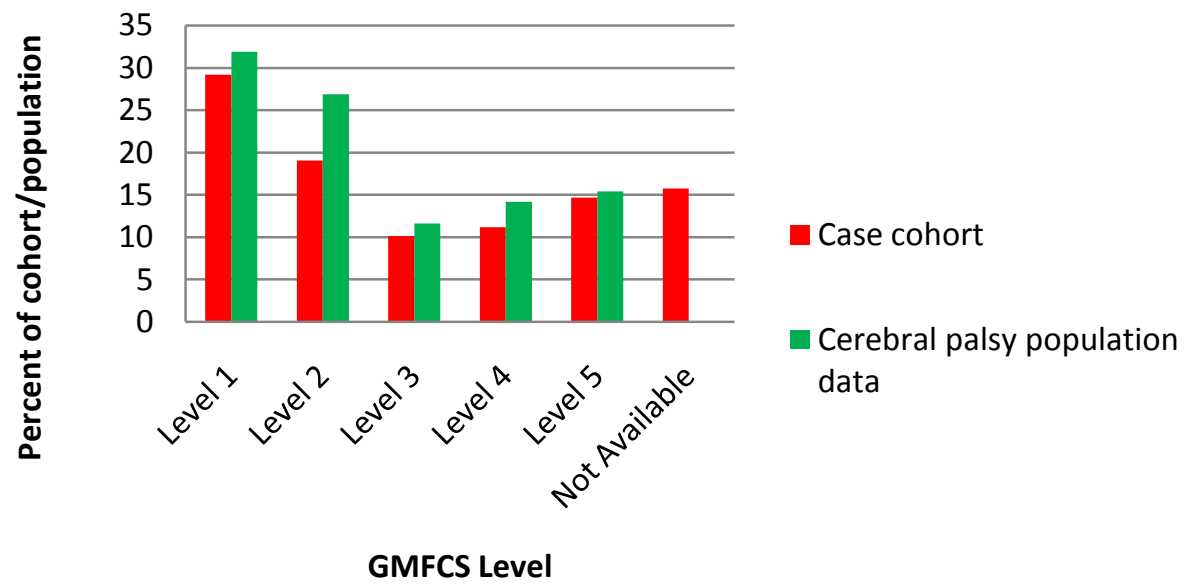




\section{Chapter 3 Cohort Demographics}

\section{Table 25}

Comparison of cerebral palsy GMFCS level between case cohort and population data.

\begin{tabular}{|c|c|c|c|c|}
\hline & \multicolumn{2}{|c|}{ Case cohort } & \multirow{2}{*}{$\begin{array}{c}\text { Cerebral palsy population data } \\
\%\end{array}$} & \multirow[t]{2}{*}{ P value* } \\
\hline GMFCS level & Number & $\%$ & & \\
\hline Level 1 & 167 & 29.2 & 31.9 & 0.266 \\
\hline Level 2 & 109 & 19.1 & 26.9 & 0.001 \\
\hline Level 3 & 58 & 10.1 & 11.6 & 0.418 \\
\hline Level 4 & 64 & 11.2 & 14.2 & 0.099 \\
\hline Level 5 & 84 & 14.7 & 15.4 & 0.736 \\
\hline Not Available & 90 & 15.7 & 0 & N/A \\
\hline Total & 572 & 100 & 100 & \\
\hline
\end{tabular}

${ }^{*}$ Chi Square test 


\section{Quality control of genotype data}

\section{Mendelian errors}

Genotyping data was assessed for Mendelian errors in mother child pairs. Calls inconsistent with the expected Mendelian inheritance patterns were marked as fails in both mother and child samples. Table 26 lists the Mendelian error rate for each SNP genotyped. All SNPs (Amelogenin, the gender control marker excluded) had an error rate of less that $1 \%$ for Mendelian consistency and were maintained for analysis. 


\section{Chapter 3 Cohort Demographics}

Table 26

Mendel error rate for SNP genotype data.

\begin{tabular}{|c|c|c|c|}
\hline SNP & $\%$ Mendel Fail Rate & SNP & $\%$ Mendel Fail Rate \\
\hline rs1042714 & 0.55 & rs1800871 & 0.23 \\
\hline rs1048971 & 0.05 & rs1801131 & 0.37 \\
\hline rs1061170 & 0.92 & rs1801133 & 0.37 \\
\hline rs11003125 & 0.14 & rs2243250 & 0.18 \\
\hline rs1137933 & 0.14 & rs243865 & 0.14 \\
\hline rs16135 & 0.05 & rs361525 & 0.09 \\
\hline rs16476 & 0.41 & rs3813946 & 0.18 \\
\hline rs16944 & 0.23 & rs4073 & 0.78 \\
\hline rs1715 & 0.00 & rs429358 & 0.51 \\
\hline rs17516265 & 0.00 & rs4961 & 0.23 \\
\hline rs1799963 & 0.00 & rs4986790 & 0.14 \\
\hline rs1800450 & 0.41 & rs5030737 & 0.05 \\
\hline rs1800451 & 0.00 & rs602128 & 0.28 \\
\hline rs1800469 & 0.55 & rs6025 & 0.00 \\
\hline rs1800576 & 0.09 & rs6098 & 0.14 \\
\hline rs1800610 & 0.46 & rs6103 & 0.28 \\
\hline rs1800629 & 0.00 & rs7095891 & 0.18 \\
\hline rs1800779 & 0.41 & rs7096206 & 0.28 \\
\hline rs1800795 & 0.18 & rs7412 & 0.37 \\
\hline
\end{tabular}




\section{Chapter 3 Cohort Demographics}

\section{Individual sample fails}

Genotype data from siblings was excluded from analysis to prevent disproportional sampling of these families genetics ( 8 families, $0.42 \%$ ). Where samples from more than one family were received, the first sample received was used in the analysis. Samples with an Amelogenin call inconsistent with data provided in the questionnaire (gender) were excluded from analysis ( 12 families, $0.62 \%$ ). Individual samples where $25 \%$ or more of the SNP genotyping had failed (including Mendel fails) was excluded from the analysis (23, $0.5 \%)$ as described by McMichael et al $2009^{90}$. These exclusions are summarised in Table 27 and accounted for $1.54 \%$ of the cohort.

\section{Table 27}

Summary of sample exclusions due to genotyping errors.

\begin{tabular}{|c|c|}
\hline Reason for failure & \% Failure rate (number) \\
\hline Siblings & $0.42(8)$ \\
\hline Inconsistent with questionnaire & $0.62(12)$ \\
\hline more than 25\% SNP failure & $0.5(23)$ \\
\hline
\end{tabular}




\section{Chapter 3 Cohort Demographics}

\section{SNP assay fails}

The genotyping failure rate was also determined for each SNP assessed. Table 28 lists each SNP in order of descending failure rate. The highest failure rate was found in rs6098 at 6.7\%. This level of failure is normal for this methodology and all SNPs were maintained for analysis.

Table 28

Summary of genotyping failure rates by SNP.

\begin{tabular}{|c|c|c|c|c|c|}
\hline Chromosome & SNP & Physical position & Number of fails & Number Genotyped & Frequency of fails \\
\hline 18 & rs6098 & 61564394 & 246 & 3634 & 0.07 \\
\hline 1 & rs1061170 & 196659237 & 200 & 3634 & 0.06 \\
\hline 19 & rs429358 & 45411941 & 160 & 3634 & 0.04 \\
\hline 19 & rs7412 & 45412079 & 138 & 3634 & 0.04 \\
\hline 2 & rs16944 & 113594867 & 122 & 3634 & 0.03 \\
\hline 19 & rs1800469 & 41860296 & 122 & 3634 & 0.03 \\
\hline 4 & rs4073 & 74606024 & 118 & 3634 & 0.03 \\
\hline 10 & rs1800450 & 54531235 & 115 & 3634 & 0.03 \\
\hline 10 & rs11003125 & 545320014 & 111 & 3634 & 0.03 \\
\hline 11 & rs602128 & 102713465 & 87 & 3634 & 0.02 \\
\hline 10 & rs7095891 & 545314461 & 78 & 3634 & 0.02 \\
\hline 7 & rs16476 & 24330219 & 75 & 3634 & 0.02 \\
\hline 19 & rs17516265 & 41860045 & 66 & 3634 & 0.02 \\
\hline 1 & rs1801133 & 894 & 64 & 3634 & 0.02 \\
\hline 18 & rs6103 & 61570503 & 64 & 3634 & 0.02 \\
\hline 5 & rs1042714 & 148206473 & 61 & 3634 & 0.02 \\
\hline 1 & rs1800871 & 206946634 & 55 & 3634 & 0.02 \\
\hline 5 & rs2243250 & 132009154 & 55 & 3634 & 0.02 \\
\hline 7 & rs1800795 & 22766645 & 55 & 3634 & 0.02 \\
\hline 1 & rs1048971 & 207646322 & 53 & 3634 & 0.01 \\
\hline 10 & rs7096206 & 54531461 & 53 & 3634 & 0.01 \\
\hline 1 & rs1801131 & 1515 & 52 & 3634 & 0.01 \\
\hline 4 & rs4961 & 2906707 & 52 & 3634 & 0.01 \\
\hline
\end{tabular}




\section{Chapter 3 Cohort Demographics}

\begin{tabular}{|c|c|c|c|c|c|}
\hline Chromosome & SNP & Physical position & Number of fails & Number Genotyped & Frequency of fails \\
\hline 7 & rs1800779 & 150689943 & 52 & 3634 & 0.01 \\
\hline 16 & rs243865 & 55511806 & 52 & 3634 & 0.01 \\
\hline 10 & rs1800451 & 54531226 & 49 & 3634 & 0.01 \\
\hline 6 & rs1800629 & 31525175 & 46 & 3634 & 0.01 \\
\hline 1 & rs3813946 & 207627693 & 42 & 3634 & 0.01 \\
\hline 20 & rs1800576 & 23030015 & 42 & 3634 & 0.01 \\
\hline 17 & rs1137933 & 26105932 & 37 & 3634 & 0.01 \\
\hline 6 & rs1800610 & 31525971 & 34 & 3634 & 0.01 \\
\hline 7 & rs16135 & 24327920 & 34 & 3634 & 0.01 \\
\hline 9 & rs4986790 & 120475302 & 33 & 3634 & 0.01 \\
\hline 10 & rs5030737 & 54531242 & 33 & 3634 & 0.01 \\
\hline 6 & rs361525 & 31525245 & 32 & 3634 & 0.01 \\
\hline 19 & rs1715 & 57186590 & 22 & 3634 & 0.01 \\
\hline 1 & rs6025 & 169519049 & 16 & 3634 & 0.00 \\
\hline 11 & rs1799963 & 46761055 & 10 & 3634 & 0.00 \\
\hline
\end{tabular}




\section{Chapter 3 Cohort Demographics}

\section{Hardy Weinberg equilibrium}

Hardy Weinberg equilibrium was assessed across all SNPs for the control cohort (mothers and children). Table 29 lists the $p$ value for each SNP comparing the observed allele frequency to the expected frequency as described by Wigginton et al ${ }^{97}$. SNP rs1061170 did not match the expected frequency $(\mathrm{p}<0.05)$. The cluster plot of genotype calls generated by the Sequenom MassArray genotyper confirmed that the genotype call rates for this SNP were inaccurate and this SNP was not analysed (see Figure 27 and compare to Figure 28 where accurate genotype calls have been made). SNP rs1715 and rs17516265 were non-polymorphic and therefore excluded. Thus 35 of the original 39 SNPs in the protocol were suitable for analyses.

\section{Table 29}

Summary of Hardy Weinberg equilibrium tests by SNP listed in ascending order of $p$ value.

\begin{tabular}{|c|c|c|c|c|c|c|c|}
\hline Chromosome & SNP & Allele 1 & Allele 2 & $\begin{array}{c}\text { Genotype } \\
\text { scores }\end{array}$ & $\begin{array}{l}\text { Observed } \\
\text { Heterozygous } \\
\text { frequency }\end{array}$ & $\begin{array}{l}\text { Expected } \\
\text { Hererozygous } \\
\text { Frequency }\end{array}$ & $P$ value \\
\hline 1 & rs1061170 & C & $\mathrm{T}$ & $273 / 753 / 687$ & 0.4396 & 0.4708 & $0.007^{*}$ \\
\hline 5 & rs1042714 & G & C & $360 / 831 / 577$ & 0.47 & 0.4925 & 0.06 \\
\hline 16 & rs243865 & $\mathrm{T}$ & C & $116 / 622 / 1041$ & 0.3496 & 0.3648 & 0.08 \\
\hline 1 & rs1801133 & $\mathrm{T}$ & C & $187 / 823 / 757$ & 0.4658 & 0.448 & 0.10 \\
\hline 10 & rs11003125 & C & G & $246 / 779 / 723$ & 0.4457 & 0.4628 & 0.12 \\
\hline 19 & rs1800469 & A & G & $148 / 676 / 924$ & 0.3867 & 0.4015 & 0.14 \\
\hline 1 & rs1801131 & G & $\mathrm{T}$ & $153 / 780 / 845$ & 0.4387 & 0.4243 & 0.16 \\
\hline 1 & rs1800871 & A & G & $74 / 622 / 1080$ & 0.3502 & 0.3396 & 0.21 \\
\hline 10 & rs1800451 & A & G & $1 / 45 / 1727$ & 0.02538 & 0.02616 & 0.27 \\
\hline 11 & rs602128 & G & A & $414 / 904 / 444$ & 0.5131 & 0.4999 & 0.27 \\
\hline 1 & rs3813946 & G & A & $77 / 551 / 1152$ & 0.3096 & 0.3176 & 0.30 \\
\hline 9 & rs4986790 & G & A & $3 / 191 / 1588$ & 0.1072 & 0.1044 & 0.36 \\
\hline 1 & rs6025 & A & G & 2/93/1694 & 0.05198 & 0.05275 & 0.38 \\
\hline 10 & rs5030737 & $\mathrm{T}$ & C & $6 / 238 / 1541$ & 0.1333 & 0.1302 & 0.46 \\
\hline 1 & rs1048971 & A & G & $226 / 796 / 755$ & 0.4479 & 0.4557 & 0.47 \\
\hline 4 & rs4961 & $\mathrm{T}$ & G & 70/541/1165 & 0.3046 & 0.3099 & 0.49 \\
\hline
\end{tabular}




\section{Chapter 3 Cohort Demographics}

\begin{tabular}{|c|c|c|c|c|c|c|c|}
\hline Chromosome & SNP & Allele 1 & Allele 2 & $\begin{array}{l}\text { Genotype } \\
\text { scores }\end{array}$ & $\begin{array}{c}\text { Observed } \\
\text { Heterozygous } \\
\text { frequency }\end{array}$ & $\begin{array}{l}\text { Expected } \\
\text { Hererozygous } \\
\text { Frequency }\end{array}$ & $P$ value \\
\hline 18 & rs6103 & G & C & $77 / 606 / 1089$ & 0.342 & 0.3369 & 0.57 \\
\hline 10 & rs1800450 & A & G & $32 / 432 / 1281$ & 0.2476 & 0.2438 & 0.62 \\
\hline 7 & rs1800795 & C & G & $329 / 857 / 586$ & 0.4836 & 0.4895 & 0.63 \\
\hline 7 & rs1800779 & G & A & $261 / 829 / 688$ & 0.4663 & 0.4712 & 0.65 \\
\hline 7 & rs16476 & G & $\mathrm{T}$ & $407 / 870 / 485$ & 0.4938 & 0.499 & 0.67 \\
\hline 18 & rs6098 & G & A & $76 / 587 / 1054$ & 0.3419 & 0.3378 & 0.67 \\
\hline 7 & rs16135 & A & G & $8 / 212 / 1561$ & 0.119 & 0.1198 & 0.69 \\
\hline 17 & rs1137933 & $\mathrm{T}$ & C & $97 / 653 / 1034$ & 0.366 & 0.3621 & 0.69 \\
\hline 6 & rs1800629 & A & G & $65 / 566 / 1144$ & 0.3189 & 0.3152 & 0.71 \\
\hline 2 & rs16944 & A & G & $186 / 759 / 804$ & 0.434 & 0.4376 & 0.74 \\
\hline 19 & rs429358 & C & $T$ & $33 / 428 / 1282$ & 0.2456 & 0.2433 & 0.77 \\
\hline 6 & rs1800610 & T & C & $15 / 288 / 1478$ & 0.1617 & 0.1626 & 0.77 \\
\hline 4 & rs4073 & A & $\mathrm{T}$ & $379 / 865 / 509$ & 0.4934 & 0.4973 & 0.77 \\
\hline 10 & rs7096206 & G & C & $85 / 601 / 1090$ & 0.3384 & 0.3399 & 0.83 \\
\hline 5 & rs2243250 & $\mathrm{T}$ & C & $37 / 434 / 1308$ & 0.244 & 0.2448 & 0.85 \\
\hline 19 & rs7412 & T & C & $10 / 237 / 1481$ & 0.1372 & 0.1377 & 0.86 \\
\hline 6 & rs361525 & A & G & $3 / 158 / 1627$ & 0.08837 & 0.08752 & 1.00 \\
\hline 10 & rs7095891 & A & G & $84 / 601 / 1075$ & 0.3415 & 0.3415 & 1.00 \\
\hline 11 & rs1799963 & A & G & $0 / 50 / 1744$ & 0.02787 & 0.02748 & 1.00 \\
\hline 19 & rs17516265 & C & A & 0/1/1770 & 0.000565 & 0.000565 & 1.00 \\
\hline 20 & rs1800576 & A & G & $0 / 16 / 1765$ & 0.008984 & 0.008943 & 1.00 \\
\hline 19 & rs1715 & T & $0 / 0 / 1785$ & 0 & 0 & 1 & \\
\hline
\end{tabular}

* $\mathrm{P}<0.05$, exclusion from analysis. 


\section{Chapter 3}

\section{Cohort Demographics}

\section{Figure 27}

Genotyping call cluster plot from Sequenom MassArray for rs1061170

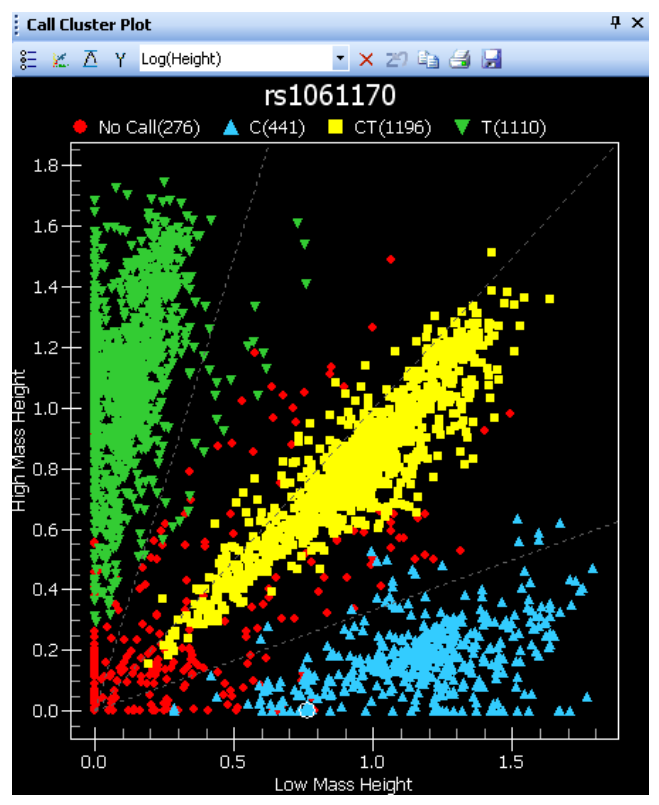

\section{Figure 28}

Genotyping call cluster plot from Sequenom MassArray for rs1800629

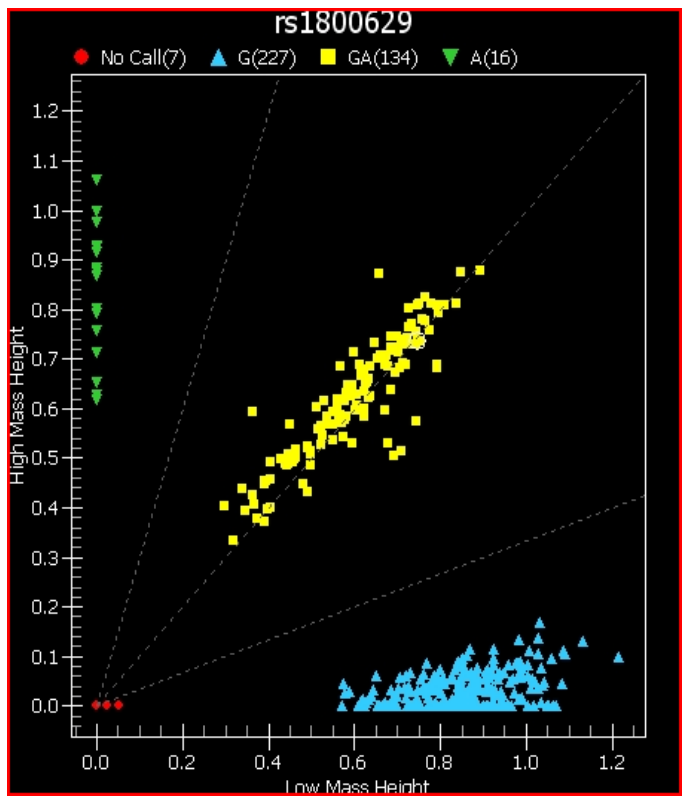




\section{Chapter 3 Cohort Demographics}

\section{Quality control of questionnaire data}

Security of questionnaires and consent forms was audited and $99.6 \%$ of hard copies were correctly located in lockup storage. Ten per cent of questionnaires and consent forms returned were randomly selected for data checking. Over the 33 questions per questionnaire, there was an average data entry error rate of $1.3 \%$ for those checked. Of the $1.3 \%$ of data points entered incorrectly, $67 \%$ of these errors affected the analysable data e.g. an incorrectly entered birth date would affect the analysable data as opposed to a misspelt address. The correct entry rate was therefore calculated at $99.06 \%$. For consent forms, the data entry error rate was calculated at $1.8 \%$ over the 18 fields with a correct entry of $99.95 \%$ when correcting for errors that did not affect the intent e.g. a misspelt address. 


\section{Chapter 3 Cohort Demographics}

\section{Conclusions}

The cohorts for the Australian Cerebral Palsy Research Study represent children of Caucasian origin, who were born in Australia between 1990 and 2005. Although similar to the Australian population, data relating to the control cohort must be interpreted with caution particularly for gender, gestational age, birth weight, maternal age and caesarean section or forceps delivery, as these are statistically significantly different to the Australian population data. Caution should also be used when interpreting data relating to the cases for gestational age subgroup 28-31 weeks, maternal age, cerebral palsy subtype and GMFCS levels as these are statistically significantly different to the cerebral palsy population data. The genotyping and data entry have been adequately assessed for systematic errors and exclusions made where necessary. The cohort is therefore suitable to test the hypotheses outlined in chapter 2. 
Chapter 3

Cohort Demographics 
Chapter $4 \quad$ Child's Genetics

Chapter 4 Genetic Association Study in Children 


\title{
Chapter $4 \quad$ Child's Genetics
}

\section{Fetal and Maternal Candidate SNP Associations with Cerebral Palsy in a Large Case-Control}

\section{Study*}

\author{
O'Callaghan $\mathrm{ME}^{1}$, MacLennan $\mathrm{AH}^{1}$, Gibson $\mathrm{CS}^{1}, \mathrm{McMichael} \mathrm{GL}^{1}$, Haan $\mathrm{EA}^{2}$, Broadbent $\mathrm{JL}^{1}$, \\ Goldwater $\mathrm{PN}^{3}$, Painter $\mathrm{JN}^{4}$, Montgomery $\mathrm{GW}^{4}$, Dekker $\mathrm{GA}^{1}$, for the Australian Collaborative \\ Cerebral Palsy Research Group.
}

Manuscript submitted for publication March 2011.

${ }^{1}$ Discipline of Obstetrics and Gynaecology, School of Paediatrics and Reproductive Health, The Robinson Institute, University of Adelaide, South Australia.

${ }^{2}$ SA Clinical Genetics Service, SA Pathology at Women's and Children's Hospital and Discipline of Paediatrics, The University of Adelaide, South Australia.

${ }^{3}$ Departments of Microbiology and Infectious Diseases, SA Pathology at Women's and Children's Hospital, South Australia.

${ }^{4}$ Molecular Epidemiology, Queensland Institute of Medical Research

* Submitted manuscript appears in this thesis as Chapters 4 and 5 
Chapter $4 \quad$ Child's Genetics

\section{Statement of authorship}

Fetal and Maternal Candidate SNP Associations with Cerebral Palsy in a Large Case-Control Study

Manuscript submitted for publication March 2011.

O'Callaghan ME (Candidate)

Participated in all aspects of this publication including the design, laboratory work, ethics submissions, recruitment, data linkage, statistical analysis, interpretation of the study and preparation of the manuscript.

I hereby certify that the statement of contribution is accurate

\section{MacLennan AH}

Principal supervisor, contributed to the study design, data interpretation and manuscript.

I hereby certify that the statement of contribution is accurate 


\section{Chapter $4 \quad$ Child's Genetics}

\section{Gibson CS}

Contributed to the study design, data interpretation and manuscript.

I hereby certify that the statement of contribution is accurate

\section{McMichael GL}

Contributed to the laboratory work and manuscript.

I hereby certify that the statement of contribution is accurate

\section{Haan EA}

Co-supervisor, contributed to the study design, data interpretation and manuscript.

I hereby certify that the statement of contribution is accurate 
Chapter $4 \quad$ Child's Genetics

\section{Broadbent J}

Contributed to the ethics submissions, participant recruitment and manuscript.

I hereby certify that the statement of contribution is accurate

\section{Goldwater PN}

Contributed to the study design, data interpretation and manuscript.

I hereby certify that the statement of contribution is accurate

\section{Painter JN}

Contributed to statistical analysis, data interpretation, preparation and approval of the final manuscript.

I hereby certify that the statement of contribution is accurate 


\section{Chapter $4 \quad$ Child's Genetics}

\section{Montgomery GW}

Contributed to statistical analysis, data interpretation, preparation and approval of the final manuscript.

I hereby certify that the statement of contribution is accurate

\section{Dekker GA}

Co-supervisor, contributed to the study design, data interpretation and manuscript.

I hereby certify that the statement of contribution is accurate

\section{The Australian Collaborative Cerebral Palsy Research Group}

A multidisciplinary group chaired by Professor Alastair MacLennan, who is Head of the Discipline of Obstetrics and Gynaecology in the School of Paediatrics and Reproductive Health at the University of Adelaide. All named authors of this paper are members of the group and wrote the paper on the group's behalf (group listed in acknowledgements). 
O'Callaghan, M.E., MacLennan, A.H., Gibson, C.S., McMichael, G.L., Haan, E.A., Broadbent, J.L., Goldwater, P.N., Painter, J.N., Montgomery, G.W. \& Dekker, G.A. (2012) Fetal and Maternal Candidate SNP Associations with Cerebral Palsy in a Large Case-Control Study Pediatrics, v. 129 (2), pp. E414-e423

\section{NOTE}

Published article is titled:

'Fetal and Maternal Candidate Single Nucleotide Polymorphism Associations with Cerebral Palsy: A Case-Control Study'.

\section{NOTE:}

This publication is included on pages $185-264$ in the print copy of the thesis held in the University of Adelaide Library.

It is also available online to authorised users at:

$$
\text { http://dx.doi.org/10.1542/peds.2011-0739 }
$$


Chapter $5 \quad$ Mother's Genetics

Chapter 5 Genetic Association Study in Mothers 
Chapter $5 \quad$ Mother's Genetics 


\section{Chapter $5 \quad$ Mother's Genetics}

\section{Abstract}

\section{Introduction}

This chapter addresses the primary and secondary aims set out in chapter two; to compare candidate SNPs in mothers who have a child with cerebral palsy versus controls. Specific tests include examination of immune related SNPs in mothers giving birth to quadriplegics after preterm delivery with a reported perinatal infection and thrombophilic SNPs in mothers giving birth to hemiplegics after term delivery with reported perinatal infection. Other secondary aims seek any maternal SNP associations with cerebral palsy subtype, gestational age subgroups, APOE genotypes and MBL haplotypes.

\section{Methods}

Primary and secondary hypotheses were tested by statistically examining potential maternal SNP associations with cerebral palsy along with pre-specified phenotypes and also subgroups by gestational age and cerebral palsy subtype. Association tests were made using a chi squared test and corrected for multiple comparisons using the Bonferroni method.

\section{Results}

Overall the 35 maternal candidate SNPs were not significantly associated with cerebral palsy after correction for multiple testing. Subgroup analysis considering specific phenotypes, cerebral palsy subtypes, gestational age subgroups, APOE genotypes and MBL haplotypes also showed no evidence of significant association after correction for multiple testing.

\section{Discussion}

Our results are in contrast to the one paper with a much smaller cohort published in this area. Allowance for multiple testing and larger numbers makes the influence on cerebral palsy of individual SNPs acting on their own unlikely. 


\section{Chapter 5 Mother's Genetics}

\section{Conclusions}

Maternal genotype was not associated with cerebral palsy in this cohort. 


\section{Chapter $5 \quad$ Mother's Genetics}

\section{Introduction}

SNP associations with cerebral palsy have been reported in 22 previous studies and were systematically reviewed in chapter one ${ }^{85}$. All associations reported to date have 1) had marginal $p$ values, 2) been reported in only one cohort and 3) been the result of numerous sub analyses. All reported associations required replication in larger independent cohorts.

Only one small study has examined maternal genotype as a potential risk factor for cerebral palsy in the child. Reid et al. ${ }^{44}$ examine maternal carriage of Factor V Leiden in 224 mothers of children with cerebral palsy. This cohort included cases with and without radiological evidence of a thrombotic event and Factor $V$ Leiden frequency was compared to historic population data. DNA was collected using buccal swabs and PCR used to detect FVL. FVL was found in $7.5 \%$ of mothers in their cohort, a statistically significant increase when compared to a presumed population frequency of $3.6 \%(p=0.021)$. This report is subject to bias as it used only historic population data as a comparison group rather than a prospectively genotyped cohort. The study lacks statistical power but is unlikely to be affected by multiple testing biases with only one SNP being examined.

Crider et al. provide indirect evidence of a link between maternal genotype and cerebral palsy by showing the maternal SNPs are a risk factor for preterm delivery in nine independent case control studies (for a HuGE systematic review of studies see ${ }^{103}$ ). This chapter describes an exploratory study examining 35 maternal SNPs in relation to cerebral palsy in the infant in a cohort of 587 cases and 1,154 controls, the largest cohort assembled to examine the genetics of cerebral palsy ${ }^{98}$. The primary and secondary aims are described in chapter two and those tested here are:

Primary aims:

1. To examine the association of specific maternal candidate SNPs with cerebral palsy 


\section{Chapter 5 Mother's Genetics}

2. To examine the association of specific maternal SNPs with prespecified phenotypes of cerebral palsy

Secondary aims:

1. To test maternal SNP associations with cerebral palsy by gestational age subgroups

2. To test maternal SNP associations with cerebral palsy by cerebral palsy subtype

3. To test maternal genotype associations of APOE with cerebral palsy and maternal haplotype associations of MBL with cerebral palsy. 


\section{Chapter $5 \quad$ Mother's Genetics}

\section{Methods}

Thirty-five SNP genotypes from 587 mothers with children who had cerebral palsy were compared to 1,154 control mothers who had children without cerebral palsy. SNP genotyping was performed by the Australian Genome Research Facility (AGRF, Brisbane Node, Australia) using the Sequenom MassArray Genotyper; quality control of the data is described in detail in chapter 3. The SNP panel is described in chapter 2 and includes candidate SNPs in the groups 1) thrombophilia 2) inflammation and 3) other risk factors for cerebral palsy, particularly adverse pregnancy outcomes such as preterm birth ${ }^{98}$.

Comparisons of minor allele frequency were made for each SNP by chi squared test using PLINK software (PLINK v1.07, Shaun Purcell, http://pngu.mgh.harvard.edu/purcell/plink/) ${ }^{99}$.

While most literature describing genetic associations with cerebral palsy has reported genotype frequencies, the wider genetic literature typically considers allele frequencies. Testing based on genotype associations allows for up to four comparisons to be made per SNP while testing based on allele frequencies allows only one. Since multiple testing has been a weakness of genetic studies reporting associations with cerebral palsy, allele frequency tests were selected for this study.

Significance levels were adjusted by Bonferroni correction to account for multiple testing. Of the 39 SNPs in the testing panel, one (Amelogenin) was included as an internal control and was not analysed. One (rs1715) was included inadvertently as the result of a transcription error, one (rs1061170) failed Hardy Weinberg equilibrium analysis and one was non-polymorphic (rs17516265). This left 35 SNPs to test. Linkage disequilibrium testing showed that two SNPs had a correlation of $>80 \%$ and could not be considered as independent tests ( $r s 6098$ and rs6103 both retained for completion). Bonferroni correction was therefore made for 34 SNPs where appropriate.

For each test the $p$ value is reported along with odds ratio and $95 \%$ confidence interval. 


\section{Chapter $5 \quad$ Mother's Genetics}

For APOE SNPs, genotype association tests were conducted as previously reported in the literature ${ }^{55}$. All APOE genotypes were compared by chi squared test with the APOE E3/E3 genotype. The presence or absence of perinatal infection was taken from the maternal questionnaire and perinatal outcomes statistics unit data described in chapter 2 . These tests were conducted in PASW Statistics 17.0.2 (SPSS Inc. Chicago, III).

For MBL SNPs, haplotype association tests were conducted as previously reported in the literature ${ }^{6}$. All MBL haplotypes were compared by chi squared test to the HYPA/HYPA haplotype. Associations were also made between groups of high, medium and low producing haplotypes of MBL as reported by de Messias-Reason, $2007^{80}$. The presence or absence of perinatal infection was taken from the maternal questionnaire and perinatal outcomes statistics unit data described in chapter 2. These tests were conducted in PASW Statistics 17.0.2 (SPSS Inc. Chicago, III). 
Chapter 5 Mother's Genetics

\section{Results}

\section{Primary aims}

Association with individual SNPs

Testing maternal SNP associations with cerebral palsy outcome did not reveal any significant associations. Chi squared and $p$ values are detailed for each SNP in Table 1 with the most significantly associated SNP having a p value of 0.005 ( $\mathrm{rs} 1800469$, odds ratio $1.25,95 \%$ confidence interval 1.07-1.46). Since 34 separate tests were conducted a significance of $p=$ 0.0014 would be required after Bonferroni correction. The odds ratios were mostly around 1 and ranged from 0.55-1.51. 
Table 1

Association test of maternal SNPs with cerebral palsy

\begin{tabular}{|c|c|c|c|c|c|c|c|c|c|c|c|}
\hline Chromosome & SNP & Gene & $\begin{array}{c}\text { Minor } \\
\text { allele// } \\
\text { Major allele }\end{array}$ & $\begin{array}{l}\text { Minor allele } \\
\text { frequency in } \\
\text { cases }\end{array}$ & $\begin{array}{l}\text { Minor allele } \\
\text { frequency in } \\
\text { controls }\end{array}$ & $\begin{array}{l}\text { Chi Squared } \\
\text { value }\end{array}$ & $P$ value & Odds Ratio & $\begin{array}{l}\text { Standard } \\
\text { Error }\end{array}$ & $\begin{array}{c}\text { Lower } 95 \% \\
\mathrm{Cl}\end{array}$ & $\begin{array}{c}\text { Upper 95\% } \\
\mathrm{Cl}\end{array}$ \\
\hline 1 & rs1801133 & MTHFR 677 & $T / C$ & 0.34 & 0.34 & 0.17 & 0.68 & 0.97 & 0.08 & 0.83 & 1.13 \\
\hline 1 & rs1801131 & MTHFR 1298 & $G / T$ & 0.31 & 0.30 & 0.35 & 0.55 & 1.05 & 0.08 & 0.90 & 1.22 \\
\hline 1 & rs6025 & FVL & $\mathrm{A} / \mathrm{G}$ & 0.03 & 0.02 & 3.90 & 0.05 & 1.51 & 0.21 & 1.00 & 2.28 \\
\hline 1 & rs1800871 & IL-10-819 & $A / G$ & 0.20 & 0.23 & 3.53 & 0.06 & 0.85 & 0.09 & 0.71 & 1.01 \\
\hline 1 & rs3813946 & CR2-1 & $\mathrm{G} / \mathrm{A}$ & 0.19 & 0.20 & 0.40 & 0.53 & 0.94 & 0.09 & 0.79 & 1.13 \\
\hline 1 & rs1048971 & CR2-2 & $\mathrm{A} / \mathrm{G}$ & 0.35 & 0.36 & 0.39 & 0.53 & 0.95 & 0.08 & 0.82 & 1.11 \\
\hline 2 & rs16944 & IL 1B +511 & $A / G$ & 0.31 & 0.33 & 2.19 & 0.14 & 0.89 & 0.08 & 0.76 & 1.04 \\
\hline 4 & rs4961 & ADD1 & $\mathrm{T} / \mathrm{G}$ & 0.19 & 0.20 & 0.09 & 0.76 & 0.97 & 0.09 & 0.81 & 1.16 \\
\hline 4 & rs4073 & IL-8 & $A / T$ & 0.47 & 0.46 & 0.04 & 0.85 & 1.01 & 0.07 & 0.88 & 1.17 \\
\hline 5 & rs2243250 & IL-4-589 & $T / C$ & 0.15 & 0.14 & 0.22 & 0.64 & 1.05 & 0.10 & 0.86 & 1.28 \\
\hline 5 & rs1042714 & ADRB2 Q27E & $\mathrm{G} / \mathrm{C}$ & 0.45 & 0.44 & 0.17 & 0.68 & 1.03 & 0.07 & 0.89 & 1.19 \\
\hline 6 & rs1800629 & TNF- $\alpha 308$ & $A / G$ & 0.18 & 0.20 & 2.61 & 0.11 & 0.86 & 0.09 & 0.72 & 1.03 \\
\hline 6 & rs361525 & TNF- $\alpha-238$ & $A / G$ & 0.04 & 0.05 & 0.27 & 0.60 & 0.91 & 0.18 & 0.65 & 1.29 \\
\hline 6 & rs1800610 & TNF- $\alpha+488$ & $\mathrm{~T} / \mathrm{C}$ & 0.09 & 0.09 & $<0.005$ & 0.95 & 0.99 & 0.13 & 0.77 & 1.27 \\
\hline 7 & rs1800795 & IL-6-174 & $\mathrm{C} / \mathrm{G}$ & 0.42 & 0.43 & 0.35 & 0.56 & 0.96 & 0.07 & 0.83 & 1.11 \\
\hline 7 & rs16135 & NPY C4112T & $A / G$ & 0.07 & 0.06 & 1.68 & 0.19 & 1.20 & 0.14 & 0.91 & 1.59 \\
\hline
\end{tabular}




\begin{tabular}{|c|c|c|c|c|c|c|c|c|c|c|c|}
\hline Chromosome & SNP & Gene & $\begin{array}{c}\text { Minor } \\
\text { allele/ } \\
\text { Major allele }\end{array}$ & $\begin{array}{l}\text { Minor allele } \\
\text { frequency in } \\
\text { cases }\end{array}$ & $\begin{array}{l}\text { Minor allele } \\
\text { frequency in } \\
\text { controls }\end{array}$ & $\begin{array}{l}\text { Chi Squared } \\
\text { value }\end{array}$ & P value & Odds Ratio & $\begin{array}{l}\text { Standard } \\
\text { Error }\end{array}$ & $\begin{array}{c}\text { Lower } 95 \% \\
\mathrm{Cl}\end{array}$ & $\begin{array}{l}\text { Upper 95\% } \\
\text { CI }\end{array}$ \\
\hline 7 & rs16476 & NPY A6411C & $\mathrm{G} / \mathrm{T}$ & 0.47 & 0.48 & 0.62 & 0.43 & 0.94 & 0.07 & 0.82 & 1.09 \\
\hline 7 & rs1800779 & eNOS-922 & G/A & 0.39 & 0.38 & 0.34 & 0.56 & 1.04 & 0.07 & 0.90 & 1.21 \\
\hline 9 & rs 4986790 & TLR4 299 & $G / A$ & 0.06 & 0.05 & 0.04 & 0.84 & 1.03 & 0.16 & 0.76 & 1.40 \\
\hline 10 & rs1800451 & MBL codon 57 & $A / G$ & 0.01 & 0.01 & 0.14 & 0.70 & 0.88 & 0.34 & 0.46 & 1.70 \\
\hline 10 & rs 1800450 & MBL codon 54 & $\mathrm{~A} / \mathrm{G}$ & 0.14 & 0.14 & 0.35 & 0.56 & 0.94 & 0.11 & 0.76 & 1.16 \\
\hline 10 & rs5030737 & MBL codon 52 & $T / C$ & 0.08 & 0.06 & 3.86 & 0.05 & 1.31 & 0.14 & 1.00 & 1.71 \\
\hline 10 & rs7095891 & $\mathrm{MBL}+4$ & $A / G$ & 0.19 & 0.23 & 5.18 & 0.02 & 0.82 & 0.09 & 0.68 & 0.97 \\
\hline 10 & rs7096206 & MBL-221 & $\mathrm{G} / \mathrm{C}$ & 0.23 & 0.21 & 0.71 & 0.40 & 1.08 & 0.09 & 0.91 & 1.28 \\
\hline 10 & rs11003125 & MBL-550 & $\mathrm{C} / \mathrm{G}$ & 0.39 & 0.36 & 3.68 & 0.05 & 1.16 & 0.08 & 1.00 & 1.34 \\
\hline 11 & rs1799963 & PGM & $\mathrm{A} / \mathrm{G}$ & 0.02 & 0.01 & 0.90 & 0.34 & 1.32 & 0.29 & 0.74 & 2.33 \\
\hline 11 & rs 602128 & MMP-3 & $\mathrm{G} / \mathrm{A}$ & 0.50 & 0.49 & 0.29 & 0.59 & 1.04 & 0.07 & 0.90 & 1.20 \\
\hline 16 & rs243865 & MMP-2 & $T / C$ & 0.25 & 0.23 & 0.93 & 0.33 & 1.08 & 0.08 & 0.92 & 1.28 \\
\hline 17 & rs1137933 & iNOS(NOS2A) & $\mathrm{T} / \mathrm{C}$ & 0.22 & 0.25 & 2.30 & 0.13 & 0.88 & 0.09 & 0.74 & 1.04 \\
\hline 18 & rs6098 & PAl-2_1 & $\mathrm{G} / \mathrm{A}$ & 0.20 & 0.22 & 2.43 & 0.12 & 0.87 & 0.09 & 0.73 & 1.04 \\
\hline 18 & rs6103 & PAl-2_2 & $\mathrm{G} / \mathrm{C}$ & 0.20 & 0.22 & 2.96 & 0.09 & 0.86 & 0.09 & 0.72 & 1.02 \\
\hline 19 & rs1800469 & TGF-B1-509 & $\mathrm{A} / \mathrm{G}$ & 0.31 & 0.26 & 7.73 & 0.01 & 1.25 & 0.08 & 1.07 & 1.46 \\
\hline 19 & rs429358 & APO-E_1 & $C / T$ & 0.14 & 0.14 & 0.01 & 0.93 & 0.99 & 0.10 & 0.81 & 1.22 \\
\hline 19 & rs7412 & APO-E_2 & $T / C$ & 0.07 & 0.08 & 0.20 & 0.66 & 0.94 & 0.14 & 0.71 & 1.24 \\
\hline 20 & rs1800576 & THBD & $\mathrm{A} / \mathrm{G}$ & $<0.005$ & 0.01 & 1.09 & 0.30 & 0.56 & 0.57 & 0.18 & 1.70 \\
\hline
\end{tabular}




\section{Chapter 5 Mother's Genetics}

\section{Association with pre-specified phenotypes}

Based upon previous studies, two specific phenotypes of cerebral palsy were of interest as part of the primary aims of the study. Firstly, quadriplegia in preterm infants (born at less than 32 weeks gestational age) with a reported infection during pregnancy and association with immune-related SNPs and secondly, hemiplegia in term infants (born at or after 37 weeks gestational age) with a reported infection during pregnancy and association with thrombophilic SNPs. Chapter 2 lists the breakdown of immune-related and thrombophilic SNPs used for these tests ${ }^{98}$.

Table 2 lists the chi squared and $p$ values for immune-related SNPs in association with quadriplegia in preterm infants with a reported infection. The lowest $p$ value was 0.02 (rs1800871, odds ratio $0.28,95 \%$ confidence interval 0.085-0.9). After Bonferroni correction a value of 0.002 would be required to reach significance (21 SNP tests) and this was not achieved in any test. Again all odds ratios were close to unity 
Table 2

Association test of immune-related SNPs between mothers giving birth to quadriplegics after preterm delivery with a reported perinatal infection (21)

and controls (1154)

\begin{tabular}{|c|c|c|c|c|c|c|c|c|c|c|c|}
\hline Chromosome & SNP & Gene & $\begin{array}{c}\text { Minor } \\
\text { allele/ } \\
\text { Major allele }\end{array}$ & $\begin{array}{l}\text { Minor allele } \\
\text { frequency in } \\
\text { cases }\end{array}$ & $\begin{array}{l}\text { Minor allele } \\
\text { frequency in } \\
\text { controls }\end{array}$ & $\begin{array}{l}\text { Chi Squared } \\
\text { value }\end{array}$ & $P$ value & Odds Ratio & $\begin{array}{c}\text { Standard } \\
\text { Error }\end{array}$ & $\begin{array}{c}\text { Lower 95\% } \\
\text { Cl }\end{array}$ & $\begin{array}{c}\text { Upper 95\% } \\
\mathrm{Cl}\end{array}$ \\
\hline 1 & rs1800871 & IL-10-819 & $\mathrm{A} / \mathrm{G}$ & 0.08 & 0.23 & 5.21 & 0.02 & 0.28 & 0.60 & 0.08 & 0.90 \\
\hline 1 & rs3813946 & CR2-1 & G/A & 0.26 & 0.20 & 0.89 & 0.35 & 1.39 & 0.35 & 0.70 & 2.79 \\
\hline 1 & rs1048971 & CR2-2 & $\mathrm{A} / \mathrm{G}$ & 0.38 & 0.36 & 0.10 & 0.76 & 1.11 & 0.32 & 0.59 & 2.07 \\
\hline 2 & rs16944 & IL $1 \mathrm{~B}+511$ & $\mathrm{~A} / \mathrm{G}$ & 0.26 & 0.33 & 0.91 & 0.34 & 0.71 & 0.35 & 0.36 & 1.43 \\
\hline 4 & rs4073 & IL-8 & $\mathrm{A} / \mathrm{T}$ & 0.56 & 0.46 & 1.24 & 0.27 & 1.46 & 0.34 & 0.75 & 2.82 \\
\hline 5 & rs 2243250 & IL-4-589 & $\mathrm{T} / \mathrm{C}$ & 0.10 & 0.14 & 0.54 & 0.46 & 0.68 & 0.53 & 0.24 & 1.92 \\
\hline 6 & rs 1800629 & TNF- $\alpha 308$ & $A / G$ & 0.28 & 0.20 & 1.22 & 0.27 & 1.48 & 0.36 & 0.73 & 2.99 \\
\hline 6 & rs361525 & TNF- $\alpha-238$ & $\mathrm{~A} / \mathrm{G}$ & 0.02 & 0.05 & 0.48 & 0.49 & 0.50 & 1.02 & 0.07 & 3.67 \\
\hline 6 & rs1800610 & TNF- $\alpha+488$ & $T / C$ & 0.12 & 0.09 & 0.47 & 0.49 & 1.39 & 0.48 & 0.54 & 3.58 \\
\hline 7 & rs1800795 & IL-6-174 & $\mathrm{C} / \mathrm{G}$ & 0.30 & 0.43 & 2.73 & 0.10 & 0.57 & 0.35 & 0.29 & 1.12 \\
\hline 9 & rs4986790 & TLR4 299 & G/A & 0.05 & 0.05 & 0.04 & 0.84 & 0.86 & 0.73 & 0.21 & 3.61 \\
\hline 10 & rs1800451 & MBL codon 57 & $\mathrm{~A} / \mathrm{G}$ & 0.02 & 0.01 & 0.40 & 0.53 & 1.90 & 1.03 & 0.25 & 14.27 \\
\hline 10 & rs 1800450 & MBL codon 54 & $\mathrm{~A} / \mathrm{G}$ & 0.15 & 0.14 & 0.01 & 0.90 & 1.06 & 0.45 & 0.44 & 2.54 \\
\hline 10 & rs5030737 & MBL codon 52 & $T / C$ & 0.07 & 0.06 & 0.05 & 0.83 & 1.14 & 0.61 & 0.35 & 3.74 \\
\hline 10 & rs7095891 & $\mathrm{MBL}+4$ & $A / G$ & 0.26 & 0.23 & 0.27 & 0.61 & 1.20 & 0.35 & 0.60 & 2.41 \\
\hline
\end{tabular}




\begin{tabular}{|c|c|c|c|c|c|c|c|c|c|c|c|}
\hline Chromosome & SNP & Gene & $\begin{array}{c}\text { Minor } \\
\text { allele/ } \\
\text { Major allele }\end{array}$ & $\begin{array}{l}\text { Minor allele } \\
\text { frequency in } \\
\text { cases }\end{array}$ & $\begin{array}{l}\text { Minor allele } \\
\text { frequency in } \\
\text { controls }\end{array}$ & $\begin{array}{l}\text { Chi Squared } \\
\text { value }\end{array}$ & $P$ value & Odds Ratio & $\begin{array}{l}\text { Standard } \\
\text { Error }\end{array}$ & $\begin{array}{c}\text { Lower 95\% } \\
\mathrm{Cl}\end{array}$ & $\begin{array}{c}\text { Upper } 95 \% \\
\text { Cl }\end{array}$ \\
\hline 10 & rs7096206 & MBL-221 & $\mathrm{G} / \mathrm{C}$ & 0.21 & 0.21 & $<0.005$ & 1.00 & 1.00 & 0.38 & 0.48 & 2.11 \\
\hline 10 & rs11003125 & MBL-550 & $C / G$ & 0.38 & 0.36 & 0.07 & 0.80 & 1.09 & 0.33 & 0.57 & 2.08 \\
\hline 11 & rs602128 & MMP-3 & $\mathrm{G} / \mathrm{A}$ & 0.57 & 0.49 & 1.21 & 0.27 & 1.41 & 0.31 & 0.76 & 2.61 \\
\hline 16 & rs243865 & MMP-2 & $T / C$ & 0.19 & 0.23 & 0.42 & 0.52 & 0.77 & 0.40 & 0.36 & 1.68 \\
\hline 19 & rs1800469 & TGF-B1-509 & $\mathrm{A} / \mathrm{G}$ & 0.29 & 0.26 & 0.11 & 0.74 & 1.12 & 0.34 & 0.57 & 2.21 \\
\hline
\end{tabular}




\section{Chapter $5 \quad$ Mother's Genetics}

Table 3 lists the chi squared and $p$ values for thrombophilic SNPs in association with hemiplegia in term infants with a reported infection. No SNPs were significant at the $p=0.05$ level. All odds ratios were close to unity except Prothrombin gene mutation which had an odds ratio of $2.35,95 \%$ confidence interval $0.70-7.82, p=0.15$. 
Table 3

Association test of thrombophilic SNPs between mothers giving birth to hemiplegics after term delivery with reported perinatal infection (51) and

\begin{tabular}{|c|c|c|c|c|c|c|c|c|c|c|c|}
\hline Chromosome & SNP & Gene & $\begin{array}{c}\text { Minor } \\
\text { allele/ } \\
\text { Major allele }\end{array}$ & $\begin{array}{l}\text { Minor allele } \\
\text { frequency in } \\
\text { cases }\end{array}$ & $\begin{array}{l}\text { Minor allele } \\
\text { frequency in } \\
\text { controls }\end{array}$ & $\begin{array}{l}\text { Chi Squared } \\
\text { value }\end{array}$ & $P$ value & Odds Ratio & $\begin{array}{l}\text { Standard } \\
\text { Error }\end{array}$ & $\begin{array}{c}\text { Lower 95\% } \\
\mathrm{Cl}\end{array}$ & $\begin{array}{c}\text { Upper } 95 \% \\
\mathrm{Cl}\end{array}$ \\
\hline 1 & rs1801133 & MTHFR 677 & $\mathrm{~T} / \mathrm{C}$ & 0.27 & 0.34 & 2.29 & 0.13 & 0.71 & 0.23 & 0.45 & 1.11 \\
\hline 1 & rs1801131 & MTHFR 1298 & $\mathrm{G} / \mathrm{T}$ & 0.34 & 0.30 & 0.67 & 0.41 & 1.19 & 0.22 & 0.78 & 1.82 \\
\hline 1 & rs6025 & FVL & $\mathrm{A} / \mathrm{G}$ & 0.03 & 0.02 & 0.15 & 0.70 & 1.26 & 0.60 & 0.39 & 4.11 \\
\hline 7 & rs16135 & NPY C4112T & $A / G$ & 0.08 & 0.06 & 0.52 & 0.47 & 1.31 & 0.38 & 0.63 & 2.76 \\
\hline 7 & rs16476 & NPY A6411C & $\mathrm{G} / \mathrm{T}$ & 0.49 & 0.48 & 0.01 & 0.92 & 1.02 & 0.20 & 0.68 & 1.53 \\
\hline 11 & rs1799963 & PGM & $A / G$ & 0.03 & 0.01 & 2.05 & 0.15 & 2.35 & 0.61 & 0.70 & 7.82 \\
\hline 18 & rs6098 & PAI-2_1 & G/A & 0.17 & 0.22 & 1.35 & 0.25 & 0.73 & 0.27 & 0.43 & 1.24 \\
\hline 18 & rs6103 & PAl-2_2 & $\mathrm{G} / \mathrm{C}$ & 0.16 & 0.22 & 2.20 & 0.14 & 0.66 & 0.28 & 0.39 & 1.15 \\
\hline 20 & rs1800576 & THBD & $A / G$ & $<0.005$ & 0.01 & 0.63 & 0.43 & $<0.005$ & $\inf$ & $<0.005$ & nan \\
\hline
\end{tabular}




\section{Chapter $5 \quad$ Mother's Genetics}

\section{Secondary aims}

Test of association by gestational age

Comparison of cases and controls born at less than 32 weeks gestational age

Table 4 reports comparison of all maternal SNPs between cases and controls born before 32 weeks gestational age with four SNPs showing significant association with cerebral palsy at the $p=0.05$ level. These SNPs were iNOS $(p=0.039$, odds ratio $0.35,95 \%$ confidence interval 0.12 $0.99)$, PAI-2_1 ( $p=0.001$, odds ratio $0.21,95 \%$ confidence interval $0.07-0.57)$, PAI-2_2 ( $p=0.001$, odds ratio $0.21,95 \%$ confidence interval $0.07-0.58)$ and TGF-B1-509 $(p=0.003$, odds ratio 0.22 , $95 \%$ confidence interval $0.07-0.65)$. Since this test contributed to 340 tests in the secondary aims, it was appropriate to use a Bonferroni correction to set the significance rate at 0.0001 . No SNPs were significant at this level and most odds ratios were close to unity. The small number of controls meeting these criteria weakens these comparisons. 
Table 4

Comparison of cases and controls born at less than 32 weeks gestational age. 167 cases and 8 controls met the criteria for inclusion.

\begin{tabular}{|c|c|c|c|c|c|c|c|c|c|c|c|}
\hline Chromosome & SNP & Gene & $\begin{array}{l}\text { Minor allele/ } \\
\text { Major allele }\end{array}$ & $\begin{array}{l}\text { Minor allele } \\
\text { frequency in cases }\end{array}$ & $\begin{array}{l}\text { Minor allele } \\
\text { frequency in } \\
\text { controls }\end{array}$ & $\begin{array}{l}\text { Chi Squared } \\
\text { value }\end{array}$ & Pvalue & Odds Ratio & $\begin{array}{l}\text { Standard } \\
\text { Error }\end{array}$ & $\begin{array}{l}\text { Lower } \\
95 \% \mathrm{Cl}\end{array}$ & $\begin{array}{l}\text { Upper } \\
95 \% \mathrm{CI}\end{array}$ \\
\hline 1 & rs1801133 & MTHFR 677 & $T / C$ & 0.36 & 0.31 & 0.17 & 0.68 & 1.25 & 0.55 & 0.43 & 3.69 \\
\hline 1 & rs1801131 & MTHFR 1298 & $\mathrm{G} / \mathrm{T}$ & 0.29 & 0.31 & 0.03 & 0.86 & 0.91 & 0.55 & 0.31 & 2.68 \\
\hline 1 & rs6025 & FVL & $A / G$ & 0.05 & $<0.005$ & 0.80 & 0.37 & NA & NA & NA & NA \\
\hline 1 & rs1800871 & IL-10-819 & $A / G$ & 0.18 & 0.25 & 0.47 & 0.49 & 0.67 & 0.59 & 0.21 & 2.14 \\
\hline 1 & rs3813946 & CR2-1 & $\mathrm{G} / \mathrm{A}$ & 0.21 & 0.13 & 0.64 & 0.42 & 1.84 & 0.77 & 0.41 & 8.27 \\
\hline 1 & rs1048971 & CR2-2 & $A / G$ & 0.36 & 0.38 & 0.01 & 0.91 & 0.94 & 0.53 & 0.33 & 2.65 \\
\hline 2 & rs 16944 & IL 1 B +511 & $A / G$ & 0.31 & 0.31 & $<0.005$ & 0.97 & 0.98 & 0.55 & 0.33 & 2.90 \\
\hline 4 & rs4961 & ADD1 & $T / G$ & 0.17 & $<0.005$ & 3.29 & 0.07 & NA & NA & NA & NA \\
\hline 4 & rs4073 & IL-8 & $A / T$ & 0.45 & 0.57 & 0.75 & 0.39 & 0.62 & 0.55 & 0.21 & 1.83 \\
\hline 5 & rs2243250 & IL-4-589 & $T / C$ & 0.16 & 0.19 & 0.06 & 0.81 & 0.85 & 0.66 & 0.24 & 3.10 \\
\hline 5 & rs1042714 & ADRB2 Q27E & $\mathrm{G} / \mathrm{C}$ & 0.49 & 0.38 & 0.82 & 0.37 & 1.61 & 0.53 & 0.57 & 4.52 \\
\hline 6 & rs1800629 & TNF- $\alpha 308$ & $\mathrm{~A} / \mathrm{G}$ & 0.18 & 0.07 & 1.03 & 0.31 & 2.77 & 1.05 & 0.36 & 21.61 \\
\hline 6 & rs 361525 & TNF- $\alpha-238$ & $\mathrm{~A} / \mathrm{G}$ & 0.04 & $<0.005$ & 0.60 & 0.44 & NA & NA & NA & NA \\
\hline 6 & rs1800610 & TNF- $\alpha+488$ & $T / C$ & 0.09 & 0.13 & 0.26 & 0.61 & 0.67 & 0.78 & 0.15 & 3.11 \\
\hline 7 & rs1800795 & IL-6-174 & $\mathrm{C} / \mathrm{G}$ & 0.39 & 0.38 & 0.01 & 0.91 & 1.06 & 0.53 & 0.38 & 2.98 \\
\hline 7 & rs16135 & NPY C4112T & $\mathrm{A} / \mathrm{G}$ & 0.07 & 0.13 & 0.61 & 0.43 & 0.55 & 0.79 & 0.12 & 2.54 \\
\hline 7 & rs16476 & NPY A6411C & $\mathrm{G} / \mathrm{T}$ & 0.49 & 0.44 & 0.17 & 0.68 & 1.24 & 0.52 & 0.45 & 3.41 \\
\hline
\end{tabular}




\begin{tabular}{|c|c|c|c|c|c|c|c|c|c|c|c|}
\hline Chromosome & SNP & Gene & $\begin{array}{l}\text { Minor allele/ } \\
\text { Major allele }\end{array}$ & $\begin{array}{l}\text { Minor allele } \\
\text { frequency in cases }\end{array}$ & $\begin{array}{l}\text { Minor allele } \\
\text { frequency in } \\
\text { controls }\end{array}$ & $\begin{array}{l}\text { Chi Squared } \\
\text { value }\end{array}$ & P value & Odds Ratio & $\begin{array}{l}\text { Standard } \\
\text { Error }\end{array}$ & $\begin{array}{l}\text { Lower } \\
95 \% \mathrm{Cl}\end{array}$ & $\begin{array}{l}\text { Upper } \\
95 \% \mathrm{CI}\end{array}$ \\
\hline 7 & rs1800779 & eNOS-922 & $\mathrm{G} / \mathrm{A}$ & 0.42 & 0.50 & 0.40 & 0.53 & 0.72 & 0.51 & 0.27 & 1.98 \\
\hline 9 & rs 4986790 & TLR4 299 & $\mathrm{G} / \mathrm{A}$ & 0.06 & 0.06 & 0.01 & 0.92 & 0.90 & 1.06 & 0.11 & 7.22 \\
\hline 10 & rs 1800451 & $\begin{array}{l}\text { MBL codon } \\
57\end{array}$ & $A / G$ & 0.01 & $<0.005$ & 0.10 & 0.75 & NA & NA & NA & NA \\
\hline 10 & rs 1800450 & $\begin{array}{l}\text { MBL codon } \\
54\end{array}$ & $A / G$ & 0.17 & 0.19 & 0.05 & 0.82 & 0.86 & 0.66 & 0.24 & 3.12 \\
\hline 10 & rs5030737 & $\begin{array}{l}\text { MBL codon } \\
52\end{array}$ & $T / C$ & 0.07 & 0.06 & 0.02 & 0.89 & 1.16 & 1.05 & 0.15 & 9.17 \\
\hline 10 & rs7095891 & $\mathrm{MBL}+4$ & $\mathrm{~A} / \mathrm{G}$ & 0.16 & 0.25 & 0.91 & 0.34 & 0.57 & 0.60 & 0.18 & 1.83 \\
\hline 10 & rs7096206 & MBL-221 & $\mathrm{G} / \mathrm{C}$ & 0.21 & 0.25 & 0.18 & 0.67 & 0.78 & 0.59 & 0.24 & 2.49 \\
\hline 10 & rs11003125 & MBL-550 & $C / G$ & 0.40 & 0.25 & 1.51 & 0.22 & 2.03 & 0.59 & 0.64 & 6.44 \\
\hline 11 & rs1799963 & PGM & $\mathrm{A} / \mathrm{G}$ & 0.02 & $<0.005$ & 0.34 & 0.56 & NA & NA & NA & NA \\
\hline 11 & rs602128 & MMP-3 & $\mathrm{G} / \mathrm{A}$ & 0.48 & 0.44 & 0.12 & 0.73 & 1.20 & 0.52 & 0.44 & 3.29 \\
\hline 16 & rs 243865 & MMP-2 & $T / C$ & 0.24 & 0.19 & 0.25 & 0.62 & 1.39 & 0.65 & 0.39 & 4.99 \\
\hline 17 & rs1137933 & iNOS(NOS2A) & $T / C$ & 0.17 & 0.38 & 4.26 & 0.04 & 0.35 & 0.54 & 0.12 & 0.99 \\
\hline 18 & rs6098 & PAl-2_1 & G/A & 0.21 & 0.56 & 10.82 & 0.001 & 0.21 & 0.52 & 0.07 & 0.57 \\
\hline 18 & rs6103 & PAl-2_2 & $\mathrm{G} / \mathrm{C}$ & 0.21 & 0.56 & 10.76 & 0.001 & 0.21 & 0.52 & 0.07 & 0.58 \\
\hline 19 & rs1800469 & TGF-B1-509 & $A / G$ & 0.33 & 0.69 & 8.90 & 0.002 & 0.22 & 0.55 & 0.07 & 0.65 \\
\hline 19 & rs429358 & APO-E_1 & $\mathrm{C} / \mathrm{T}$ & 0.15 & 0.25 & 1.26 & 0.26 & 0.52 & 0.60 & 0.16 & 1.67 \\
\hline 19 & rs7412 & APO-E_2 & $T / C$ & 0.07 & 0.13 & 0.86 & 0.35 & 0.49 & 0.79 & 0.10 & 2.29 \\
\hline 20 & rs1800576 & THBD & $A / G$ & $<0.005$ & $<0.005$ & 0.05 & 0.83 & NA & NA & NA & NA \\
\hline
\end{tabular}




\section{Chapter $5 \quad$ Mother's Genetics}

Comparison of cases born before 32 weeks and all controls

Table 5 reports comparison of all maternal SNPs between cases born before 32 weeks gestational age and all controls with four SNPs showing significant association with cerebral palsy at the $p=0.05$ level. These SNPs were FVL $(p=0.01$, odds ratio $2.10,95 \%$ confidence interval 1.193.71), MBL+4 ( $p=0.005$, odds ratio $0.64,95 \%$ confidence interval $0.47-0.88)$, iNOS ( $p=0.003$, odds ratio $0.64,95 \%$ confidence interval $0.47-0.86)$ and TGF-B1-509 $(p=0.02$, odds ratio $1.35,95 \%$ confidence interval 1.05-1.74). Since this test contributed to 340 tests in the secondary aims, it was appropriate to use a Bonferroni correction to set the significance rate at 0.0001 . No SNPs were significant at this level and all odds ratios were close to unity. 
Table 5.

Comparison of cases born before 32 weeks gestational age $(167)$ and all controls $(1,154)$

\begin{tabular}{|c|c|c|c|c|c|c|c|c|c|c|c|}
\hline Chromosome & SNP & Gene & $\begin{array}{l}\text { Minor allele/ Major } \\
\text { allele }\end{array}$ & $\begin{array}{c}\text { Minor allele } \\
\text { frequency in cases }\end{array}$ & $\begin{array}{l}\text { Minor allele frequency } \\
\text { in controls }\end{array}$ & $\begin{array}{l}\text { Chi Squared } \\
\text { value }\end{array}$ & P value & $\begin{array}{l}\text { Odds } \\
\text { Ratio }\end{array}$ & $\begin{array}{l}\text { Standard } \\
\text { Error }\end{array}$ & $\begin{array}{l}\text { Lower 95\% } \\
\quad \mathrm{CI}\end{array}$ & $\begin{array}{l}\text { Upper 95\% } \\
\text { Cl }\end{array}$ \\
\hline 1 & rs1801133 & MTHFR 677 & $\mathrm{~T} / \mathrm{C}$ & 0.36 & 0.34 & 0.48 & 0.49 & 1.09 & 0.12 & 0.86 & 1.39 \\
\hline 1 & rs1801131 & MTHFR 1298 & $\mathrm{G} / \mathrm{T}$ & 0.29 & 0.30 & 0.12 & 0.73 & 0.96 & 0.13 & 0.74 & 1.23 \\
\hline 1 & rs6025 & FVL & $A / G$ & 0.05 & 0.02 & 6.76 & 0.01 & 2.10 & 0.29 & 1.19 & 3.71 \\
\hline 1 & rs1800871 & IL-10-819 & $\mathrm{A} / \mathrm{G}$ & 0.18 & 0.23 & 3.39 & 0.07 & 0.76 & 0.15 & 0.56 & 1.02 \\
\hline 1 & rs3813946 & CR2-1 & $\mathrm{G} / \mathrm{A}$ & 0.21 & 0.20 & 0.04 & 0.83 & 1.03 & 0.14 & 0.78 & 1.37 \\
\hline 1 & rs1048971 & CR2-2 & $A / G$ & 0.36 & 0.36 & 0.01 & 0.92 & 1.01 & 0.12 & 0.80 & 1.29 \\
\hline 2 & rs16944 & IL 1B +511 & $\mathrm{A} / \mathrm{G}$ & 0.31 & 0.33 & 0.68 & 0.41 & 0.90 & 0.13 & 0.70 & 1.16 \\
\hline 4 & rs4961 & ADD1 & $T / G$ & 0.17 & 0.20 & 1.02 & 0.31 & 0.86 & 0.15 & 0.63 & 1.16 \\
\hline 4 & rs4073 & IL-8 & $A / T$ & 0.45 & 0.46 & 0.09 & 0.77 & 0.97 & 0.12 & 0.76 & 1.22 \\
\hline 5 & rs2243250 & IL-4-589 & $\mathrm{T} / \mathrm{C}$ & 0.16 & 0.14 & 1.32 & 0.25 & 1.20 & 0.16 & 0.88 & 1.65 \\
\hline 5 & rs1042714 & ADRB2 Q27E & $\mathrm{G} / \mathrm{C}$ & 0.49 & 0.44 & 3.22 & 0.07 & 1.24 & 0.12 & 0.98 & 1.56 \\
\hline 6 & rs1800629 & TNF- $\alpha 308$ & $\mathrm{~A} / \mathrm{G}$ & 0.18 & 0.20 & 1.42 & 0.23 & 0.83 & 0.15 & 0.62 & 1.13 \\
\hline 6 & rs 361525 & TNF- $\alpha-238$ & $\mathrm{~A} / \mathrm{G}$ & 0.04 & 0.05 & 0.75 & 0.39 & 0.76 & 0.31 & 0.42 & 1.40 \\
\hline 6 & rs 1800610 & TNF- $\alpha+488$ & $T / C$ & 0.09 & 0.09 & $<0.005$ & 0.96 & 0.99 & 0.21 & 0.66 & 1.49 \\
\hline 7 & rs 1800795 & IL-6-174 & C/G & 0.39 & 0.43 & 2.08 & 0.15 & 0.84 & 0.12 & 0.66 & 1.06 \\
\hline 7 & rs16135 & NPY C4112T & $A / G$ & 0.07 & 0.06 & 0.65 & 0.42 & 1.20 & 0.23 & 0.77 & 1.89 \\
\hline 7 & rs16476 & NPY A6411C & $\mathrm{G} / \mathrm{T}$ & 0.49 & 0.48 & 0.04 & 0.83 & 1.03 & 0.12 & 0.81 & 1.29 \\
\hline
\end{tabular}




\begin{tabular}{|c|c|c|c|c|c|c|c|c|c|c|c|}
\hline Chromosome & SNP & Gene & $\begin{array}{l}\text { Minor allele/ Major } \\
\text { allele }\end{array}$ & $\begin{array}{l}\text { Minor allele } \\
\text { frequency in cases }\end{array}$ & $\begin{array}{l}\text { Minor allele frequency } \\
\text { in controls }\end{array}$ & $\begin{array}{l}\text { Chi Squared } \\
\text { value }\end{array}$ & P value & $\begin{array}{l}\text { Odds } \\
\text { Ratio }\end{array}$ & $\begin{array}{l}\text { Standard } \\
\text { Error }\end{array}$ & $\begin{array}{l}\text { Lower 95\% } \\
\quad \text { CI }\end{array}$ & $\begin{array}{l}\text { Upper 95\% } \\
\text { CI }\end{array}$ \\
\hline 7 & rs1800779 & eNOS-922 & $\mathrm{G} / \mathrm{A}$ & 0.42 & 0.38 & 2.19 & 0.14 & 1.19 & 0.12 & 0.94 & 1.51 \\
\hline 9 & rs4986790 & TLR4 299 & G/A & 0.06 & 0.05 & 0.02 & 0.87 & 1.04 & 0.25 & 0.63 & 1.71 \\
\hline 10 & rs1800451 & $\begin{array}{c}\text { MBL codon } \\
57\end{array}$ & $\mathrm{~A} / \mathrm{G}$ & 0.01 & 0.01 & 1.08 & 0.30 & 0.47 & 0.73 & 0.11 & 2.00 \\
\hline 10 & rs1800450 & $\begin{array}{c}\text { MBL codon } \\
54\end{array}$ & $\mathrm{~A} / \mathrm{G}$ & 0.17 & 0.14 & 1.13 & 0.29 & 1.19 & 0.16 & 0.86 & 1.63 \\
\hline 10 & rs5030737 & $\begin{array}{l}\text { MBL codon } \\
52\end{array}$ & $T / C$ & 0.07 & 0.06 & 0.37 & 0.54 & 1.15 & 0.23 & 0.73 & 1.80 \\
\hline 10 & rs7095891 & $\mathrm{MBL}+4$ & $A / G$ & 0.16 & 0.23 & 7.84 & 0.01 & 0.64 & 0.16 & 0.47 & 0.88 \\
\hline 10 & rs7096206 & MBL-221 & $\mathrm{G} / \mathrm{C}$ & 0.21 & 0.21 & 0.11 & 0.74 & 0.95 & 0.15 & 0.72 & 1.27 \\
\hline 10 & rs11003125 & MBL-550 & $\mathrm{C} / \mathrm{G}$ & 0.40 & 0.36 & 2.87 & 0.09 & 1.23 & 0.12 & 0.97 & 1.56 \\
\hline 11 & rs1799963 & PGM & $\mathrm{A} / \mathrm{G}$ & 0.02 & 0.01 & 1.33 & 0.25 & 1.62 & 0.42 & 0.71 & 3.73 \\
\hline 11 & rs602128 & MMP-3 & $\mathrm{G} / \mathrm{A}$ & 0.48 & 0.49 & 0.02 & 0.89 & 0.98 & 0.12 & 0.78 & 1.24 \\
\hline 16 & rs243865 & MMP-2 & $T / C$ & 0.24 & 0.23 & 0.14 & 0.71 & 1.05 & 0.14 & 0.80 & 1.38 \\
\hline 17 & rs1137933 & $\begin{array}{c}\mathrm{iNOS}(\mathrm{NOS} 2 \mathrm{~A} \\
\text { ) }\end{array}$ & $T / C$ & 0.17 & 0.25 & 8.84 & 0.003 & 0.64 & 0.15 & 0.47 & 0.86 \\
\hline 18 & rs6098 & PAl-2_1 & $\mathrm{G} / \mathrm{A}$ & 0.21 & 0.22 & 0.29 & 0.59 & 0.92 & 0.15 & 0.69 & 1.23 \\
\hline 18 & rs6103 & PAI-2_2 & $\mathrm{G} / \mathrm{C}$ & 0.21 & 0.22 & 0.24 & 0.63 & 0.93 & 0.14 & 0.70 & 1.24 \\
\hline 19 & rs 1800469 & TGF-B1-509 & $A / G$ & 0.33 & 0.26 & 5.63 & 0.02 & 1.35 & 0.13 & 1.05 & 1.74 \\
\hline 19 & rs429358 & APO-E_1 & $C / T$ & 0.15 & 0.14 & 0.03 & 0.85 & 1.03 & 0.17 & 0.74 & 1.44 \\
\hline 19 & rs7412 & APO-E_2 & $\mathrm{T} / \mathrm{C}$ & 0.07 & 0.08 & 0.47 & 0.49 & 0.85 & 0.24 & 0.53 & 1.36 \\
\hline 20 & rs 1800576 & THBD & $\mathrm{A} / \mathrm{G}$ & $<0.005$ & 0.01 & 0.50 & 0.48 & 0.49 & 1.04 & 0.06 & 3.73 \\
\hline
\end{tabular}




\section{Chapter $5 \quad$ Mother's Genetics}

Comparison of cases and controls born between 32 and 36 weeks gestational age

Table 6 reports comparison of all maternal SNPs between cases and controls born between 32 and 36 weeks gestational age, with one SNP (MMP-2, $p=0.03$, odds ratio $2.00,95 \%$ confidence interval 1.07-3.70) showing a significant association with cerebral palsy at the $p=0.05$ level. Since this test contributed to 340 tests in the secondary aims, it was appropriate to use a Bonferroni correction to set the significance rate at 0.0001 . No SNPs were significant at this level and all odds ratios were close to unity. 


\section{Table 6}

Comparison of cases (83) and controls (55) born between 32 and 36 weeks gestational age

\begin{tabular}{|c|c|c|c|c|c|c|c|c|c|c|c|}
\hline Chromosome & SNP & Gene & $\begin{array}{l}\text { Minor allele/ } \\
\text { Major allele }\end{array}$ & $\begin{array}{l}\text { Minor allele } \\
\text { frequency in } \\
\text { cases }\end{array}$ & $\begin{array}{l}\text { Minor allele } \\
\text { frequency in } \\
\text { controls }\end{array}$ & Chi Squared value & $P$ value & $\begin{array}{l}\text { Odds } \\
\text { Ratio }\end{array}$ & $\begin{array}{l}\text { Standard } \\
\text { Error }\end{array}$ & $\begin{array}{l}\text { Lower } \\
95 \% \mathrm{CI}\end{array}$ & $\begin{array}{l}\text { Upper } \\
95 \% \mathrm{CI}\end{array}$ \\
\hline 1 & rs1801133 & MTHFR 677 & $T / C$ & 0.34 & 0.39 & 0.88 & 0.35 & 0.79 & 0.26 & 0.48 & 1.30 \\
\hline 1 & rs1801131 & MTHFR 1298 & $G / T$ & 0.32 & 0.28 & 0.44 & 0.51 & 1.20 & 0.27 & 0.70 & 2.03 \\
\hline 1 & rs6025 & $\mathrm{FVL}$ & $\mathrm{A} / \mathrm{G}$ & 0.04 & 0.02 & 0.79 & 0.38 & 2.05 & 0.83 & 0.41 & 10.35 \\
\hline 1 & rs3813946 & CR2-1 & $\mathrm{G} / \mathrm{A}$ & 0.20 & 0.21 & 0.08 & 0.78 & 0.92 & 0.31 & 0.50 & 1.67 \\
\hline 1 & rs1048971 & CR2-2 & $\mathrm{A} / \mathrm{G}$ & 0.37 & 0.36 & 0.03 & 0.87 & 1.04 & 0.26 & 0.63 & 1.72 \\
\hline 2 & rs 16944 & $\mathrm{IL} 1 \mathrm{~B}+511$ & $A / G$ & 0.31 & 0.28 & 0.34 & 0.56 & 1.17 & 0.27 & 0.69 & 2.00 \\
\hline 5 & rs 2243250 & IL-4-589 & $T / C$ & 0.13 & 0.14 & 0.06 & 0.81 & 0.92 & 0.36 & 0.45 & 1.87 \\
\hline 5 & rs1042714 & ADRB2 Q27E & $\mathrm{G} / \mathrm{C}$ & 0.44 & 0.44 & $<0.005$ & 0.96 & 1.01 & 0.25 & 0.62 & 1.65 \\
\hline 6 & rs1800629 & TNF- $\alpha 308$ & $\mathrm{~A} / \mathrm{G}$ & 0.26 & 0.19 & 1.58 & 0.21 & 1.46 & 0.30 & 0.81 & 2.63 \\
\hline 6 & rs361525 & TNF- $\alpha-238$ & $\mathrm{~A} / \mathrm{G}$ & 0.05 & 0.04 & 0.22 & 0.64 & 1.34 & 0.63 & 0.39 & 4.57 \\
\hline 6 & rs1800610 & TNF- $\alpha+488$ & $T / C$ & 0.10 & 0.12 & 0.33 & 0.56 & 0.80 & 0.40 & 0.37 & 1.73 \\
\hline 7 & rs1800795 & IL-6-174 & $\mathrm{C} / \mathrm{G}$ & 0.43 & 0.40 & 0.21 & 0.65 & 1.12 & 0.25 & 0.69 & 1.83 \\
\hline 7 & rs 16135 & NPY C4112T & $\mathrm{A} / \mathrm{G}$ & 0.04 & 0.05 & 0.01 & 0.91 & 0.94 & 0.60 & 0.29 & 3.03 \\
\hline
\end{tabular}




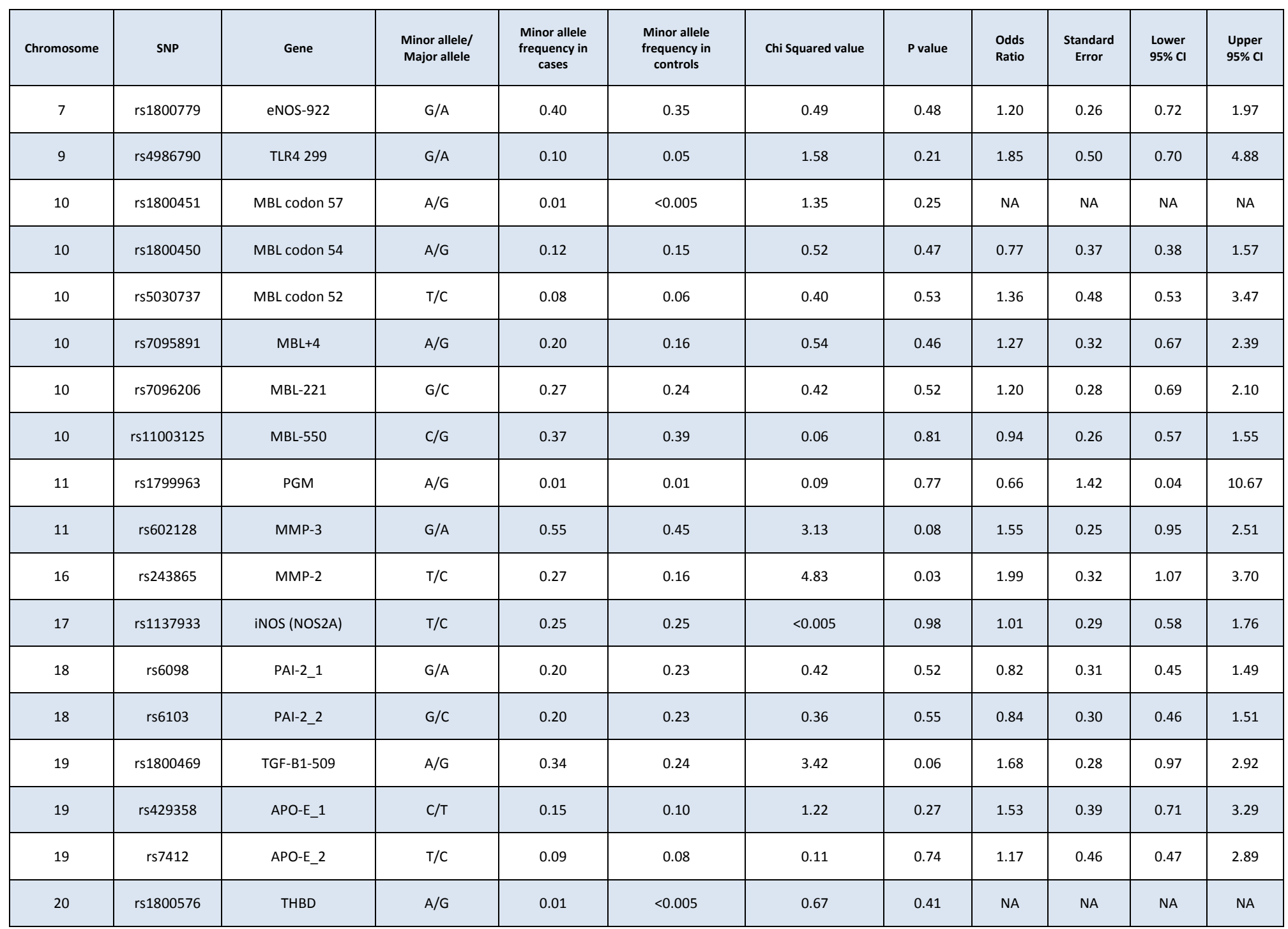




\section{Chapter 5 Mother's Genetics}

Comparison of cases born between 32 and 36 weeks gestational age and all controls

Table 7 reports comparison of all maternal SNPs between cases born between 32 and 36 weeks gestational age and all controls with two SNPs (TLR-4 $p=0.03$, odds ratio $1.84,95 \%$ confidence interval 1.11-3.18 and TGF-B-509 $p=0.03$, odds ratio $1.46,95 \%$ confidence interval 1.04-2.08) showing significant association with cerebral palsy at the $p=0.05$ level. Since this test contributed to 340 tests in the secondary aims, it was appropriate to use a Bonferroni correction to set the significance rate at 0.0001 . No SNPs were significant at this level and all odds ratios were close to unity. 
Table 7

Comparison of cases (83) born between 32 and 36 weeks gestational age and all controls (1154)

\begin{tabular}{|c|c|c|c|c|c|c|c|c|c|c|c|}
\hline Chromosome & SNP & Gene & $\begin{array}{l}\text { Minor allele/ } \\
\text { Major allele }\end{array}$ & $\begin{array}{l}\text { Minor allele } \\
\text { frequency in cases }\end{array}$ & $\begin{array}{l}\text { Minor allele frequency in } \\
\text { controls }\end{array}$ & $\begin{array}{l}\text { Chi Squared } \\
\text { value }\end{array}$ & P value & Odds Ratio & $\begin{array}{l}\text { Standard } \\
\text { Error }\end{array}$ & $\begin{array}{l}\text { Lower } \\
95 \% \mathrm{Cl}\end{array}$ & Upper 95\% Cl \\
\hline 1 & rs1801133 & MTHFR 677 & $\mathrm{~T} / \mathrm{C}$ & 0.34 & 0.34 & 0.04 & 0.84 & 0.97 & 0.17 & 0.69 & 1.35 \\
\hline 1 & rs1801131 & MTHFR 1298 & $\mathrm{G} / \mathrm{T}$ & 0.32 & 0.30 & 0.23 & 0.63 & 1.09 & 0.17 & 0.77 & 1.52 \\
\hline 1 & rs6025 & FVL & $\mathrm{A} / \mathrm{G}$ & 0.04 & 0.02 & 1.12 & 0.29 & 1.58 & 0.44 & 0.67 & 3.73 \\
\hline 1 & rs1800871 & IL-10-819 & $\mathrm{A} / \mathrm{G}$ & 0.17 & 0.23 & 2.43 & 0.12 & 0.72 & 0.21 & 0.48 & 1.09 \\
\hline 1 & rs3813946 & CR2-1 & G/A & 0.20 & 0.20 & 0.06 & 0.81 & 0.95 & 0.20 & 0.64 & 1.42 \\
\hline 1 & rs1048971 & CR2-2 & $A / G$ & 0.37 & 0.36 & 0.17 & 0.68 & 1.07 & 0.17 & 0.77 & 1.48 \\
\hline 2 & rs 16944 & $\mathrm{IL} 1 \mathrm{~B}+511$ & $A / G$ & 0.31 & 0.33 & 0.30 & 0.59 & 0.91 & 0.17 & 0.65 & 1.28 \\
\hline 4 & rs 4961 & ADD1 & $T / G$ & 0.22 & 0.20 & 0.46 & 0.50 & 1.14 & 0.20 & 0.78 & 1.68 \\
\hline 4 & rs 4073 & IL-8 & $\mathrm{A} / \mathrm{T}$ & 0.48 & 0.46 & 0.23 & 0.63 & 1.08 & 0.16 & 0.79 & 1.49 \\
\hline 5 & rs2243250 & IL-4-589 & $\mathrm{T} / \mathrm{C}$ & 0.13 & 0.14 & 0.26 & 0.61 & 0.88 & 0.24 & 0.55 & 1.42 \\
\hline 5 & rs1042714 & ADRB2 Q27E & $\mathrm{G} / \mathrm{C}$ & 0.44 & 0.44 & $<0.005$ & 0.97 & 1.01 & 0.16 & 0.73 & 1.38 \\
\hline 6 & rs1800629 & TNF- $\alpha 308$ & $\mathrm{~A} / \mathrm{G}$ & 0.26 & 0.20 & 2.54 & 0.11 & 1.35 & 0.19 & 0.93 & 1.94 \\
\hline 6 & rs 361525 & TNF- $\alpha-238$ & $\mathrm{~A} / \mathrm{G}$ & 0.05 & 0.05 & 0.01 & 0.92 & 1.04 & 0.38 & 0.50 & 2.17 \\
\hline 6 & rs 1800610 & TNF- $\alpha+488$ & $T / C$ & 0.10 & 0.09 & 0.12 & 0.73 & 1.10 & 0.27 & 0.64 & 1.87 \\
\hline 7 & rs1800795 & IL-6-174 & $\mathrm{C} / \mathrm{G}$ & 0.43 & 0.43 & $<0.005$ & 0.95 & 0.99 & 0.16 & 0.72 & 1.36 \\
\hline 7 & rs16135 & NPY C4112T & $\mathrm{A} / \mathrm{G}$ & 0.04 & 0.06 & 0.90 & 0.34 & 0.69 & 0.40 & 0.32 & 1.50 \\
\hline 7 & rs 16476 & NPY A6411C & $\mathrm{G} / \mathrm{T}$ & 0.54 & 0.48 & 1.65 & 0.20 & 1.23 & 0.16 & 0.90 & 1.69 \\
\hline
\end{tabular}




\begin{tabular}{|c|c|c|c|c|c|c|c|c|c|c|c|}
\hline Chromosome & SNP & Gene & $\begin{array}{l}\text { Minor allele/ } \\
\text { Major allele }\end{array}$ & $\begin{array}{l}\text { Minor allele } \\
\text { frequency in cases }\end{array}$ & $\begin{array}{l}\text { Minor allele frequency in } \\
\text { controls }\end{array}$ & $\begin{array}{l}\text { Chi Squared } \\
\text { value }\end{array}$ & P value & Odds Ratio & $\begin{array}{l}\text { Standard } \\
\text { Error }\end{array}$ & $\begin{array}{l}\text { Lower } \\
95 \% \mathrm{Cl}\end{array}$ & Upper $95 \% \mathrm{Cl}$ \\
\hline 7 & rs1800779 & eNOS-922 & $\mathrm{G} / \mathrm{A}$ & 0.40 & 0.38 & 0.23 & 0.63 & 1.08 & 0.17 & 0.78 & 1.50 \\
\hline 9 & rs4986790 & TLR4 299 & $\mathrm{G} / \mathrm{A}$ & 0.10 & 0.05 & 4.94 & 0.03 & 1.84 & 0.28 & 1.07 & 3.18 \\
\hline 10 & rs1800451 & $\begin{array}{l}\text { MBL codon } \\
57\end{array}$ & $A / G$ & 0.01 & 0.01 & $<0.005$ & 0.96 & 0.96 & 0.74 & 0.23 & 4.06 \\
\hline 10 & rs 1800450 & $\begin{array}{l}\text { MBL codon } \\
54\end{array}$ & $A / G$ & 0.12 & 0.14 & 0.64 & 0.42 & 0.82 & 0.25 & 0.50 & 1.34 \\
\hline 10 & rs5030737 & $\begin{array}{l}\text { MBL codon } \\
52\end{array}$ & $\mathrm{~T} / \mathrm{C}$ & 0.08 & 0.06 & 1.15 & 0.28 & 1.37 & 0.29 & 0.77 & 2.42 \\
\hline 10 & rs7095891 & $\mathrm{MBL}+4$ & $A / G$ & 0.20 & 0.23 & 0.76 & 0.38 & 0.84 & 0.20 & 0.57 & 1.24 \\
\hline 10 & rs7096206 & MBL-221 & $\mathrm{G} / \mathrm{C}$ & 0.27 & 0.21 & 2.94 & 0.09 & 1.36 & 0.18 & 0.96 & 1.95 \\
\hline 10 & rs11003125 & MBL-550 & $\mathrm{C} / \mathrm{G}$ & 0.37 & 0.36 & 0.19 & 0.67 & 1.08 & 0.17 & 0.77 & 1.49 \\
\hline 11 & rs1799963 & PGM & $A / G$ & 0.01 & 0.01 & 0.61 & 0.43 & 0.46 & 1.02 & 0.06 & 3.39 \\
\hline 11 & rs602128 & MMP-3 & $\mathrm{G} / \mathrm{A}$ & 0.55 & 0.49 & 2.89 & 0.09 & 1.32 & 0.16 & 0.96 & 1.81 \\
\hline 16 & rs243865 & MMP-2 & $T / C$ & 0.27 & 0.23 & 1.24 & 0.26 & 1.22 & 0.18 & 0.86 & 1.75 \\
\hline 17 & rs1137933 & $\begin{array}{c}\mathrm{iNOS}(\mathrm{NOS} 2 \mathrm{~A} \\
\text { ) }\end{array}$ & $\mathrm{T} / \mathrm{C}$ & 0.25 & 0.25 & $<0.005$ & 0.97 & 1.01 & 0.19 & 0.70 & 1.45 \\
\hline 18 & rs6098 & PAI-2_1 & $\mathrm{G} / \mathrm{A}$ & 0.20 & 0.22 & 0.58 & 0.45 & 0.86 & 0.20 & 0.57 & 1.28 \\
\hline 18 & rs6103 & PAI-2_2 & $\mathrm{G} / \mathrm{C}$ & 0.20 & 0.22 & 0.41 & 0.52 & 0.88 & 0.20 & 0.59 & 1.30 \\
\hline 19 & rs1800469 & TGF-B1-509 & $A / G$ & 0.34 & 0.26 & 4.84 & 0.03 & 1.46 & 0.17 & 1.04 & 2.04 \\
\hline 19 & rs429358 & APO-E_1 & $\mathrm{C} / \mathrm{T}$ & 0.15 & 0.14 & 0.01 & 0.93 & 1.02 & 0.23 & 0.65 & 1.61 \\
\hline 19 & rs7412 & APO-E_2 & $T / C$ & 0.09 & 0.08 & 0.33 & 0.56 & 1.18 & 0.29 & 0.67 & 2.09 \\
\hline 20 & rs1800576 & THBD & $A / G$ & 0.01 & 0.01 & $<0.005$ & 0.99 & 0.99 & 1.04 & 0.13 & 7.54 \\
\hline
\end{tabular}




\section{Chapter $5 \quad$ Mother's Genetics}

Comparison of cases and controls born after 36 weeks gestational age

Table 8 reports comparison of all maternal SNPs between cases and controls born after 36 weeks gestational age with one SNP (TNF- $\alpha 308 p=0.02$, odds ratio $0.76,95 \%$ confidence interval $0.60-0.96$ ) showing significant association with cerebral palsy at the $p=0.05$ level. Since this test contributed to 340 tests in the secondary aims, it was appropriate to use a Bonferroni correction to set the significance rate at 0.0001 . No SNPs were significant at this level and all odds ratios were close to unity. 
Table 8

Comparison of cases (328) and controls (1088) born after 36 weeks gestational age

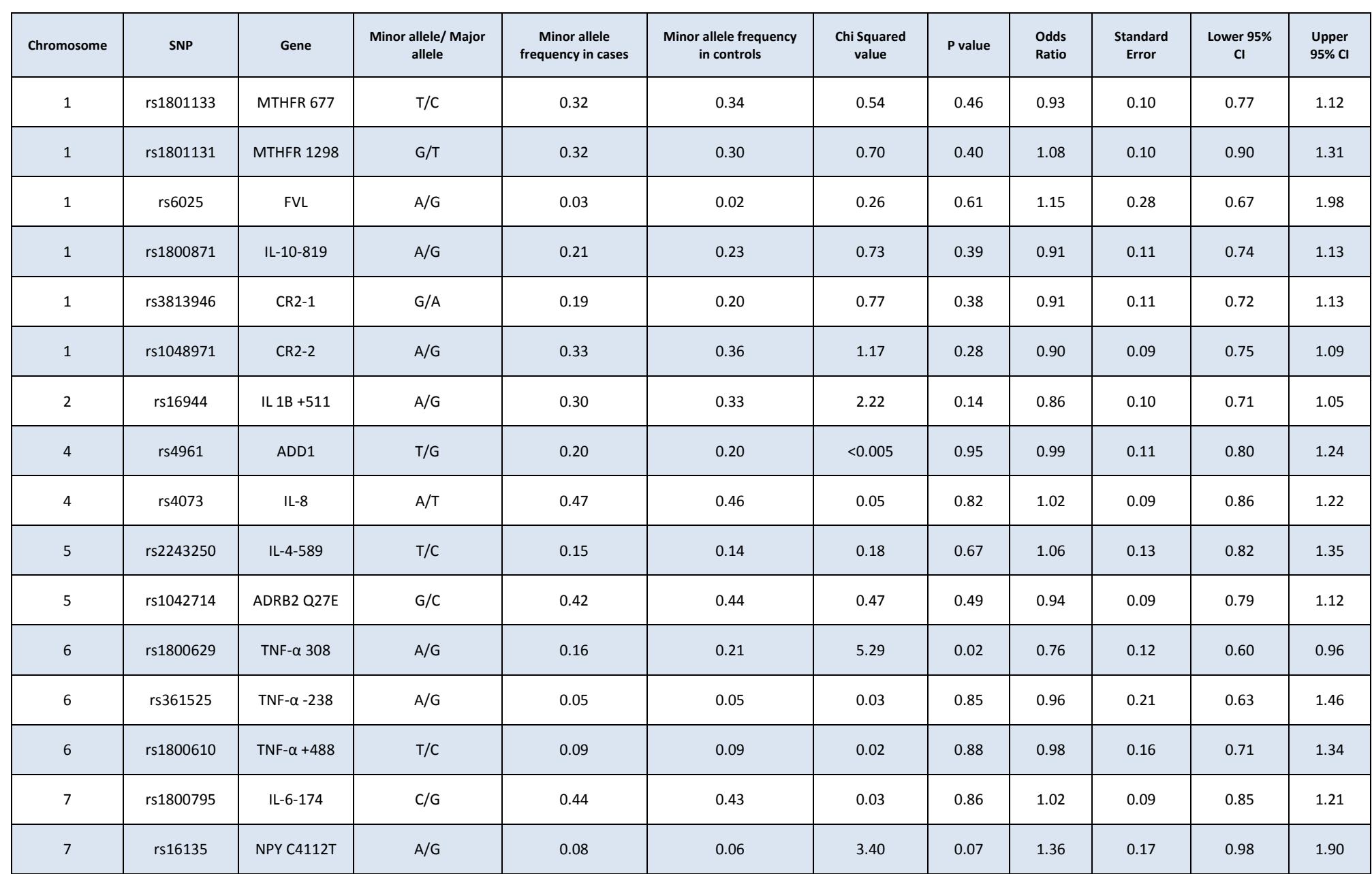




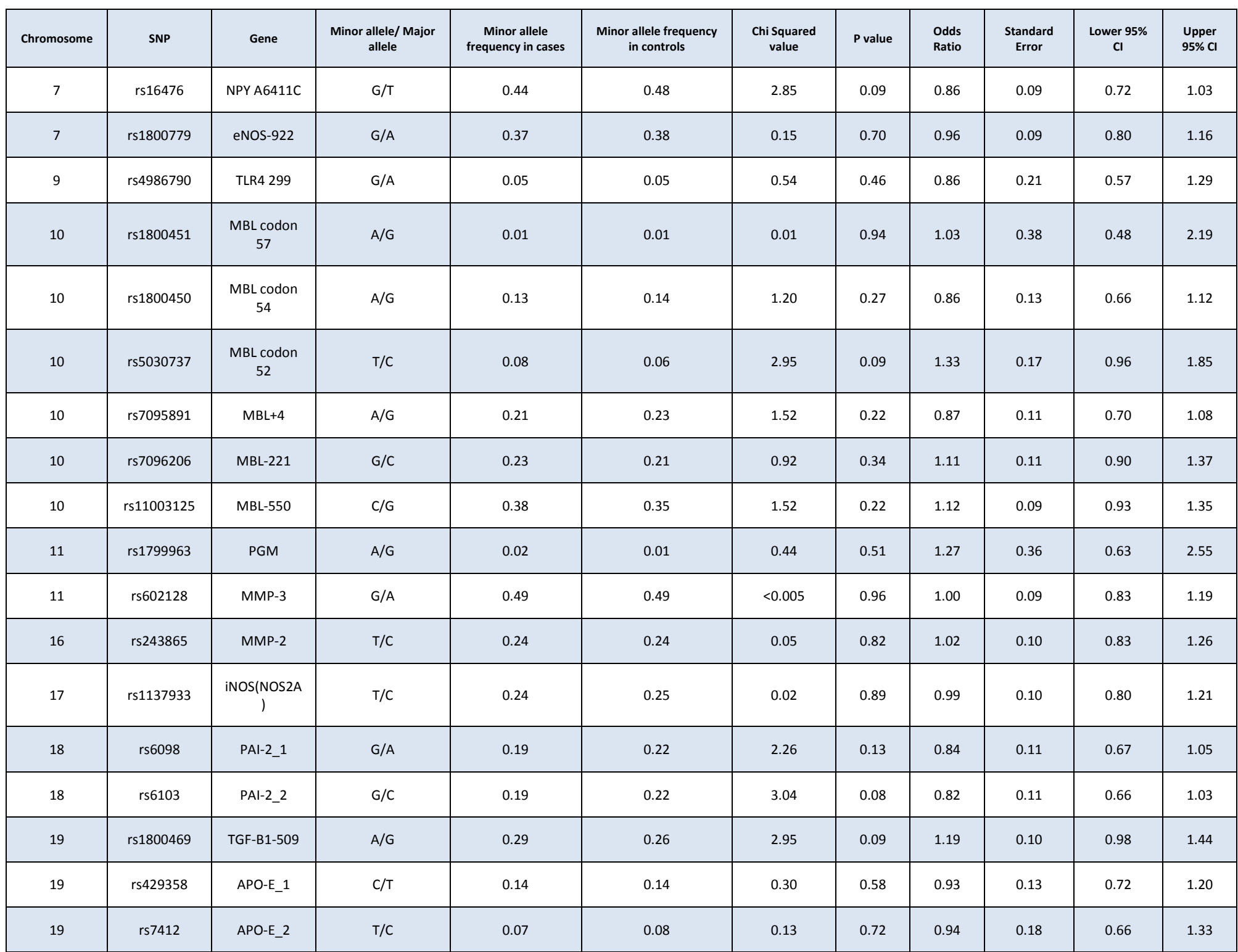




\begin{tabular}{|c|c|c|c|c|c|c|c|c|c|c|c|}
\hline Chromosome & SNP & Gene & $\begin{array}{l}\text { Minor allele/ Major } \\
\text { allele }\end{array}$ & $\begin{array}{l}\text { Minor allele } \\
\text { frequency in cases }\end{array}$ & $\begin{array}{l}\text { Minor allele frequency } \\
\text { in controls }\end{array}$ & $\begin{array}{l}\text { Chi Squared } \\
\text { value }\end{array}$ & P value & $\begin{array}{l}\text { Odds } \\
\text { Ratio }\end{array}$ & $\begin{array}{l}\text { Standard } \\
\text { Error }\end{array}$ & $\begin{array}{l}\text { Lower 95\% } \\
\quad \mathrm{Cl}\end{array}$ & $\begin{array}{l}\text { Upper } \\
95 \% \text { C }\end{array}$ \\
\hline 20 & rs1800576 & THBD & $A / G$ & $<0.005$ & 0.01 & 1.04 & 0.31 & 0.47 & 0.76 & 0.11 & 2.07 \\
\hline
\end{tabular}




\section{Chapter $5 \quad$ Mother's Genetics}

Comparison of cases born after 36 weeks gestational age and all controls

Table 9 reports comparison of all maternal SNPs between cases born after 36 weeks gestational age and all controls with one SNP (TNF- $\alpha 308 p=0.02$, odds ratio $0.77,95 \%$ confidence interval 0.61-0.97) showing a significant association with cerebral palsy at the $p=0.05$ level. Since this test contributed to 340 tests in the secondary aims, it was appropriate to use a Bonferroni correction to set the significance rate at 0.0001 . No SNPs were significant at this level and all odds ratios were close to unity. 
Table 9

Comparison of cases born after 36 weeks gestational age (328) and all controls (1154)

\begin{tabular}{|c|c|c|c|c|c|c|c|c|c|c|c|}
\hline Chromosome & SNP & Gene & $\begin{array}{l}\text { Minor allele/ } \\
\text { Major allele }\end{array}$ & $\begin{array}{l}\text { Minor allele frequency } \\
\text { in cases }\end{array}$ & $\begin{array}{l}\text { Minor allele frequency } \\
\text { in controls }\end{array}$ & $\begin{array}{l}\text { Chi Squared } \\
\text { value }\end{array}$ & P value & $\begin{array}{l}\text { Odds } \\
\text { Ratio }\end{array}$ & Standard Error & $\begin{array}{l}\text { Lower 95\% } \\
\quad \mathrm{Cl}\end{array}$ & $\begin{array}{l}\text { Upper } \\
95 \% \mathrm{Cl}\end{array}$ \\
\hline 1 & rs1801133 & MTHFR 677 & $\mathrm{~T} / \mathrm{C}$ & 0.32 & 0.34 & 0.79 & 0.38 & 0.92 & 0.09 & 0.76 & 1.11 \\
\hline 1 & rs1801131 & MTHFR 1298 & $G / T$ & 0.32 & 0.30 & 0.82 & 0.37 & 1.09 & 0.10 & 0.90 & 1.32 \\
\hline 1 & rs6025 & FVL & $\mathrm{A} / \mathrm{G}$ & 0.03 & 0.02 & 0.34 & 0.56 & 1.18 & 0.28 & 0.68 & 2.02 \\
\hline 1 & rs3813946 & CR2-1 & G/A & 0.19 & 0.20 & 0.79 & 0.37 & 0.90 & 0.11 & 0.72 & 1.13 \\
\hline 1 & rs1048971 & CR2-2 & $\mathrm{A} / \mathrm{G}$ & 0.33 & 0.36 & 1.27 & 0.26 & 0.90 & 0.09 & 0.75 & 1.08 \\
\hline 2 & rs16944 & IL 1B +511 & $\mathrm{A} / \mathrm{G}$ & 0.30 & 0.33 & 1.99 & 0.16 & 0.87 & 0.10 & 0.72 & 1.06 \\
\hline 5 & rs1042714 & ADRB2 Q27E & $\mathrm{G} / \mathrm{C}$ & 0.42 & 0.44 & 0.40 & 0.53 & 0.94 & 0.09 & 0.79 & 1.13 \\
\hline 6 & rs1800629 & TNF- $\alpha 308$ & $\mathrm{~A} / \mathrm{G}$ & 0.16 & 0.20 & 4.96 & 0.03 & 0.77 & 0.12 & 0.61 & 0.97 \\
\hline 6 & rs361525 & TNF- $\alpha-238$ & $\mathrm{~A} / \mathrm{G}$ & 0.05 & 0.05 & 0.01 & 0.94 & 0.98 & 0.21 & 0.65 & 1.49 \\
\hline 6 & rs1800610 & TNF- $\alpha+488$ & $\mathrm{~T} / \mathrm{C}$ & 0.09 & 0.09 & 0.08 & 0.78 & 0.96 & 0.16 & 0.70 & 1.31 \\
\hline 7 & rs1800795 & IL-6-174 & $\mathrm{C} / \mathrm{G}$ & 0.44 & 0.43 & 0.08 & 0.78 & 1.03 & 0.09 & 0.86 & 1.22 \\
\hline 7 & rs16135 & NPY C4112T & $A / G$ & 0.08 & 0.06 & 3.64 & 0.06 & 1.38 & 0.17 & 0.99 & 1.91 \\
\hline
\end{tabular}




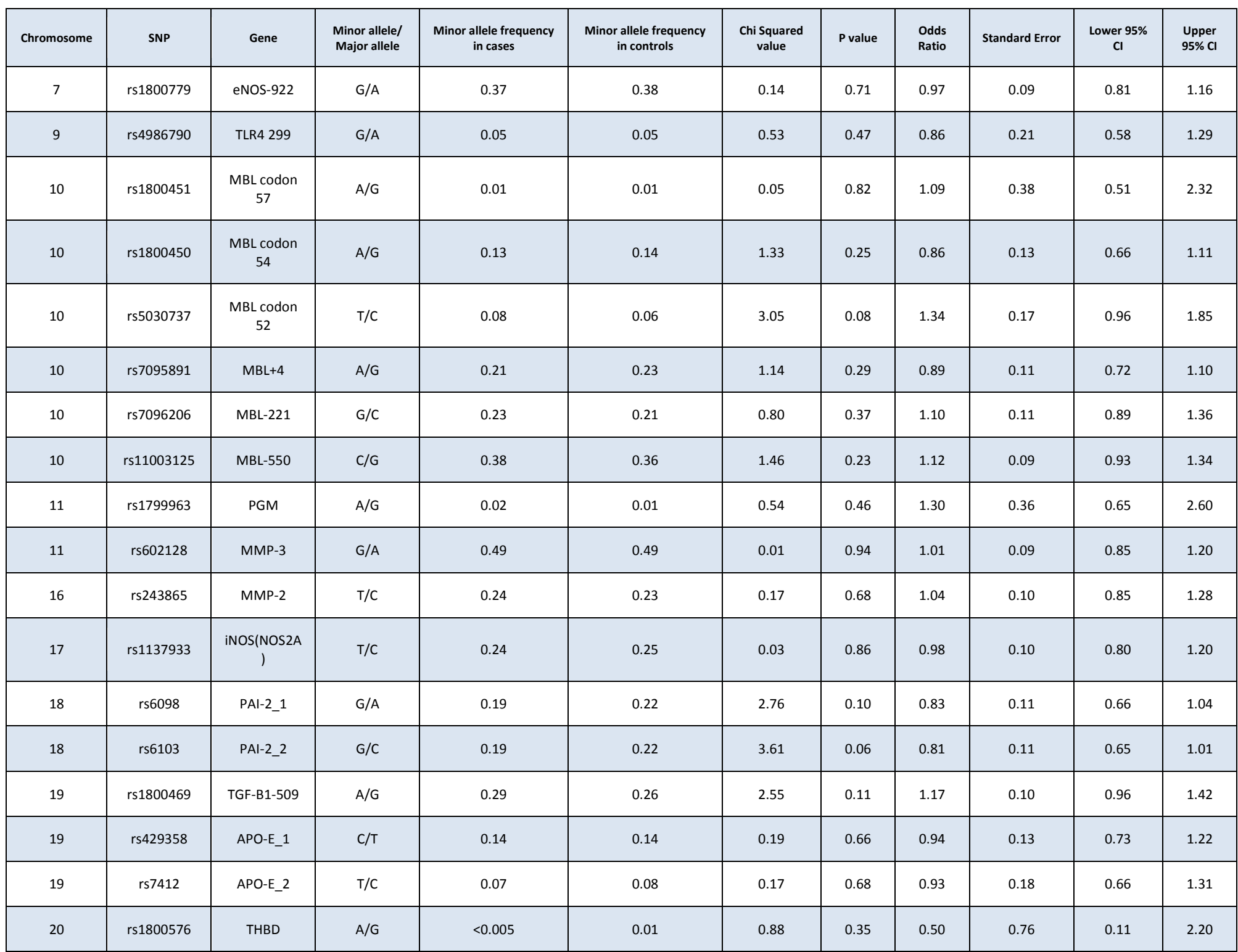




\section{Chapter $5 \quad$ Mother's Genetics}

Test of association by cerebral palsy subtype

Association between SNPs and diplegia

Table 10 reports comparison of all maternal SNPs between diplegia cases and all controls with one SNP (MBL+4 p=0.02, odds ratio $0.67,95 \%$ confidence interval 0.48-0.93) showing significant association with cerebral palsy at the $p=0.05$ level. Since this test contributed to 340 tests in the secondary aims, it was appropriate to use a Bonferroni correction to set the significance rate at 0.0001 . No SNPs were significant at this level and all odds ratios were close to unity. 


\section{Table 10}

Comparison of diplegia cases (149) and all controls (1154)

\begin{tabular}{|c|c|c|c|c|c|c|c|c|c|c|c|}
\hline Chromosome & SNP & Gene & $\begin{array}{l}\text { Minor allele/ } \\
\text { Major allele }\end{array}$ & $\begin{array}{l}\text { Minor allele frequency } \\
\text { in cases }\end{array}$ & $\begin{array}{l}\text { Minor allele frequency } \\
\text { in controls }\end{array}$ & $\begin{array}{l}\text { Chi Squared } \\
\text { value }\end{array}$ & P value & $\begin{array}{l}\text { Odds } \\
\text { Ratio }\end{array}$ & $\begin{array}{l}\text { Standard } \\
\text { Error }\end{array}$ & $\begin{array}{l}\text { Lower } \\
95 \% \mathrm{Cl}\end{array}$ & $\begin{array}{l}\text { Upper } \\
95 \% \mathrm{Cl}\end{array}$ \\
\hline 1 & rs1801133 & MTHFR 677 & $T / C$ & 0.34 & 0.34 & $<0.005$ & 0.98 & 1.00 & 0.13 & 0.77 & 1.29 \\
\hline 1 & rs1801131 & MTHFR 1298 & $\mathrm{G} / \mathrm{T}$ & 0.30 & 0.30 & 0.01 & 0.93 & 1.01 & 0.13 & 0.78 & 1.32 \\
\hline 1 & rs 6025 & $\mathrm{FVL}$ & $A / G$ & 0.03 & 0.02 & 0.54 & 0.46 & 1.31 & 0.37 & 0.64 & 2.67 \\
\hline 1 & rs3813946 & CR2-1 & $\mathrm{G} / \mathrm{A}$ & 0.21 & 0.20 & 0.03 & 0.85 & 1.03 & 0.15 & 0.76 & 1.39 \\
\hline 1 & rs1048971 & CR2-2 & $A / G$ & 0.34 & 0.36 & 0.20 & 0.66 & 0.94 & 0.13 & 0.73 & 1.22 \\
\hline 2 & rs16944 & IL 1B +511 & $A / G$ & 0.34 & 0.33 & 0.17 & 0.68 & 1.06 & 0.13 & 0.81 & 1.37 \\
\hline 5 & rs1042714 & ADRB2 Q27E & $\mathrm{G} / \mathrm{C}$ & 0.45 & 0.44 & 0.19 & 0.66 & 1.06 & 0.13 & 0.83 & 1.35 \\
\hline 6 & rs1800629 & TNF- $\alpha 308$ & $A / G$ & 0.18 & 0.20 & 0.75 & 0.39 & 0.87 & 0.16 & 0.64 & 1.19 \\
\hline 6 & rs361525 & TNF- $\alpha-238$ & $A / G$ & 0.05 & 0.05 & $<0.005$ & 0.97 & 1.01 & 0.29 & 0.57 & 1.79 \\
\hline 6 & rs1800610 & TNF- $\alpha+488$ & $T / C$ & 0.07 & 0.09 & 0.91 & 0.34 & 0.80 & 0.24 & 0.50 & 1.27 \\
\hline 7 & rs1800795 & IL-6-174 & $C / G$ & 0.37 & 0.43 & 3.38 & 0.07 & 0.79 & 0.13 & 0.62 & 1.02 \\
\hline 7 & rs16135 & NPY C4112T & $A / G$ & 0.07 & 0.06 & 0.21 & 0.65 & 1.12 & 0.25 & 0.69 & 1.82 \\
\hline
\end{tabular}




\begin{tabular}{|c|c|c|c|c|c|c|c|c|c|c|c|}
\hline Chromosome & SNP & Gene & $\begin{array}{l}\text { Minor allele/ } \\
\text { Major allele }\end{array}$ & $\begin{array}{l}\text { Minor allele frequency } \\
\text { in cases }\end{array}$ & $\begin{array}{l}\text { Minor allele frequency } \\
\text { in controls }\end{array}$ & $\begin{array}{l}\text { Chi Squared } \\
\text { value }\end{array}$ & P value & $\begin{array}{l}\text { Odds } \\
\text { Ratio }\end{array}$ & $\begin{array}{l}\text { Standard } \\
\text { Error }\end{array}$ & $\begin{array}{l}\text { Lower } \\
95 \% \mathrm{Cl}\end{array}$ & $\begin{array}{l}\text { Upper } \\
95 \% \mathrm{Cl}\end{array}$ \\
\hline 7 & rs 16476 & NPY A6411C & $\mathrm{G} / \mathrm{T}$ & 0.45 & 0.48 & 1.34 & 0.25 & 0.87 & 0.12 & 0.68 & 1.11 \\
\hline 7 & rs1800779 & eNOS-922 & $\mathrm{G} / \mathrm{A}$ & 0.39 & 0.38 & 0.20 & 0.65 & 1.06 & 0.13 & 0.83 & 1.36 \\
\hline 9 & rs 4986790 & TLR4 299 & $\mathrm{G} / \mathrm{A}$ & 0.05 & 0.05 & 0.10 & 0.75 & 0.91 & 0.28 & 0.53 & 1.58 \\
\hline 10 & rs1800450 & $\begin{array}{l}\text { MBL codon } \\
54\end{array}$ & $\mathrm{~A} / \mathrm{G}$ & 0.16 & 0.14 & 0.49 & 0.48 & 1.13 & 0.17 & 0.81 & 1.58 \\
\hline 10 & rs5030737 & $\begin{array}{l}\text { MBL codon } \\
52\end{array}$ & $\mathrm{~T} / \mathrm{C}$ & 0.08 & 0.06 & 1.85 & 0.17 & 1.36 & 0.23 & 0.87 & 2.12 \\
\hline 10 & rs11003125 & MBL-550 & $C / G$ & 0.40 & 0.36 & 1.90 & 0.17 & 1.19 & 0.13 & 0.93 & 1.53 \\
\hline 11 & rs1799963 & PGM & $\mathrm{A} / \mathrm{G}$ & 0.01 & 0.01 & $<0.005$ & 0.95 & 1.03 & 0.54 & 0.36 & 2.95 \\
\hline 11 & rs602128 & MMP-3 & $\mathrm{G} / \mathrm{A}$ & 0.51 & 0.49 & 0.80 & 0.37 & 1.12 & 0.12 & 0.88 & 1.43 \\
\hline 16 & rs243865 & MMP-2 & $\mathrm{T} / \mathrm{C}$ & 0.25 & 0.23 & 0.21 & 0.65 & 1.07 & 0.14 & 0.81 & 1.41 \\
\hline 17 & rs1137933 & $\underset{\text { inOS(NOS2A }}{\text { ) }}$ & $\mathrm{T} / \mathrm{C}$ & 0.21 & 0.25 & 2.06 & 0.15 & 0.81 & 0.15 & 0.60 & 1.08 \\
\hline 18 & rs6098 & PAI-2_1 & $\mathrm{G} / \mathrm{A}$ & 0.22 & 0.22 & 0.01 & 0.92 & 0.99 & 0.15 & 0.73 & 1.32 \\
\hline 18 & rs6103 & PAI-2_2 & $\mathrm{G} / \mathrm{C}$ & 0.22 & 0.22 & 0.01 & 0.90 & 0.98 & 0.15 & 0.73 & 1.32 \\
\hline
\end{tabular}




\begin{tabular}{|c|c|c|c|c|c|c|c|c|c|c|c|}
\hline Chromosome & SNP & Gene & $\begin{array}{l}\text { Minor allele/ } \\
\text { Major allele }\end{array}$ & $\begin{array}{l}\text { Minor allele frequency } \\
\text { in cases }\end{array}$ & $\begin{array}{l}\text { Minor allele frequency } \\
\text { in controls }\end{array}$ & $\begin{array}{l}\text { Chi Squared } \\
\text { value }\end{array}$ & P value & $\begin{array}{l}\text { Odds } \\
\text { Ratio }\end{array}$ & $\begin{array}{l}\text { Standard } \\
\text { Error }\end{array}$ & $\begin{array}{l}\text { Lower } \\
95 \% \mathrm{Cl}\end{array}$ & $\begin{array}{l}\text { Upper } \\
95 \% \mathrm{CI}\end{array}$ \\
\hline 20 & rs 1800576 & THBD & $A / G$ & $<0.005$ & 0.01 & 0.35 & 0.56 & 0.55 & 1.04 & 0.07 & 4.18 \\
\hline
\end{tabular}

$\frac{7}{2}$
음
$\frac{0}{0}$
v

3
0
0
5
0
0
0
0
0
0
0
0
0
0
0
0 


\section{Chapter 5 Mother's Genetics}

\section{Association between SNPs and hemiplegia}

Table 11 reports comparison of all maternal SNPs between hemiplegia cases and all controls with one SNP (FVL $p=0.008$, odds ratio $2.06,95 \%$ confidence interval 1.20-3.55) showing a significant association with cerebral palsy at the $p=0.05$ level. Since this test contributed to 340 tests in the secondary aims, it was appropriate to use a Bonferroni correction to set the significance rate at 0.0001 . No SNPs were significant at this level and all odds ratios were close to unity. 


\section{Table 11}

Comparison of hemiplegia cases (191) and all controls (1154)

\begin{tabular}{|c|c|c|c|c|c|c|c|c|c|c|c|}
\hline Chromosome & SNP & Gene & $\begin{array}{l}\text { Minor allele/ } \\
\text { Major allele }\end{array}$ & $\begin{array}{l}\text { Minor allele frequency } \\
\text { in cases }\end{array}$ & $\begin{array}{l}\text { Minor allele frequency } \\
\text { in controls }\end{array}$ & $\begin{array}{l}\text { Chi Squared } \\
\text { value }\end{array}$ & P value & $\begin{array}{l}\text { Odds } \\
\text { Ratio }\end{array}$ & $\begin{array}{l}\text { Standard } \\
\text { Error }\end{array}$ & $\begin{array}{l}\text { Lower } \\
95 \% \mathrm{Cl}\end{array}$ & $\begin{array}{l}\text { Upper } \\
95 \% \mathrm{Cl}\end{array}$ \\
\hline 1 & rs1801133 & MTHFR 677 & $T / C$ & 0.33 & 0.34 & 0.46 & 0.50 & 0.92 & 0.12 & 0.73 & 1.16 \\
\hline 1 & rs1801131 & MTHFR 1298 & $G / T$ & 0.31 & 0.30 & 0.04 & 0.83 & 1.03 & 0.12 & 0.81 & 1.30 \\
\hline 1 & rs6025 & FVL & $\mathrm{A} / \mathrm{G}$ & 0.05 & 0.02 & 7.05 & 0.01 & 2.06 & 0.28 & 1.20 & 3.55 \\
\hline 1 & rs3813946 & CR2-1 & $\mathrm{G} / \mathrm{A}$ & 0.19 & 0.20 & 0.24 & 0.63 & 0.93 & 0.14 & 0.71 & 1.23 \\
\hline 1 & rs1048971 & CR2-2 & $A / G$ & 0.37 & 0.36 & 0.25 & 0.62 & 1.06 & 0.11 & 0.85 & 1.33 \\
\hline 2 & rs16944 & IL 1B +511 & $A / G$ & 0.29 & 0.33 & 2.13 & 0.14 & 0.84 & 0.12 & 0.66 & 1.06 \\
\hline 5 & rs1042714 & ADRB2 Q27E & $\mathrm{G} / \mathrm{C}$ & 0.46 & 0.44 & 0.66 & 0.42 & 1.10 & 0.11 & 0.88 & 1.36 \\
\hline 6 & rs1800629 & TNF- $\alpha 308$ & $\mathrm{~A} / \mathrm{G}$ & 0.17 & 0.20 & 2.43 & 0.12 & 0.80 & 0.15 & 0.60 & 1.06 \\
\hline 6 & rs361525 & TNF- $\alpha-238$ & $A / G$ & 0.03 & 0.05 & 2.44 & 0.12 & 0.61 & 0.32 & 0.32 & 1.14 \\
\hline 6 & rs1800610 & TNF- $\alpha+488$ & $T / C$ & 0.08 & 0.09 & 0.20 & 0.65 & 0.91 & 0.20 & 0.62 & 1.36 \\
\hline 7 & rs1800795 & IL-6-174 & $\mathrm{C} / \mathrm{G}$ & 0.47 & 0.43 & 2.19 & 0.14 & 1.18 & 0.11 & 0.95 & 1.47 \\
\hline 7 & rs16135 & NPY C4112T & $A / G$ & 0.07 & 0.06 & 0.92 & 0.34 & 1.23 & 0.21 & 0.81 & 1.87 \\
\hline
\end{tabular}




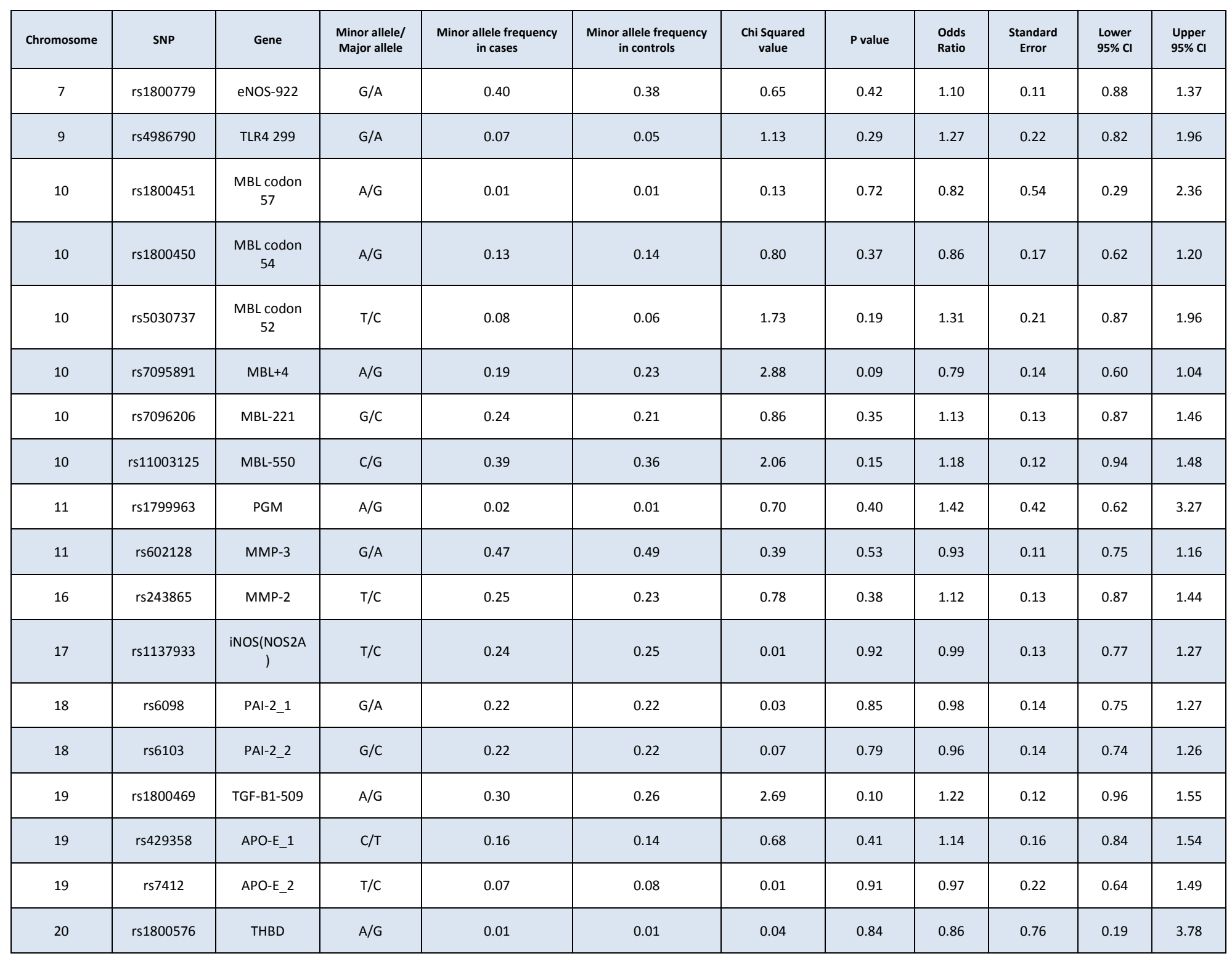




\section{Chapter $5 \quad$ Mother's Genetics}

Association between SNPs and quadriplegia

Table 12 reports comparison of all maternal SNPs between quadriplegia cases and all controls with one SNP (PAl-2_2 $p=0.04$, odds ratio $0.71,95 \%$ confidence interval $0.51-0.98$ ) showing a significant association with cerebral palsy at the $p=0.05$ level. Since this test contributed to 340 tests in the secondary aims, it was appropriate to use a Bonferroni correction to set the significance rate at 0.0001 . No SNPs were significant at this level and all odds ratios were close to unity. 


\section{Table 12}

Comparison of quadriplegia cases (145) and all controls (1154)

\begin{tabular}{|c|c|c|c|c|c|c|c|c|c|c|c|}
\hline Chromosome & SNP & Gene & $\begin{array}{l}\text { Minor allele/ } \\
\text { Major allele }\end{array}$ & $\begin{array}{l}\text { Minor allele frequency } \\
\text { in cases }\end{array}$ & $\begin{array}{l}\text { Minor allele frequency } \\
\text { in controls }\end{array}$ & $\begin{array}{l}\text { Chi Squared } \\
\text { value }\end{array}$ & P value & $\begin{array}{l}\text { Odds } \\
\text { Ratio }\end{array}$ & $\begin{array}{l}\text { Standard } \\
\text { Error }\end{array}$ & $\begin{array}{l}\text { Lower } \\
95 \% \mathrm{Cl}\end{array}$ & $\begin{array}{l}\text { Upper } \\
95 \% \mathrm{CI}\end{array}$ \\
\hline 1 & rs 1801133 & MTHFR 677 & $T / C$ & 0.38 & 0.34 & 1.77 & 0.18 & 1.19 & 0.13 & 0.92 & 1.53 \\
\hline 1 & rs1801131 & MTHFR 1298 & $\mathrm{G} / \mathrm{T}$ & 0.32 & 0.30 & 0.30 & 0.58 & 1.08 & 0.13 & 0.83 & 1.40 \\
\hline 1 & rs6025 & $\mathrm{FVL}$ & $A / G$ & 0.04 & 0.02 & 3.34 & 0.07 & 1.80 & 0.33 & 0.95 & 3.40 \\
\hline 1 & rs3813946 & CR2-1 & G/A & 0.20 & 0.20 & 0.06 & 0.80 & 0.96 & 0.16 & 0.71 & 1.31 \\
\hline 1 & rs1048971 & CR2-2 & $A / G$ & 0.34 & 0.36 & 0.25 & 0.61 & 0.94 & 0.13 & 0.72 & 1.21 \\
\hline 2 & rs16944 & $\mathrm{IL} 1 \mathrm{~B}+511$ & $\mathrm{~A} / \mathrm{G}$ & 0.30 & 0.33 & 1.37 & 0.24 & 0.85 & 0.14 & 0.65 & 1.11 \\
\hline 5 & rs 1042714 & ADRB2 Q27E & $\mathrm{G} / \mathrm{C}$ & 0.44 & 0.44 & 0.01 & 0.93 & 1.01 & 0.13 & 0.79 & 1.30 \\
\hline 6 & rs1800629 & TNF- $\alpha 308$ & $A / G$ & 0.17 & 0.20 & 1.55 & 0.21 & 0.81 & 0.17 & 0.59 & 1.13 \\
\hline 6 & rs361525 & TNF- $\alpha-238$ & $A / G$ & 0.06 & 0.05 & 0.83 & 0.36 & 1.28 & 0.27 & 0.75 & 2.16 \\
\hline 6 & rs 1800610 & TNF- $\alpha+488$ & $T / C$ & 0.11 & 0.09 & 1.76 & 0.18 & 1.31 & 0.20 & 0.88 & 1.94 \\
\hline 7 & rs 1800795 & IL-6-174 & $\mathrm{C} / \mathrm{G}$ & 0.40 & 0.43 & 1.30 & 0.25 & 0.86 & 0.13 & 0.67 & 1.11 \\
\hline 7 & rs16135 & NPY C4112T & $A / G$ & 0.06 & 0.06 & 0.01 & 0.93 & 0.98 & 0.26 & 0.58 & 1.64 \\
\hline
\end{tabular}




\begin{tabular}{|c|c|c|c|c|c|c|c|c|c|c|c|}
\hline Chromosome & SNP & Gene & $\begin{array}{l}\text { Minor allele/ } \\
\text { Major allele }\end{array}$ & $\begin{array}{l}\text { Minor allele frequency } \\
\text { in cases }\end{array}$ & $\begin{array}{l}\text { Minor allele frequency } \\
\text { in controls }\end{array}$ & $\begin{array}{l}\text { Chi Squared } \\
\text { value }\end{array}$ & P value & $\begin{array}{l}\text { Odds } \\
\text { Ratio }\end{array}$ & $\begin{array}{c}\text { Standard } \\
\text { Error }\end{array}$ & $\begin{array}{l}\text { Lower } \\
95 \% \mathrm{Cl}\end{array}$ & $\begin{array}{l}\text { Upper } \\
95 \% \mathrm{CI}\end{array}$ \\
\hline 7 & rs16476 & NPY A6411C & $G / T$ & 0.53 & 0.48 & 2.24 & 0.13 & 1.21 & 0.13 & 0.94 & 1.55 \\
\hline 7 & rs1800779 & eNOS-922 & $\mathrm{G} / \mathrm{A}$ & 0.40 & 0.38 & 0.33 & 0.57 & 1.08 & 0.13 & 0.84 & 1.38 \\
\hline 9 & rs4986790 & TLR4 299 & $\mathrm{G} / \mathrm{A}$ & 0.04 & 0.05 & 0.87 & 0.35 & 0.75 & 0.31 & 0.41 & 1.37 \\
\hline 10 & rs1800450 & $\begin{array}{l}\text { MBL codon } \\
54\end{array}$ & $\mathrm{~A} / \mathrm{G}$ & 0.14 & 0.14 & 0.07 & 0.79 & 0.95 & 0.18 & 0.67 & 1.36 \\
\hline 10 & rs5030737 & $\begin{array}{l}\text { MBL codon } \\
52\end{array}$ & $\mathrm{~T} / \mathrm{C}$ & 0.07 & 0.06 & 0.02 & 0.88 & 1.04 & 0.25 & 0.63 & 1.71 \\
\hline 10 & rs11003125 & MBL-550 & $\mathrm{C} / \mathrm{G}$ & 0.38 & 0.36 & 0.42 & 0.52 & 1.09 & 0.13 & 0.84 & 1.41 \\
\hline 11 & rs1799963 & PGM & $\mathrm{A} / \mathrm{G}$ & 0.01 & 0.01 & 0.01 & 0.91 & 1.06 & 0.54 & 0.37 & 3.03 \\
\hline 11 & rs602128 & MMP-3 & $\mathrm{G} / \mathrm{A}$ & 0.51 & 0.49 & 0.80 & 0.37 & 1.12 & 0.13 & 0.87 & 1.43 \\
\hline 16 & rs 243865 & MMP-2 & $T / C$ & 0.25 & 0.23 & 0.50 & 0.48 & 1.11 & 0.14 & 0.83 & 1.47 \\
\hline 17 & rs1137933 & $\begin{array}{c}\text { iNOS(NOS2A } \\
\text { ) }\end{array}$ & $T / C$ & 0.20 & 0.25 & 2.53 & 0.11 & 0.78 & 0.15 & 0.58 & 1.06 \\
\hline 18 & rs6098 & PAI-2_1 & $\mathrm{G} / \mathrm{A}$ & 0.18 & 0.22 & 3.09 & 0.08 & 0.75 & 0.16 & 0.54 & 1.03 \\
\hline 18 & rs6103 & PAI-2_2 & $\mathrm{G} / \mathrm{C}$ & 0.17 & 0.22 & 4.29 & 0.04 & 0.71 & 0.17 & 0.51 & 0.98 \\
\hline
\end{tabular}




\begin{tabular}{|c|c|c|c|c|c|c|c|c|c|c|c|}
\hline Chromosome & SNP & Gene & $\begin{array}{l}\text { Minor allele/ } \\
\text { Major allele }\end{array}$ & $\begin{array}{l}\text { Minor allele frequency } \\
\text { in cases }\end{array}$ & $\begin{array}{l}\text { Minor allele frequency } \\
\text { in controls }\end{array}$ & $\begin{array}{l}\text { Chi Squared } \\
\text { value }\end{array}$ & P value & $\begin{array}{l}\text { Odds } \\
\text { Ratio }\end{array}$ & $\begin{array}{l}\text { Standard } \\
\text { Error }\end{array}$ & $\begin{array}{l}\text { Lower } \\
95 \% \mathrm{Cl}\end{array}$ & $\begin{array}{l}\text { Upper } \\
95 \% \mathrm{C}\end{array}$ \\
\hline 20 & rs1800576 & THBD & $\mathrm{A} / \mathrm{G}$ & $<0.005$ & 0.01 & 0.31 & 0.58 & 0.57 & 1.04 & 0.07 & 4.32 \\
\hline
\end{tabular}




\section{Chapter $5 \quad$ Mother's Genetics}

Association between SNPs and other cerebral palsy types

Table 13 reports comparison of all maternal SNPs between cases born before 32 weeks gestational age and all controls with two SNPs ( IL-10-819 p=0.03 odds ratio $0.60,95 \%$ confidence interval $0.37-0.97$ and NPY C4112T $p=0.01$ odds ratio $2.00,95 \%$ confidence interval $1.15-3.45$ ) showing significant association with cerebral palsy at the $p=0.05$ level. Since this test contributed to 340 tests in the secondary aims, it was appropriate to use a Bonferroni correction to set the significance rate at 0.0001 . No SNPs were significant at this level and all odds ratios were close to unity. 


\section{Table 13}

Comparison of other cerebral palsy types (70) and all controls (1154)

\begin{tabular}{|c|c|c|c|c|c|c|c|c|c|c|c|}
\hline Chromosome & SNP & Gene & $\begin{array}{l}\text { Minor allele/ } \\
\text { Major allele }\end{array}$ & $\begin{array}{l}\text { Minor allele frequency } \\
\text { in cases }\end{array}$ & $\begin{array}{l}\text { Minor allele frequency } \\
\text { in controls }\end{array}$ & $\begin{array}{l}\text { Chi Squared } \\
\text { value }\end{array}$ & Pvalue & Odds Ratio & $\begin{array}{l}\text { Standard } \\
\text { Error }\end{array}$ & $\begin{array}{l}\text { Lower } \\
95 \% \mathrm{Cl}\end{array}$ & $\begin{array}{l}\text { Upper } \\
95 \% \mathrm{Cl}\end{array}$ \\
\hline 1 & rs1801133 & MTHFR 677 & $T / C$ & 0.26 & 0.34 & 3.68 & 0.06 & 0.69 & 0.20 & 0.47 & 1.01 \\
\hline 1 & rs1801131 & MTHFR 1298 & $\mathrm{G} / \mathrm{T}$ & 0.33 & 0.30 & 0.37 & 0.54 & 1.12 & 0.19 & 0.78 & 1.62 \\
\hline 1 & rs6025 & $\mathrm{FVL}$ & $\mathrm{A} / \mathrm{G}$ & 0.01 & 0.02 & 0.49 & 0.48 & 0.60 & 0.73 & 0.15 & 2.50 \\
\hline 1 & rs 1800871 & IL-10-819 & $A / G$ & 0.15 & 0.23 & 4.50 & 0.03 & 0.60 & 0.24 & 0.37 & 0.97 \\
\hline 1 & rs3813946 & CR2-1 & $\mathrm{G} / \mathrm{A}$ & 0.19 & 0.20 & 0.08 & 0.77 & 0.94 & 0.22 & 0.61 & 1.45 \\
\hline 1 & rs1048971 & CR2-2 & $A / G$ & 0.33 & 0.36 & 0.34 & 0.56 & 0.90 & 0.19 & 0.62 & 1.29 \\
\hline 2 & rs16944 & IL 1B +511 & $A / G$ & 0.26 & 0.33 & 2.85 & 0.09 & 0.71 & 0.20 & 0.48 & 1.06 \\
\hline 4 & rs4961 & ADD1 & $T / G$ & 0.17 & 0.20 & 0.47 & 0.49 & 0.85 & 0.23 & 0.54 & 1.34 \\
\hline 4 & $\mathrm{rs} 4073$ & IL-8 & $\mathrm{A} / \mathrm{T}$ & 0.49 & 0.46 & 0.49 & 0.48 & 1.13 & 0.18 & 0.80 & 1.59 \\
\hline 5 & rs2243250 & IL-4-589 & $T / C$ & 0.12 & 0.14 & 0.34 & 0.56 & 0.86 & 0.27 & 0.51 & 1.44 \\
\hline 5 & rs1042714 & ADRB2 Q27E & $\mathrm{G} / \mathrm{C}$ & 0.41 & 0.44 & 0.55 & 0.46 & 0.88 & 0.18 & 0.62 & 1.24 \\
\hline 6 & rs 1800629 & TNF- $\alpha 308$ & $A / G$ & 0.19 & 0.20 & 0.27 & 0.60 & 0.89 & 0.22 & 0.57 & 1.38 \\
\hline 6 & rs361525 & TNF- $\alpha-238$ & $A / G$ & 0.05 & 0.05 & 0.04 & 0.85 & 1.08 & 0.40 & 0.49 & 2.37 \\
\hline 6 & rs1800610 & TNF- $\alpha+488$ & $T / C$ & 0.10 & 0.09 & 0.21 & 0.65 & 1.14 & 0.29 & 0.65 & 2.02 \\
\hline 7 & rs1800795 & IL-6-174 & $C / G$ & 0.41 & 0.43 & 0.16 & 0.69 & 0.93 & 0.18 & 0.66 & 1.32 \\
\hline 7 & rs16135 & NPY C4112T & $A / G$ & 0.11 & 0.06 & 6.31 & 0.01 & 1.99 & 0.28 & 1.15 & 3.45 \\
\hline 7 & rs16476 & NPY A6411C & $\mathrm{G} / \mathrm{T}$ & 0.46 & 0.48 & 0.41 & 0.52 & 0.89 & 0.18 & 0.63 & 1.26 \\
\hline
\end{tabular}




\begin{tabular}{|c|c|c|c|c|c|c|c|c|c|c|c|}
\hline Chromosome & SNP & Gene & $\begin{array}{l}\text { Minor allele/ } \\
\text { Major allele }\end{array}$ & $\begin{array}{l}\text { Minor allele frequency } \\
\text { in cases }\end{array}$ & $\begin{array}{l}\text { Minor allele frequency } \\
\text { in controls }\end{array}$ & $\begin{array}{l}\text { Chi Squared } \\
\text { value }\end{array}$ & P value & Odds Ratio & $\begin{array}{l}\text { Standard } \\
\text { Error }\end{array}$ & $\begin{array}{l}\text { Lower } \\
95 \% \mathrm{CI}\end{array}$ & $\begin{array}{l}\text { Upper } \\
95 \% \mathrm{CI}\end{array}$ \\
\hline 7 & rs1800779 & eNOS-922 & G/A & 0.35 & 0.38 & 0.50 & 0.48 & 0.88 & 0.18 & 0.61 & 1.26 \\
\hline 9 & rs4986790 & TLR4 299 & G/A & 0.06 & 0.05 & 0.23 & 0.63 & 1.19 & 0.36 & 0.59 & 2.38 \\
\hline 10 & rs1800451 & $\begin{array}{l}\text { MBL codon } \\
57\end{array}$ & $A / G$ & 0.01 & 0.01 & 0.33 & 0.56 & 0.56 & 1.02 & 0.08 & 4.14 \\
\hline 10 & rs1800450 & $\begin{array}{l}\text { MBL codon } \\
54\end{array}$ & $\mathrm{~A} / \mathrm{G}$ & 0.10 & 0.14 & 2.03 & 0.15 & 0.66 & 0.29 & 0.38 & 1.17 \\
\hline 10 & rs5030737 & $\begin{array}{l}\text { MBL codon } \\
52\end{array}$ & $T / C$ & 0.09 & 0.06 & 1.92 & 0.17 & 1.52 & 0.30 & 0.84 & 2.75 \\
\hline 10 & rs7095891 & $M B L+4$ & $\mathrm{~A} / \mathrm{G}$ & 0.25 & 0.23 & 0.24 & 0.62 & 1.11 & 0.20 & 0.74 & 1.65 \\
\hline 10 & rs7096206 & MBL-221 & $\mathrm{G} / \mathrm{C}$ & 0.24 & 0.21 & 0.48 & 0.49 & 1.15 & 0.21 & 0.77 & 1.73 \\
\hline 10 & rs11003125 & MBL-550 & $C / G$ & 0.40 & 0.36 & 0.89 & 0.34 & 1.19 & 0.18 & 0.83 & 1.70 \\
\hline 11 & rs1799963 & PGM & $A / G$ & 0.02 & 0.01 & 0.70 & 0.40 & 1.66 & 0.61 & 0.50 & 5.51 \\
\hline 11 & rs602128 & MMP-3 & G/A & 0.48 & 0.49 & 0.03 & 0.86 & 0.97 & 0.18 & 0.69 & 1.37 \\
\hline 16 & rs243865 & MMP-2 & $T / C$ & 0.25 & 0.23 & 0.13 & 0.72 & 1.08 & 0.20 & 0.72 & 1.60 \\
\hline 17 & rs1137933 & iNOS(NOS2A & $T / C$ & 0.23 & 0.25 & 0.14 & 0.71 & 0.93 & 0.21 & 0.62 & 1.39 \\
\hline 18 & rs6098 & PAl-2_1 & G/A & 0.17 & 0.22 & 2.19 & 0.14 & 0.71 & 0.23 & 0.45 & 1.12 \\
\hline 18 & rs6103 & PAl-2_2 & $\mathrm{G} / \mathrm{C}$ & 0.17 & 0.22 & 2.39 & 0.12 & 0.70 & 0.23 & 0.44 & 1.10 \\
\hline 19 & rs1800469 & TGF-B1-509 & $\mathrm{A} / \mathrm{G}$ & 0.31 & 0.26 & 1.60 & 0.21 & 1.27 & 0.19 & 0.88 & 1.84 \\
\hline 19 & rs 429358 & APO-E_1 & $\mathrm{C} / \mathrm{T}$ & 0.13 & 0.14 & 0.17 & 0.68 & 0.90 & 0.26 & 0.54 & 1.50 \\
\hline 19 & rs7412 & APO-E_2 & $T / C$ & 0.08 & 0.08 & 0.01 & 0.93 & 1.03 & 0.34 & 0.53 & 2.00 \\
\hline 20 & rs 1800576 & THBD & $\mathrm{A} / \mathrm{G}$ & $<0.005$ & 0.01 & 0.86 & 0.35 & 0.00 & $\inf$ & 0.00 & nan \\
\hline
\end{tabular}




\section{Chapter 5 Mother's Genetics}

\section{Association with APOE genotypes}

Table 14 reports comparison of all maternal APOE genotypes between cases and controls, comparing to the E3/E3 genotype. Only one genotype showed a significant association with cerebral palsy at the $p<0.05$ level (E3/E4 in diplegia with reported infection $p=0.02$, odds ratio $1.91,95 \%$ confidence interval $1.10-3.33)$. Since these tests contributed to 80 tests of APOE association with cerebral palsy, it was appropriate to use a Bonferroni correction to set the significance rate at 0.0006 . No associations were significant at this level and most odds ratios approached unity. 


\section{Table 14}

Association of maternal APOE genotypes between cases and controls

\begin{tabular}{|c|c|c|c|c|c|c|c|c|c|}
\hline APOE Comparison & Test genotype & $\begin{array}{l}\text { Frequency of test } \\
\text { genotype in cases }\end{array}$ & $\begin{array}{l}\text { Frequency of test } \\
\text { genotype in controls }\end{array}$ & $\begin{array}{l}\text { Comparison } \\
\text { genotype }\end{array}$ & $\begin{array}{l}\text { Chi Squared } \\
\text { value }\end{array}$ & $\begin{array}{l}\text { Pvalue } \\
\text { (Fischer's } \\
\text { exact) }\end{array}$ & Odds Ratio & Lower $95 \% \mathrm{Cl}$ & Upper $95 \% \mathrm{CI}$ \\
\hline All cases vs controls & E4/E4 & 0.03 & 0.03 & E3/E3 & 0.06 & 0.81 & 0.91 & 0.43 & 1.95 \\
\hline All cases vs controls & E3/E4 & 0.28 & 0.27 & E3/E3 & 0.02 & 0.89 & 1.02 & 0.79 & 1.31 \\
\hline All cases vs controls & E2/E4 & 0.03 & 0.04 & E3/E3 & 0.52 & 0.47 & 0.75 & 0.35 & 1.63 \\
\hline All cases vs controls & E2/E3 & 0.15 & 0.17 & E3/E3 & 0.49 & 0.48 & 0.89 & 0.63 & 1.24 \\
\hline All cases vs controls & E2/E2 & 0.01 & 0.01 & E3/E3 & $<0.005$ & $(1.00)$ & 1.00 & 0.25 & 4.03 \\
\hline Hemiplegia vs controls & E4/E4 & 0.04 & 0.03 & E3/E3 & 0.08 & $(0.77)$ & 1.17 & 0.40 & 3.48 \\
\hline Hemiplegia vs controls & $\mathrm{E} 3 / \mathrm{E} 4$ & 0.30 & 0.27 & E3/E3 & 0.43 & 0.51 & 1.14 & 0.78 & 1.67 \\
\hline Hemiplegia vs controls & E2/E4 & 0.05 & 0.04 & E3/E3 & 0.35 & $(0.58)$ & 1.35 & 0.50 & 3.60 \\
\hline Hemiplegia vs controls & E2/E3 & 0.13 & 0.17 & E3/E3 & 0.70 & 0.40 & 0.79 & 0.45 & 1.38 \\
\hline Hemiplegia vs controls & E2/E2 & 0.02 & 0.01 & E3/E3 & 0.91 & $(0.30)$ & 2.15 & 0.43 & 10.81 \\
\hline Diplegia vs controls & E4/E4 & 0.03 & 0.03 & E3/E3 & 0.12 & $(1.00)$ & 0.78 & 0.18 & 3.36 \\
\hline Diplegia vs controls & E3/E4 & 0.33 & 0.27 & E3/E3 & 1.86 & 0.17 & 1.33 & 0.88 & 2.01 \\
\hline Diplegia vs controls & E2/E4 & 0.03 & 0.04 & E3/E3 & 0.21 & $(1.00)$ & 0.71 & 0.17 & 3.06 \\
\hline Diplegia vs controls & E2/E3 & 0.20 & 0.17 & E3/E3 & 0.97 & 0.33 & 1.30 & 0.77 & 2.20 \\
\hline Diplegia vs controls & E2/E2 & $<0.005$ & 0.01 & E3/E3 & - & - & - & - & - \\
\hline Quadriplegia vs controls & E4/E4 & 0.03 & 0.03 & E3/E3 & $<0.005$ & $(1.00)$ & 0.98 & 0.29 & 3.32 \\
\hline
\end{tabular}




\begin{tabular}{|c|c|c|c|c|c|c|c|c|c|}
\hline APOE Comparison & Test genotype & $\begin{array}{l}\text { Frequency of test } \\
\text { genotype in cases }\end{array}$ & $\begin{array}{l}\text { Frequency of test } \\
\text { genotype in controls }\end{array}$ & $\begin{array}{c}\text { Comparison } \\
\text { genotype }\end{array}$ & $\begin{array}{l}\text { Chi Squared } \\
\text { value }\end{array}$ & $\begin{array}{c}\text { P value } \\
\text { (Fischer's } \\
\text { exact) }\end{array}$ & Odds Ratio & Lower $95 \% \mathrm{Cl}$ & Upper $95 \% \mathrm{Cl}$ \\
\hline Quadriplegia vs controls & E3/E4 & 0.19 & 0.27 & E3/E3 & 3.53 & 0.06 & 0.63 & 0.39 & 1.02 \\
\hline Quadriplegia vs controls & E2/E4 & 0.01 & 0.04 & E3/E3 & 1.57 & $(0.35)$ & 0.30 & 0.04 & 2.23 \\
\hline Quadriplegia vs controls & E2/E3 & 0.11 & 0.17 & E3/E3 & 1.76 & 0.19 & 0.66 & 0.35 & 1.23 \\
\hline Quadriplegia vs controls & E2/E2 & 0.01 & 0.01 & E3/E3 & 0.03 & $(0.60)$ & 1.19 & 0.14 & 10.01 \\
\hline Other CP types vs controls & E4/E4 & $<0.005$ & 0.03 & E3/E3 & - & - & - & - & - \\
\hline Other $\mathrm{CP}$ types vs controls & E3/E4 & 0.30 & 0.27 & E3/E3 & 0.21 & 0.65 & 1.15 & 0.63 & 2.11 \\
\hline Other CP types vs controls & E2/E4 & 0.03 & 0.04 & E3/E3 & 0.08 & $(1.00)$ & 0.75 & 0.10 & 5.69 \\
\hline Other CP types vs controls & E2/E3 & 0.20 & 0.17 & E3/E3 & 0.30 & 0.58 & 1.24 & 0.58 & 2.62 \\
\hline Other CP types vs controls & E2/E2 & $<0.005$ & 0.01 & E3/E3 & 0.33 & $(1.00)$ & 1.01 & 1.00 & 1.02 \\
\hline$<32$ weeks $G A$ vs controls & E4/E4 & 0.02 & 0.03 & E3/E3 & 0.21 & $(1.00)$ & 0.71 & 0.16 & 3.08 \\
\hline$<32$ weeks GA vs controls & E3/E4 & 0.29 & 0.27 & E3/E3 & 0.18 & 0.67 & 1.10 & 0.72 & 1.67 \\
\hline$<32$ weeks $G A$ vs controls & E2/E4 & 0.02 & 0.04 & E3/E3 & 0.34 & 0.56 & 0.65 & 0.15 & 2.81 \\
\hline$<32$ weeks $G A$ vs controls & E2/E3 & 0.16 & 0.17 & E3/E3 & 0.03 & 0.88 & 0.96 & 0.54 & 1.68 \\
\hline$<32$ weeks $G A$ vs controls & E2/E2 & $<0.005$ & 0.01 & E3/E3 & - & - & - & - & - \\
\hline $\begin{array}{l}\text { 32-36 weeks GA vs } \\
\text { controls }\end{array}$ & E4/E4 & $<0.005$ & 0.03 & E3/E3 & - & - & & - & - \\
\hline $\begin{array}{l}\text { 32-36 weeks GA vs } \\
\text { controls }\end{array}$ & E3/E4 & 0.31 & 0.27 & E3/E3 & 0.28 & 0.60 & 1.17 & 0.66 & 2.07 \\
\hline $\begin{array}{l}\text { 32-36 weeks GA vs } \\
\text { controls }\end{array}$ & E2/E4 & 0.05 & 0.04 & E3/E3 & 0.16 & $(0.66)$ & 1.35 & 0.31 & 5.92 \\
\hline
\end{tabular}




\begin{tabular}{|c|c|c|c|c|c|c|c|c|c|}
\hline APOE Comparison & Test genotype & $\begin{array}{l}\text { Frequency of test } \\
\text { genotype in cases }\end{array}$ & $\begin{array}{l}\text { Frequency of test } \\
\text { genotype in controls }\end{array}$ & $\begin{array}{l}\text { Comparison } \\
\text { genotype }\end{array}$ & $\begin{array}{l}\text { Chi Squared } \\
\text { value }\end{array}$ & $\begin{array}{c}\text { P value } \\
\text { (Fischer's } \\
\text { exact) }\end{array}$ & Odds Ratio & Lower $95 \% \mathrm{Cl}$ & Upper 95\% CI \\
\hline $\begin{array}{l}\text { 32-36 weeks GA vs } \\
\text { controls }\end{array}$ & E2/E3 & 0.15 & 0.17 & E3/E3 & 0.17 & 0.73 & 0.87 & 0.38 & 1.97 \\
\hline $\begin{array}{l}\text { 32-36 weeks GA vs } \\
\text { controls }\end{array}$ & E2/E2 & 0.02 & 0.01 & Е3/Е3 & 0.90 & $(0.34)$ & 2.70 & 0.32 & 22.99 \\
\hline$>36$ weeks $G A$ vs controls & E4/E4 & 0.03 & 0.03 & E3/E3 & 0.06 & 0.82 & 0.89 & 0.33 & 2.38 \\
\hline$>36$ weeks $\mathrm{GA}$ vs controls & E3/E4 & 0.25 & 0.27 & E3/E3 & 0.45 & 0.50 & 0.89 & 0.64 & 1.25 \\
\hline$>36$ weeks $\mathrm{GA}$ vs controls & E2/E4 & 0.02 & 0.04 & Е3/Е3 & 0.62 & 0.43 & 0.65 & 0.22 & 1.90 \\
\hline$>36$ weeks $\mathrm{GA}$ vs controls & E2/E3 & 0.16 & 0.17 & Е3/Е3 & 0.05 & 0.83 & 0.96 & 0.63 & 1.46 \\
\hline$>36$ weeks $\mathrm{GA}$ vs controls & E2/E2 & 0.01 & 0.01 & E3/E3 & 0.11 & $(0.67)$ & 1.30 & 0.26 & 6.52 \\
\hline CP vs controls (infection) & E4/E4 & 0.01 & 0.03 & E3/E3 & 2.43 & $(0.15)$ & 0.23 & 0.03 & 1.73 \\
\hline CP vs controls (infection) & E3/E4 & 0.34 & 0.27 & E3/E3 & 3.76 & 0.05 & 1.38 & 1.00 & 1.92 \\
\hline CP vs controls (infection) & E2/E4 & 0.02 & 0.04 & E3/E3 & 0.55 & 0.46 & 0.64 & 0.19 & 2.14 \\
\hline CP vs controls (infection) & E2/E3 & 0.12 & 0.17 & E3/E3 & 2.33 & 0.13 & 0.66 & 0.38 & 1.13 \\
\hline CP vs controls (infection) & E2/E2 & $<0.005$ & 0.01 & E3/E3 & - & - & - & - & - \\
\hline $\begin{array}{l}\text { Hemiplegia vs controls } \\
\text { (infection) }\end{array}$ & E4/E4 & 0.03 & 0.03 & E3/E3 & 0.05 & $(1.00)$ & 0.80 & 0.10 & 6.06 \\
\hline $\begin{array}{l}\text { Hemiplegia vs controls } \\
\text { (infection) }\end{array}$ & E3/E4 & 0.37 & 0.27 & E3/E3 & 2.44 & 0.12 & 1.54 & 0.89 & 2.66 \\
\hline $\begin{array}{l}\text { Hemiplegia vs controls } \\
\text { (infection) }\end{array}$ & E2/E4 & 0.05 & 0.04 & E3/E3 & 0.25 & 0.62 & 1.46 & 0.33 & 6.40 \\
\hline $\begin{array}{l}\text { Hemiplegia vs controls } \\
\text { (infection) }\end{array}$ & E2/E3 & 0.16 & 0.17 & E3/E3 & 0.03 & 0.87 & 0.94 & 0.41 & 2.14 \\
\hline
\end{tabular}




\begin{tabular}{|c|c|c|c|c|c|c|c|c|c|}
\hline APOE Comparison & Test genotype & $\begin{array}{l}\text { Frequency of test } \\
\text { genotype in cases }\end{array}$ & $\begin{array}{l}\text { Frequency of test } \\
\text { genotype in controls }\end{array}$ & $\begin{array}{c}\text { Comparison } \\
\text { genotype }\end{array}$ & $\begin{array}{l}\text { Chi Squared } \\
\text { value }\end{array}$ & $\begin{array}{c}\text { P value } \\
\text { (Fischer's } \\
\text { exact) }\end{array}$ & Odds Ratio & Lower 95\% Cl & Upper 95\% C \\
\hline $\begin{array}{l}\text { Hemiplegia vs controls } \\
\text { (infection) }\end{array}$ & E2/E2 & $<0.005$ & 0.01 & E3/E3 & - & - & - & - & - \\
\hline $\begin{array}{l}\text { Diplegia vs controls } \\
\text { (infection) }\end{array}$ & E4/E4 & $<0.005$ & 0.03 & E3/E3 & - & & - & - & - \\
\hline $\begin{array}{l}\text { Diplegia vs controls } \\
\text { (infection) }\end{array}$ & E3/E4 & 0.42 & 0.27 & E3/E3 & 5.39 & 0.02 & 1.91 & 1.10 & 3.33 \\
\hline $\begin{array}{l}\text { Diplegia vs controls } \\
\text { (infection) }\end{array}$ & E2/E4 & 0.03 & 0.04 & E3/E3 & 0.02 & 0.89 & 0.87 & 0.11 & 6.60 \\
\hline $\begin{array}{l}\text { Diplegia vs controls } \\
\text { (infection) }\end{array}$ & E2/E3 & 0.16 & 0.17 & E3/E3 & 0.01 & 0.91 & 0.95 & 0.39 & 2.32 \\
\hline $\begin{array}{l}\text { Diplegia vs controls } \\
\text { (infection) }\end{array}$ & E2/E2 & $<0.005$ & 0.01 & E3/E3 & - & - & - & - & - \\
\hline $\begin{array}{l}\text { Quadriplegia vs controls } \\
\text { (infection) }\end{array}$ & E4/E4 & $<0.005$ & 0.03 & E3/E3 & - & - & - & - & - \\
\hline $\begin{array}{l}\text { Quadriplegia vs controls } \\
\text { (infection) }\end{array}$ & E3/E4 & 0.22 & 0.27 & E3/E3 & 0.56 & 0.45 & 0.77 & 0.39 & 1.53 \\
\hline $\begin{array}{l}\text { Quadriplegia vs controls } \\
\text { (infection) }\end{array}$ & E2/E4 & $<0.005$ & 0.04 & E3/E3 & - & - & - & - & - \\
\hline $\begin{array}{l}\text { Quadriplegia vs controls } \\
\text { (infection) }\end{array}$ & E2/E3 & 0.05 & 0.17 & E3/E3 & 3.74 & 0.05 & 0.27 & 0.06 & 1.12 \\
\hline $\begin{array}{l}\text { Quadriplegia vs controls } \\
\text { (infection) }\end{array}$ & E2/E2 & $<0.005$ & 0.01 & E3/E3 & - & - & - & - & - \\
\hline $\begin{array}{l}\text { Other CP types vs controls } \\
\text { (infection) }\end{array}$ & E4/E4 & $<0.005$ & 0.03 & E3/E3 & - & - & - & - & - \\
\hline $\begin{array}{l}\text { Other CP types vs controls } \\
\text { (infection) }\end{array}$ & E3/E4 & 0.35 & 0.27 & E3/E3 & 0.63 & 0.43 & 1.42 & 0.59 & 3.39 \\
\hline
\end{tabular}




\begin{tabular}{|c|c|c|c|c|c|c|c|c|c|}
\hline APOE Comparison & Test genotype & $\begin{array}{l}\text { Frequency of test } \\
\text { genotype in cases }\end{array}$ & $\begin{array}{l}\text { Frequency of test } \\
\text { genotype in controls }\end{array}$ & $\begin{array}{l}\text { Comparison } \\
\text { genotype }\end{array}$ & $\begin{array}{l}\text { Chi Squared } \\
\text { value }\end{array}$ & $\begin{array}{c}\text { P value } \\
\text { (Fischer's } \\
\text { exact) }\end{array}$ & Odds Ratio & Lower 95\% Cl & Upper $95 \% \mathrm{C}$ \\
\hline $\begin{array}{l}\text { Other CP types vs controls } \\
\text { (infection) }\end{array}$ & E2/E4 & $<0.005$ & 0.04 & E3/E3 & - & - & - & - & - \\
\hline $\begin{array}{l}\text { Other CP types vs controls } \\
\text { (infection) }\end{array}$ & E2/E3 & 0.06 & 0.17 & E3/E3 & 1.20 & $(0.49)$ & 0.34 & 0.04 & 2.58 \\
\hline $\begin{array}{l}\text { Other } \mathrm{CP} \text { types vs controls } \\
\text { (infection) }\end{array}$ & E2/E2 & $<0.005$ & 0.01 & E3/E3 & - & - & - & - & - \\
\hline $\begin{array}{c}<32 \text { weeks } G A \text { vs controls } \\
\text { (infection) }\end{array}$ & E4/E4 & $<0.005$ & 0.03 & E3/E3 & & - & & - & - \\
\hline $\begin{array}{c}<32 \text { weeks } G A \text { vs controls } \\
\text { (infection) }\end{array}$ & E3/E4 & 0.31 & 0.27 & E3/E3 & 0.40 & 0.53 & 1.22 & 0.66 & 2.24 \\
\hline $\begin{array}{c}<32 \text { weeks } G A \text { vs controls } \\
\text { (infection) }\end{array}$ & E2/E4 & 0.03 & 0.04 & E3/E3 & 0.05 & $(1.00)$ & 0.79 & 0.10 & 6.02 \\
\hline $\begin{array}{c}<32 \text { weeks } G A \text { vs controls } \\
\text { (infection) }\end{array}$ & E2/E3 & 0.05 & 0.17 & E3/E3 & 3.22 & 0.07 & 0.29 & 0.07 & 1.22 \\
\hline $\begin{array}{c}<32 \text { weeks GA vs controls } \\
\text { (infection) }\end{array}$ & E2/E2 & $<0.005$ & 0.01 & E3/E3 & - & - & - & - & - \\
\hline $\begin{array}{l}\text { 32-36 weeks GA vs } \\
\text { controls (infection) }\end{array}$ & E4/E4 & $<0.005$ & 0.03 & E3/E3 & - & - & - & - & - \\
\hline $\begin{array}{l}\text { 32-36 weeks GA vs } \\
\text { controls (infection) }\end{array}$ & E3/E4 & 0.44 & 0.27 & E3/E3 & 3.38 & 0.07 & 2.09 & 0.94 & 4.67 \\
\hline $\begin{array}{l}\text { 32-36 weeks GA vs } \\
\text { controls (infection) }\end{array}$ & E2/E4 & 0.07 & 0.04 & E3/E3 & 0.43 & 0.51 & 1.98 & 0.25 & 15.67 \\
\hline $\begin{array}{l}\text { 32-36 weeks GA vs } \\
\text { controls (infection) }\end{array}$ & E2/E3 & 0.13 & 0.17 & E3/E3 & 0.18 & 0.67 & 0.73 & 0.16 & 3.23 \\
\hline $\begin{array}{l}\text { 32-36 weeks GA vs } \\
\text { controls (infection) }\end{array}$ & E2/E2 & $<0.005$ & 0.01 & E3/E3 & & - & & - & - \\
\hline
\end{tabular}




\begin{tabular}{|c|c|c|c|c|c|c|c|c|c|}
\hline APOE Comparison & Test genotype & $\begin{array}{l}\text { Frequency of test } \\
\text { genotype in cases }\end{array}$ & $\begin{array}{l}\text { Frequency of test } \\
\text { genotype in controls }\end{array}$ & $\begin{array}{c}\text { Comparison } \\
\text { genotype }\end{array}$ & $\begin{array}{l}\text { Chi Squared } \\
\text { value }\end{array}$ & $\begin{array}{c}\text { P value } \\
\text { (Fischer's } \\
\text { exact) }\end{array}$ & Odds Ratio & Lower 95\% Cl & Upper $95 \% \mathrm{CI}$ \\
\hline $\begin{array}{l}>36 \text { weeks GA vs controls } \\
\text { (infection) }\end{array}$ & E4/E4 & 0.01 & 0.03 & E3/E3 & 0.70 & 0.40 & 0.43 & 0.06 & 3.25 \\
\hline $\begin{array}{l}>36 \text { weeks } G A \text { vs controls } \\
\text { (infection) }\end{array}$ & E3/E4 & 0.31 & 0.27 & E3/E3 & 0.52 & 0.47 & 1.18 & 0.75 & 1.84 \\
\hline $\begin{array}{l}>36 \text { weeks } G A \text { vs controls } \\
\text { (infection) }\end{array}$ & E2/E4 & 0.01 & 0.04 & E3/E3 & 0.87 & 0.35 & 0.40 & 0.05 & 2.97 \\
\hline $\begin{array}{l}>36 \text { weeks GA vs controls } \\
\text { (infection) }\end{array}$ & E2/E3 & 0.15 & 0.17 & E3/E3 & 0.18 & 0.67 & 0.87 & 0.46 & 1.65 \\
\hline $\begin{array}{l}>36 \text { weeks } G \text { A vs controls } \\
\text { (infection) }\end{array}$ & E2/E2 & $<0.005$ & 0.01 & E3/E3 & - & - & - & - & \\
\hline
\end{tabular}




\section{Chapter $5 \quad$ Mother's Genetics}

Association with MBL haplotypes

Table 15 reports comparison of all maternal MBL haplotypes between cases and controls, comparing to HYPA/HYPA. Only one haplotype group showed a significant association with cerebral palsy (high producing group, $p=0.03$, odds ratio $0.68,95 \%$ confidence interval $0.48-0.97$ ) at the $p=0.05$ level. Since these tests contributed to 160 tests of MBL association with cerebral palsy, it was appropriate to use a Bonferroni correction to set the significance rate at 0.0003 . No associations were significant at this level and odds ratios approached unity. 


\section{Table 15}

Association of maternal MBL haplotypes between cases and controls.

\begin{tabular}{|c|c|c|c|c|c|c|c|c|c|}
\hline MBL Comparison & $\begin{array}{c}\text { Test } \\
\text { haplotype }\end{array}$ & $\begin{array}{l}\text { Frequency of test } \\
\text { haplotype in cases }\end{array}$ & $\begin{array}{l}\text { Frequency of test } \\
\text { haplotype in controls }\end{array}$ & Comparison haplotype & $\begin{array}{l}\text { Chi Squared } \\
\text { value }\end{array}$ & P value & $\begin{array}{l}\text { Odds } \\
\text { Ratio }\end{array}$ & $\begin{array}{l}\text { Lower } \\
95 \% \mathrm{Cl}\end{array}$ & $\begin{array}{l}\text { Upper } \\
95 \% \mathrm{Cl}\end{array}$ \\
\hline All cases vs controls & HYPA & 0.80 & 0.81 & HYPA/HYPA & 0.05 & 0.83 & 0.96 & 0.67 & 1.38 \\
\hline All cases vs controls & HYPD & 0.57 & 0.54 & HYPA/HYPA & 0.26 & 0.61 & 1.12 & 0.73 & 1.72 \\
\hline All cases vs controls & LYPA & 0.43 & 0.50 & HYPA/HYPA & 1.15 & 0.28 & 0.77 & 0.48 & 1.24 \\
\hline All cases vs controls & LYPB & 0.71 & 0.73 & HYPA/HYPA & 0.26 & 0.61 & 0.91 & 0.62 & 1.33 \\
\hline All cases vs controls & LYQA & 0.77 & 0.80 & HYPA/HYPA & 1.33 & 0.25 & 0.81 & 0.56 & 1.16 \\
\hline All cases vs controls & LYQC & 0.15 & 0.17 & HYPA/HYPA & 0.11 & 0.74 & 0.87 & 0.38 & 1.97 \\
\hline All cases vs controls & LXPA & 0.79 & 0.80 & HYPA/HYPA & 0.10 & 0.75 & 0.94 & 0.66 & 1.35 \\
\hline All cases vs controls & $\begin{array}{l}\text { High } \\
\text { group* }\end{array}$ & 0.54 & 0.58 & HYPA/HYPA & 0.25 & 0.12 & 0.85 & 0.69 & 1.04 \\
\hline All cases vs controls & $\begin{array}{l}\text { Med } \\
\text { group§ }\end{array}$ & 0.26 & 0.22 & HYPA/HYPA & 3.39 & 0.07 & 1.25 & 0.99 & 1.59 \\
\hline All cases vs controls & $\begin{array}{l}\text { Low } \\
\text { group }\end{array}$ & 0.20 & 0.20 & HYPA/HYPA & $<0.005$ & 0.99 & 1.00 & 0.77 & 1.30 \\
\hline Hemiplegia vs controls & HYPA & 0.84 & 0.81 & HYPA/HYPA & 0.75 & 0.39 & 1.30 & 0.72 & 2.34 \\
\hline Hemiplegia vs controls & HYPD & 0.61 & 0.54 & HYPA/HYPA & 0.50 & 0.48 & 1.29 & 0.64 & 2.59 \\
\hline Hemiplegia vs controls & LYPA & 0.44 & 0.50 & HYPA/HYPA & 0.25 & 0.62 & 0.82 & 0.36 & 1.83 \\
\hline Hemiplegia vs controls & LYPB & 0.73 & 0.73 & HYPA/HYPA & $<0.005$ & 0.96 & 1.02 & 0.54 & 1.91 \\
\hline Hemiplegia vs controls & LYQA & 0.80 & 0.80 & HYPA/HYPA & 0.01 & 0.93 & 0.97 & 0.53 & 1.78 \\
\hline Hemiplegia vs controls & LYQC & 0.17 & 0.17 & HYPA/HYPA & $<0.005$ & 0.99 & 0.99 & 0.26 & 3.73 \\
\hline
\end{tabular}




\begin{tabular}{|c|c|c|c|c|c|c|c|c|c|}
\hline MBL Comparison & $\begin{array}{c}\text { Test } \\
\text { haplotype }\end{array}$ & $\begin{array}{l}\text { Frequency of test } \\
\text { haplotype in cases }\end{array}$ & $\begin{array}{c}\text { Frequency of test } \\
\text { haplotype in controls }\end{array}$ & Comparison haplotype & $\begin{array}{l}\text { Chi Squared } \\
\text { value }\end{array}$ & Pvalue & $\begin{array}{l}\text { Odds } \\
\text { Ratio }\end{array}$ & $\begin{array}{l}\text { Lower } \\
95 \% \mathrm{Cl}\end{array}$ & $\begin{array}{l}\text { Upper } \\
95 \% \mathrm{Cl}\end{array}$ \\
\hline Hemiplegia vs controls & LXPA & 0.83 & 0.80 & HYPA/HYPA & 0.44 & 0.51 & 1.22 & 0.67 & 2.22 \\
\hline Hemiplegia vs controls & High group & 0.55 & 0.58 & HYPA/HYPA & 0.62 & 0.43 & 0.88 & 0.64 & 1.21 \\
\hline Hemiplegia vs controls & Med group & 0.26 & 0.22 & HYPA/HYPA & 1.22 & 0.27 & 1.23 & 0.85 & 1.78 \\
\hline Hemiplegia vs controls & Low group & 0.19 & 0.20 & HYPA/HYPA & 0.04 & 0.85 & 0.96 & 0.64 & 1.45 \\
\hline Quadriplegia vs controls & HYPA & 0.81 & 0.81 & HYPA/HYPA & 0.02 & 0.89 & 1.05 & 0.56 & 1.94 \\
\hline Quadriplegia vs controls & HYPD & 0.50 & 0.54 & HYPA/HYPA & 0.19 & 0.66 & 0.84 & 0.38 & 1.84 \\
\hline Quadriplegia vs controls & LYPA & 0.48 & 0.50 & HYPA/HYPA & 0.02 & 0.89 & 0.95 & 0.42 & 2.11 \\
\hline Quadriplegia vs controls & LYPB & 0.71 & 0.73 & HYPA/HYPA & 0.05 & 0.83 & 0.93 & 0.48 & 1.80 \\
\hline Quadriplegia vs controls & LYQA & 0.77 & 0.80 & HYPA/HYPA & 0.27 & 0.61 & 0.85 & 0.45 & 1.60 \\
\hline Quadriplegia vs controls & LYQC & 0.18 & 0.17 & HYPA/HYPA & 0.01 & 0.93 & 1.06 & 0.28 & 4.02 \\
\hline Quadriplegia vs controls & LXPA & 0.79 & 0.80 & HYPA/HYPA & 0.10 & 0.75 & 0.90 & 0.48 & 1.69 \\
\hline Quadriplegia vs controls & High group & 0.57 & 0.58 & HYPA/HYPA & 0.06 & 0.81 & 0.96 & 0.67 & 1.37 \\
\hline Quadriplegia vs controls & Med group & 0.26 & 0.22 & HYPA/HYPA & 0.94 & 0.33 & 1.23 & 0.81 & 1.85 \\
\hline Quadriplegia vs controls & Low group & 0.17 & 0.20 & HYPA/HYPA & 0.54 & 0.46 & 0.84 & 0.52 & 1.35 \\
\hline Diplegia vs controls & HYPA & 0.79 & 0.81 & HYPA/HYPA & 0.12 & 0.73 & 0.90 & 0.49 & 1.65 \\
\hline Diplegia vs controls & HYPD & 0.61 & 0.54 & HYPA/HYPA & 0.50 & 0.48 & 1.29 & 0.64 & 2.59 \\
\hline Diplegia vs controls & LYPA & 0.32 & 0.50 & HYPA/HYPA & 2.50 & 0.11 & 0.48 & 0.19 & 1.22 \\
\hline Diplegia vs controls & LYPB & 0.74 & 0.73 & HYPA/HYPA & 0.02 & 0.90 & 1.04 & 0.55 & 1.96 \\
\hline Diplegia vs controls & LYQA & 0.74 & 0.80 & HYPA/HYPA & 1.34 & 0.25 & 0.69 & 0.37 & 1.30 \\
\hline Diplegia vs controls & LYQC & 0.12 & 0.17 & HYPA/HYPA & 0.28 & 0.60 & 0.66 & 0.14 & 3.11 \\
\hline
\end{tabular}




\begin{tabular}{|c|c|c|c|c|c|c|c|c|c|}
\hline MBL Comparison & $\begin{array}{c}\text { Test } \\
\text { haplotype }\end{array}$ & $\begin{array}{l}\text { Frequency of test } \\
\text { haplotype in cases }\end{array}$ & $\begin{array}{c}\text { Frequency of test } \\
\text { haplotype in controls }\end{array}$ & Comparison haplotype & $\begin{array}{l}\text { Chi Squared } \\
\text { value }\end{array}$ & Pvalue & $\begin{array}{l}\text { Odds } \\
\text { Ratio }\end{array}$ & $\begin{array}{l}\text { Lower } \\
95 \% \mathrm{Cl}\end{array}$ & $\begin{array}{l}\text { Upper } \\
95 \% \mathrm{Cl}\end{array}$ \\
\hline Diplegia vs controls & LXPA & 0.79 & 0.80 & HYPA/HYPA & 0.10 & 0.76 & 0.91 & 0.49 & 1.67 \\
\hline Diplegia vs controls & High group & 0.49 & 0.58 & HYPA/HYPA & 4.52 & 0.03 & 0.68 & 0.48 & 0.97 \\
\hline Diplegia vs controls & Med group & 0.26 & 0.22 & HYPA/HYPA & 0.86 & 0.36 & 1.21 & 0.81 & 1.83 \\
\hline Diplegia vs controls & Low group & 0.26 & 0.20 & HYPA/HYPA & 2.73 & 0.10 & 1.41 & 0.94 & 2.14 \\
\hline Other CP types vs controls & HYPA & 0.72 & 0.81 & HYPA/HYPA & 1.46 & 0.23 & 0.61 & 0.28 & 1.37 \\
\hline Other $\mathrm{CP}$ types vs controls & HYPD & 0.53 & 0.54 & HYPA/HYPA & 0.02 & 0.88 & 0.93 & 0.37 & 2.38 \\
\hline Other CP types vs controls & LYPA & 0.36 & 0.50 & HYPA/HYPA & 1.00 & 0.32 & 0.57 & 0.18 & 1.75 \\
\hline Other $C P$ types vs controls & LYPB & 0.57 & 0.73 & HYPA/HYPA & 2.46 & 0.18 & 0.50 & 0.20 & 1.21 \\
\hline Other CP types vs controls & LYQA & 0.76 & 0.80 & HYPA/HYPA & 0.44 & 0.51 & 0.77 & 0.35 & 1.68 \\
\hline Other $\mathrm{CP}$ types vs controls & LYQC & 0.10 & 0.17 & HYPA/HYPA & 0.31 & 0.58 & 0.55 & 0.07 & 4.58 \\
\hline Other CP types vs controls & LXPA & 0.76 & 0.80 & HYPA/HYPA & 0.43 & 0.51 & 0.77 & 0.35 & 1.68 \\
\hline Other $\mathrm{CP}$ types vs controls & High group & 0.61 & 0.58 & HYPA/HYPA & 0.16 & 0.69 & 1.11 & 0.67 & 1.84 \\
\hline Other CP types vs controls & Med group & 0.24 & 0.22 & HYPA/HYPA & 0.15 & 0.70 & 1.12 & 0.63 & 2.00 \\
\hline Other $\mathrm{CP}$ types vs controls & Low group & 0.15 & 0.20 & HYPA/HYPA & 0.82 & 0.37 & 0.73 & 0.37 & 1.45 \\
\hline$<32$ weeks $G A$ vs controls & HYPA & 0.78 & 0.81 & HYPA/HYPA & 0.31 & 0.58 & 0.85 & 0.48 & 1.51 \\
\hline$<32$ weeks $G A$ vs controls & HYPD & 0.49 & 0.54 & HYPA/HYPA & 0.40 & 0.53 & 0.79 & 0.38 & 1.64 \\
\hline$<32$ weeks $G A$ vs controls & LYPA & 0.43 & 0.50 & HYPA/HYPA & 0.40 & 0.53 & 0.78 & 0.36 & 1.69 \\
\hline$<32$ weeks $G A$ vs controls & LYPB & 0.70 & 0.73 & HYPA/HYPA & 0.19 & 0.67 & 0.87 & 0.48 & 1.61 \\
\hline$<32$ weeks $G A$ vs controls & LYQA & 0.70 & 0.80 & HYPA/HYPA & 3.41 & 0.07 & 0.57 & 0.31 & 1.04 \\
\hline$<32$ weeks $G A$ vs controls & LYQC & 0.06 & 0.17 & HYPA/HYPA & 1.53 & 0.22 & 0.29 & 0.04 & 2.31 \\
\hline
\end{tabular}




\begin{tabular}{|c|c|c|c|c|c|c|c|c|c|}
\hline MBL Comparison & $\begin{array}{c}\text { Test } \\
\text { haplotype }\end{array}$ & $\begin{array}{l}\text { Frequency of test } \\
\text { haplotype in cases }\end{array}$ & $\begin{array}{l}\text { Frequency of test } \\
\text { haplotype in controls }\end{array}$ & Comparison haplotype & $\begin{array}{l}\text { Chi Squared } \\
\text { value }\end{array}$ & Pvalue & $\begin{array}{l}\text { Odds } \\
\text { Ratio }\end{array}$ & $\begin{array}{l}\text { Lower } \\
95 \% \mathrm{CI}\end{array}$ & $\begin{array}{l}\text { Upper } \\
95 \% \text { C }\end{array}$ \\
\hline$<32$ weeks $G A$ vs controls & LXPA & 0.76 & 0.80 & HYPA/HYPA & 0.65 & 0.42 & 0.79 & 0.44 & 1.41 \\
\hline$<32$ weeks $G A$ vs controls & High group & 0.57 & 0.58 & HYPA/HYPA & 0.09 & 0.76 & 0.95 & 0.66 & 1.36 \\
\hline$<32$ weeks $G A$ vs controls & Med group & 0.25 & 0.22 & HYPA/HYPA & 0.68 & 0.41 & 1.19 & 0.79 & 1.80 \\
\hline$<32$ weeks $G A$ vs controls & Low group & 0.18 & 0.20 & HYPA/HYPA & 0.24 & 0.63 & 0.89 & 0.56 & 1.42 \\
\hline 32-36 weeks $\mathrm{GA}$ vs controls & HYPA & 0.83 & 0.81 & HYPA/HYPA & 0.11 & 0.75 & 1.16 & 0.47 & 2.87 \\
\hline 32-36 weeks $\mathrm{GA}$ vs controls & HYPD & 0.63 & 0.54 & HYPA/HYPA & 0.40 & 0.53 & 1.40 & 0.49 & 3.98 \\
\hline 32-36 weeks $G A$ vs controls & LYPA & 0.46 & 0.50 & HYPA/HYPA & 0.07 & 0.79 & 0.85 & 0.25 & 2.87 \\
\hline 32-36 weeks $G A$ vs controls & LYPB & 0.71 & 0.73 & HYPA/HYPA & 0.02 & 0.88 & 0.93 & 0.35 & 2.46 \\
\hline 32-36 weeks $\mathrm{GA}$ vs controls & LYQA & 0.81 & 0.80 & HYPA/HYPA & 0.02 & 0.88 & 1.07 & 0.43 & 2.67 \\
\hline 32-36 weeks GA vs controls & LYQC & 0.25 & 0.17 & HYPA/HYPA & 0.35 & 0.55 & 1.65 & 0.31 & 8.75 \\
\hline 32-36 weeks $G A$ vs controls & LXPA & 0.84 & 0.80 & HYPA/HYPA & 0.29 & 0.59 & 1.28 & 0.52 & 3.15 \\
\hline 32-36 weeks $G A$ vs controls & High group & 0.51 & 0.58 & HYPA/HYPA & 1.49 & 0.22 & 0.74 & 0.46 & 1.20 \\
\hline 32-36 weeks $G A$ vs controls & Med group & 0.27 & 0.22 & HYPA/HYPA & 0.79 & 0.37 & 1.28 & 0.74 & 2.21 \\
\hline 32-36 weeks $G A$ vs controls & Low group & 0.23 & 0.20 & HYPA/HYPA & 0.34 & 0.56 & 1.19 & 0.67 & 2.11 \\
\hline$>36$ weeks $G A$ vs controls & HYPA & 0.82 & 0.81 & HYPA/HYPA & 0.10 & 0.75 & 1.08 & 0.67 & 1.74 \\
\hline$>36$ weeks $G A$ vs controls & HYPD & 0.61 & 0.54 & HYPA/HYPA & 0.80 & 0.37 & 1.29 & 0.74 & 2.26 \\
\hline$>36$ weeks $\mathrm{GA}$ vs controls & LYPA & 0.41 & 0.50 & HYPA/HYPA & 1.08 & 0.30 & 0.71 & 0.37 & 1.37 \\
\hline$>36$ weeks GA vs controls & LYPB & 0.72 & 0.73 & HYPA/HYPA & 0.01 & 0.91 & 0.97 & 0.59 & 1.61 \\
\hline$>36$ weeks $\mathrm{GA}$ vs controls & LYQA & 0.80 & 0.80 & HYPA/HYPA & 0.02 & 0.90 & 0.97 & 0.60 & 1.57 \\
\hline$>36$ weeks $G A$ vs controls & LYQC & 0.21 & 0.17 & HYPA/HYPA & 0.35 & 0.56 & 1.33 & 0.51 & 3.47 \\
\hline
\end{tabular}




\begin{tabular}{|c|c|c|c|c|c|c|c|c|c|}
\hline MBL Comparison & $\begin{array}{c}\text { Test } \\
\text { haplotype }\end{array}$ & $\begin{array}{l}\text { Frequency of test } \\
\text { haplotype in cases }\end{array}$ & $\begin{array}{l}\text { Frequency of test } \\
\text { haplotype in controls }\end{array}$ & Comparison haplotype & $\begin{array}{l}\text { Chi Squared } \\
\text { value }\end{array}$ & P value & $\begin{array}{l}\text { Odds } \\
\text { Ratio }\end{array}$ & $\begin{array}{l}\text { Lower } \\
95 \% \mathrm{CI}\end{array}$ & $\begin{array}{l}\text { Upper } \\
95 \% \mathrm{Cl}\end{array}$ \\
\hline$>36$ weeks $G A$ vs controls & LXPA & 0.80 & 0.80 & HYPA/HYPA & $<0.005$ & 0.97 & 0.99 & 0.61 & 1.60 \\
\hline$>36$ weeks $G A$ vs controls & High group & 0.54 & 0.58 & HYPA/HYPA & 1.32 & 0.25 & 0.86 & 0.65 & 1.12 \\
\hline$>36$ weeks $G A$ vs controls & Med group & 0.27 & 0.22 & HYPA/HYPA & 2.31 & 0.13 & 1.27 & 0.93 & 1.72 \\
\hline$>36$ weeks $\mathrm{GA}$ vs controls & Low group & 0.19 & 0.20 & HYPA/HYPA & 0.03 & 0.86 & 0.97 & 0.69 & 1.36 \\
\hline All CP vs controls (infection) & HYPA & 0.80 & 0.81 & HYPA/HYPA & 0.01 & 0.94 & 0.98 & 0.59 & 1.62 \\
\hline All CP vs controls (infection) & HYPD & 0.51 & 0.54 & HYPA/HYPA & 0.17 & 0.68 & 0.88 & 0.47 & 1.64 \\
\hline All CP vs controls (infection) & LYPA & 0.43 & 0.50 & HYPA/HYPA & 0.66 & 0.42 & 0.75 & 0.38 & 1.49 \\
\hline All CP vs controls (infection) & LYPB & 0.74 & 0.73 & HYPA/HYPA & 0.02 & 0.90 & 1.03 & 0.61 & 1.75 \\
\hline All CP vs controls (infection) & LYQA & 0.77 & 0.80 & HYPA/HYPA & 0.46 & 0.50 & 0.84 & 0.50 & 1.40 \\
\hline All CP vs controls (infection) & LYQC & 0.21 & 0.17 & HYPA/HYPA & 0.25 & 0.62 & 1.29 & 0.47 & 3.56 \\
\hline All CP vs controls (infection) & LXPA & 0.80 & 0.80 & HYPA/HYPA & $<0.005$ & 1.00 & 1.00 & 0.61 & 1.66 \\
\hline All CP vs controls (infection) & High group & 0.54 & 0.58 & HYPA/HYPA & 1.30 & 0.26 & 0.85 & 0.63 & 1.13 \\
\hline All CP vs controls (infection) & Med group & 0.24 & 0.22 & HYPA/HYPA & 0.30 & 0.58 & 1.01 & 0.78 & 1.54 \\
\hline All CP vs controls (infection) & Low group & 0.22 & 0.20 & HYPA/HYPA & 0.69 & 0.41 & 1.16 & 0.82 & 1.64 \\
\hline $\begin{array}{l}\text { Hemiplegia vs controls } \\
\text { (infection) }\end{array}$ & HYPA & 0.81 & 0.81 & HYPA/HYPA & $<0.005$ & 0.96 & 1.02 & 0.46 & 2.27 \\
\hline $\begin{array}{l}\text { Hemiplegia vs controls } \\
\text { (infection) }\end{array}$ & HYPD & 0.50 & 0.54 & HYPA/HYPA & 0.12 & 0.73 & 0.84 & 0.30 & 2.31 \\
\hline $\begin{array}{l}\text { Hemiplegia vs controls } \\
\text { (infection) }\end{array}$ & LYPA & 0.47 & 0.50 & HYPA/HYPA & 0.05 & 0.83 & 0.89 & 0.31 & 2.55 \\
\hline $\begin{array}{l}\text { Hemiplegia vs controls } \\
\text { (infection) }\end{array}$ & LYPB & 0.72 & 0.73 & HYPA/HYPA & $<0.005$ & 0.95 & 0.98 & 0.42 & 2.27 \\
\hline
\end{tabular}




\begin{tabular}{|c|c|c|c|c|c|c|c|c|c|}
\hline MBL Comparison & $\begin{array}{c}\text { Test } \\
\text { haplotype }\end{array}$ & $\begin{array}{l}\text { Frequency of test } \\
\text { haplotype in cases }\end{array}$ & $\begin{array}{l}\text { Frequency of test } \\
\text { haplotype in controls }\end{array}$ & Comparison haplotype & $\begin{array}{l}\text { Chi Squared } \\
\text { value }\end{array}$ & Pvalue & $\begin{array}{l}\text { Odds } \\
\text { Ratio }\end{array}$ & $\begin{array}{l}\text { Lower } \\
95 \% \mathrm{Cl}\end{array}$ & $\begin{array}{l}\text { Upper } \\
95 \% \mathrm{Cl}\end{array}$ \\
\hline $\begin{array}{l}\text { Hemiplegia vs controls } \\
\text { (infection) }\end{array}$ & LYQA & 0.70 & 0.80 & HYPA/HYPA & 1.53 & 0.22 & 0.59 & 0.25 & 1.38 \\
\hline $\begin{array}{l}\text { Hemiplegia vs controls } \\
\text { (infection) }\end{array}$ & LYOC & 0.11 & 0.17 & HYPA/HYPA & 0.20 & 0.66 & 0.62 & 0.07 & 5.22 \\
\hline $\begin{array}{l}\text { Hemiplegia vs controls } \\
\text { (infection) }\end{array}$ & LXPA & 0.79 & 0.80 & HYPA/HYPA & 0.03 & 0.86 & 0.93 & 0.41 & 2.09 \\
\hline $\begin{array}{l}\text { Hemiplegia vs controls } \\
\text { (infection) }\end{array}$ & High group & 0.51 & 0.58 & HYPA/HYPA & 1.54 & 0.21 & 0.74 & 0.46 & 1.19 \\
\hline $\begin{array}{l}\text { Hemiplegia vs controls } \\
\text { (infection) }\end{array}$ & Med group & 0.26 & 0.22 & HYPA/HYPA & 0.57 & 0.45 & 1.23 & 0.72 & 2.12 \\
\hline $\begin{array}{l}\text { Hemiplegia vs controls } \\
\text { (infection) }\end{array}$ & Low group & 0.23 & 0.20 & HYPA/HYPA & 0.56 & 0.46 & 1.24 & 0.71 & 2.18 \\
\hline $\begin{array}{l}\text { Quadriplegia vs controls } \\
\text { (infection) }\end{array}$ & HYPA & 0.80 & 0.81 & HYPA/HYPA & 0.01 & 0.94 & 0.96 & 0.35 & 2.62 \\
\hline $\begin{array}{l}\text { Quadriplegia vs controls } \\
\text { (infection) }\end{array}$ & HYPD & 0.55 & 0.54 & HYPA/HYPA & $<0.005$ & 0.99 & 1.01 & 0.30 & 3.39 \\
\hline $\begin{array}{l}\text { Quadriplegia vs controls } \\
\text { (infection) }\end{array}$ & LYPA & 0.38 & 0.50 & HYPA/HYPA & 0.45 & 0.51 & 0.61 & 0.14 & 2.63 \\
\hline $\begin{array}{l}\text { Quadriplegia vs controls } \\
\text { (infection) }\end{array}$ & LYPB & 0.69 & 0.73 & HYPA/HYPA & 0.14 & 0.71 & 0.82 & 0.28 & 2.41 \\
\hline $\begin{array}{l}\text { Quadriplegia vs controls } \\
\text { (infection) }\end{array}$ & LYQA & 0.79 & 0.80 & HYPA/HYPA & 0.02 & 0.90 & 0.94 & 0.34 & 2.57 \\
\hline $\begin{array}{l}\text { Quadriplegia vs controls } \\
\text { (infection) }\end{array}$ & LYOC & 0.29 & 0.17 & HYPA/HYPA & 0.64 & 0.42 & 1.98 & 0.36 & 10.90 \\
\hline $\begin{array}{l}\text { Quadriplegia vs controls } \\
\text { (infection) }\end{array}$ & LXPA & 0.83 & 0.80 & HYPA/HYPA & 0.03 & 0.87 & 1.09 & 0.40 & 2.95 \\
\hline $\begin{array}{l}\text { Quadriplegia vs controls } \\
\text { (infection) }\end{array}$ & High group & 0.58 & 0.58 & HYPA/HYPA & $<0.005$ & 0.95 & 0.98 & 0.56 & 1.73 \\
\hline
\end{tabular}




\begin{tabular}{|c|c|c|c|c|c|c|c|c|c|}
\hline MBL Comparison & $\begin{array}{c}\text { Test } \\
\text { haplotype }\end{array}$ & $\begin{array}{l}\text { Frequency of test } \\
\text { haplotype in cases }\end{array}$ & $\begin{array}{c}\text { Frequency of test } \\
\text { haplotype in controls }\end{array}$ & Comparison haplotype & $\begin{array}{l}\text { Chi Squared } \\
\text { value }\end{array}$ & Pvalue & $\begin{array}{l}\text { Odds } \\
\text { Ratio }\end{array}$ & $\begin{array}{l}\text { Lower } \\
95 \% \mathrm{CI}\end{array}$ & $\begin{array}{l}\text { Upper } \\
95 \% \text { C }\end{array}$ \\
\hline $\begin{array}{l}\text { Quadriplegia vs controls } \\
\text { (infection) }\end{array}$ & Med group & 0.19 & 0.22 & HYPA/HYPA & 0.26 & 0.61 & 0.83 & 0.41 & 1.69 \\
\hline $\begin{array}{l}\text { Quadriplegia vs controls } \\
\text { (infection) }\end{array}$ & Low group & 0.23 & 0.20 & HYPA/HYPA & 0.36 & 0.55 & 1.22 & 0.63 & 2.38 \\
\hline Diplegia vs controls (infection) & HYPA & 0.79 & 0.81 & HYPA/HYPA & 0.07 & 0.80 & 0.89 & 0.38 & 2.11 \\
\hline Diplegia vs controls (infection) & HYPD & 0.42 & 0.54 & HYPA/HYPA & 0.74 & 0.39 & 0.60 & 0.19 & 1.94 \\
\hline Diplegia vs controls (infection) & LYPA & 0.22 & 0.50 & HYPA/HYPA & 2.57 & 0.11 & 0.29 & 0.06 & 1.44 \\
\hline Diplegia vs controls (infection) & LYPB & 0.75 & 0.73 & HYPA/HYPA & 0.06 & 0.81 & 1.11 & 0.46 & 2.70 \\
\hline Diplegia vs controls (infection) & LYQA & 0.75 & 0.80 & HYPA/HYPA & 0.45 & 0.50 & 0.74 & 0.31 & 1.79 \\
\hline Diplegia vs controls (infection) & LYQC & 0.13 & 0.17 & HYPA/HYPA & 0.10 & 0.75 & 0.71 & 0.08 & 6.06 \\
\hline Diplegia vs controls (infection) & LXPA & 0.79 & 0.80 & HYPA/HYPA & 0.04 & 0.85 & 0.92 & 0.39 & 2.18 \\
\hline Diplegia vs controls (infection) & High group & 0.54 & 0.58 & HYPA/HYPA & 0.38 & 0.54 & 0.85 & 0.51 & 1.43 \\
\hline Diplegia vs controls (infection) & Med group & 0.23 & 0.22 & HYPA/HYPA & 0.02 & 0.89 & 1.04 & 0.57 & 1.93 \\
\hline Diplegia vs controls (infection) & Low group & 0.23 & 0.20 & HYPA/HYPA & 0.39 & 0.53 & 1.22 & 0.66 & 2.25 \\
\hline $\begin{array}{l}\text { Other CP types vs controls } \\
\text { (infection) }\end{array}$ & HYPA & 0.86 & 0.81 & HYPA/HYPA & 0.23 & 0.63 & 1.44 & 0.32 & 6.54 \\
\hline $\begin{array}{l}\text { Other CP types vs controls } \\
\text { (infection) }\end{array}$ & HYPD & 0.50 & 0.54 & HYPA/HYPA & 0.03 & 0.86 & 0.84 & 0.12 & 6.06 \\
\hline $\begin{array}{l}\text { Other CP types vs controls } \\
\text { (infection) }\end{array}$ & LYPA & 0.50 & 0.50 & HYPA/HYPA & $<0.005$ & 0.99 & 1.02 & 0.14 & 7.38 \\
\hline $\begin{array}{l}\text { Other CP types vs controls } \\
\text { (infection) }\end{array}$ & LYPB & 0.71 & 0.73 & HYPA/HYPA & 0.01 & 0.93 & 0.93 & 0.18 & 4.86 \\
\hline $\begin{array}{l}\text { Other CP types vs controls } \\
\text { (infection) }\end{array}$ & LYQA & 0.88 & 0.80 & HYPA/HYPA & 0.68 & 0.41 & 1.85 & 0.42 & 8.23 \\
\hline
\end{tabular}




\begin{tabular}{|c|c|c|c|c|c|c|c|c|c|}
\hline MBL Comparison & $\begin{array}{c}\text { Test } \\
\text { haplotype }\end{array}$ & $\begin{array}{l}\text { Frequency of test } \\
\text { haplotype in cases }\end{array}$ & $\begin{array}{c}\text { Frequency of test } \\
\text { haplotype in controls }\end{array}$ & Comparison haplotype & $\begin{array}{l}\text { Chi Squared } \\
\text { value }\end{array}$ & Pvalue & $\begin{array}{l}\text { Odds } \\
\text { Ratio }\end{array}$ & $\begin{array}{l}\text { Lower } \\
95 \% \mathrm{Cl}\end{array}$ & $\begin{array}{l}\text { Upper } \\
95 \% \mathrm{Cl}\end{array}$ \\
\hline $\begin{array}{l}\text { Other } \mathrm{CP} \text { types vs controls } \\
\text { (infection) }\end{array}$ & LYQC & 0.33 & 0.17 & HYPA/HYPA & 0.56 & 0.45 & 2.48 & 0.22 & 28.58 \\
\hline $\begin{array}{l}\text { Other CP types vs controls } \\
\text { (infection) }\end{array}$ & LXPA & 0.85 & 0.80 & HYPA/HYPA & 0.16 & 0.69 & 1.36 & 0.30 & 6.24 \\
\hline $\begin{array}{l}\text { Other CP types vs controls } \\
\text { (infection) }\end{array}$ & High group & 0.67 & 0.58 & HYPA/HYPA & 0.79 & 0.37 & 1.44 & 0.64 & 3.24 \\
\hline $\begin{array}{l}\text { Other CP types vs controls } \\
\text { (infection) }\end{array}$ & Med group & 0.22 & 0.22 & HYPA/HYPA & $<0.005$ & 1.00 & 1.00 & 0.40 & 2.51 \\
\hline $\begin{array}{l}\text { Other CP types vs controls } \\
\text { (infection) }\end{array}$ & Low group & 0.11 & 0.20 & HYPA/HYPA & 0.12 & 0.27 & 0.51 & 0.15 & 1.71 \\
\hline $\begin{array}{l}<32 \text { weeks } G A \text { vs controls } \\
\text { (infection) }\end{array}$ & HYPA & 0.78 & 0.81 & HYPA/HYPA & 0.13 & 0.72 & 0.84 & 0.33 & 2.14 \\
\hline $\begin{array}{c}<32 \text { weeks GA vs controls } \\
\text { (infection) }\end{array}$ & HYPD & 0.46 & 0.54 & HYPA/HYPA & 0.34 & 0.65 & 0.70 & 0.21 & 2.36 \\
\hline $\begin{array}{c}<32 \text { weeks } G A \text { vs controls } \\
\text { (infection) }\end{array}$ & LYPA & 0.33 & 0.50 & HYPA/HYPA & 0.90 & 0.34 & 0.51 & 0.12 & 2.09 \\
\hline $\begin{array}{l}<32 \text { weeks GA vs controls } \\
\text { (infection) }\end{array}$ & LYPB & 0.70 & 0.73 & HYPA/HYPA & 0.08 & 0.78 & 0.87 & 0.32 & 2.32 \\
\hline $\begin{array}{c}<32 \text { weeks } G A \text { vs controls } \\
\text { (infection) }\end{array}$ & LYQA & 0.73 & 0.80 & HYPA/HYPA & 0.73 & 0.39 & 0.66 & 0.25 & 1.73 \\
\hline $\begin{array}{c}<32 \text { weeks } G A \text { vs controls } \\
\text { (infection) }\end{array}$ & LYQC & 0.14 & 0.17 & HYPA/HYPA & 0.03 & 0.86 & 0.83 & 0.09 & 7.22 \\
\hline $\begin{array}{c}<32 \text { weeks GA vs controls } \\
\text { (infection) }\end{array}$ & LXPA & 0.76 & 0.80 & HYPA/HYPA & 0.26 & 0.61 & 0.78 & 0.31 & 2.01 \\
\hline $\begin{array}{c}<32 \text { weeks GA vs controls } \\
\text { (infection) }\end{array}$ & High group & 0.59 & 0.58 & HYPA/HYPA & 0.02 & 0.88 & 1.05 & 0.58 & 1.87 \\
\hline $\begin{array}{c}<32 \text { weeks } G A \text { vs controls } \\
\text { (infection) }\end{array}$ & Med group & 0.22 & 0.22 & HYPA/HYPA & $<0.005$ & 0.97 & 1.01 & 0.51 & 2.01 \\
\hline
\end{tabular}




\begin{tabular}{|c|c|c|c|c|c|c|c|c|c|}
\hline MBL Comparison & $\begin{array}{c}\text { Test } \\
\text { heplotype }\end{array}$ & $\begin{array}{l}\text { Frequency of test } \\
\text { haplotype in cases }\end{array}$ & $\begin{array}{c}\text { Frequency of test } \\
\text { haplotype in controls }\end{array}$ & Comparison haplotype & $\begin{array}{l}\text { Chi Squared } \\
\text { value }\end{array}$ & Pvalue & $\begin{array}{l}\text { Odds } \\
\text { Ratio }\end{array}$ & $\begin{array}{l}\text { Lower } \\
95 \% \mathrm{Cl}\end{array}$ & $\begin{array}{l}\text { Upper } \\
95 \% \mathrm{Cl}\end{array}$ \\
\hline $\begin{array}{c}<32 \text { weeks GA vs controls } \\
\text { (infection) }\end{array}$ & Low group & 0.18 & 0.20 & HYPA/HYPA & 0.05 & 0.82 & 0.92 & 0.44 & 1.92 \\
\hline $\begin{array}{l}\text { 32-36 weeks GA vs controls } \\
\text { (infection) }\end{array}$ & HYPA & 0.77 & 0.81 & HYPA/HYPA & 0.11 & 0.74 & 0.80 & 0.22 & 2.96 \\
\hline $\begin{array}{l}\text { 32-36 weeks GA vs controls } \\
\text { (infection) }\end{array}$ & HYPD & 0.25 & 0.54 & HYPA/HYPA & 1.37 & 0.24 & 0.28 & 0.03 & 2.73 \\
\hline $\begin{array}{l}\text { 32-36 weeks GA vs controls } \\
\text { (infection) }\end{array}$ & LYPA & 0.40 & 0.50 & HYPA/HYPA & 0.18 & 0.67 & 0.68 & 0.11 & 4.15 \\
\hline $\begin{array}{l}\text { 32-36 weeks GA vs controls } \\
\text { (infection) }\end{array}$ & LYPB & 0.63 & 0.73 & HYPA/HYPA & 0.43 & 0.51 & 0.62 & 0.15 & 2.64 \\
\hline $\begin{array}{l}\text { 32-36 weeks GA vs controls } \\
\text { (infection) }\end{array}$ & LYQA & 0.81 & 0.80 & HYPA/HYPA & 0.01 & 0.92 & 1.07 & 0.30 & 3.83 \\
\hline $\begin{array}{l}\text { 32-36 weeks GA vs controls } \\
\text { (infection) }\end{array}$ & LYQC & 0.40 & 0.17 & HYPA/HYPA & 1.78 & 0.18 & 3.30 & 0.52 & 20.99 \\
\hline $\begin{array}{l}\text { 32-36 weeks GA vs controls } \\
\text { (infection) }\end{array}$ & LXPA & 0.83 & 0.80 & HYPA/HYPA & 0.11 & 0.74 & 1.24 & 0.35 & 4.36 \\
\hline $\begin{array}{l}\text { 32-36 weeks GA vs controls } \\
\text { (infection) }\end{array}$ & High group & 0.62 & 0.58 & HYPA/HYPA & 0.18 & 0.67 & 1.18 & 0.55 & 2.52 \\
\hline $\begin{array}{l}\text { 32-36 weeks GA vs controls } \\
\text { (infection) }\end{array}$ & Med group & 0.21 & 0.22 & HYPA/HYPA & 0.04 & 0.85 & 0.91 & 0.37 & 2.27 \\
\hline $\begin{array}{l}\text { 32-36 weeks GA vs controls } \\
\text { (infection) }\end{array}$ & Low group & 0.17 & 0.20 & HYPA/HYPA & 0.11 & 0.74 & 0.85 & 0.32 & 2.26 \\
\hline $\begin{array}{c}>36 \text { weeks } \mathrm{GA} \text { vs controls } \\
\text { (infection) }\end{array}$ & HYPA & 0.82 & 0.81 & HYPA/HYPA & 0.12 & 0.73 & 1.12 & 0.58 & 2.17 \\
\hline $\begin{array}{l}>36 \text { weeks } G A \text { vs controls } \\
\text { (infection) }\end{array}$ & HYPD & 0.54 & 0.54 & HYPA/HYPA & $<0.005$ & 0.96 & 0.98 & 0.43 & 2.21 \\
\hline $\begin{array}{c}>36 \text { weeks } G A \text { vs controls } \\
\text { (infection) }\end{array}$ & LYPA & 0.40 & 0.50 & HYPA/HYPA & 0.66 & 0.42 & 0.68 & 0.27 & 1.73 \\
\hline
\end{tabular}




\begin{tabular}{|c|c|c|c|c|c|c|c|c|c|}
\hline MBL Comparison & $\begin{array}{c}\begin{array}{c}\text { Test } \\
\text { haplotype }\end{array} \\
\text { (n) }\end{array}$ & $\begin{array}{l}\text { Frequency of test } \\
\text { haplotype in cases }\end{array}$ & $\begin{array}{c}\begin{array}{c}\text { Frequency of test } \\
\text { haplotype in controls }\end{array} \\
\text {. }\end{array}$ & Comparison haplotype & $\begin{array}{l}\text { Chi Squared } \\
\text { value }\end{array}$ & P value & $\begin{array}{l}\text { Odds } \\
\text { Ratio }\end{array}$ & $\begin{array}{l}\text { Lower } \\
95 \% \mathrm{Cl}\end{array}$ & $\begin{array}{l}\text { Upper } \\
\text { 95\% CI }\end{array}$ \\
\hline $\begin{array}{l}>36 \text { weeks GA vs controls } \\
\text { (infection) }\end{array}$ & LYPB & 0.76 & 0.73 & HYPA/HYPA & 0.15 & 0.70 & 1.15 & 0.58 & 2.28 \\
\hline $\begin{array}{l}>36 \text { weeks GA vs controls } \\
\text { (infection) }\end{array}$ & LYQA & 0.77 & 0.80 & HYPA/HYPA & 0.31 & 0.58 & 0.82 & 0.42 & 1.63 \\
\hline $\begin{array}{l}>36 \text { weeks GA vs controls } \\
\text { (infection) }\end{array}$ & LYQC & 0.20 & 0.17 & HYPA/HYPA & 0.10 & 0.76 & 1.24 & 0.32 & 4.77 \\
\hline $\begin{array}{l}>36 \text { weeks GA vs controls } \\
\text { (infection) }\end{array}$ & LXPA & 0.79 & 0.80 & HYPA/HYPA & 0.05 & 0.83 & 0.93 & 0.47 & 1.82 \\
\hline $\begin{array}{l}>36 \text { weeks GA vs controls } \\
\text { (infection) }\end{array}$ & High group & 0.51 & 0.58 & HYPA/HYPA & 2.10 & 0.15 & 0.76 & 0.52 & 1.10 \\
\hline $\begin{array}{l}>36 \text { weeks GA vs controls } \\
\text { (infection) }\end{array}$ & Med group & 0.26 & 0.22 & HYPA/HYPA & 1.11 & 0.29 & 1.26 & 0.82 & 1.92 \\
\hline $\begin{array}{l}>36 \text { weeks GA vs controls } \\
\text { (infection) }\end{array}$ & Low group & 0.22 & 0.20 & HYPA/HYPA & 0.47 & 0.49 & 1.17 & 0.75 & 1.85 \\
\hline
\end{tabular}

*High producing haplotypes included HYPA/HYPA +HYPA/LYPA + HYPA/LYQA + LYPA/LYQA + LYPA/LYPA +LYQA/LYQA + LXPA/HYPA + LXPA/LYQA + LXPA/LYPA, § medium producing haplotypes included HYPA/HYPD + HYPA/LYPB + HYPA/LYQC + HYPD/LYPA + HYPD/LYQA + LYPA/LYPB +LYPA/LYQC + LYPA/LYPD + LYPB/LYQA + l low producing haplotypes included LXPA/LXPA + LXPA/LXPB + LXPA/LYQC + HYPD/LYPB + HYPD/HYPD + $L Y P B / L Y Q C+L Y P B / L Y P B+L Y Q C / L Y Q C$. All groups were taken from ${ }^{80}$. 


\section{Chapter 5 Mother's Genetics}

\section{Discussion}

This pilot study did not uncover any significant associations between maternal genotype and cerebral palsy in the infant.

Only one small study has examined maternal genotype as a potential risk factor for cerebral palsy in the child. Reid et al. ${ }^{44}$ examine maternal carriage of Factor V Leiden in 224 mothers of children with cerebral palsy. This cohort included children with and without radiological evidence of a thrombotic event and maternal Factor $V$ Leiden frequency was compared to population data. Factor $V$ Leiden was found in $7.5 \%$ of mothers in their cohort, a statistically significant increase when compared to a presumed population frequency of $3.6 \%$ $(p=0.021)$.

Our analysis uncovered a similar association with a 3.4\% maternal frequency of Factor $\mathrm{V}$ Leiden in case mothers compared to $2.3 \%$ in our control mothers $(p=0.05$, odds ratio $1.51,95 \%$ confidence interval 1.00-2.28). Maternal Factor $V$ Leiden was also associated with cerebral palsy in cases born at $<32$ weeks ( $p=0.009$, odds ratio $2.10,95 \%$ confidence interval $1.19-3.71)$ and hemiplegic cases ( $p=0.007$, odds ratio $2.06,95 \%$ confidence interval $1.20-3.55$ ). In the context of the present study, Bonferroni correction for multiple testing was appropriate and these associations were not considered significant. Our cohort was $~ 2.5$ times larger than the cohort described by Reid et al. (587 cases vs 224 cases). Importantly, our study recruited a control cohort of mothers. The mothers in our case and control cohorts were drawn from the same population (Australians of Caucasian background with a participating child aged between five and 18 years), provided DNA in the same way (buccal swabs) and were genotyped at the same time. Our maternal control frequency of Factor $\mathrm{V}$ Leiden $(2.3 \%)$ is similar to the Australian population data cited by Reid et al. (3.6\%) and comparable to other Australian studies $(5.3 \%)^{104}$. One study has reported higher levels of Factor V Leiden in the Australian population $(9.5 \%)^{92}$, however the report does not describe a comparable maternal population. The population sample of Gibson et 


\section{Chapter $5 \quad$ Mother's Genetics}

al. was taken from neonates born in a tertiary hospital and these are more likely to experience high risk pregnancies when compared to the wider population. Pregnancy complications such as preeclampsia, recurrent miscarriage and small for gestational age are likely to be overrepresented in their sample, with all of these complications linked to Factor $V$ Leiden carriage ${ }^{105,106}$. This, along with poor quality DNA sourced from Guthrie cards may explain why a high frequency of Factor V Leiden is reported.

Prothrombin gene mutation, another thrombophilic SNP, is reported in chapter 4 to be marginally associated with hemiplegic cerebral palsy cases born at $<32$ weeks and with reported infection. This SNP does not appear to be a risk factor when carried in the maternal genome, possibly suggesting its link to cerebral palsy is more likely to be related to fetal stroke rather than pregnancy complications.

Previous studies have examined fetal SNPs in inflammatory genes as a risk factor for cerebral palsy and identified positive correlations ${ }^{568687}$. Since cytokines have been reported to cross the placenta ${ }^{74}$, and intrauterine infection and chorioamnionitis have both been associated

with cerebral palsy ${ }^{68} 75$, we extended these studies by examining maternal inflammatory SNPs with cerebral palsy outcome. Our study considered cerebral palsy subtype and gestational age and uncovered 24 associations between maternal genotype and infant cerebral palsy outcome; however no tests remained significant after correction for multiple testing. The tests reported here consider each SNP in isolation and it remains a possibility that SNP interactions, including those between mother and fetus and between SNPs and epidemiological triggers may be linked with cerebral palsy.

These results remain to be confirmed in a new cohort, ideally of larger sample size to increase the power. Our requirement for Bonferroni correction of significance may have lead to false negative results, however nearly all odds ratios were close to unity. As there is only one other study of maternal genotype and cerebral palsy, we are unable to compare the odds ratio 


\section{Chapter $5 \quad$ Mother's Genetics}

directions with previous studies as reported for the child's genetic tests. A meta-analysis of this type would help to clarify the ambiguity of these results; however there is currently no statistical trend suggesting that the maternal SNPs, genotypes or haplotypes investigated influence the risk of cerebral palsy outcome. 
Chapter 5 Mother's Genetics

\section{Conclusions}

When considering our panel of 35 candidate SNPs in a univariable analysis, maternal genotype is unlikely to be associated with cerebral palsy outcome in the infant. 
Epidemiology 
Chapter $6 \quad$ Epidemiology

Chapter 6 Epidemiology 


\section{Chapter $6 \quad$ Epidemiology}

\section{Epidemiological Risk Factors Associated with Cerebral Palsy in a Large Case-Control Study*}

O'Callaghan $\mathrm{ME}^{1}$, MacLennan $\mathrm{AH}^{1}$, Gibson $\mathrm{CS}^{1}, \mathrm{McMichael} \mathrm{GL}^{1}$, Haan $\mathrm{EA}^{2}$, Broadbent $\mathrm{JL}^{1}$, Priest $\mathrm{K}^{3}$, Goldwater $\mathrm{PN}^{4}$, Dekker $\mathrm{GA}^{1}$, for the Australian Collaborative Cerebral Palsy Research Group.

Manuscript in preparation.

${ }^{1}$ Discipline of Obstetrics and Gynaecology, School of Paediatrics and Reproductive Health, The Robinson Institute, University of Adelaide, South Australia.

${ }^{2}$ SA Clinical Genetics Service, SA Pathology at Women's and Children's Hospital and Discipline of Paediatrics, The University of Adelaide, South Australia.

${ }^{3}$ Epidemiology Branch, SA Health, South Australia

${ }^{4}$ Departments of Microbiology and Infectious Diseases, SA Pathology at Women's and Children's Hospital, South Australia.

* Manuscript in preparation appears in this thesis as Chapter 6 
Chapter 6 Epidemiology

\section{Statement of authorship}

Epidemiological Risk Factors Associated with Cerebral Palsy in a Large Case-Control Study

Manuscript in preparation.

O'Callaghan ME (Candidate)

Participated in all aspects of this manuscript including the design, laboratory work, ethics submissions, recruitment, data linkage, statistical analysis, interpretation of this study and preparation of the manuscript.

I hereby certify that the statement of contribution is accurate

\section{MacLennan AH}

Principal supervisor, contributed to the study design, data interpretation and manuscript.

I hereby certify that the statement of contribution is accurate 


\section{Chapter $6 \quad$ Epidemiology}

\section{Gibson CS}

Contributed to the study design, data interpretation and manuscript.

I hereby certify that the statement of contribution is accurate

\section{McMichael GL}

Contributed to the laboratory work and manuscript.

I hereby certify that the statement of contribution is accurate

\section{Haan EA}

Co-supervisor, contributed to the study design, data interpretation and manuscript.

I hereby certify that the statement of contribution is accurate 


\section{Chapter $6 \quad$ Epidemiology}

\section{Broadbent J}

Contributed to the ethics submissions, participant recruitment and manuscript.

I hereby certify that the statement of contribution is accurate

\section{Priest K}

Contributed to the data linkage and manuscript.

I hereby certify that the statement of contribution is accurate

\section{Goldwater PN}

Contributed to the study design, data interpretation and manuscript.

I hereby certify that the statement of contribution is accurate 


\section{Chapter $6 \quad$ Epidemiology}

\section{Dekker GA}

Co-supervisor, contributed to the study design, data interpretation and manuscript.

I hereby certify that the statement of contribution is accurate

\section{The Australian Collaborative Cerebral Palsy Research Group}

A multidisciplinary group chaired by Professor Alastair MacLennan, who is Head of the Discipline of Obstetrics and Gynaecology in the School of Paediatrics and Reproductive Health at the University of Adelaide. All named authors of this paper are members of the group and wrote the paper on the group's behalf (group listed in acknowledgements). 


\section{Chapter $6 \quad$ Epidemiology}

\section{Abstract}

Introduction

Many epidemiological risk factors for cerebral palsy have been described in the literature. This chapter confirms the known risk factors for cerebral palsy in this cohort, examines them in more detail and hypothesises new associations.

\section{Methods}

Data was collected using a maternal questionnaire and by linking to state based perinatal repositories. The cohort included 587 cases and 1,154 controls. All tests were specified in chapter 2 and comparisons were made using a chi squared test with $p<0.05$ considered significant.

\section{Results}

The following factors were associated with cerebral palsy: recorded maternal infection during pregnancy (odds ratio $1.55,95 \%$ confidence interval 1.26-1.91, $\mathrm{p}<0.0005$ ), small for gestational age (birth weight $<10^{\text {th }}$ centile - using customised centiles odds ratio $4.35,95 \%$ confidence interval 2.92-6.48, $\mathrm{p}<0.0005$ ), gestational age $<32$ weeks (odds ratio $59.20,95 \%$ confidence interval 28.87-121.38, $\mathrm{p}<0.0005$ ), multiple births (odds ratio $6.62,95 \%$ confidence interval 4.00-10.95, p<0.0005), a relation with cerebral palsy (odds ratio $1.61,95 \%$ confidence interval 1.12-2.32, $\mathrm{p}=0.010$ ), breech position (odds ratio $2.48,95 \%$ confidence interval 1.76-3.49, $p<0.0005$ ), bleeding at any time in pregnancy (odds ratio $2.04,95 \%$ confidence interval $1.61-2.58$, $p<0.0005$ ), low one and five minute Apgar score (odds ratio 20.27, 95\% confidence interval 11.29-36.42, $\mathrm{p}<0.0005$; and odds ratio $51.27,95 \%$ confidence interval 12.20-215.47, Fischer's exact $p<0.0005$, respectively), male gender (odds ratio $1.68,95 \%$ confidence interval $1.38-2.06$, p $<0.0005$ ), emergency and elective Caesarean section (odds ratio $2.42,95 \%$ confidence interval 1.88-3.12, $p<0.0005$; and odds ratio $1.39,95 \%$ confidence interval 1.00-1.94, $p=0.050$, respectively), previous miscarriage (odds ratio $2.30,95 \%$ confidence interval $1.38-3.82, p=0.001$ ), 


\section{Chapter $6 \quad$ Epidemiology}

nuchal cord or cord entanglement (odds ratio $1.86,95 \%$ confidence interval 1.28-2.71, $\mathrm{p}=0.001$ ), smoking (odds ratio $1.37,95 \%$ confidence interval 1.02-1.85, $\mathrm{p}=0.037$ ) and illicit drug use (odds ratio $2.22,95 \%$ confidence interval $1.14-4.30, p=0.016)$. Factors not associated with cerebral palsy were "disappearing twin" on ultrasound, diabetes, maternal body mass index, pregnancy hypertension, alcohol consumption, anaemia, maternal hypothyroidism, forceps or vacuum delivery and maternal age. Use of heat in labour was inversely correlated with cerebral palsy outcome (odds ratio $0.466,95 \%$ confidence interval $0.36-0.61, p<0.0005$ )

\section{Conclusions}

Many obstetric risk factors are associated with cerebral palsy with preterm birth, intrauterine growth restriction, multiple birth and low Apgar scores presenting the largest risks. The observed relation between heat during labour and cerebral palsy may be the result of confounding and requires clearer definition and replication before clinical practice recommendations can be made. 


\section{Chapter 6 Epidemiology}

\section{Introduction}

Cerebral palsy has been investigated extensively for epidemiological risk factors with research dating back to the 1970 s $^{107}{ }^{108}$. A number of key factors have been well established as associated with cerebral palsy including preterm birth, birth weight, infection in pregnancy and twins 109110111112113 . These have been established from population wide databases with near complete ascertainment and a low likelihood of bias.

The cohort for the Australian cerebral palsy research study was examined for these known risk factors for cerebral palsy as well as others that have been little investigated to date. While the case and control cohorts are not true population samples, data presented in chapter 2 has shown good correlation between the cohorts and the wider population. Previously reported studies have usually been population based and have assessed up to 7,242 cerebral palsy cases

111. However prospective data collection in the current study has provided opportunity to collect data that is not routinely available from state perinatal databases. For example, knowing maternal weight at the beginning of pregnancy and height has allowed assessment of maternal body mass index (BMI) as a risk factor for cerebral palsy and the calculation of customised centiles for birth weight. Data was also gathered about infection type and timing. Data about the use of hot packs, hot showers or hot baths during labour allowed assessment of heat during labour as a risk factor for cerebral palsy. Data on plurality at first trimester ultrasound and birth allowed assessment of the 'disappearing twin' hypothesis as a risk factor. 


\section{Chapter $6 \quad$ Epidemiology}

\section{Methods}

Epidemiological data was collected by maternal questionnaire administered to both cases and controls. Perinatal data was collected from the department of health in the state where each child was born. Where data was provided in both the questionnaire and state perinatal data set, perinatal data was used in preference. The questionnaire and perinatal data fields are described in detail in chapter 2 with data quality control described in chapter 3.

Comparison between cases and controls was made using a chi squared test and PASW software v17.0.2 (SPSS Inc. Chicago, III); $p<0.05$ was considered significant. The tests have been detailed in chapter 2 and are listed below:

Maternal infection during pregnancy

Intrauterine growth restriction

Gestational age

Multiple births

Sibling or parent with cerebral palsy

Breech position

"Disappearing twin" on ultrasound

Use of heat in labour

Ante-partum haemorrhage

Diabetes

Maternal body mass index

Pregnancy hypertension

Nuchal cord or cord entanglement 


\section{Chapter $6 \quad$ Epidemiology}

Smoking, alcohol consumption and illicit drug use

Anaemia

Maternal hypothyroidism

Other comparisons conducted which were not specified explicitly in the protocol include:

Apgar score at 1 and 5 minutes

Gender

Delivery type

Maternal age

Previous miscarriage 


\section{Results}

\section{Maternal infection during pregnancy}

Any maternal infection reported in the questionnaire or perinatal data was significantly associated with cerebral palsy outcome (odds ratio 1.55, 95\% confidence interval 1.26-1.91, $\mathrm{p}<0.0005 ;$ Table 1). The maternal questionnaire allowed retrospective and subjective investigation of infection type and timing during pregnancy based on maternal recollection. This allowed investigation of some antenatal infections not routinely recorded by midwives in the state perinatal data set. While some infections presenting early during pregnancy were significantly associated with cerebral palsy outcome (questionnaire reported herpes [0-20 weeks gestational age], odds ratio $2.00,95 \%$ confidence interval 1.01-3.94, $p=0.043$; questionnaire reported other infections i.e. not upper respiratory tract infections, gastrointestinal infections, herpes or fevers [0-20 weeks gestational age], odds ratio $2.13,95 \%$ confidence interval 1.04-4.33, $p=0.033$ ), the trend was towards infections occurring late in pregnancy (questionnaire reported fever [21-40 weeks gestational age], odds ratio 5.05, 95\% confidence interval 2.21-11.54, $\mathrm{p}<$ 0.0005; questionnaire reported other infections [21-40 weeks gestational age], odds ratio 3.98, 95\% confidence interval 2.20-7.22, $\mathrm{p}<0.0005$; questionnaire reported labour and delivery complicated by infection, odds ratio $2.95,95 \%$ confidence interval $1.65-5.26, p<0.0005$ ). 
Table 1

Maternal infection during pregnancy and cerebral palsy

\begin{tabular}{|c|c|c|c|}
\hline Test & Odds Ratio (95\% Cl) & $P$ value & $\begin{array}{l}\text { Number of cases (\%)/ } \\
\text { Number of controls (\%) }\end{array}$ \\
\hline Questionnaire reported infection (any) & $1.71(1.39-2.11)$ & $<0.0005$ & $234(39.9) / 322(27.9)$ \\
\hline Perinatal data reported infection (any) & $1.03(0.67-1.60)$ & 0.882 & $32(6.1) / 64(5.9)$ \\
\hline Questionnaire or perinatal data reported infection (any) & $1.55(1.26-1.91)$ & $<0.0005$ & $243(41.4) / 361(31.3)$ \\
\hline Questionnaire reported URIs* (0-20 weeks gestational age) & $1.26(0.90-1.77)$ & 0.184 & $59(10.1) / 94(8.1)$ \\
\hline Questionnaire reported URIs (21-40 weeks gestational age) & $1.13(0.80-1.59)$ & 0.500 & $55(9.4) / 97(8.4)$ \\
\hline Questionnaire reported URIs (within a week after birth) & $1.38(0.52-3.65)$ & 0.513 & $7(1.2) / 10(0.9)$ \\
\hline Questionnaire reported gastro ( $0-20$ weeks gestational age) & $1.74(0.84-3.59)$ & 0.130 & $14(2.4) / 16(1.4)$ \\
\hline Questionnaire reported gastro (21-40 weeks gestational age) & $1.41(0.81-2.46)$ & 0.223 & $22(3.7) / 31(2.7)$ \\
\hline Questionnaire reported gastro (within a week after birth) & $1.97(0.28-14.02)$ & $\begin{array}{l}0.607 \text { (Fischer's exact } \\
\text { test) }\end{array}$ & $2(0.3) / 2(0.2)$ \\
\hline Questionnaire reported herpes (0-20 weeks gestational age) & $2.00(1.01-3.94)$ & 0.043 & $17(2.9) / 17(1.5)$ \\
\hline Questionnaire reported herpes (21-40 weeks gestational age) & $1.07(0.53-2.19)$ & 0.844 & $12(2.0) / 22(1.9)$ \\
\hline Questionnaire reported herpes (within a week after birth) & $1.54(0.57-4.14)$ & 0.394 & $7(1.2) / 9(0.8)$ \\
\hline Questionnaire reported fever (0-20 weeks gestational age) & $1.61(0.77-3.37)$ & 0.202 & $13(2.2) / 16(1.4)$ \\
\hline Questionnaire reported fever (21-40 weeks gestational age) & $5.05(2.21-11.54)$ & $<0.0005$ & $20(3.4 \%) / 8(0.7 \%)$ \\
\hline Questionnaire reported fever (within a week after birth) & $0.84(0.32-2.20)$ & 0.724 & $6(1.0) / 14(1.2)$ \\
\hline $\begin{array}{l}\text { Questionnaire reported other infections }{ }^{\dagger}(0-20 \text { weeks } \\
\text { gestational age) }\end{array}$ & $2.13(1.04-4.33)$ & 0.033 & $16(2.7) / 15(1.3)$ \\
\hline $\begin{array}{l}\text { Questionnaire reported other infections ( } 21-40 \text { weeks } \\
\text { gestational age) }\end{array}$ & $3.98(2.20-7.22)$ & $<0.0005$ & $33(5.6) / 17(1.5)$ \\
\hline $\begin{array}{l}\text { Questionnaire reported other infections (within a week after } \\
\text { birth) }\end{array}$ & $1.47(0.82-2.65)$ & 0.194 & $20(3.4) / 27(2.3)$ \\
\hline $\begin{array}{l}\text { Questionnaire reported labour and delivery complicated by } \\
\text { infection }\end{array}$ & $2.95(1.65-5.26)$ & $<0.0005$ & 29 (4.9) / 20 (1.7) \\
\hline Questionnaire reported urinary tract infection & $1.53(0.91-2.57)$ & 0.109 & $26(4.4) / 34(2.9)$ \\
\hline
\end{tabular}

* URIs Upper respiratory tract infections

† Other infections included cytomegalovirus, Ross River virus, chicken pox, staphylococcus, streptococcus, cystitis, wound infections and urinary tract infection 


\section{Chapter 6}

\section{Epidemiology}

\section{Small for gestational age (using customised centiles)}

Small for gestational age calculated using customised birth weight for gestational age ranges was significantly associated with cerebral palsy (Gardosi J, Francis A. Customised Weight Centile Calculator - GROW-Centile v6.4 2009; Gestation Network; www.gestation.net; v6.4; see Table 2). Infants with birth weight below the $3 \mathrm{rd}$, 5th, 10th or 40th centile were more likely to have cerebral palsy than those with birth weight in the 40th-60th centiles (below 3rd: odds ratio $11.75,95 \%$ confidence interval $6.25-22.08, p<0.0005$, 5th: odds ratio $8.3395 \%$ confidence interval 4.94-14.05, $p<0.0005 ; 10^{\text {th }}$ odds ratio $4.35,95 \%$ confidence interval $2.92-6.48, p<0.0005$; $40^{\text {th }}$ odds ratio $2.02,95 \%$ confidence interval $\left.1.50-2.73, p<0.0005\right)$. Infants with birth weight between the $10^{\text {th }}$ and $19^{\text {th }}$ centiles were also more likely to have cerebral palsy (odds ratio 1.67 , $95 \%$ confidence interval $1.09-2.54, p=0.017$ ) as were those with birth weight between the $30^{\text {th }}$ and $39^{\text {th }}$ centile (odds ratio $1.52,95 \%$ confidence interval $1.02-2.28, p=0.041$ ) and all those with birth weight below the $40^{\text {th }}$ centile (odds ratio $2.02,95 \%$ confidence interval $1.50-2.73, p=0.0005$ ) when compared to those with birth weight between the $40^{\text {th }}$ and $60^{\text {th }}$ centiles. There was no significant association between cerebral palsy birth weight between the $20^{\text {th }}$ and $29^{\text {th }}$ centile or above the $60^{\text {th }}$ or $90^{\text {th }}$ centiles when compared to those with birth weight between the $40^{\text {th }}$ and $60^{\text {th }}$ centiles. 
Chapter 6

Epidemiology

Table 2

Small for gestational age and cerebral palsy

\begin{tabular}{|l|l|l|l|}
\hline Test & Odds Ratio (95\% CI) & P value & Number of cases (\%)/ Number of controls (\%) \\
\hline$<3$ rd centile vs $40-60^{\text {th }}$ centile* & $11.75(6.25-22.08)$ & $<0.0005$ & $65(43.9) / 14(6.3)$ \\
\hline$<5^{\text {th }}$ centile vs $40-60^{\text {th }}$ centile & $8.33(4.94-14.05)$ & $<0.0005$ & $79(48.8) / 24(10.3)$ \\
\hline$<10^{\text {th }}$ centile vs $40-60^{\text {th }}$ centile & $4.35(2.92-6.48)$ & $<0.0005$ & $110(57.0) / 64(23.4)$ \\
\hline $10-19^{\text {th }}$ centile vs $40-60^{\text {th }}$ centile & $1.67(1.09-2.54)$ & 0.017 & $56(40.3) / 85(28.8)$ \\
\hline $20-29^{\text {th }}$ centile vs $40-60^{\text {th }}$ centile & $1.27(0.81-1397)$ & 0.297 & $44(34.6) / 88(29.5)$ \\
\hline $30-39^{\text {th }}$ centile vs $40-60^{\text {th }}$ centile & $1.52(1.02-2.28)$ & 0.041 & $62(42.8) / 103(32.9)$ \\
\hline$<40^{\text {th }}$ centile vs $40-60^{\text {th }}$ centile & $2.02(1.50-2.73)$ & $<0.0005$ & $272(76.6) / 340(61.8)$ \\
\hline$>60^{\text {th }}$ centile vs $40-60^{\text {th }}$ centile & $0.93(0.68-1.26)$ & 0.635 & $175(67.8) / 477(69.4)$ \\
\hline$>90^{\text {th }}$ centile vs $40-60^{\text {th }}$ centile & $1.41(0.78-1.67)$ & 0.497 & $69(45.4) / 153(42.1)$ \\
\hline
\end{tabular}

*centiles were calculated using the GROW centile calculator (Gardosi J, Francis A. Customised Weight Centile Calculator - GROW-Centile v6.4 2009; Gestation Network; www.gestation.net; v6.4) 


\section{Chapter $6 \quad$ Epidemiology}

\section{Gestational age}

Early gestational age was significantly associated with cerebral palsy outcome (Table 3). Infant gestational age of less than 32 weeks or 36 weeks presented a significant risk when compared to all other gestational ages and also when compared to term born infants ( $<32$ weeks gestational age, odds ratio $70.62,95 \%$ confidence interval 34.38-145.04, $p<0.0005 ; 32-36$ weeks gestational age 5.02, 95\% confidence interval 3.49-7.21, $p<0.0005$ )

\section{Table 3}

Gestational age and cerebral palsy

\begin{tabular}{|l|l|l|l|}
\hline Test & Odds Ratio $(95 \% \mathrm{Cl})$ & P value & $\begin{array}{l}\text { Number of cases (\%)/ Number of } \\
\text { controls (\%) }\end{array}$ \\
\hline$<32$ weeks gestational age vs all other gestational ages & $59.20(28.87-121.38)$ & $<0.0005$ & $170(29.3) / 8(0.7)$ \\
\hline$<32$ weeks gestational age vs $>36$ weeks gestational age & $70.62(34.38-145.04)$ & $<0.0005$ & $170(34.1) / 8(0.7)$ \\
\hline $32-36$ weeks gestational age vs all other gestational ages & $3.33(2.33-4.75)$ & $<0.0005$ & $83(14.3) / 55(4.8)$ \\
\hline $32-36$ weeks gestational age vs $>36$ weeks gestational age & $5.02(3.49-7.21)$ & $<0.0005$ & $83(20.2) / 55(4.8)$ \\
\hline
\end{tabular}




\section{Chapter $6 \quad$ Epidemiology}

\section{Multiple birth}

Multiple births were significantly associated with cerebral palsy outcome (see Table 4, twins versus singletons, odds ratio $6.62,95 \%$ confidence interval $4.00-10.95, p<0.0005)$. Only one triplet pregnancy was reported in this study and while this was a cerebral palsy case there is insufficient data to draw any conclusions.

Table 4

Multiple birth and cerebral palsy

\begin{tabular}{|l|l|l|l|}
\hline Test & Odds Ratio (95\% CI) & P value & Number of cases (\%)/ Number of controls (\%) \\
\hline Twins vs singletons & $6.62(4.00-10.94)$ & $<0.0005$ & $64(10.9) / 21(1.8)$ \\
\hline Triplets vs singletons & - & - & $1(0.02) / 0(0)$ \\
\hline
\end{tabular}




\section{Siblings or parents with cerebral palsy}

Children with a relation who had cerebral palsy were more likely to have cerebral palsy themselves (see Table 5). Having a sibling with cerebral palsy was not a significant risk for cerebral palsy. There was insufficient data to conclude that a parent with cerebral palsy is a risk factor for their child developing the condition, however all examples in this cohort were cases. More distant family members with cerebral palsy was a risk for cerebral palsy as was any relation with cerebral palsy (odds ratio $1.65,95 \%$ confidence interval $1.16-2.35, p=0.005$ and odds ratio $1.61,95 \%$ confidence interval $1.12-2.32, p=0.010$ respectively).

\section{Table 5}

Siblings or parents with cerebral palsy and the risk of cerebral palsy

\begin{tabular}{|l|l|l|l|}
\hline Test & Odds Ratio (95\% Cl) & P value & Number of cases (\%)/Number of controls (\%) \\
\hline $\begin{array}{l}\text { Sibling with cerebral palsy vs } \\
\text { sibling without }\end{array}$ & $3.96(0.99-15.9)$ & $\begin{array}{l}0.069 \text { (Fischer's } \\
\text { exact test) }\end{array}$ & $6(1.0) / 3(0.3)$ \\
\hline $\begin{array}{l}\text { Mother with cerebral palsy vs } \\
\text { mother without }\end{array}$ & - & - & $2(0.3) / 0(0)$ \\
\hline $\begin{array}{l}\text { Father with cerebral palsy vs } \\
\text { father without }\end{array}$ & - & - & $3(0.5) / 0(0)$ \\
\hline $\begin{array}{l}\text { Other family member* with } \\
\text { cerebral palsy vs other family } \\
\text { members without }\end{array}$ & $1.65(1.16-2.35)$ & 0.005 & $62(10.6) / 77(6.7)$ \\
\hline $\begin{array}{l}\text { Any relationt with cerebral palsy } \\
\text { vs any relation without }\end{array}$ & $1.61(1.12-2.32)$ & 0.010 & $56(9.5) / 71(6.2) \_$ \\
\hline
\end{tabular}

* other family members were considered as more distant than a parent or sibling

tincludes a sibling, parent or more distant relation 


\section{Breech presentation}

Breech presentation at the time of delivery was significantly associated with cerebral palsy when compared to cephalic presentation (odds ratio $2.48,95 \%$ confidence interval 1.76 3.49, $p<0.0005$; see Table 6). For infants presenting breech, vaginal delivery and emergency Caesarean delivery was also associated with cerebral palsy (odds ratio $8.36,95 \%$ confidence interval 3.30-21.19, $\mathrm{p}<0.0005$ and odds ratio $4.48,95 \%$ confidence interval $2.62-7.65, p<0.0005$ ), while elective Caesarean delivery was not when compared to spontaneous cephalic vaginal delivery.

\section{Table 6}

Breech presentation and cerebral palsy

\begin{tabular}{|l|l|l|l|}
\hline Test & Odds Ratio (95\% CI) & P value & Number of cases (\%)/Number of controls (\%) \\
\hline Breech vs cephalic & $2.48(1.76-3.49)$ & $<0.0005$ & $77(13.7) / 69(6.0)$ \\
\hline $\begin{array}{l}\text { Vaginal breech vs spontaneous } \\
\text { cephalic vaginal }\end{array}$ & $8.36(3.30-21.19)$ & $<0.0005$ & $19(7.1) / 6(0.9)$ \\
\hline $\begin{array}{l}\text { Emergency Caesarean breech vs } \\
\text { spontaneous cephalic vaginal }\end{array}$ & $4.48(2.62-7.65)$ & $<0.0005$ & $39(13.6) / 23(3.4)$ \\
\hline $\begin{array}{l}\text { Elective Caesarean breech vs } \\
\text { spontaneous cephalic vaginal }\end{array}$ & $1.32(0.75-2.34)$ & 0.337 & $19(7.1) / 38(5.5)$ \\
\hline
\end{tabular}




\section{Chapter $6 \quad$ Epidemiology}

\section{"Disappearing twin" on ultrasound}

"Disappearing twin" was considered to be present when a multiple pregnancy was reported at the first trimester ultrasound and only a singleton delivery was reported subsequently. Only ten such cases were reported and while association was not observed, it cannot be excluded (see Table 7).

\section{Table 7}

"Disappearing twin" and cerebral palsy

\begin{tabular}{|l|l|l|l|}
\hline Test & Odds Ratio (95\% Cl) & P value & Number of cases (\%)/Number of controls (\%) \\
\hline $\begin{array}{l}\text { Disappearing twin on ultrasound } \\
\text { *vs singleton }\end{array}$ & $1.98(0.82-4.79)$ & 0.121 & $10(1.7) / 10(0.9)$ \\
\hline
\end{tabular}

* when a multiple pregnancy was reported at the first trimester ultrasound and only a singleton delivery reported subsequently. 


\section{Chapter $6 \quad$ Epidemiology}

\section{Use of heat in labour}

Data about use of heat in labour including hot packs, hot showers or hot baths given in labour was collected by maternal questionnaire. There was an inverse relationship between heat in labour and cerebral palsy outcome (Table 8 , odds ratio $0.47,95 \%$ confidence interval 0.36 $0.61, p<0.0005)$.

\section{Table 8}

Heat in labour and cerebral palsy

\begin{tabular}{|l|l|l|l|}
\hline Test & Odds Ratio (95\% CI) & P value & Number of cases (\%)/Number of controls (\%) \\
\hline $\begin{array}{l}\text { Hot packs, showers or baths } \\
\text { during birth }\end{array}$ & $0.47(0.36-0.61)$ & $<0.0005$ & $90(16.2) / 320(29.3)$ \\
\hline
\end{tabular}




\section{Chapter $6 \quad$ Epidemiology}

\section{Bleeding at any time in pregnancy}

Bleeding at any time in pregnancy was significantly associated with cerebral palsy (odds ratio $2.04,95 \%$ confidence interval $1.61-2.58, \mathrm{p}<0.0005$ ) (see Table 10 ).

Table 10

Bleeding at any time in pregnancy and cerebral palsy

\begin{tabular}{|l|l|l|l|}
\hline Test & Odds Ratio $(\mathbf{9 5 \%} \mathrm{Cl})$ & P value & Number of cases (\%)/Number of controls (\%) \\
\hline $\begin{array}{l}\text { Bleeding at any time in } \\
\text { pregnancy }\end{array}$ & $2.04(1.61-2.58)$ & $<0.0005$ & $172(29.3) / 195(16.9)$ \\
\hline
\end{tabular}




\section{Chapter $6 \quad$ Epidemiology}

\section{Diabetes}

Diabetes (including gestational diabetes and pre-existing maternal diabetes) was not significantly associated with cerebral palsy outcome (see Table 10.)

Table 10

Diabetes and cerebral palsy

\begin{tabular}{|l|l|l|l|}
\hline Test & Odds Ratio (95\% Cl) & P value & Number of cases (\%)/Number of controls (\%) \\
\hline Diabetes & $1.50(0.95-2.39)$ & 0.083 & $33(5.6) / 44(3.8)$ \\
\hline
\end{tabular}




\section{Maternal body mass index (BMI)}

Maternal BMI was not significantly associated with cerebral palsy when comparing underweight $(\mathrm{BMI}<18.5)$, overweight $(\mathrm{BMI} 25-30)$ or obese $(\mathrm{BMI}>30)$ categories with mothers in the normal range (BMI 18.5-25) (see Table 11).

\section{Table 11}

Maternal body mass index (BMI) and cerebral palsy

\begin{tabular}{|l|l|l|l|}
\hline Test & Odds Ratio (95\% Cl) & P value & Number of cases (\%)/Number of controls (\%) \\
\hline Underweight vs normal BMI* & $0.79(0.55-1.13)$ & 0.203 & $50(14.0) / 118(17.0)$ \\
\hline Overweight vs normal BMI & $1.00(0.78-1.29)$ & 0.992 & $136(30.6) / 254(30.6)$ \\
\hline Obese vs normal BMI & $0.92(0.68-1.24)$ & 0.577 & $80(20.6) / 163(22.1)$ \\
\hline
\end{tabular}

*BMI $<18.5=$ =underweight, 18.5-25=normal, 25-30=overweight, $>30=$ obese 


\section{Chapter $6 \quad$ Epidemiology}

\section{Pregnancy hypertension}

Maternal hypertension, including both pre-existing hypertension and gestational hypertension was not significantly associated with cerebral palsy outcome (see Table 12).

\section{Table 12}

Hypertension and cerebral palsy

\begin{tabular}{|l|l|l|l|}
\hline Test & Odds Ratio (95\% Cl) & P value & Number of cases (\%)/Number of controls (\%) \\
\hline Hypertension* & $1.19(0.90-1.58)$ & 0.218 & $90(15.3) / 152(13.2)$ \\
\hline
\end{tabular}

* including both pre-existing hypertension and gestational hypertension 


\section{Chapter $6 \quad$ Epidemiology}

\section{Nuchal cord or cord entanglement}

Nuchal cord or umbilical cord entanglement at birth was significantly associated with cerebral palsy outcome (odds ratio 1.86, 95\% confidence interval 1.28-2.71, $\mathrm{p}=0.001$; see Table 13).

\section{Table 13}

Nuchal cord or cord entanglement and cerebral palsy

\begin{tabular}{|l|l|l|l|}
\hline Test & Odds Ratio (95\% Cl) & P value & Number of cases (\%)/Number of controls (\%) \\
\hline Nuchal cord or entanglement & $1.86(1.28-2.71)$ & 0.001 & $56(9.5) / 62(5.4)$ \\
\hline
\end{tabular}




\section{Smoking, alcohol consumption and illicit drug use}

Maternal alcohol consumption was not significantly associated with cerebral palsy outcome for the three categories collected (1-2 drinks per week, 3-4 drinks per week or $>4$ drinks per week compared to $<1$ drink per week). Illicit drug use of any kind was significantly associated with cerebral palsy outcome (odds ratio $2.22,95 \%$ confidence interval 1.14-4.30, $p=0.016$ ), as was tobacco smoking (odds ratio $1.37,95 \%$ confidence interval $1.02-1.85, \mathrm{p}=0.037$ ). This data is summarised in Table 14.

\section{Table 14}

Smoking, alcohol and illicit drug use and cerebral palsy

\begin{tabular}{|l|l|l|l|}
\hline Test & Odds Ratio (95\% CI) & P value & Number of cases (\%)/Number of controls (\%) \\
\hline $\begin{array}{l}\text { 1-2 drinks per week vs }<1 \text { drink } \\
\text { per week }\end{array}$ & $0.88(0.62-1.24)$ & 0.461 & $50(8.8) / 111(9.9)$ \\
\hline $\begin{array}{l}\text { 3-4 drinks per week vs <1 drink } \\
\text { per week }\end{array}$ & $0.86(0.42-1.75)$ & 0.671 & $11(2.1) / 25(2.4)$ \\
\hline $\begin{array}{l}>4 \text { drinks per week vs }<1 \text { drink } \\
\text { per week }\end{array}$ & $0.32(0.04-2.70)$ & 0.434 (Fischer's exact test) & $1(0.2) / 6(0.6)$ \\
\hline Drug use vs no drug use & $2.22(1.14-4.30)$ & 0.016 & $19(3.3) / 17(1.5)$ \\
\hline Smoking vs non-smoking & $1.37(1.02-1.85)$ & 0.037 & $82(14.0) / 122(10.6)$ \\
\hline
\end{tabular}




\section{Chapter $6 \quad$ Epidemiology}

\section{Anaemia}

Maternal anaemia during pregnancy was not significantly associated with cerebral palsy (see Table 15).

Table 15

Anaemia and cerebral palsy

\begin{tabular}{|l|l|l|l|}
\hline Test & Odds Ratio (95\% Cl) & P value & Number of cases (\%)/Number of controls (\%) \\
\hline Anaemia & $0.84(0.60-1.18)$ & 0.314 & $54(9.2) / 124(10.7)$ \\
\hline
\end{tabular}


Chapter 6

Epidemiology

\section{Maternal hypothyroidism}

Maternal hypothyroidism was not significantly associated with cerebral palsy but only 18 cases were reported (see Table 16).

Table 16

Maternal hypothyroidism and cerebral palsy

\begin{tabular}{|l|l|l|l|}
\hline Test & Odds Ratio $(95 \% \mathrm{CI})$ & P value & Number of cases (\%)/Number of controls (\%) \\
\hline Maternal hypothyroidism & $0.98(0.37-2.63)$ & 0.972 & $6(1.0) / 12(1.0)$ \\
\hline
\end{tabular}




\section{Chapter $6 \quad$ Epidemiology}

\section{Other risk factors}

A number of other obstetric risk factors which were not specified a priori in the protocol (chapter 2) were examined in relation to cerebral palsy outcome. Apgar score at one minute of less than four was significantly associated with cerebral palsy when compared to a score over eight (Table 17, odds ratio 20.27, 95\% confidence interval 11.29-36.42, $p<0.0005$ ) and Apgar score at five minutes showed the same trend but with insufficient numbers to confirm an association (odds ratio 51.27, 95\% confidence interval 12.20-215.47, Fischer's exact test $\mathrm{p}<0.0005)$. Fisher's exact test was used in this case because cell sizes were small. Males were more likely to have cerebral palsy than females (odds ratio $1.68,95 \%$ confidence interval 1.38 2.06, $\mathrm{p}<0.0005)$ and emergency and elective Caesarean were both a risk when compared to spontaneous vaginal delivery (odds ratio $2.42,95 \%$ confidence interval 1.88-3.12, $p<0.0005$ and odds ratio $1.39,95 \%$ confidence interval $1.00-1.94, p=0.050$, respectively). Forceps delivery, vacuum delivery and maternal age were not associated with cerebral palsy. Mothers who reported having three or more miscarriages previously were more likely to deliver a child with cerebral palsy when compared to mothers who had no history of miscarriage (odds ratio 2.30, 95\% confidence interval 1.38-3.82, $\mathrm{p}=0.001$ ). 
Chapter 6

Epidemiology

Table 17

Other obstetric factors and cerebral palsy

\begin{tabular}{|c|c|c|c|}
\hline Test & Odds Ratio (95\% Cl) & $P$ value & Number of cases (\%)/Number of controls (\%) \\
\hline $\begin{array}{l}\text { Apgar score at } 1 \text { minute }<4 \\
\text { compared to }>8\end{array}$ & $20.27(11.29-36.42)$ & $<0.0005$ & 65 (38.2) / $16(3.0)$ \\
\hline $\begin{array}{l}\text { Apgar score at } 5 \text { minutes }<4 \\
\text { compared to }>8\end{array}$ & $51.27(12.20-215.47)$ & $\begin{array}{l}<0.0005 \text { (Fischer's } \\
\text { exact) }\end{array}$ & $31(9.5) / 2(0.2)$ \\
\hline Male vs female gender & $1.68(1.38-2.06)$ & $<0.0005$ & $345(58.8)$ / 529 (45.8) \\
\hline $\begin{array}{l}\text { Emergency Caesarean vs } \\
\text { spontaneous }\end{array}$ & $2.42(1.88-3.12)$ & $<0.0005$ & $175(41.1) / 189(22.3)$ \\
\hline $\begin{array}{l}\text { Elective Caesarean vs } \\
\text { spontaneous }\end{array}$ & $1.39(1.00-1.94)$ & 0.050 & 66 (20.8) / 124 (15.9) \\
\hline Forceps vs spontaneous & $1.27(0.86-1.87)$ & 0.240 & $43(14.6) / 89$ (11.9) \\
\hline Vacuum vs spontaneous & $0.84(0.51-1.38)$ & 0.479 & $22(8.1) / 69(9.5)$ \\
\hline $\begin{array}{l}\text { Instrumental (type not stated) vs } \\
\text { spontaneous }\end{array}$ & $1.01(0.36-2.85)$ & 0.990 & $5(2.0) / 13(1.9)$ \\
\hline Maternal age $<20$ vs $25-35$ & $0.96(0.43-2.15)$ & 0.913 & $9(2.1) / 18(2.2)$ \\
\hline Maternal age $<25$ vs $25-35$ & $0.92(0.65-1.28)$ & 0.608 & 57 (12.0) / 119 (12.9) \\
\hline Maternal age $>35$ vs $25-35$ & $0.92(0.71-1.19)$ & 0.514 & $110(20.8) / 229(22.2)$ \\
\hline Maternal age $>40$ vs $25-35$ & $1.20(0.70-2.08)$ & 0.509 & $22(5.0) / 35(4.2)$ \\
\hline Any miscarriage vs none & $1.25(1.00-1.57)$ & 0.053 & $168(29.8) / 281(25.4)$ \\
\hline 1 or 2 miscarriages vs none & $1.12(0.88-1.43)$ & 0.344 & $135(25.5) / 251(23.3)$ \\
\hline 3 or more miscarriages vs none & $2.30(1.38-3.82)$ & 0.001 & $33(7.7) / 30(3.5)$ \\
\hline
\end{tabular}




\section{Discussion}

\section{Maternal infection during pregnancy}

Maternal infection has previously been reported as a risk factor for cerebral palsy ${ }^{110} 111$ along with more specific associations such as chorioamnonitis ${ }^{114}$ and neurotropic viral infection

${ }^{94}$. This is the first study to investigate infection using a maternal health questionnaire that seeks information about upper respiratory tract, gastrointestinal and herpes infections, and fever from the beginning of pregnancy through to one week after delivery. Information was also gathered about urinary tract infections and labour and delivery complicated by infection; this information was supplemented by data from perinatal databases. Upper respiratory tract, gastrointestinal or herpes virus infections may not be considered clinically important and are likely to have been under reported in previous studies which used information from clinical databases. Diarrhoea and coughs have been associated with epilepsy ${ }^{115}$ but this is the first investigation in relation to cerebral palsy. Our data did not provide evidence for association of upper respiratory tract infections or gastrointestinal infections with cerebral palsy. However, reported herpes infection, likely to be cold sores or genital herpes, was significantly associated with cerebral palsy when present before 20 weeks gestational age. Herpes viruses have previously been associated with cerebral palsy; however the data was taken from fetal DNA extracted from Guthrie cards and indicates viral infection at 37-40 weeks gestational age ${ }^{94}$.

In this study, the most significant associations were found in the 21-40 weeks gestational age range and included fever, labour and delivery complicated by infection and other infections (other infections included cytomegalovirus, Ross River virus, chicken pox, staphylococcus, streptococcus, cystitis, wound infections and urinary tract infection). The data support the hypothesis that severe infections late in pregnancy are more likely to be associated with cerebral palsy than infections early in pregnancy and of a mild or subclinical nature. Upper respiratory tract infections and gastroenteritis, which are common and often of concern to pregnant women, 


\section{Chapter 6}

\section{Epidemiology}

were not significantly associated with an increased risk of cerebral palsy. Data sourced from the maternal questionnaire may be influenced by recall bias and these results require replication, preferably prospectively, before clinical practice recommendations can be considered.

\section{Small for gestational age (using customised centiles)}

Small for gestational age has previously been associated with cerebral palsy ${ }^{116} 30117$. This present study used customised birth weight centiles which better define intrauterine growth restriction by adjusting for infant birth weight, gestational age, gender, ethnicity, maternal height and weight at the time of first obstetric booking and parity based on the Australian population. Significant associations were seen between low centiles, a proxy marker for intrauterine growth restriction, and cerebral palsy. No associations were seen with high centiles as has been previously reported ${ }^{118}$. Inappropriate growth in utero may be a cause or consequence of abnormal brain development but retrospective case control studies cannot determine which of these possibilities is more likely. Unfortunately length at birth is not recorded in perinatal data bases and therefore the Ponderal index cannot be calculated as a measure of late intrauterine growth restriction ${ }^{119} 120$.

\section{Gestational age}

Gestational age has previously been associated with cerebral palsy and is the strongest risk factor for cerebral palsy reported to date ${ }^{109}$. Our results support this association with an odds ratio of 70.6 (95\% confidence interval 34.38-145.04) reported for births less than 32 weeks gestational age when compared to term born controls.

\section{Multiple births}

Association of multiple birth and cerebral palsy was observed as early as $1955^{121}$ and the association has been demonstrated in this study. Cerebral palsy has also been noted in triplets and quadruplets ${ }^{112}$ but there was insufficient data to draw any conclusions relating to these births. There was one triplet pregnancy in the cohort and this did relate to a case; there were no 


\section{Chapter $6 \quad$ Epidemiology}

quadruplets. The mechanism by which multiple birth increases cerebral palsy risk is difficult to define as multiple birth is strongly associated with preterm delivery, intrauterine growth restriction and other obstetric complications, all of which contribute to cerebral palsy outcome.

\section{Siblings or parents with cerebral palsy}

Familial aggregations of cerebral palsy have been reported previously with the odds ratio of siblings having cerebral palsy being 4.82 for singletons and 29.02 for twins ${ }^{11}$. We were unable to confirm this significant association, probably due to the low incidence of siblings with cerebral palsy (1\%), although the odds ratio was similar (3.96, 95\% confidence interval 0.99-15.9). While this is lower than the data presented by Hemminki et al, selection bias in our prospective study may have increased the number of control families volunteering participation who have an affected relative or where a sibling was unable to participate because of the age criteria. Parents with cerebral palsy were only noted amongst the case cohort and not in control families, although the low frequency prevents any conclusions from being drawn. The familial aggregations of cerebral palsy that we have identified suggest the possibility of a genetic component in the aetiology of cerebral palsy, although an environmental risk common to the family cannot be excluded. Half a percent of cerebral palsy cases are the direct result of known genetic anomalies ${ }^{122}$ and although this work has not shown a strong genetic susceptibility to cerebral palsy, alternative approaches focusing only on cases from a familial cluster may reveal other causal mutations associated with cerebral palsy, possibly unique to each family.

\section{Breech position}

The literature is controversial relating to the association of breech position and cerebral palsy outcome ${ }^{123} 124$. Our report confirms a significant association between breech position and cerebral palsy. Our data suggests that this risk is potentiated by vaginal delivery or emergency Caesarean delivery and corroborates the literature ${ }^{123}$. Our data did not support an association of breech presentation with elective Caesarean and cerebral palsy although the number of cases is small and replication is required before clinical practice recommendations could be made. 


\section{"Disappearing twin" on ultrasound}

"Disappearing twin" as a risk factor for cerebral palsy has been reported previously, however the number of cases reported is small. Newton et al ${ }^{125}$ observed a vanishing twin, as reported on obstetric ultrasound conducted before 12 weeks gestation, in 1 of 9 case mothers and 1 of 23 control mothers. Taylor et $a{ }^{126}$ report a similar trend with 9 cases and 4 controls after fetal demise before 20 weeks gestation and 10 cases and 3 controls after demise past 20 weeks pregnancy. Our study examined fetal demise in the first trimester (12 weeks) and shows a similar trend. Our sample size was comparable to the previously reported studies with 10 cases and 10 controls reporting fetal demise in the first trimester (odds ratio 1.98, confidence interval 0.87-4.79) and although prospectively recruited, our cohort is unlikely to be biased in regard to this factor. The studies to date have all been underpowered but since they have all been performed in independent cohorts and report a common trend, it is possible that a disappearing twin does contribute to cerebral palsy. Given that disappearing twin is uncommon, it is unlikely that this conclusion, and the mechanism of association or causation, will be clarified in the near future.

\section{Use of heat in labour}

Use of heat in labour and cerebral palsy outcome in infants has not been investigated to date. Intrapartum pyrexia has been described as an independent risk factor for cerebral palsy ${ }^{127}$. An aim of this study was to investigate if iatrogenic heat applied during labour increased cerebral palsy risk. Furthermore, head cooling of neonates with encephalopathy has been investigated in 5 trials with meta-analysis suggesting a benefit to survivors ${ }^{128}$. Since head cooling appears to have neuroprotective properties, this study set out to investigate if application of heat by the common obstetric practise of taking hot baths, hot showers or using hot packs in labour contributed to the risk of cerebral palsy. Our results do not support a causal role but shows an inverse relation to cerebral palsy outcome. Potentially this association may be the result of confounding, as women who have uncomplicated pregnancies are more likely to be offered hot 


\section{Chapter $6 \quad$ Epidemiology}

packs, baths or showers during labour than those with obstetric risk factors for cerebral palsy such as preterm labour or small for dates baby. Future studies are needed to examine in more detail the type of heat applied along with effect on maternal temperature, length of application and other confounders. More evidence is required before recommendations about this common clinical practice can be made.

\section{Bleeding at any time in pregnancy}

Ante-partum haemorrhage has previously been associated with an increased risk of cerebral palsy ${ }^{129} 109$, while others did not report an association ${ }^{130}{ }^{131}$. Our study considered bleeding in the first trimester up until the time of delivery and supported this association (odds ratio $2.04,95 \%$ confidence interval $1.61-2.58, \mathrm{p}<0.0005)$.

\section{Diabetes}

Gilbert et al report an association between cerebral palsy and gestational diabetes in some gestational age subgroups but not for pre-existing diabetes ${ }^{111}$. Our data did not support an association and we were unable to distinguish between pre-existing and gestational diabetes using the data collected.

\section{Maternal body mass index (BMI)}

One previous study has investigated BMI as a risk factor for cerebral palsy ${ }^{132}$. Low BMI is associated with adverse pregnancy outcomes such as preterm birth ${ }^{133}$ and this in turn is associated with cerebral palsy. Our data do not support an association of BMI with cerebral palsy, perhaps because the contribution to preterm birth is minor (odds ratio 1.05, 95\% confidence interval $1.00-1.10, p=0.045$ ); larger numbers would be required to observe any statistically significant change.

\section{Pregnancy hypertension}

Pregnancy hypertension has been reported to be a risk factor for cerebral palsy ${ }^{31}$ but other studies have not supported the link ${ }^{124}$, whether considering pre-existing hypertension or 
gestational hypertension and taking into account gestational age ${ }^{111}$. Our study does not support an association of hypertension (pre-existing or gestational) with cerebral palsy.

\section{Nuchal cord or cord entanglement}

Our study used data from the maternal questionnaire as well as perinatal databases to examine a composite of cord prolapse, nuchal cord and cord entanglement. Nelson et al described an 18 fold increase in spastic cerebral palsy when nuchal cord was described as tight or entangled ${ }^{134}$. Our data could not distinguish between tight and loose nuchal cord. Cord prolapse has been associated with cerebral palsy in previous studies ${ }^{111}$. Cord prolapse is a cause of hypoxia, which may lead to cerebral palsy, although cord gas blood and $\mathrm{pH}$ levels are required to establish a causal link ${ }^{135}$.

\section{Smoking, alcohol consumption and illicit drug use}

Smoking, alcohol use and illicit drug use during pregnancy have all been previously reported as risk factors for cerebral palsy ${ }^{132} 31136109$. Our study was able to confirm associations with smoking and illicit drug use but not alcohol although reporting bias is likely to influence the data analysed for these measures. These risk factors, while moderate, are modifiable and may present an avenue for cerebral palsy prevention in the future.

\section{Anaemia}

Anaemia in the second half of pregnancy has previously been reported as inversely related to cerebral palsy ${ }^{137}$. Our study did not classify the time of anaemia during pregnancy and was unable to replicate this result.

\section{Maternal hypothyroidism}

Maternal hypothyroidism has previously been associated with cerebral palsy and these studies have recently been reviewed by Hong et $a^{138}$. We could not replicate an association with cerebral palsy. The data we used to attribute hypothyroidism was based upon maternal report of medical conditions, thyroxin use during pregnancy and indication of the thyroid disorder in 


\section{Chapter 6}

perinatal databases. No data was collected about hormone blood levels, severity, dietary iodine intake and timing of diagnosis and treatment that may to be of importance.

\section{Other risk factors}

Apgar score at one minute has been associated with cerebral palsy ${ }^{139}$ and our study confirms a strong association. Low Apgar scores at five minutes have also previously been associated with cerebral palsy ${ }^{140}$. Our study confirms this association, however our numbers were small for this measure. Male gender has also been associated with cerebral palsy and this is confirmed in our cohort ${ }^{141}$, possibly suggesting an X-linked contribution to cerebral palsy. Previous studies did not associate advanced maternal age with cerebral palsy ${ }^{113}$ and this is confirmed by our study. Delivery type has previously been reported to have no association with cerebral palsy ${ }^{131} 124$ and our significant association may be the result of confounding due to other risk factors for cerebral palsy which could also promote Caesarean section likelihood e.g. multiple birth or intrauterine growth restriction. This is the first study to report an association between history of miscarriage and cerebral palsy outcome and requires further confirmation before clinical practice recommendations are made. Previous miscarriage may indicate genetic anomalies ${ }^{142,143}$ or clotting disorders ${ }^{144}$, both of which have been associated with cerebral palsy 12235.

\section{Limitations}

The data in this chapter are based on our maternal questionnaire and perinatal data held by state health departments relating to each pregnancy. The questionnaire and perinatal data sets retrieved are described in chapter 2 and the demographics and quality control of the data described in chapter 3. Comparisons made in chapter 3 suggest that the cohorts in this study are representative of the Australian population but recruitment biases cannot be excluded. Biases can be avoided by conducting population wide studies, but this would preclude the use of a detailed and customised questionnaire and reduce the data available, particularly in relation to antenatal infections. Maternal recall bias may also influence the data collected and could vary 


\section{Chapter $6 \quad$ Epidemiology}

between cases and controls. These limitations are implicit to the case-control methodology and cannot be eliminated.

\section{Conclusions}

This chapter presents data supporting an association between cerebral palsy and maternal infection late in gestation, intrauterine growth restriction, early gestational age, multiple birth, family members with cerebral palsy, breech position, smoking and drug use, low Apgar score, male gender, Caesarean section delivery and previous miscarriages. Upper respiratory tract infections and gastroenteritis during pregnancy, which are common and often a concern to pregnant women, were not associated with a significantly increased risk of cerebral palsy. The use of hot packs, baths or showers during labour was inversely related to cerebral palsy in this cohort. 
Chapter 7 Multivariable Analysis 
Chapter $7 \quad$ Multivariable Analysis

Chapter 7 Multivariable Analysis 
Chapter $7 \quad$ Multivariable Analysis

A Multivariable Model of Cerebral Palsy Prediction Utilising Genetic and Epidemiological Risk Factors*

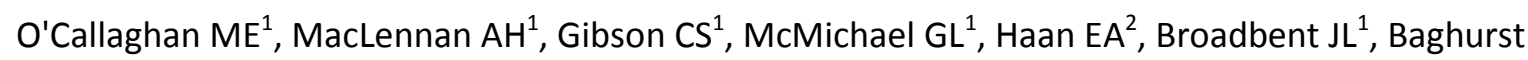
$\mathrm{PA}^{3}$, Goldwater $\mathrm{PN}^{4}$, Dekker $\mathrm{GA}^{1}$, for the Australian Collaborative Cerebral Palsy Research Group. Manuscript in preparation.

${ }^{1}$ Discipline of Obstetrics and Gynaecology, School of Paediatrics and Reproductive Health, The Robinson Institute, University of Adelaide, South Australia.

${ }^{2}$ SA Clinical Genetics Service, SA Pathology at Women's and Children's Hospital and Discipline of Paediatrics, The University of Adelaide, South Australia.

${ }^{3}$ Public Health Research Unit, Women's and Children's Hospital, Children Youth and Women's Health Service, South Australia.

${ }^{4}$ Departments of Microbiology and Infectious Diseases, SA Pathology at Women's and Children's Hospital, South Australia.

* Manuscript in preparation appears in this thesis as Chapter 7 


\section{Chapter $7 \quad$ Multivariable Analysis}

\section{Statement of authorship}

A Multivariable Model of Cerebral Palsy Prediction Utilising Genetic and Epidemiological Risk Factors

Manuscript in preparation.

O'Callaghan ME (Candidate)

Participated in all aspects of this manuscript including the design, laboratory work, ethics submissions, recruitment, data linkage, statistical analysis, interpretation of this study and preparation of the manuscript.

I hereby certify that the statement of contribution is accurate

\section{MacLennan AH}

Principal supervisor, contributed to the study design, data interpretation and manuscript.

I hereby certify that the statement of contribution is accurate 


\section{Chapter $7 \quad$ Multivariable Analysis}

\section{Gibson CS}

Contributed to the study design, data interpretation and manuscript.

I hereby certify that the statement of contribution is accurate

\section{McMichael GL}

Contributed to the laboratory work and manuscript.

I hereby certify that the statement of contribution is accurate

\section{Haan EA}

Co-supervisor, contributed to the study design, data interpretation and manuscript.

I hereby certify that the statement of contribution is accurate 


\section{Chapter $7 \quad$ Multivariable Analysis}

\section{Broadbent J}

Contributed to the ethics submissions, participant recruitment and manuscript.

I hereby certify that the statement of contribution is accurate

\section{Baghurst P}

Contributed to the data analysis, interpretation and manuscript.

I hereby certify that the statement of contribution is accurate

\section{Goldwater PN}

Contributed to the study design, data interpretation and manuscript.

I hereby certify that the statement of contribution is accurate 


\section{Chapter 7 Multivariable Analysis}

\section{Dekker GA}

Co-supervisor, contributed to the study design, data interpretation and manuscript.

I hereby certify that the statement of contribution is accurate

\section{The Australian Collaborative Cerebral Palsy Research Group}

A multidisciplinary group chaired by Professor Alastair MacLennan, who is Head of the Discipline of Obstetrics and Gynaecology in the School of Paediatrics and Reproductive Health at the University of Adelaide. All named authors of this paper are members of the group and wrote the paper on the group's behalf (group listed in acknowledgements). 


\title{
Chapter $7 \quad$ Multivariable Analysis
}

\begin{abstract}
Introduction

This chapter describes a multivariable analysis of 1) genetic variables, 2) epidemiological variables, 3) SNP interactions between mother and child, 4) both mother and child SNP-infection interactions and 5) combinations of all four groups.
\end{abstract}

\section{Methods}

Multiple logistic regression (unconditional) was used to analyse the binary outcome cerebral palsy versus control. Variables found to be associated with cerebral palsy $(p<0.1)$ in the univariable analyses and reported in chapters 4 and 5 were selected for the multivariable analysis. Analysis of cerebral palsy subtypes considered hemiplegia, diplegia, quadriplegia and other cerebral palsy types along with gestational age $<32$ weeks or $>36$ weeks. Analyses also considered ante partum risk factors separately. Odds ratios are reported along with $95 \%$ confidence intervals, sensitivity, specificity and overall prediction.

\section{Results}

Multivariable analyses of epidemiological variables, mother and child genetic variables and the interaction of genetic variables with infection all revealed significant associations with cerebral palsy. Interaction between mother and child genetic variables did not reveal any significant associations. When combining significant factors into a final model, case-control status was correctly identified in $83.4 \%$ of the cohort with sensitivity (case prediction) of $45.0 \%$ and specificity (control prediction) of 96.8\%. Factors remaining significant were Apgar score (one minute) $<4$ ( $p<0.0005$, odds ratio $14.3,95 \%$ confidence interval $7.7-26.8)$, gestational age $<32$ weeks ( $p<0.0005$, odds ratio $40.8,95 \%$ confidence interval 19.8-84.1), <10 customised birth weight centile, $(p<0.0005$, odds ratio 3.9, 95\% confidence interval 2.4-6.2), male gender $(p=0.007$, odds ratio $1.5,95 \%$ confidence interval $1.1-2.1)$, any reported prenatal infection $(p=0.008$, odds 


\section{Chapter 7 Multivariable Analysis}

ratio $1.9,95 \%$ confidence interval $1.2-3.0$ ), complications of the umbilical cord ( $p=0.01$, odds ratio $1.89,95 \%$ confidence interval $1.1-3.2$ ), relative with cerebral palsy ( $p=0.01$, odds ratio $1.8,95 \%$ confidence interval 1.1-2.9), maternal carriage of TGF- $\beta 1-509(p=0.04$, odds ratio $1.3,95 \%$ confidence interval 1.0-1.6). All other factors were no longer significant. Factors of interest in the subgroup analysis included having a relative with cerebral palsy (quadriplegia, $p=0.002$, odds ratio, $2.38,95 \%$ confidence interval $1.40-4.06$ ). When considering ante partum risk factors, the interaction of maternal TNF- $\alpha 308$ with infection was also significantly associated with cerebral palsy ( $p=0.02$, odds ratio $0.7,95 \%$ confidence interval $0.47-0.93$ ).

\section{Discussion}

This analysis is one of the few to combine epidemiological and genetic risk factors, along with their interaction, in a model of cerebral palsy. The case-control prediction in this cohort was $83.4 \%$, slightly higher than that published in the literature. The inclusion of genetic risk factors did not improve the prediction. Analysis of cerebral palsy subtypes identified a relative with cerebral palsy as a particularly strong risk for quadriplegia, and ante partum risk factors highlighted the importance of the maternal genome.

\section{Conclusions}

Cerebral palsy is significantly associated with prenatal infection, umbilical cord complications, delivery $<32$ weeks, Apgar score (one minute) $<4,<10^{\text {th }}$ customised birth weight centile, maternal genotype for TGF- $\beta 1-509$, male gender and a family history of cerebral palsy. Significant risk factors of maternal genotype, male gender and family history are consistent with a genetic contribution in some cases of cerebral palsy, especially quadriplegia. The significant interaction of maternal TNF- $\alpha 308$ with infection, particularly in the ante partum risks, supports the hypothesis that genetic susceptibility may be expressed in the presence of infection. 


\section{Chapter $7 \quad$ Multivariable Analysis}

\section{Introduction}

This chapter describes the assessment of risk factors for cerebral palsy identified in chapters 4, 5 and 6 in a multivariable analysis using logistic regression. A number of multivariable analyses for cerebral palsy have been published to date ${ }^{4} 1291451461478743$ and these have included both epidemiological and genetic risk factors. Analyses by Nelson et al. demonstrated that cerebral palsy is usually of ante-partum origin and could correctly identify $36.7 \%$ of 189 cases, albeit with $97 \%$ false positives. Polivka et al. examined 112 cases and 153 controls and was able to correctly classify $82 \%$ of cases and controls, but did not report the specificity and sensitivity of their model. This chapter extends the literature in a number of ways. Firstly, the analyses consider interactions between genetic variables and also between genetic and epidemiological variables. Interactions are assessed in a pair-wise fashion using biological hypotheses to guide selection of conceivably important combinations. Although it is possible to test all combinations in a pair-wise fashion, this strategy would generate a large number of tests (considering the limited numbers in some exposure categories), each with little power and increased chance of type I and II error. Secondly, this analysis is the first to perform logistic regression comparing specific risk factors between cerebral palsy subtypes. This is an important extension as the previous analyses have considered all subtypes together or composite risks ${ }^{148}$. Given the postulation of Stanley et al. ${ }^{109}$ that cerebral palsy is a group of conditions, it is reasonable to hypothesise that different subtypes may have different causal pathways. This analysis considers cerebral palsy subtypes as separate end points allowing comparison between them and assessment of the relative contributions of each risk factor to each subtype. Finally, an analysis is performed using only ante partum risk factors for cerebral palsy, in order to address the question of whether some of the postnatal 'predictors' of cerebral palsy may actually be 'markers' of the condition. 


\section{Chapter 7 Multivariable Analysis}

\section{Methods}

Logistic regression was performed using PASW Statistics 17.0.2 (SPSS Inc. Chicago, III). Selection of cases and controls is described in chapter 3 there being a final total of 587 cases and 1,154 controls. Only those individuals with data on all variables were included in each analysis and the numbers are reported. Variables were selected from the univariable analysis conducted in chapters $4-6$, with those significant at the level of $p<0.1$ selected for inclusion. Initially, all variables were modelled simultaneously. The dependent variable was cerebral palsy or specific subtypes hemiplegia, diplegia, quadriplegia and other cerebral palsy types. All models included a constant term. Results are reported as an odds ratio with $95 \%$ confidence interval. The null hypothesis was rejected at $p<0.05$ and the overall rate of successful case-control classification prediction, sensitivity (correct case prediction) and specificity (correct control prediction) were calculated for each model. Model fit was assessed by a Hosmer-Lemeshow test. Variables selected for inclusion in the model are listed in Tables 1 (epidemiological variables), 2 (child's genetics) and 3 (mother's genetics). Interactions were assessed by logistic regression for the same variables. While it is theoretically possible to test pair-wise interactions between all SNPs in the child's panel, all SNPs in the mother's panel, all epidemiological factors and then combinations thereof; this would create a large number of tests, most of which would be of little interest. Here, a hypothesis driven approach is used considering simultaneous carriage of a SNP by mother and child where the SNP was significant at the level of $p<0.1$ in the univariable analysis. Interaction variables for SNPs were constructed by multiplying the coding for each SNP pair under consideration. SNPs were coded as the number of alleles present per individual i.e. 0 , 1 or 2 and multiplication of mother and child therefore led to a set of values $\{0,1,2$, or 4$\}$. This predictor was then treated as a 'trend' variable in the regression analysis (an investigation using conventional category variables would have resulted in too few counts in key combinations of alleles). Infection was considered the most likely epidemiological variable to interact with the candidate SNPs in this panel. SNPs significant at the level of $p<0.1$ in the univariable analysis were 


\section{Chapter $7 \quad$ Multivariable Analysis}

assessed for multiplicative interaction with infection. Interactions were considered significant at $p<0.05$. A final model included all factors considered significant in the multivariable analyses of child's SNPs, mother's SNPs, mother-child SNP interactions, SNP-infection interactions and epidemiological risk factors. A flow diagram shown in figure 1 summarises the analyses conducted.

Variables which could only be observed postpartum were removed for an alternative multivariable analysis as it is uncertain whether they are genuine predictors/antecedents of cerebral palsy or part of the cerebral palsy phenotype. Apgar score less than four at one minute was removed from this analysis as it could be a consequence of the phenotype. Gestational age less than 32 weeks was removed as it could also be considered a part of the cerebral palsy phenotype and not necessarily a risk factor per se. Although birth weight is obtained post partum, we included customised birth weight less than the $10^{\text {th }}$ centile in our analysis as we considered this to be a proxy marker of intrauterine growth restriction, an ante partum event that may contribute to cerebral palsy causation. 


\section{Figure 1}

Flow diagram of multivariable analysis

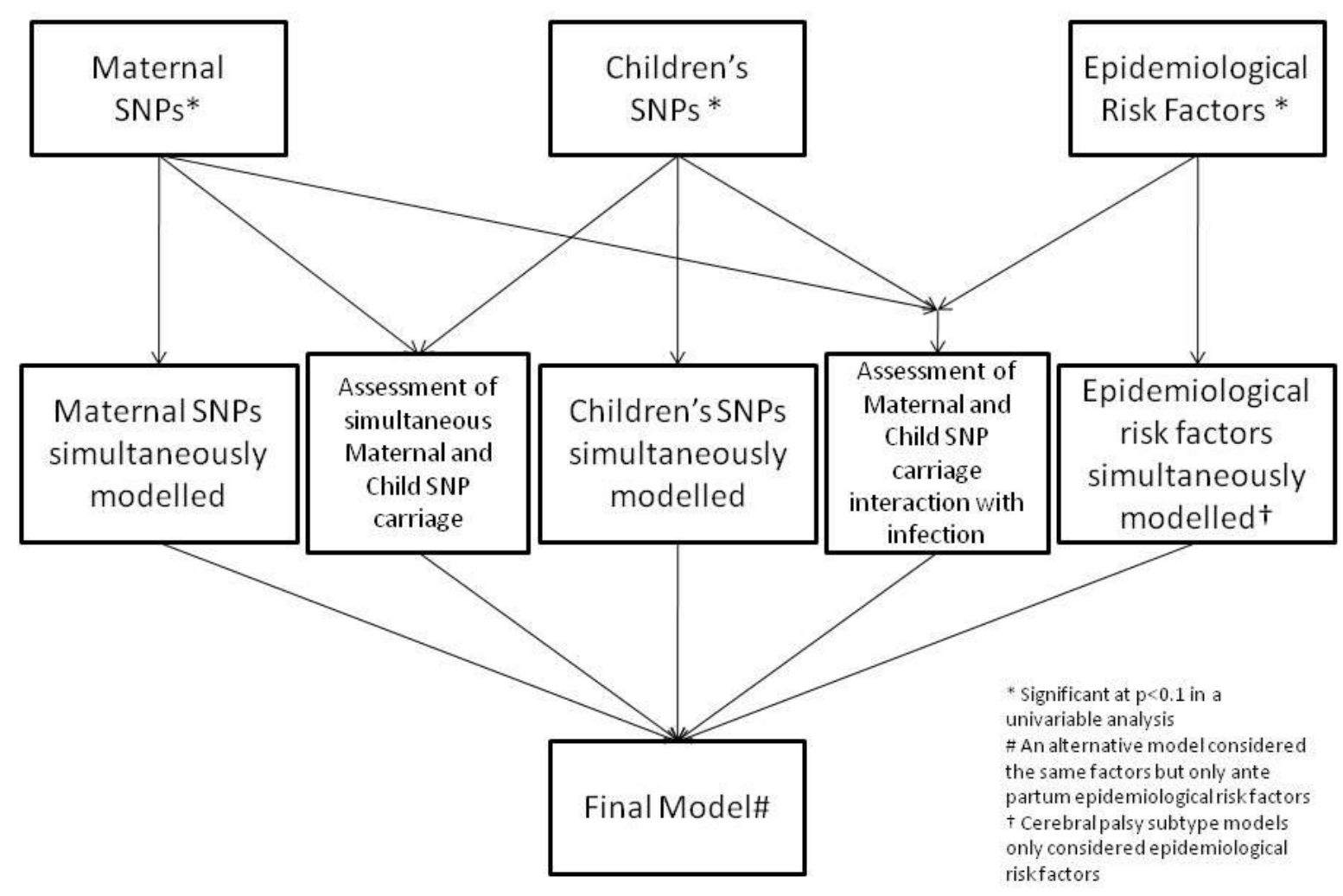




\section{Chapter $7 \quad$ Multivariable Analysis}

\section{Table 1}

Epidemiological risk factors for cerebral palsy with $p$ values $<0.1$ in the univariable analysis

\begin{tabular}{|c|c|c|}
\hline Risk Factor & $P$ value in univariable analysis & Odds ratio ( $95 \%$ confidence interval) \\
\hline Maternal infection reported & $<0.0005$ & $1.71(1.39-2.11)$ \\
\hline Small for gestational age ( $<10$ th centile) & $<0.0005$ & $4.35(2.92-6.48)$ \\
\hline Gestational age ( $<32$ weeks) & $<0.0005$ & $59.2(28.9-121)$ \\
\hline Multiple birth & $<0.0005$ & $6.62(4.00-10.9)$ \\
\hline Breech presentation & $<0.0005$ & $2.48(1.76-3.49)$ \\
\hline latrogenic heat in labour & $<0.0005$ & $0.47(0.36-0.61)$ \\
\hline Bleeding in pregnancy & $<0.0005$ & $2.04(1.61-2.58)$ \\
\hline Apgar score ( 1 minute; $<4$ vs $>8) \neq$ & $<0.0005$ & $20.3(11.3-36.4)$ \\
\hline Male gender & $<0.0005$ & $1.68(1.38-2.06)$ \\
\hline Caesarean delivery* & $<0.0005$ & $1.91(1.54-2.35)$ \\
\hline Complications of the umbilical cordt & 0.001 & $1.86(1.28-2.71)$ \\
\hline Any relative with cerebral palsy & 0.010 & $1.61(1.12-2.32)$ \\
\hline Drug use & 0.016 & $2.22(1.14-4.30)$ \\
\hline Smoking & 0.037 & $1.37(1.02-1.85)$ \\
\hline Any miscarriages & 0.053 & $1.25(1.00-1.57)$ \\
\hline Diabetes & 0.083 & $1.50(0.95-2.39)$ \\
\hline
\end{tabular}

‡ for the multivariable analysis described in this chapter, Apgar score (one minute) $<4$ compared to scores $>4$ was used

* emergency and elective caesarean reported separately in univariable analysis and combined here

tincludes a composite of nuchal cord, cord entanglement and cord prolapse 


\section{Chapter 7 Multivariable Analysis}

\section{Table 2}

Child's genetic risk factors for cerebral palsy with $p$ values $<0.1$ in the univariable analysis

\begin{tabular}{|c|c|c|}
\hline Risk Factor & P value in univariable analysis & Odds ratio (95\% confidence interval) \\
\hline MMP-2 & 0.027 & $1.20(1.02-1.41)$ \\
\hline MBL codon 52 & 0.04 & $1.31(1.01-1.70)$ \\
\hline PAl-2 & 0.044 & $0.84(0.70-1.00)$ \\
\hline MBL-550 & 0.056 & $1.16(1.00-1.34)$ \\
\hline IL-10 819 & 0.09 & $0.86(0.73-1.2)$ \\
\hline TNF- $\alpha$ 308 & 0.09 & $0.85(0.71-1.02)$ \\
\hline PAl-2 & 0.095 & $0.86(0.72-1.03)$ \\
\hline
\end{tabular}

\section{Table 3}

Mother's genetic risk factors for cerebral palsy with $p$ values $<0.1$ in the univariable analysis

\begin{tabular}{|c|c|c|}
\hline Risk Factor & P value in univariable analysis & Odds ratio (95\% confidence interval) \\
\hline TGF-B1-509 & 0.005 & $1.25(1.07-1.46)$ \\
\hline MBL+4 (P/Q) & 0.022 & $0.82(0.68-0.97)$ \\
\hline FVL & 0.05 & $1.51(1.00-2.28)$ \\
\hline MBL codon 52 (A/D) & 0.05 & $1.31(1.00-1.71)$ \\
\hline MBL-550 (H/L) & 0.05 & $1.16(1.00-1.34)$ \\
\hline IL-10-819 & 0.06 & $0.85(0.71-1.01)$ \\
\hline PAI-2 & 0.09 & $0.86(0.72-1.02)$ \\
\hline TNF- $\alpha$ 308 & 0.1 & $0.86(0.72-1.03)$ \\
\hline
\end{tabular}




\section{Chapter $7 \quad$ Multivariable Analysis}

\section{Results}

\section{Epidemiological data}

When considering all epidemiological data listed in Table 1 in a logistic regression, $<10^{\text {th }}$ customised birth weight centile, gestational age $<32$ weeks, Apgar score (one minute) $<4$, any relative with cerebral palsy, infection, male gender and complications of the umbilical cord remained significantly associated with cerebral palsy outcome (all $p<0.05$, Table 4). Factors which were no longer significant included use of heat during labour, bleeding during pregnancy, caesarean delivery, previous miscarriage, illicit drug use, breech position, smoking, diabetes and twins. This model included 844 controls and 296 cases. The sensitivity of prediction was $45.6 \%$ with $96.8 \%$ specificity and the overall prediction was $83.5 \%$. 


\section{Chapter $7 \quad$ Multivariable Analysis}

\section{Table 4}

Multivariable logistic regression of epidemiological risk factors for cerebral palsy (844 controls, 296 cases). Predictors were chosen if they were associated $(p<0.1)$ with cerebral palsy in the univariable analysis.

\begin{tabular}{|c|c|c|c|c|}
\hline & & & \multicolumn{2}{|c|}{ Odds ratio $95 \% \mathrm{Cl}$} \\
\hline Risk & P value & Odds ratio & Lower & Upper \\
\hline$<10$ th customised birth weight centile & $<0.0005$ & 3.39 & 2.05 & 5.62 \\
\hline Gestational age $<32$ weeks & $<0.0005$ & 58.8 & 21.3 & 166 \\
\hline Apgar score (one minute) <4 & $<0.0005$ & 14.92 & 7.5 & 29.4 \\
\hline Relative with cerebral palsy & $<0.009$ & 2 & 1.19 & 3.36 \\
\hline Any infection & 0.001 & 1.72 & 1.23 & 2.41 \\
\hline Male gender & 0.006 & 1.6 & 1.15 & 2.23 \\
\hline Complications of umbilical cord & 0.01 & 2.22 & 1.26 & 3.92 \\
\hline Use of heat during labour & 0.09 & 0.7 & 1.05 & 1.35 \\
\hline Bleeding during pregnancy & 0.15 & 1.34 & 0.89 & 2.04 \\
\hline Caesarean delivery & 0.24 & 1.26 & 0.86 & 1.85 \\
\hline Previous miscarriage & 0.45 & 0.86 & 0.59 & 1.26 \\
\hline Illicit drug use & 0.46 & 1.57 & 0.47 & 5.26 \\
\hline Breech & 0.53 & 1.24 & 0.62 & 2.49 \\
\hline Smoking & 0.87 & 1.04 & 0.63 & 1.78 \\
\hline Diabetes & 0.93 & 1.03 & 0.47 & 2.26 \\
\hline Twin & 0.97 & 0.98 & 0.42 & 2.31 \\
\hline
\end{tabular}




\section{Chapter $7 \quad$ Multivariable Analysis}

\section{Genetic data}

\section{Child's genetics}

A multivariable analysis of all child's SNPs significant in the univariable analysis showed a significant association of IL-10-819 ( $r s 1800871, p<0.05$, Table 5) with cerebral palsy. This model included 1,072 controls and 541 cases. The sensitivity of prediction was $0 \%$ with $100 \%$ specificity and the overall prediction in this cohort was $66.5 \%$, a result equivalent to the default prediction that all those in the cohort are controls.

\section{Table 5}

Multivariable logistic regression of child's genetic risk factors for cerebral palsy (1,072 controls, 541 cases). Predictors were chosen if they were associated $(p<0.1)$ with cerebral palsy in the univariable analysis.

\begin{tabular}{|c|c|c|c|c|}
\hline \multirow[t]{2}{*}{ Risk } & \multirow[b]{2}{*}{$P$ value } & \multirow[b]{2}{*}{ Odds ratio (per allele) } & \multicolumn{2}{|c|}{ Odds ratio $95 \% \mathrm{Cl}$} \\
\hline & & & Lower & Upper \\
\hline IL-10-819 & 0.03 & 0.81 & 0.68 & 0.98 \\
\hline TNF- $\alpha 308$ & 0.14 & 0.87 & 0.72 & 1.05 \\
\hline MBL codon 52 & 0.16 & 1.25 & 0.92 & 1.69 \\
\hline MMP-2 & 0.27 & 1.1 & 0.93 & 1.3 \\
\hline MBL-550 & 0.42 & 1.07 & 0.91 & 1.25 \\
\hline PAI-2_1 & 1 & - & - & . \\
\hline PAI-2_2 & 1 & 1 & 0 & . \\
\hline
\end{tabular}




\section{Chapter $7 \quad$ Multivariable Analysis}

\section{Mother's genetics}

A multivariable analysis of all mother's SNPs significant in the univariable analysis showed a significant association of FVL ( $r$ 6025) and TGF- $\beta 1-509$ ( $r s 1800469)$ with cerebral palsy (both $p<0.05$, Table 6). All other SNPs were no longer significantly associated with cerebral palsy. This model included 1,060 controls and 533 cases. The sensitivity of prediction was $1.3 \%$ with $99.6 \%$ specificity and the overall prediction in this cohort was $66.5 \%$.

\section{Table 6}

Multivariable logistic regression of mother's genetic risk factors for cerebral palsy (1,060 controls, 533 cases). Predictors were chosen if they were associated $(p<0.1)$ with cerebral palsy in the univariable analysis.

\begin{tabular}{|c|c|c|c|c|}
\hline \multirow{2}{*}{ Risk } & & & \multicolumn{2}{|c|}{ Odds ratio 95\% CI } \\
\hline TGF-11-509 & P value & Odds ratio (per allele) & Lower & Upper \\
\hline FVL & 0.02 & 1.21 & 1.03 & 1.42 \\
\hline PAl-2_2 & 0.05 & 1.53 & 0.99 & 2.37 \\
\hline IL-10-819 & 0.1 & 0.86 & 0.71 & 1.03 \\
\hline TNF- $\mathbf{\alpha} 308$ & 0.13 & 0.87 & 0.72 & 1.04 \\
\hline MBL codon 52 & 0.18 & 0.88 & 0.73 & 1.06 \\
\hline MBL+4 & 0.26 & 1.19 & 0.88 & 1.63 \\
\hline MBL-550 & 0.32 & 0.9 & 0.74 & 1.1 \\
\hline
\end{tabular}




\section{Chapter $7 \quad$ Multivariable Analysis}

\section{Interactions}

Simultaneous SNP carriage in mother and child

Mother or child SNPs associated $(p<0.1)$ with cerebral palsy in the univariable analysis were selected for interaction analysis. No maternal-child SNP interaction was significantly associated with cerebral palsy (Table 7) at $\mathrm{p}<0.05$ - but there are suggestions that a larger study with more power might see differences between certain mother-child pairings of alleles.

\section{Table 7}

Interaction of mother-child genetic risk factors for cerebral palsy. Predictors were chosen if they were associated $(p<0.1)$ with cerebral palsy in the univariable analysis.

\begin{tabular}{|c|c|c|c|}
\hline Risk factor & $\begin{array}{l}P \text { value in logistic } \\
\text { interaction }\end{array}$ & $\begin{array}{l}\text { Odds ratio ( } 95 \% \text { confidence } \\
\text { interval) per allele }\end{array}$ & Number of cases/controls \\
\hline Mother IL-10-819 by Child IL-10-819 & 0.06 & $0.86(0.74-1.00)$ & $583 / 1144$ \\
\hline Mother MBL codon 52 by Child MBL codon 52 & 0.07 & $1.35(0.98-1.86)$ & $586 / 1148$ \\
\hline Mother PAI-2_2 by Child PAI-2_2 & 0.07 & $0.87(0.75-1.01)$ & $578 / 1145$ \\
\hline Mother MBL-550 by Child MBL- 550 & 0.1 & $1.08(0.99-1.19)$ & $567 / 1133$ \\
\hline Mother PAI-2_1 by Child PAI-2_1 & 0.1 & $0.88(0.75-1.02)$ & $568 / 1102$ \\
\hline Mother TGF- $\beta 1-509$ by Child TGF- $\beta 1-509$ & 0.17 & $1.08(0.97-1.21)$ & $575 / 1125$ \\
\hline Mother MBL +4 by Child MBL+4 & 0.18 & $0.90(0.78-1.05)$ & $579 / 1133$ \\
\hline Mother TNF- $\alpha 308$ by Child TNF- $\alpha 308$ & 0.19 & $0.90(0.76-0.90)$ & $581 / 1143$ \\
\hline Mother FVL by Child FVL & 0.36 & $1.27(0.76-2.11)$ & $568 / 1152$ \\
\hline Mother MMP-2 by Child MMP-2 & 0.43 & $1.05(0.93-1.19)$ & $581 / 1150$ \\
\hline
\end{tabular}




\section{Chapter 7 Multivariable Analysis}

Interaction of genetic risk factors with infection

Interaction of all SNPs significant in the univariable analysis with infection showed that maternal MBL+4, TNF- $\alpha$ 308, IL-10-819, PAI-2_2 are associated differently with cerebral palsy in the presence and absence of infection, and similarly the association of child carriage of PAI-2_1, PAI-2_2, IL-10-819 and TNF- $\alpha 308$ with cerebral palsy varies depending on the presence or absence of an antenatal infection (all $p<0.05$, Table 8). All other interactions were not significant. 


\section{Chapter $7 \quad$ Multivariable Analysis}

\section{Table 8}

Interaction of mother and child genetic risk factors with infection and their association with cerebral palsy. Predictors were chosen if they were associated $(p<0.1)$ with cerebral palsy in the univariable analysis.

\begin{tabular}{|c|c|c|c|}
\hline Mother's risk factor & $P$ value in logistic interaction & $\begin{array}{l}\text { Odds ratio ( } 95 \% \text { confidence } \\
\text { interval) per allele }\end{array}$ & Number of cases/controls \\
\hline Mother MBL+4 by infection & $<0.0005$ & $1.47(1.19-1.81)$ & $579 / 1133$ \\
\hline Mother TNF- $\alpha 308$ by infection & $<0.0005$ & $1.51(1.23-1.86)$ & $581 / 1143$ \\
\hline Mother IL-10-819 by infection & 0.009 & $1.31(1.07-1.61)$ & $583 / 1144$ \\
\hline Mother PAI-2_2 by infection & 0.023 & $1.27(1.03-1.56)$ & $578 / 1145$ \\
\hline Mother MBL codon 52 by infection & 0.14 & $0.79(0.57-1.08)$ & $586 / 1148$ \\
\hline Mother FVL by infection & 0.41 & $0.59(0.36-0.98)$ & $586 / 1152$ \\
\hline Mother MBL-550 by infection & 0.65 & $1.04(0.89-1.21)$ & $567 / 1133$ \\
\hline Mother TGF- $\beta 1-509$ by infection & 0.77 & $0.97(0.82-1.16)$ & $575 / 1125$ \\
\hline Child's risk factor & $P$ value in logistic interaction & $\begin{array}{c}\text { Odds ratio ( } 95 \% \text { confidence } \\
\text { interval) }\end{array}$ & Number of cases/controls \\
\hline Child PAI-2_1 by infection & 0.001 & $1.44(1.17-1.78)$ & $587 / 1154$ \\
\hline Child PAI-2_ 2 by infection & 0.001 & $1.41(1.15-1.74)$ & $587 / 1154$ \\
\hline Child IL-10-819 by infection & 0.002 & $1.37(1.12-1.67)$ & $587 / 1154$ \\
\hline Child TNF- $\alpha 308$ by infection & 0.01 & $1.32(1.06-1.64)$ & $587 / 1154$ \\
\hline Child MBL codon 52 by infection & 0.31 & $0.85(0.62-1.17)$ & $587 / 1154$ \\
\hline Child MMP-2 by infection & 0.59 & $1.05(0.87-1.27)$ & $587 / 1154$ \\
\hline Child MBL-550 by infection & 0.91 & $0.99(0.85-1.15)$ & $587 / 1154$ \\
\hline
\end{tabular}




\section{Chapter 7 Multivariable Analysis}

\section{Combined epidemiological and genetic data}

Variables significant $(p<0.05)$ in the epidemiological, genetic and interaction multivariable analyses were combined and a further model generated (Table 9). Variables no longer considered significant were child's carriage of IL-10-819 and Factor V Leiden (FVL) SNPs and all SNP interactions with infection. All other factors remained significant. This model included 972 controls and 340 cases. This model was able to predict the case control status of $83.4 \%$ of the cohort correctly with sensitivity of $45.0 \%$ and specificity of $96.8 \%$. A HosmerLemeshow test indicated that the model was an excellent fit of the data with a Chi squared value of 8.92 (eight degrees of freedom, p0.035). 


\section{Table 9}

Multivariable logistic regression of epidemiological risks, genetic risks and genetic risk interactions with infection for cerebral palsy. Predictors were chosen if they were associated $(p<0.05)$ with cerebral palsy in the initial multivariable analysis. (972 controls, 340 cases)

\begin{tabular}{|c|c|c|c|c|}
\hline \multirow[t]{2}{*}{ Risk } & \multirow[b]{2}{*}{$P$ value } & \multirow[b]{2}{*}{ Odds ratio } & \multicolumn{2}{|c|}{ Odds ratio $95 \% \mathrm{Cl}$} \\
\hline & & & Lower & Upper \\
\hline Apgar score (one minute) $<4$ & $<0.0005$ & 14.3 & 7.67 & 26.8 \\
\hline Gestational age $<32$ weeks & $<0.0005$ & 40.8 & 19.8 & 84.1 \\
\hline $\begin{array}{c}<10^{\text {th }} \text { customised birth weight } \\
\text { centile }\end{array}$ & $<0.0005$ & 3.86 & 2.4 & 6.21 \\
\hline Male gender & 0.007 & 1.52 & 1.12 & 2.06 \\
\hline Any Infection & 0.008 & 1.89 & 1.18 & 3.03 \\
\hline Complications of umbilical cord & 0.01 & 1.89 & 1.11 & 3.2 \\
\hline Relative with cerebral palsy & 0.01 & 1.82 & 1.13 & 2.93 \\
\hline Mother TGF- $\beta 1-509$ & 0.04 & 1.27 & 1.01 & 1.6 \\
\hline Mothers FVL & 0.12 & 1.57 & 0.89 & 2.78 \\
\hline Infection by Mother TNF- $\alpha 308$ & 0.18 & 0.74 & 0.48 & 1.15 \\
\hline Infection by Mother PAI-2_2 & 0.22 & 0.38 & 0.08 & 1.78 \\
\hline Child IL-10-819 & 0.35 & 0.85 & 0.6 & 1.2 \\
\hline Infection by Mother IL-10-819 & 0.42 & 1.26 & 0.72 & 2.22 \\
\hline Infection by Mother MBL+4 & 0.5 & 0.87 & 0.59 & 1.3 \\
\hline Infection by Child PAI-2_1 & 0.52 & 1.66 & 0.36 & 7.61 \\
\hline
\end{tabular}




\section{Chapter 7 Multivariable Analysis}

\section{Alternative models}

The above analysis considered all risk factors identified as associated with cerebral palsy in the univariable analysis $(p<0.1)$. Alternative analyses were performed considering 1$)$ cerebral palsy subtypes, 2) gestational age subgroups and 3) only ante-partum risk factors for cerebral palsy.

Comparing cerebral palsy subtypes

The multivariable model of all epidemiological variables significant at the level of $p<0.1$ in the univariable analysis was applied to the subgroups of cerebral palsy: hemiplegia, diplegia, quadriplegia and other cerebral palsy types (Table 10). For the hemiplegia model, only infection, complications of the umbilical cord, Apgar score (one minute) $<4$, gestational age $<32$ weeks and $<10^{\text {th }}$ customised birth weight centile remained significant. For diplegia, infection, bleeding during pregnancy, Apgar score (one minute) $<4$, male gender, gestational age $<32$ weeks and $<10^{\text {th }}$ customised birth weight centile remained significant. For quadriplegia, only a relative with cerebral palsy, Apgar score (one minute) $<4$, gestational age $<32$ weeks and $<10^{\text {th }}$ customised birth weight centile remained significant. For all other cerebral palsy types, only Apgar score (one minute) $<4$ and gestational age $<32$ weeks remained significant.

The same variables were also used to assess cerebral palsy cases born at $<32$ weeks gestational age and $>36$ weeks gestational age (Table 11 ). For the $<32$ weeks group, significant factors included infection, twins, breech position, heat use during labour, illicit drug use, bleeding during pregnancy, Apgar score (one minute) $<4$, male gender and $<10^{\text {th }}$ customised birth weight centile. For those born at $>36$ weeks, significant factors included infection, complications of the umbilical cord, a relative with cerebral palsy, Apgar score (one minute) $<4$, male gender and $<10^{\text {th }}$ customised birth weight centiles for gestational age. 
The number of cases and controls used in each model together with the specificity, sensitivity and overall predictive success of each model (using all variables simultaneously) in this cohort is given in Table 12 with an overall summary in Table 13.

\section{Table 10}

Multivariable logistic regression of cerebral palsy subtypes. Predictors were chosen if they were associated $(p<0.05)$ with cerebral palsy in the initial multivariable analysis.

\begin{tabular}{|c|c|c|c|c|c|c|c|c|}
\hline \multirow[t]{2}{*}{ Risk } & \multicolumn{2}{|c|}{ Hemiplegia } & \multicolumn{2}{|c|}{ Diplegia } & \multicolumn{2}{|c|}{ Quadriplegia } & \multicolumn{2}{|c|}{ Other cerebral palsy types } \\
\hline & $P$ value & $\begin{array}{l}\text { Odds ratio } \\
(95 \% \mathrm{Cl})\end{array}$ & $P$ value & $\begin{array}{c}\text { Odds ratio (95\% } \\
\text { Cl) }\end{array}$ & $P$ value & $\begin{array}{c}\text { Odds ratio (95\% } \\
\text { CI) }\end{array}$ & $P$ value & $\begin{array}{l}\text { Odds ratio } \\
(95 \% \mathrm{Cl})\end{array}$ \\
\hline Any Infection & 0.02 & $\begin{array}{c}1.70(1.10- \\
2.64)\end{array}$ & 0.04 & $2.06(1.05-4.06)$ & 0.90 & $1.05(0.47-2.34)$ & 0.11 & $2.00(0.87-4.62)$ \\
\hline Twins & 0.77 & $\begin{array}{c}0.82(0.22- \\
3.10)\end{array}$ & 0.30 & $0.41(0.08-2.20)$ & 0.57 & $1.65(0.30-9.22)$ & 0.45 & $0.40(0.04-4.41)$ \\
\hline Breech & 0.74 & $\begin{array}{c}1.18(0.45- \\
3.05)\end{array}$ & 0.06 & $3.09(0.98-9.79)$ & 0.43 & $0.54(0.16-2.52)$ & 0.13 & $0.14(0.01-1.83)$ \\
\hline Heat during labour & 0.15 & $\begin{array}{c}0.67(0.39- \\
1.15)\end{array}$ & 0.39 & $0.68(0.29-1.62)$ & 0.25 & $0.56(0.21-1.50)$ & 0.36 & $0.62(0.22-1.72)$ \\
\hline Illicit drug use & 0.87 & $\begin{array}{l}0.83(0.10- \\
6.92)\end{array}$ & 0.71 & $\begin{array}{c}1.59(0.14- \\
17.69)\end{array}$ & 0.20 & $\begin{array}{c}1.02(0.48- \\
33.82)\end{array}$ & 1.00 & - \\
\hline Smoking & 0.27 & $\begin{array}{c}0.64(0.29- \\
1.42)\end{array}$ & 0.15 & $1.91(0.79-4.65)$ & 0.67 & $1.28(0.42-3.84)$ & 0.16 & $0.22(0.03-1.85)$ \\
\hline Medical anaemia & 0.58 & $\begin{array}{c}0.78(0.32- \\
1.90)\end{array}$ & 0.32 & $0.40(0.06-2.48)$ & 0.71 & $0.74(0.16-3.54)$ & 0.90 & $0.90(0.19-4.24)$ \\
\hline Complications of umbilical cord & 0.01 & $\begin{array}{c}2.50(1.25- \\
5.01)\end{array}$ & 0.08 & $2.46(0.90-6.70)$ & 0.51 & $1.48(0.45-4.84)$ & 0.70 & $1.35(0.29-6.43)$ \\
\hline Bleeding during pregnancy & 0.87 & $\begin{array}{c}0.95(0.53- \\
1.70)\end{array}$ & 0.01 & $2.68(1.29-5.57)$ & 0.53 & $0.71(0.25-2.05)$ & 0.31 & $1.63(0.64-4.15)$ \\
\hline Relative with cerebral palsy & 0.10 & $\begin{array}{c}1.80(0.89- \\
3.64)\end{array}$ & 0.20 & $1.99(0.70-5.67)$ & 0.03 & $3.27(1.13-9.45)$ & 0.56 & $1.53(0.38-6.20)$ \\
\hline Apgar score (one minute) $<4$ & $<0.0005$ & $\begin{array}{c}5.89(2.26- \\
15.35)\end{array}$ & 0.002 & $\begin{array}{c}8.06(2.21- \\
29.42)\end{array}$ & $<0.0005$ & $\begin{array}{c}95.06(35.29- \\
256.07)\end{array}$ & $<0.0005$ & $\begin{array}{c}20.34(5.83- \\
71.04)\end{array}$ \\
\hline Diabetes & 0.44 & $\begin{array}{c}1.44(0.58- \\
3.60)\end{array}$ & 0.48 & $0.55(0.10-2.91)$ & 0.17 & $0.25(0.03-1.84)$ & 0.31 & $0.23(0.01-4.01)$ \\
\hline Male gender & 0.18 & $\begin{array}{c}1.34(0.87- \\
2.08)\end{array}$ & 0.01 & $2.46(1.21-4.94)$ & 0.09 & $1.97(0.90-4.30)$ & 0.30 & $1.54(0.68-3.50)$ \\
\hline Caesarean delivery & 0.46 & $\begin{array}{c}1.21(0.73- \\
2.01)\end{array}$ & 0.55 & $1.27(0.58-2.76)$ & 0.11 & $1.94(0.87-4.33)$ & 0.23 & $1.70(0.72-4.01)$ \\
\hline Previous miscarriage & 0.08 & $\begin{array}{c}0.62(0.37- \\
1.06)\end{array}$ & 0.76 & $0.89(0.43-1.86)$ & 0.50 & $0.74(0.30-1.81)$ & 0.42 & $1.42(0.60-3.33)$ \\
\hline Gestational age $<32$ weeks & $<0.0005$ & $\begin{array}{c}27.66(8.38- \\
91.31)\end{array}$ & $<0.0005$ & $\begin{array}{c}185.63(45.65- \\
754.96)\end{array}$ & $<0.0005$ & $\begin{array}{c}234.07(56.41- \\
971.31)\end{array}$ & $<0.0005$ & $\begin{array}{c}92.66(12.31- \\
697.77)\end{array}$ \\
\hline$<10^{\text {th }}$ customised birth weight centile & 0.01 & $\begin{array}{c}2.48(1.24- \\
4.97)\end{array}$ & 0.001 & $4.08(1.72-9.70)$ & 0.003 & $\begin{array}{c}4.82(1.73- \\
13.51)\end{array}$ & 0.02 & $\begin{array}{c}3.97(1.24- \\
12.70)\end{array}$ \\
\hline
\end{tabular}




\section{Chapter $7 \quad$ Multivariable Analysis}

\section{Table 11}

Multivariable logistic regression of cerebral palsy gestational age subgroups. Predictors were chosen if they were associated $(p<0.05)$ with cerebral palsy in the initial multivariable analysis.

\begin{tabular}{|c|c|c|c|c|c|c|c|c|}
\hline \multirow[t]{3}{*}{ Risk } & \multicolumn{4}{|c|}{$<32$ weeks gestational age } & \multicolumn{4}{|c|}{$>36$ weeks gestational age } \\
\hline & \multirow[b]{2}{*}{$P$ value } & \multirow[b]{2}{*}{ Odds ratio } & \multicolumn{2}{|c|}{ Odds ratio $95 \% \mathrm{Cl}$} & \multirow[b]{2}{*}{$P$ value } & \multirow[b]{2}{*}{$\begin{array}{l}\text { Odds } \\
\text { ratio }\end{array}$} & \multicolumn{2}{|c|}{ Odds ratio $95 \% \mathrm{Cl}$} \\
\hline & & & Lower & Upper & & & Lower & Upper \\
\hline Any infection & 0.05 & 1.77 & 0.99 & 3.15 & 0.01 & 1.64 & 1.14 & 2.37 \\
\hline Twins & $<0.0005$ & 15.64 & 6.67 & 36.69 & 0.36 & 0.48 & 0.10 & 2.27 \\
\hline Breech & 0.001 & 3.75 & 1.78 & 7.90 & 0.36 & 1.46 & 0.65 & 3.27 \\
\hline Heat during labour & 0.001 & 0.09 & 0.02 & 0.40 & 0.17 & 0.74 & 0.48 & 1.14 \\
\hline Illicit drug use & 0.02 & 7.11 & 1.38 & 36.66 & 0.51 & 1.57 & 0.41 & 5.92 \\
\hline Smoking & 0.81 & 1.11 & 0.47 & 2.61 & 0.93 & 0.97 & 0.54 & 1.76 \\
\hline Medical anaemia & 0.17 & 0.37 & 0.09 & 1.51 & 0.54 & 0.80 & 0.39 & 1.62 \\
\hline Complications of umbilical cord & 0.66 & 0.71 & 0.16 & 3.25 & 0.04 & 2.35 & 1.31 & 4.22 \\
\hline Bleeding during pregnancy & $<0.0005$ & 5.50 & 3.03 & 10.00 & 0.28 & 1.28 & 0.82 & 2.02 \\
\hline Relative with cerebral palsy & 0.80 & 1.15 & 0.38 & 3.46 & 0.001 & 2.38 & 1.40 & 4.06 \\
\hline Apgar score (one minute) $<4$ & 0.003 & 6.37 & 1.87 & 21.70 & $<0.0005$ & 15.18 & 7.48 & 30.77 \\
\hline Diabetes & 0.51 & 0.64 & 0.16 & 2.45 & 0.85 & 1.09 & 0.46 & 2.54 \\
\hline Male gender & 0.008 & 2.21 & 1.23 & 3.96 & 0.02 & 1.56 & 1.09 & 2.24 \\
\hline Caesarean delivery & 0.23 & 1.47 & 0.78 & 2.75 & 0.86 & 1.04 & 0.68 & 1.60 \\
\hline Previous miscarriage & 0.65 & 0.87 & 0.47 & 1.60 & 0.95 & 0.99 & 0.66 & 1.48 \\
\hline$<10^{\text {th }}$ customised birth weight centile & $<0.0005$ & 4.52 & 2.08 & 9.86 & $<0.0005$ & 3.04 & 1.73 & 5.34 \\
\hline
\end{tabular}


Chapter 7 Multivariable Analysis

\section{Table 12}

Number of cases and controls together with sensitivity, specificity and overall predictive success of logistic regressions in Tables 8 and 9.

\begin{tabular}{|c|c|c|c|c|c|}
\hline Subgroup & Controls included & Cases included & Sensitivity (\%) & Specificity (\%) & Overall prediction in this cohort (\%) \\
\hline Hemiplegia & 844 & 114 & 20.2 & 99.4 & 90.0 \\
\hline Diplegia & 844 & 70 & 42.9 & 99.2 & 94.9 \\
\hline Quadriplegia & 844 & 67 & 65.7 & 98.3 & 95.9 \\
\hline Other cerebral palsy types & 844 & 33 & 21.2 & 99.6 & 96.7 \\
\hline <3 weeks gestational age & 844 & 84 & 35.7 & 98.2 & 92.6 \\
\hline
\end{tabular}




\section{Chapter $7 \quad$ Multivariable Analysis}

\section{Table 13}

Summary of statistically significant associations with subtypes of cerebral palsy from multivariable logistic regressions in Tables 10-11.

\begin{tabular}{|c|c|c|c|c|c|c|}
\hline & Hemiplegia & Diplegia & Quadriplegia & $\begin{array}{l}\text { Other cerebral } \\
\text { palsy types }\end{array}$ & $\begin{array}{c}<32 \text { weeks } \\
\text { gestational age }\end{array}$ & $\begin{array}{c}>36 \text { weeks } \\
\text { gestational age }\end{array}$ \\
\hline Apgar score (one minute) $<4$ & + & + & + & + & + & + \\
\hline Gestational age $<32$ weeks & + & + & + & + & N/A & N/A \\
\hline $\begin{array}{l}<10 \text { th customised birth } \\
\text { weight centile }\end{array}$ & + & + & + & + & + & + \\
\hline Any Infection & + & + & & & + & + \\
\hline Male gender & & + & & & + & + \\
\hline Relative with cerebral palsy & & & + & & & + \\
\hline Twins & & & & & + & \\
\hline Breech & & & & & + & \\
\hline Heat during labour & & & & & + & \\
\hline Illicit drug use & & & & & + & \\
\hline \multicolumn{7}{|l|}{ Smoking } \\
\hline \multicolumn{7}{|l|}{ Medical anaemia } \\
\hline $\begin{array}{l}\text { Complications of umbilical } \\
\text { cord }\end{array}$ & + & & & & & + \\
\hline Bleeding during pregnancy & & + & & & + & \\
\hline \multicolumn{7}{|l|}{ Diabetes } \\
\hline \multicolumn{7}{|l|}{ Caesarean delivery } \\
\hline Previous miscarriage & & & & & & \\
\hline
\end{tabular}


Risk factors of ante partum origin

\section{Epidemiological risk factors of ante partum origin}

A multivariable analysis of ante partum epidemiological risk factors is presented in Table 14. Inclusion of only ante partum factors removed the influence of measures taken post partum which could be either predictors of cerebral palsy or part of the phenotype. This model included 1,059 controls and 520 cases. The sensitivity of prediction was $29.2 \%$ with $93.3 \%$ specificity and the overall prediction in this cohort was $72.2 \%$.

\section{Table 14}

Multivariable analysis of the ante partum epidemiological risk factors for cerebral palsy $(1,059$ controls and 520 cases). Predictors were chosen if they were associated $(p<0.1)$ with cerebral palsy in the univariable analysis.

\begin{tabular}{|c|c|c|c|c|}
\hline & & & \multicolumn{2}{|c|}{ OR $95 \% \mathrm{Cl}$} \\
\hline Risk & $P$ value & OR & Lower & Upper \\
\hline Twin & $<0.005$ & 4.57 & 2.56 & 8.17 \\
\hline$<10$ th customised birth weight centile & $<0.005$ & 3.12 & 2.16 & 4.52 \\
\hline Complications of umbilical cord & $<0.005$ & 2.29 & 1.47 & 3.54 \\
\hline Relative with cerebral palsy & $<0.005$ & 1.82 & 1.22 & 2.72 \\
\hline Any infection & $<0.005$ & 1.58 & 1.23 & 2.02 \\
\hline Male gender & $<0.005$ & 1.90 & 1.49 & 2.42 \\
\hline Heat during labour & $<0.005$ & 0.58 & 0.43 & 0.78 \\
\hline Bleeding during pregnancy & $<0.005$ & 1.88 & 1.41 & 2.51 \\
\hline Breech & 0.01 & 1.86 & 1.19 & 2.92 \\
\hline Illicit drug use & 0.11 & 1.95 & 0.86 & 4.40 \\
\hline Caesarean delivery & 0.12 & 1.25 & 0.95 & 1.66 \\
\hline Smoking & 0.47 & 1.15 & 0.78 & 1.70 \\
\hline Diabetes & 0.53 & 1.20 & 0.68 & 2.11 \\
\hline Previous miscarriage & 0.67 & 1.06 & 0.81 & 1.38 \\
\hline
\end{tabular}




\section{Chapter $7 \quad$ Multivariable Analysis}

\section{Combined epidemiological and genetic risk factors of ante partum origin}

Ante partum epidemiological factors significant in the multivariable analysis (Table 14) were combined with genetic risk factors that were significant in multivariable analysis (Tables 58). This model is presented in Table 15. The model included 972 controls and 340 cases. The sensitivity of prediction was $42.9 \%$ with $97.2 \%$ specificity and the overall prediction in this cohort was $83.2 \%$. 


\section{Chapter $7 \quad$ Multivariable Analysis}

\section{Table 15}

Multivariable analysis of the ante partum epidemiological risk factors, genetic risk factors and genetic risk factor interactions with infection for cerebral palsy. Predictors were chosen if they were associated $(p<0.1)$ with cerebral palsy in the univariable analysis (genetic and genetic interaction factors) or the initial ante partum multivariable analysis (epidemiological factors).

\begin{tabular}{|c|c|c|c|c|}
\hline & & & \multicolumn{2}{|c|}{ OR $95 \% \mathrm{Cl}$} \\
\hline Risk & $P$ value & OR & Lower & Upper \\
\hline$<10$ th customised birth weight centile & $<0.0005$ & 3.45 & 2.39 & 4.97 \\
\hline Twin & $<0.0005$ & 4.61 & 2.66 & 8.00 \\
\hline Bleeding during pregnancy & $<0.0005$ & 2.05 & 1.57 & 2.69 \\
\hline Male gender & $<0.0005$ & 1.85 & 1.47 & 2.32 \\
\hline Any infection & $<0.0005$ & 2.13 & 1.49 & 3.06 \\
\hline Heat during labour & $<0.0005$ & 0.58 & 0.43 & 0.76 \\
\hline Breech & $<0.0005$ & 2.06 & 1.40 & 3.03 \\
\hline Relative with cerebral palsy & 0.001 & 1.95 & 1.34 & 2.86 \\
\hline Complications of umbilical cord & 0.003 & 1.86 & 1.24 & 2.81 \\
\hline Mother TNF- $\alpha 308$ by infection & 0.02 & 0.66 & 0.47 & 0.93 \\
\hline Mother TGF- $\beta 1-509$ & 0.04 & 1.20 & 1.01 & 1.42 \\
\hline Mother PAI-2_2 by infection & 0.15 & 0.40 & 0.11 & 1.38 \\
\hline Mothers FVL & 0.22 & 1.33 & 0.84 & 2.12 \\
\hline Infection by Child PAI-2_1 & 0.46 & 1.61 & 0.46 & 5.63 \\
\hline Child IL-10-819 & 0.48 & 0.91 & 0.71 & 1.17 \\
\hline Infection by Mother MBL+4 & 0.95 & 0.99 & 0.73 & 1.35 \\
\hline Infection by Mother IL-10-819 & 0.98 & 0.99 & 0.66 & 1.51 \\
\hline
\end{tabular}




\section{Chapter 7 Multivariable Analysis}

\section{Discussion}

\section{Epidemiological data}

This analysis confirmed many epidemiological risk factors for cerebral palsy that have been reported in previous studies. Gestational age $<32$ weeks, $<10^{\text {th }}$ customised birth weight centile and Apgar score (one minute) $<4$ remain the strongest predictors in this multivariable logistic regression model, while other factors significant in the univariable analysis were no longer significant after controlling for confounders. Interpretation of these associations requires caution as the model is unable to differentiate true causal risk factors of cerebral palsy and markers of the condition. An alternative analysis is presented with post partum measures removed. Low Apgar score, for example, suggests that an infant is in poor health in the first minutes of life. The infants' health may be poor because it has cerebral palsy already or it may an indicator of another causal event.

Having a relative with cerebral palsy remained a significant risk factor for cerebral palsy, which is an important observation since previous studies which made similar observations did not control for potential confounders such as gestational age and birth weight centile ${ }^{11}$. Maternal infection remained a moderate risk factor after controlling for gestational age and birth weight centile as did male gender possibly supporting an X linked aetiology. This model achieved prediction of $83.5 \%$ in this cohort, a marginal improvement on the model by Polivka et al. (82\%) 146.

\section{Genetic data}

Only one child's SNP and two maternal SNPs remained significantly associated with cerebral palsy after including all SNPs significant in the univariable analysis in a multivariable model. The $p$ values remain modest (lowest value $p=0.02$ ) and the odds ratios were also small (largest risk, odds ratio=1.53). This suggests that individually these potential genetic susceptibility SNPs for cerebral palsy are not major risk factors although it is possible that they interact with 
other SNPs and or epidemiological risk factors. Some of these potential interactions are studied a priori in this study.

\section{Interaction of mother-child genetics}

This is the first study to examine the interaction of maternal and child genetics as a risk factor for cerebral palsy. The tests conducted considered carriage of a SNP in both mother and child, where the SNP had been reported as a risk when carried by either in the univariable analysis. This approach was used to reduce the number of tests conducted from a potential 1,225 (35 SNPs $x 35$ SNPs) to 10 and these tests were based upon specific hypotheses. SNPs in the candidate panel were selected for their functionality in inflammation and thrombosis pathways and it is conceivable that perturbation of these pathways in either mother or child may result in cerebral palsy. It is likely that the contribution of each SNP to cerebral palsy outcome is small (odds ratio less that 3 ) but this risk may be potentiated when both mother and child carry a risk allele. While the tests conducted here did not uncover any significant "double hit" SNP interactions, this does not mean they do not exist and more extensive testing of all possibilities and also higher order interactions may reveal associations. A much larger sample size would be required to achieve adequate power for such tests.

\section{Interaction of genetic risk factors and infection}

While many epidemiological factors may potentially interact with genetic risk factors to increase the risk of cerebral palsy, documented maternal infection was a major factor to be investigated in this study. Infection is of particular interest because most of the candidate SNPs chosen are involved in inflammation, a biological process that can be initiated by infection; or thrombosis, a biological process that can be modulated by infection. Logistic regression uncovered several SNPs, both maternal and fetal, that significantly interacted with infection. This trend is consistent with previously reported studies that describe an increased risk of cerebral palsy when a SNP is carried together with detection of viral nucleic acids in newborn screening 


\section{Chapter 7 Multivariable Analysis}

cards ${ }^{86}$. Theoretically it would be possible to test all SNPs in our candidate panel for interaction with infection, however only those of significance $(p<0.05)$ or near significance $(p<0.1)$ in the univariable analysis were selected to reduce the number of tests conducted. It is also possible to test for interaction with all other epidemiological factors examined (e.g. gestational age, customised birth weight centile etc.) however this would generate a large number of tests, each with low power in this cohort. Furthermore, it was noted that the interactions uncovered, while highly significant in themselves (some with $\mathrm{p}<0.0005$ ), were no longer significant when added to the more complete multivariable model, suggesting that other factors are confounding the comparison between cases and controls. The interaction of infection with specific SNPs needs further study. In particular, better prospective clarification of infection is required along with placental histology on all participants which can reveal unsuspected chorioamnionitis ${ }^{149}$. A part of the current study, not included in this thesis, was the collection of Guthrie cards from the cohort and testing for PCR evidence of viral infection in these children.

\section{Combined epidemiological and genetic data}

The addition of interaction terms and genetic factors to the multivariable model did not increase the overall prediction ( $83.4 \%$, down $0.1 \%$ from $83.5 \%$ ). All interactions terms were no longer significant in the context of the other risks, while only one SNP, maternal carriage of TGF$\beta 1-509$, remained significant ( $p=0.04$, odds ratio $1.2795 \%$ confidence interval $1.01-1.60)$. While this model is below the standard required for a reliable clinical predictive tool, it does provide evidence that the maternal genome makes a small but significant contribution to cerebral palsy in the child. Further studies investigating the role of TGF- $\beta 1-509$ and its interactions are warranted, although given the effect size we report, an enormous cohort would be required to achieve adequate power.

TGF- $\beta 1$ is a cytokine with both pro-inflammatory and anti-inflammatory potential. TGFB1-509 is a promoter polymorphism, with carriage of the minor allele affecting circulating plasma 
levels of TGF- $\beta 1$ in a dose proportional manner in humans ${ }^{150}$. There is evidence that TGF- $\beta$ is expressed at the maternal-fetal interface during pregnancy ${ }^{151}$ and that high levels can result in fibrosis ${ }^{152}$. Fibrosis could potentially occur in the placenta, compromising fetal growth and increasing the risk of cerebral palsy in the offspring. This potential mechanism for the association of TGF- $\beta 1-509$ with cerebral palsy is speculative and requires further investigation.

\section{Alternative models}

Two risk factors - $<32$ weeks gestational age and Apgar score (one minute) $<4$, were common to all subtypes of cerebral palsy while a relative with cerebral palsy and $<10^{\text {th }}$ customised birth weight centile were found in three of the four subgroups. Having a relative with cerebral palsy was a particularly strong risk factor for quadriplegia $(p=0.03$, odds ratio $3.27,95 \%$ confidence interval 1.13-9.45) suggesting that a genetic aetiology may be more common in this group, although an environmental risk factor shared by the family cannot be excluded.

Considering cerebral palsy cases born at $<32$ weeks and $>36$ weeks gestational age, infection, Apgar score (one minute) $<4$ at one minute and male gender were consistently a risk. Cases born at $<32$ weeks gestational age were at risk if they were twins and in breech position, which could be expected as twins are often delivered early and are at risk of breech presentation 153. Illicit drug use and bleeding during pregnancy was associated with an increased the risk of cerebral palsy for those born at $<32$ weeks gestational age but only a small number of cases were observed. A relative with cerebral palsy was only a risk for cases delivered at term (odds ratio 2.38, 95\% confidence interval 1.40-4.06, $\mathrm{p}=0.001$ ). The combination of term delivery, quadriplegia and a relative with cerebral palsy may help identify cases of cerebral palsy most likely to have a significant genetic contribution to the condition.

The analysis of cerebral palsy subtypes and epidemiological variables presented here is exploratory. Genetic risk factors were not added to the model since the number of predictors was already high, sample sizes were small, the frequencies of many alleles was low and the 


\section{Chapter 7 Multivariable Analysis}

multivariable model of cerebral palsy (overall) showed no improvement in prediction when they were added. A much larger cohort would be required to meaningfully add the genetic and interaction factors to a model of cerebral palsy subtypes.

When considering only ante partum risk factors for cerebral palsy outcome, a further significant factor was identified - the interaction of maternal carriage of TNF- $\alpha 308$ with maternal infection (odds ratio $0.66,95 \%$ confidence interval $0.47-0.93, p=0.02$ ). This analysis reiterates the potential importance of the maternal genome and its interactions with the environment in determining cerebral palsy outcome in the child. TNF- $\alpha 308$ is known to increase circulating levels of TNF in response to infection ${ }^{60}$. This could result in a more effective maternal immune response to infections, reducing the likelihood of potentially neurotropic viruses and bacteria damaging the fetal central nervous system. This inverse association is in contrast to previous work describing a positive association of fetal TNF- $\alpha$ SNPs with cerebral palsy outcome (cerebral palsy cases born at term, quadriplegia, odds ratio $1.82,95 \%$ confidence interval 1.04-3.15; cerebral palsy cases born at less than 32 weeks gestational age, hemiplegia, heterozygous or homozygous carriage, odds ratio $1.37,95 \%$ confidence interval 1.02-5.58) ${ }^{43} 5$. Although our model identified only an interactive trend, it is possible that an increased level of circulating TNF$\alpha$ is beneficial when involved in a maternal immune response but detrimental when circulating within the fetus. The association of maternal carriage of TNF- $\alpha 308$ with cerebral palsy we have observed requires further investigation, particularly to uncover the mechanism by which it appears to provide protection against cerebral palsy in the infant.

\section{Limitations}

The cohort for this analysis included 587 cases and 1,154 controls. Multivariable logistic regression requires complete data for all variables used in the model and as a result most tests utilised a considerably smaller sample size. While this cohort is the largest assembled to date for the genetic investigation of cerebral palsy, cohort size remains a limiting factor in multivariable 


\section{Chapter $7 \quad$ Multivariable Analysis}

analysis, particularly when considering subtypes of cerebral palsy and the relatively low frequency of the SNPs examined.

The predictive power of the model in this cohort gave a small improvement on the published literature. The low sensitivity and high specificity achieved in the model are likely to be related to the 1:2 case:control ratio. Given that cerebral palsy occurs in approximately 1:500 births, high specificity and sensitivity would be required to prospectively predict cerebral palsy in a clinically useful way. The addition of genetic and interaction risk factors did not improve the predictive power of long established epidemiological risk factors. Addition of as yet unknown predictors to the model and more complex algorithms may be required to achieve utility.

More importantly, this study gave insight into the influence of the maternal genome in cerebral palsy and the possible interaction of epidemiological triggers such as infection. Infection during pregnancy may be either under or over reported. Mothers of case children are more likely to recall their pregnancy history with greater detail than mothers of control children, possibly biasing maternal reports of infection. Infection reported in the perinatal data sets rarely uses placental histology as evidence of chorioamnionitis, possibly leading to an under reporting of infection during pregnancy. Therefore, the retrospective measures of maternal infection during pregnancy we use may bias our results.

A more complete model of SNP interactions could be applied to the genetics of cerebral palsy. The analysis presented here has considered a small number of SNP interactions within mother-child pairs and previous chapters ( 4 and 5 ) have considered combinations of SNPs in the form of APOE genotypes and MBL haplotypes. It is possible to assess all SNP interactions and model all mother-child SNP interactions however the small sample size constrains this approach. The addition of paternal genetic data would provide an avenue for still further interactions that may contribute to the risk of cerebral palsy. 


\section{Chapter $7 \quad$ Multivariable Analysis}

\section{Conclusions}

This multivariable analysis included genetic, epidemiological and interaction risk factors of cerebral palsy for the first time, marginally improving on published prediction models. In addition to the well established risks of low gestational age, low Apgar score at one minute, low customised birth weight centile and infection; having a relative with cerebral palsy was also a risk factor. This may suggest a genetic contribution to cerebral palsy. Analysis of cerebral palsy subtypes identified a relative with cerebral palsy was a particularly strong risk in quadriplegias and those born at term. Maternal genotype and its interaction with infection may also play an important role in determining cerebral palsy outcome in the child. 
Chapter 8 General Discussion 
Chapter 8

General Discussion 


\section{Chapter 8 General Discussion}

\section{Introduction}

Prior to this study commencing, reports in the literature of gene association studies and cerebral palsy involved relatively small cohorts and after multiple analyses found that a variety of candidate SNPs may be associated with cerebral palsy ${ }^{85}$. There had been little investigation of the interaction of SNPs with either other SNPs or epidemiological risk factors for cerebral palsy and only one small study had considered maternal SNPs as a risk for cerebral palsy in the infant 44.

The cohort assembled for this study is the largest reported to date for the assessment of genetic risk factors for cerebral palsy. For the analysis, 587 cases and their mothers and 1,154 controls and their mothers were assessed, providing adequate power for the primary hypotheses specified a priori in chapter $2^{98}$. These hypotheses were based on the literature available at the time.

\section{Data quality and data analysis}

The case and control cohorts were examined for potential recruitment biases by comparing them with population wide data where it was available. While statistically significant differences between the cohorts and the population wide data were seen for some measures, the differences were small and unlikely to be of clinical importance. Published population data was largely epidemiological, although some SNP data was available (e.g. Factor V Leiden ${ }^{154} 10492$ ), and our results were also consistent with this published literature.

All data was systematically reviewed for entry errors (epidemiological data) and also for genotype quality. While this reduced the number of cases and controls used in the analysis, it increased the quality of the data. Few published studies of SNP associations with cerebral palsy have described in detail in silico quality control measures for genotyping data. This study assessed genotyping success rates for each candidate SNP, genotyping success rates for the DNA sample of each participating individual and Hardy Weinberg equilibrium testing in the control 


\section{Chapter 8 General Discussion}

cohort. Such assessments are critical, as genotyping assays can give biased results when genotyping data is incomplete. Few SNP association studies of cerebral palsy have reported these assessments and failure to consider them may have contributed to variable results.

Importantly, few studies of cerebral palsy have given adequate consideration to the influence of multiple testing on their results. This study uses Bonferroni correction to adjust for multiple tests. This correction errs on the conservative side and reduces false positive error but increases the chance of false negative results. Where possible, we compared the odds ratio directions from this analysis with those reported in comparable studies in the published literature. This provided a secondary and less conservative approach to the same issue, with reassuring correlation throughout the study.

While our analysis did not require 'genome wide significance levels' $\left(p<5 \times 10^{-8}\right)$ to confirm or reject SNP associations with cerebral palsy, we did require $p$ values to be less than 0.0001 to account for multiple testing. This study used the conservative Bonferroni method to correct for multiple testing. Multiple testing correction techniques that are less conservative than the Bonferroni method are available including permutation testing, false discovery rate adjustment (FDR) ${ }^{155}{ }^{156}$, Sidak ${ }^{157}$ and Holm ${ }^{158}$ corrections. These approaches are computationally intensive and are difficult to apply when a large number of subgroup analyses are conducted, as was the case in this study. Bayesian approaches may be particularly applicable to further analyses of SNP interactions, including mother-child SNP interactions, and also SNPepidemiological interactions.

\section{Univariable analysis}

\section{Child's genetics}

After correction for multiple testing only one of the child's candidate SNPs was individually associated with cerebral palsy or its subtypes. Prothrombin gene mutation remained associated with hemiplegia, in children born after 36 weeks gestational age and where there was 


\section{Chapter 8 General Discussion}

a reported antenatal infection after conservative Bonferroni correction for multiple testing $(p=0.0589$, odds ratio $4.52,95 \%$ confidence interval $1.70-12.03)$. This association is plausible, as a thrombophilic mutation could predispose to fetal brain thrombosis in the presence of a thrombophilic risk factor such as infection, resulting in "fetal stroke" and hemiplegic cerebral palsy. While several other SNP, allele and haplotype tests showed association at the level of $p=0.05$, none remained significant after Bonferroni correction. Since many of these SNPs had been tested before in comparable populations, it was possible to compare the results we observed with those previously published ${ }^{865,6,159}$. Comparing the odds ratio direction provided a less conservative confirmation that these associations had been appropriately excluded in our correction for multiple testing.

In view of the association of Prothrombin gene mutation with hemiplegia in children born after 36 weeks gestational age and where there was a reported antenatal infection, it remains plausible that genetic predisposition to a thrombotic event may increase the risk of in utero stroke, leading to hemiplegia. Further investigation of this potential causal pathway is warranted, particularly focusing on infection as a potential trigger of in utero thrombosis.

\section{Mother's genetics}

No test for association of maternal SNP carriage with cerebral palsy or its subtypes remained significant after conservative correction for multiple testing. This is the first detailed examination of maternal genetics as a risk factor for cerebral palsy and we were unable to compare odds ratio directions to other studies. Only one small study has previously investigated maternal genetics and cerebral palsy in their children and the report of Reid et al. suggested Factor V Leiden was a risk factor for cerebral palsy ${ }^{44}$. Our study was conducted in a cohort more than twice the size and included prospective genotyping of a control cohort rather than comparison to historic data as a control. The results of Reid et al. were not replicated in this analysis, possibly because they did not have a prospectively genotyped control cohort. 


\section{Chapter 8 General Discussion}

\section{Epidemiology}

The present analysis confirms many epidemiological associations with cerebral palsy that have been reported previously and extends the literature.

Infection

Maternal infection during pregnancy has previously been associated with cerebral palsy and the results of this study support the literature ${ }^{110} 111$. However, this study presents the first detailed exploration of infection type and timing as risk factors for cerebral palsy. Upper respiratory tract infections and gastrointestinal infections during pregnancy were not significantly associated with cerebral palsy. These are common infections and often a concern to pregnant women. These results may be of some reassurance to these women; however other infections, particularly later in pregnancy (e.g. fever during labour) presented an increased risk of a cerebral palsy outcome in the child. Infection during pregnancy may be either under or over reported. Mothers of case children are more likely to recall their pregnancy history with greater detail than mothers of control children, possibly biasing maternal reports of infection. Infection reported in the perinatal data sets rarely uses placental histology as evidence of chorioamnionitis, possibly leading to an under reporting of infection during pregnancy. Therefore, the retrospective measures of maternal infection during pregnancy we used may bias our results. Prospective viral and bacterial studies are required to give more insight into this potential risk factor for cerebral palsy.

\section{Family history of cerebral palsy}

Having a relative with cerebral palsy was a risk factor for subsequent cerebral palsy diagnosis in the children of this cohort and this association is supported by the literature ${ }^{11}$. This study did not have the power to assess the individual risks associated with the affect family member being a sibling or parent with cerebral palsy. All instances of participants having a sibling or parent with cerebral palsy were cases. A significantly increased risk of cerebral palsy 
was seen if there was a family history of cerebral palsy (odds ratio 1.61, 95\% confidence interval 1.12-2.32, $p=0.01$ ) suggesting a familial genetic component to some cases of cerebral palsy.

\section{Apgar score}

This study confirms the association of low Apgar score with cerebral palsy reported in the literature ${ }^{139}$. Apgar score is a measure of neonatal health in the first few minutes of life and a low score cannot be attributed as a cause of cerebral palsy. Low Apgar score as a risk for cerebral palsy suggests that infants with poor health in the first minutes of life are at increased risk of developing cerebral palsy, but it does not indicate the reason for their poor health or the period over which their health was compromised.

\section{Gestational age}

Our results concur with the literature that early delivery is a strong risk factor for cerebral palsy ${ }^{109}$. It remains unclear if early delivery is a cause of neurological impairment that results in later cerebral palsy, or if early delivery and cerebral palsy share a common origin. A case control study cannot determine if there is a direct causal relation between gestational age and cerebral palsy outcome.

\section{Small for gestational age}

Reduced size for gestational age is an important risk factor for cerebral palsy as has been previously reported in the literature ${ }^{109,116} 160$. This study used customised centiles specific to the Australian population to give an accurate measure of birth weight centile, a proxy measure of intrauterine growth restriction. The results described in this study are in line with the published literature and demonstrate increasing risk between $<10^{\text {th }},<5^{\text {th }}$ and $<3^{\text {rd }}$ customised centiles. Unfortunately length at birth was not available for calculation of the Ponderal index, a measure of late growth restriction ${ }^{119,120}$. It remains possible that some cases of growth restriction were not identified by our centiles. As an example of growth restriction that would not be detected using our measure, a baby growing on the $90^{\text {th }}$ centile for most of its pregnancy may be growth 


\section{Chapter 8 General Discussion}

restricted late in gestation and be born on the $50^{\text {th }}$ centile. Small for gestational age may be caused by a factor which also causes cerebral palsy (e.g. thrombophilia ${ }^{106}{ }^{33}{ }^{161}$ ), or small for gestational age may have an independent cause and subsequently contribute directly to cerebral palsy causation. A possible example of this is multiple birth which is associated with both small for gestational age ${ }^{162}$ and cerebral palsy. The case control methodology cannot differentiate these two scenarios.

\section{Breech}

Breech presentation at delivery has been debated as a possible risk factor for cerebral palsy ${ }^{123} 124$. This study supports the trend that it is a risk; however the sample size was limiting. Elective caesarean section delivery appeared to reduce the likelihood of cerebral palsy occurring in breech presenting infants when compared to vaginal or emergency caesarean delivery; however the numbers were small and this remains unconfirmed and controversial. It is possibly that infants with cerebral palsy have abnormal muscle tone and this contributes to breech presentation.

\section{Disappearing twin on ultrasound}

Only $10(1.7 \%)$ pregnancies with disappearing twin in early pregnancy were reported in our case cohort and $10(0.9 \%)$ pregnancies in the control cohort. Again, the numbers limit any conclusions about this putative association with cerebral palsy ${ }^{125} 126$ although the risk trend we observe is in-line with the literature.

\section{latrogenic heat in labour}

This study is the first to examine iatrogenic application of heat during labour as a potential risk for cerebral palsy. Our data show an inverse relation of iatrogenic heat in labour with cerebral palsy, in contrast to our hypothesis. This is possibly due to the cofounding effects of other complications in labour that would likely see only low risk pregnancies (i.e. those under midwife supervision) given the option of hot packs, baths or showers to reduce labour pain. 


\section{Chapter 8 General Discussion}

\section{Male gender}

Male gender was confirmed as a risk factor for cerebral palsy in our analyses. We are aware of the theoretical paper by Mage and Donner ${ }^{163}$ which, on the basis of the male preponderance in sudden infant death syndrome (SIDS), suggests there is an underlying X-linked allele that is protective of cerebral anoxia in normal babies but missing in SIDS cases. The same could be true for cerebral palsy. While Mage and Donner did not explore the role of infection in support of their theory, sex-based differences in immune responses to infection are well known, with excess male morbidity and mortality occurring in most infections ${ }^{164}$. In consideration of this and the evidence that maternal infection and chorioamnionitis are associated with cerebral palsy, it could be fruitful to compare possible X-linked alleles in our cerebral palsy cases with the controls.

\section{Multivariable analysis}

This was the first study to examine maternal-fetal SNP interactions and one of the few to consider SNP-SNP interactions in the context of cerebral palsy risk ${ }^{43}{ }^{6}$. While no significant SNPSNP interactions were identified in these limited analyses, this does not preclude the possibility that other interactions may contribute to cerebral palsy outcome. A small sample size and multiple testing constrained a more complete exploration of this matter.

SNP interactions with infection revealed highly significant associations with cerebral palsy; however these did not remain significant when added to a multivariable model including other epidemiological risk factors. This may be due to confounding, with some SNP-infection interactions contributing to preterm delivery or other risks for cerebral palsy.

The final multivariable logistic regression model in this phase of analysis identified a significant association of cerebral palsy with maternal carriage of TGF- $\beta 1-509$. This is the first reported association of TGF- $\beta 1-509$ with cerebral palsy and one of the few significant genetic risk

factors reported in a multivariable context (for others see ${ }^{87}$ ). The exact role of TGF- $\beta 1-509$ in 


\section{Chapter 8 General Discussion}

increasing the risk of cerebral palsy in the infant is unknown. TGF- $\beta 1$ is a cytokine with both proinflammatory and anti-inflammatory potential, with carriage of the TGF- $\beta 1-509$ minor allele affecting circulating plasma levels of TGF- $\beta 1$ in a dose proportional manner in humans ${ }^{150}$. There is evidence that TGF- $\beta$ is expressed at the maternal-fetal interface during pregnancy ${ }^{151}$ and that high levels can result in fibrosis ${ }^{152}$. Fibrosis in the placenta could potentially compromise fetal growth and increase the risk of cerebral palsy in the offspring. This potential mechanism for the association of TGF- $\beta 1-509$ with cerebral palsy is speculative and requires further investigation.

The multivariable analysis also confirmed a family history of cerebral palsy as a risk, when controlling for other risk factors including gestational age $<32$ weeks and $<10^{\text {th }}$ customised birth weight centile. This is an important extension of the literature as to date family history of cerebral palsy has only been considered in isolation ${ }^{11}$.

Multivariable logistic regression analysis of cerebral palsy subtypes was used to investigate potentially different roles for each risk factor in each subtype. Gestational age $<32$ weeks, Apgar score (one minute) $<4$ and size for gestational age $<10^{\text {th }}$ centile were strong risk factors for nearly all subtypes of cerebral palsy. Having a relative with cerebral palsy appeared to be of importance in quadriplegias and also in cases born at term. This observation may suggest that term born quadriplegic children are more likely than those with other cerebral palsy types to have a significant genetic contribution to their condition; although it remains possible that an environment shared by the family plays a role. The genetic contribution could be, for example, a pathogenic mutation in a single gene or a copy number variant that creates susceptibility to the disorder.

Analysis of only ante partum risk factors for cerebral palsy identified the interaction of maternal carriage of TNF- $\alpha 308$ with reported infection during pregnancy as inversely related to cerebral palsy outcome in the infant. TNF- $\alpha$ is a pro-inflammatory cytokine and the SNP TNF- $\alpha$ 308 is known to increase circulating levels of TNF- $\alpha$ in response to infection ${ }^{60}$. Maternal carriage 
of TNF- $\alpha 308$ could result in a more effective maternal immune response to infection, reducing the likelihood of potentially neurotropic virus or bacteria damaging the fetal central nervous system. This association highlights again the importance of the maternal genome in the context of cerebral palsy outcome; however the mechanism of association requires further investigation.

\section{Interpretation}

Case-control methodology cannot distinguish between association and causation and the results of this study must therefore be interpreted with caution. It is plausible that the SNPs examined in this study are not directly linked to cerebral palsy themselves, but are in linkage disequilibrium with other genetic variants that contribute to the outcome. Furthermore, a lack of association does not mean a factor has no influence on the outcome. Cerebral palsy is a complex disease with multi-factorial aetiology. A SNP under consideration may be an effect modifier of another risk factor for cerebral palsy (e.g. preterm birth) and any adjustment for the effects of this risk factor would reduce the perceived effect of the SNP on cerebral palsy. The genetic and epidemiological risk factors of cerebral palsy require further examination. The analysis presented in this thesis provides a starting point.

\section{Summary of study limitations}

While this study is currently the largest in the literature of cerebral palsy SNP association studies, its potential to detect associations is nonetheless limited by size. Achieving adequate power for the secondary aims of this study (and subsequent genome wide approaches) would require $\sim 2,500$ cases. We were unable to achieve this sample size during candidature of this thesis. A meta-analysis combining this cohort with others reported in the literature may provide sufficient statistical power.

Although there are $\sim 10$ million SNPs in the human genome, we examined only 35 candidate SNPs in this cohort, chosen based upon a priori hypotheses of a biologically plausible role in cerebral palsy causation. 


\section{Chapter 8 General Discussion}

It was important to correct for multiple testing to reduce type I error (false positive results) but the conservative Bonferroni correction used in this study, while less stringent than the accepted level for genome wide significance, may over correct and hide possible true associations (giving false negative results). Alternative corrections for multiple testing errors are available but are difficult to apply in studies analysing multiple sub-groups.

The maternal questionnaire was retrospective and as such is an imperfect recollection of events occurring during pregnancy. Recall bias may also influence these data, with mothers of case children more accurately recalling their pregnancy details than mothers of control children.

As in all retrospective case-control studies, it is almost impossible to determine the timing of events that contribute to cerebral palsy causation. Some measures e.g. Apgar score or low birth weight centiles may reflect acute, chronic or acute on chronic antenatal pathology.

\section{Summary of study strengths}

This study examined detailed genetic and epidemiological data relating to cerebral palsy risk and allowed correlation of genetic and epidemiological data. The study is the first to examine a number of SNPs in the maternal genome for possible association with cerebral palsy in the infant. The genetic and epidemiological data used in this study were subject to stringent quality control and correction was made for the bias of multiple testing.

\section{Conclusions of this study}

The univariable SNP association results of this study are in contrast to most literature published in the field, probably because of the application of conservative correction for multiple testing. It seems likely that the literature to date (including publications of this research group) has described positive correlations between SNPs and cerebral palsy because of type I error associated with multiple testing. The association reported here of Prothrombin gene mutation and hemiplegia in term delivered infants with a reported infection during pregnancy could be one exception. The univariable epidemiological associations of this study were largely supported by 
the literature. Multivariable logistic regression of SNP and epidemiological risk factors for cerebral palsy suggests that epidemiological risk factors are of most importance; although there is a small but significant contribution of maternal genetics when considered in the context of the other risk factors. Maternal TGF- $\beta 1-509$ requires more investigation to assess how it might be associated with cerebral palsy in the infant. SNP interactions and particularly maternal carriage of TNF- $\alpha 308$ interactions with infection require further investigation, examining their relationship with potentially confounding factors such as preterm birth. Genetic testing of term born children with quadriplegia and a familial history of cerebral palsy may allow the identification of specific causal mutations resulting in cerebral palsy, possibly specific to each family, but giving important insight into the origins of this condition.

\section{Future Directions}

\section{Meta-analysis}

One meta-analysis of SNP risk factors for cerebral palsy has been published to date ${ }^{165}$. Since the cohort reported in our study is the largest in the field, there may be benefits in adding this data to such a meta-analysis. The report by Wu et al. ${ }^{165}$ was published late in the drafting of this thesis and suggested that most previously published SNP associations with cerebral palsy were not significant when combined in a meta-analysis. The analysis was corrected for multiple testing using the Bonferroni method and supports the claims of this thesis. One SNP, IL-6 (odds ratio $1.79,95 \%$ confidence interval $1.44-2.22, \mathrm{p}<0.001$ ) remained significant in the study of Wu et al.. Wu et al. do not differentiate different ethnic groups in the studies they combined, and most SNPs, including IL-6, fail Hardy Weinberg equilibrium in the control group. This may explain why the results of this study, in a cohort of common ethnic background and with genotype data of satisfactory quality, are in contrast to the Wu et al. meta-analysis in relation to IL-6. Given the limited analyses conducted by Wu et al., it could be beneficial to combine the results of the present study with others examining SNPs in a Caucasian population where the genotyping data is of sufficient quality. The largest cohort available to date was described by Gibson et al. ${ }^{5,6,14,42 \text {, }}$ 


\section{Chapter 8 General Discussion}

94. The child's genetic results from the present analysis have been compared extensively to the work of Gibson et al. throughout and there has been no statistically significant correlation in odds ratio directions. It would therefore seem unlikely that adding the results of the present study to a meta-analysis would reveal any significant individual SNP associations with cerebral palsy. However, SNP-SNP interactions and SNP-epidemiological trigger interactions have still to be fully investigated.

\section{Further analyses}

While this study has described few significant individual SNP associations with cerebral palsy, this does not mean that the other SNPs examined do not contribute to the outcome. Confounding by strong risk factors for cerebral palsy, such as gestational age and size for gestational age, may be influenced by SNPs or SNP interactions and therefore indirectly contribute to cerebral palsy. Data is available to analyse each candidate SNP and SNP interaction, particularly with infection, as a potential risk factor for preterm (or very preterm) birth and also for customised birth weight below the $10^{\text {th }}$ centile. However, such an analysis is beyond the scope of the present thesis and being post hoc, would be hypothesis generating only, and open to potential multiple analyses bias, but should be performed to maximise the value of this large database.

\section{Viral studies}

This study has confirmed that maternal infection during pregnancy is a risk factor for cerebral palsy. Details of the timing and type of infection have been collected mostly by retrospective maternal questionnaire and are subject to recall bias. One alternative approach would be to test for evidence of viral nucleic acid in the stored neonatal blood spots (Guthrie card) of children participating in this study. This technique has been used in a number of contexts in the past including postulating a link between infant viral infection and cerebral palsy ${ }^{94}$. The present study requested permission to access the Guthrie card taken at the birth of each case and control and $\sim 50 \%$ have been retrieved. Methods have been refined for detection of 
viral DNA in these cards (publication in press) and testing is currently underway. While Guthrie cards provide only a limited source of DNA and are available only in some states, correlating the results of the present study with those from the Guthrie card tests may provide further insight into the purported link of in utero viral infection and cerebral palsy. Studies of other infection types, such as bacterial infections, may be required to uncover all details of the association between infection and cerebral palsy. Placental examination for signs of funisitis and chorioamnionitis can provide useful evidence of infection and is advocated, if not in all deliveries, in risk deliveries such as those with low Apgar scores, infants small for gestational age or preterm 166

\section{Alternative genetic approaches}

This study has examined 35 candidate SNPs present in mother and child as potential risk factors for cerebral palsy. An estimated 10 million SNPs are present in the human genome, leaving the vast majority unassessed. A genome wide association approach could be used in cerebral palsy to study many other SNPs that have not been investigated to date and could lead to new hypotheses of cerebral palsy causation rather than the limited infection, thrombophilic and preterm birth pathways investigated to date. Genome wide data would also allow the assessment of other types of genetic variation such as copy number variants (CNVs). CNVs have been associated with autism ${ }^{167}$, intellectual disability ${ }^{168}$ and epilepsy ${ }^{169}$ that are common in children with cerebral palsy. It is possible that CNVs are associated with cerebral palsy as well, and this line of research is being pursued by our Australian collaborative cerebral palsy research group. Genome wide data would also allow the assessment of the combined genetic contribution of all SNPs to cerebral palsy outcome ${ }^{170}$, an important test which may or may not support the hypothesis of genetic susceptibility to cerebral palsy.

The results of this study also recommend the close examination of quadriplegic children born at term with a familial history of cerebral palsy. Examination of such families, particularly 


\section{Chapter 8 General Discussion}

where siblings are affected, by massively parallel sequencing may be feasible in the near future given rapidly falling costs. It is possible that new genetic variants, likely to be the cause of cerebral palsy, would be uncovered using this approach. This thesis has stimulated such a study and families with more than one member with cerebral palsy have been identified from the cohort described in this thesis allowing in depth familial studies to commence.

\section{Bio-banking}

All strategies of genetic research require a large and well characterised cohort in order to achieve suitable levels of statistical power. Establishing a bio-bank of genetic material from families who have a child with cerebral palsy will hold the key to future genetic research efforts. Currently no such bio-bank for cerebral palsy samples exists. The cohort described in this thesis is the largest collection of DNA from children with cerebral palsy available to date, and this is far from adequate, with sample size constraining even the basic analyses outlined in this thesis. The DNA was collected using buccal swabs and is not suitable in quantity or quality for genome wide or sequencing approaches. Ideally, a bio-bank would collect blood from families, storing both whole blood and immortalised cell lines allowing an 'endless' supply of DNA. Thus our group is establishing a bio-bank of blood derived DNA, linked to epidemiological data similar to that collected in this study. DNA collection is complemented by detailed family histories, pregnancy histories and cerebral palsy diagnosis information, and may expand to include radiological imaging. Such a venture is clearly beyond the scope of this thesis and requires an ongoing financial commitment and careful curating over several years before the benefits are evident. The candidate SNP association study described in this thesis has been a catalyst for this cerebral palsy bio-bank and for further studies into structural alterations in both familial and de novo cases of cerebral palsy. In the near term, it may also be beneficial for existing cerebral palsy registers in Australia and internationally to commence collecting information about cerebral palsy family history. These registers are already in place and operational. The addition of a small 
number of extra questions about family history would allow identification of families most suitable for genetic investigation.

\section{Future applications of this research}

This candidate SNP association study has helped focus new research on familial clusters of cerebral palsy and other types of genetic variation. It has stimulated the formation of a large bio-bank of DNA from families who have a child with cerebral palsy for national and international collaborative studies. The network of Australian collaborators and families built during this project can be fostered and maintained for larger genetic studies. The large amounts of epidemiological information on each case, including some potential environmental triggers, may help identify their interaction with susceptibility genes identified in this and future studies.

It is likely that gradually increasing numbers of genetic alterations will be identified in cerebral palsy cases. An understanding of these genetic alterations and their interactions with environmental triggers may increase our understanding of the causes of cerebral palsy. In the future it may be possible to intervene and prevent cerebral palsy. Interventions utilising genetic data could include preconception or pregnancy genetic counselling, pre-implantation genetic testing during assisted reproduction techniques, gene therapy if it is further developed, pharmacotherapies specific to the genetic profile of at risk pregnant women and possible prenatal immunisation if specific viruses are associated with cerebral palsy. A substantial amount of further work is required before genetic studies will be able to contribute to the goal of clinical interventions for the prevention of cerebral palsy. 


\section{References}

1. Rosenbaum $\mathrm{P}$, Paneth $\mathrm{N}$, Leviton $\mathrm{A}$, et al. A report: the definition and classification of cerebral palsy April 2006. Dev Med Child Neurol Suppl. 2007;109:8-14.

2. Strijbis EM, Oudman I, van Essen P, MacLennan AH. Cerebral palsy and the application of the international criteria for acute intrapartum hypoxia. Obstet Gynecol. 2006;107(6):1357-1365.

3. Gibson CS, MacLennan AH, Goldwater PN, Dekker GA. Antenatal causes of cerebral palsy: associations between inherited thrombophilias, viral and bacterial infection, and inherited susceptibility to infection. Obstet Gynecol Surv. 2003;58(3):209-220.

4. Nelson KB, Ellenberg JH. Antecedents of cerebral palsy. Multivariate analysis of risk. N Engl J Med. 1986;315(2):81-86.

5. Gibson CS, MacLennan AH, Goldwater PN, Haan EA, Priest K, Dekker GA. The association between inherited cytokine polymorphisms and cerebral palsy. Am J Obstet Gynecol. 2006;194(3):674 e671-611.

6. Gibson CS, MacLennan AH, Goldwater PN, Haan EA, Priest K, Dekker GA. Mannose-binding lectin haplotypes may be associated with cerebral palsy only after perinatal viral exposure. Am J Obstet Gynecol. 2008;198(5):509 e501-508.

7. Grether JK, Nelson KB. Maternal infection and cerebral palsy in infants of normal birth weight. JAMA. 1997;278(3):207-211.

8. Vigneswaran R, Aitchison SJ, McDonald HM, Khong TY, Hiller JE. Cerebral palsy and placental infection: a case-cohort study. BMC Pregnancy Childbirth. 2004;4(1):1. 


\section{References}

9. Nelson KB, Grether JK. Causes of cerebral palsy. Curr Opin Pediatr. $1999 ; 11(6): 487-491$.

10. Nelson KB, Lynch JK. Stroke in newborn infants. Lancet Neurol. 2004;3(3):150158.

11. Hemminki K, Li X, Sundquist K, Sundquist J. High familial risks for cerebral palsy implicate partial heritable aetiology. Paediatr Perinat Epidemiol. 2007;21(3):235-241.

12. Kalafatis M, Bertina RM, Rand MD, Mann KG. Characterization of the molecular defect in factor VR506Q. J Biol Chem. 1995;270(8):4053-4057.

13. Walker I. Thrombophilia in pregnancy. J Clin Pathol. 2000;53:573-580.

14. Gibson CS, MacLennan AH, Hague WM, et al. Associations between inherited thrombophilias, gestational age, and cerebral palsy. Am J Obstet Gynecol. 2005;193(4):1437.

15. Goyette P, Sumner JS, Milos R, et al. Human methylenetetrahydrofolate reductase: isolation of cDNA, mapping and mutation identification. Nat Genet. 1994;7(2):195200.

16. Christen WG, Ajani UA, Glynn RJ, Hennekens $\mathrm{CH}$. Blood levels of homocysteine and increased risks of cardiovascular disease: causal or casual? Arch Intern Med. $2000 ; 160(4): 422-434$.

17. Wang G, Woo CW, Sung FL, Siow YL, O K. Increased monocyte adhesion to aortic endothelium in rats with hyperhomocysteinemia: role of chemokine and adhesion molecules. Arterioscler Thromb Vasc Biol. 2002;22(11):1777-1783.

18. Rodgers GM, Kane WH. Activation of endogenous factor $\mathrm{V}$ by a homocysteineinduced vascular endothelial cell activator. J Clin Invest. 1986;77(6):1909-1916.

19. Welch G, Loscalzo J. Homocysteine and atherothrombosis. $N$ Engl J Med. 1998;338:1042-1051. 


\section{References}

20. Zetterberg $\mathrm{H}$, Regland $\mathrm{B}$, Palmer $\mathrm{M}$, et al. Increased frequency of combined methylenetetrahydrofolate reductase C677T and A1298C mutated alleles in spontaneously aborted embryos. Eur J Hum Genet. 2002;10(2):113-118.

21. Quek SC, Low PS, Saha N, Heng CK. The effects of three factor VII polymorphisms on factor VII coagulant levels in healthy Singaporean Chinese, Malay and Indian newborns. Ann Hum Genet. 2006;70(Pt 6):951-957.

22. Hunault M, Arbini AA, Lopaciuk S, Carew JA, Bauer KA. The Arg353GIn polymorphism reduces the level of coagulation factor VII. In vivo and in vitro studies. Arterioscler Thromb Vasc Biol. 1997;17(11):2825-2829.

23. Chudakova DA, Minushkina LO, Zateishchikov DA, Nosik VV. [Association of polymorphic marker G(-455)A of gene FGB with coronary artery disease]. Genetika. 2004;40(10):1406-1409.

24. Thompson SG, Kienast J, Pyke SD, Haverkate F, van de Loo JC. Hemostatic factors and the risk of myocardial infarction or sudden death in patients with angina pectoris. European Concerted Action on Thrombosis and Disabilities Angina Pectoris Study Group. N Engl J Med. $1995 ; 332(10): 635-641$.

25. Dawson SJ, Wiman B, Hamsten A, Green F, Humphries S, Henney AM. The two allele sequences of a common polymorphism in the promoter of the plasminogen activator inhibitor-1 (PAI-1) gene respond differently to interleukin-1 in HepG2 cells. J Biol Chem. $1993 ; 268(15): 10739-10745$.

26. Henry M, Chomiki N, Scarabin PY, et al. Five frequent polymorphisms of the PAI-1 gene: lack of association between genotypes, PAl activity, and triglyceride levels in a healthy population. Arterioscler Thromb Vasc Biol. 1997;17(5):851-858. 


\section{References}

27. Medina P, Navarro S, Estelles A, et al. Contribution of polymorphisms in the endothelial protein $\mathrm{C}$ receptor gene to soluble endothelial protein $\mathrm{C}$ receptor and circulating activated protein C levels, and thrombotic risk. Thromb Haemost. 2004;91(5):905-911.

28. Nelson KB. Perinatal ischemic stroke. Stroke. 2007;38(2 Suppl):742-745.

29. Robertson L, Wu O, Langhorne $\mathrm{P}$, et al. Thrombophilia in pregnancy: a systematic review. Br J Haematol. 2006;132(2):171-196.

30. Jacobsson B, Ahlin K, Francis A, Hagberg G, Hagberg H, Gardosi J. Cerebral palsy and restricted growth status at birth: population-based case-control study. BJOG. 2008;115(10):1250-1255.

31. Thorngren-Jerneck K, Herbst A. Perinatal factors associated with cerebral palsy in children born in sweden. Obstet Gynecol. 2006;108(6):1499-1505.

32. Dekker G, de Vries J, Doelitzsch P, et al. Underlying disorders associated with severe early-onset preeclampsia. Am J Obstet Gynecol. 1995;173:1042-1048.

33. Kist WJ, Janssen NG, Kalk JJ, Hague WM, Dekker GA, de Vries JI. Thrombophilias and adverse pregnancy outcome - A confounded problem! Thromb Haemost. 2008;99(1):77-85.

34. Scantlebury MH, David M, Carmant L. Association between factor $\mathrm{V}$ Leiden mutation and the hemiconvulsion, hemiplegia, and epilepsy syndrome: report of two cases. J Child Neurol. 2002;17(9):713-717.

35. Curry CJ, Bhullar S, Holmes J, Delozier CD, Roeder ER, Hutchison HT. Risk factors for perinatal arterial stroke: a study of 60 mother-child pairs. Pediatr Neurol. 2007;37(2):99-107.

36. Lynch JK, Nelson KB, Curry CJ, Grether JK. Cerebrovascular disorders in children with the factor V Leiden mutation. J Child Neurol. 2001;16(10):735-744.

37. Halliday J, Reddihough D, Byron K, Ekert H, Ditchfield M. Hemiplegic cerebral palsy and the factor $V$ Leiden mutation. J Med Genet. 2000;37:787-789. 


\section{References}

38. Senbil N, Yuksel D, Yilmaz D, Gurer YK. Prothrombotic risk factors in children with hemiplegic cerebral palsy. Pediatr Int. 2007;49(5):600-602.

39. Smith RA, Skelton $M$, Howard $M$, Levene $M$. Is thrombophilia a factor in the development of hemiplegic cerebral palsy? Dev Med Child Neurol. 2001;43(11):724-730.

40. Fattal-Valevski A, Kenet G, Kupferminc MJ, et al. Role of thrombophilic risk factors in children with non-stroke cerebral palsy. Thromb Res. 2005;116(2):133-137.

41. Yehezkely-Schildkraut $\mathrm{V}$, Kutai $\mathrm{M}$, Hugeirat $\mathrm{Y}$, et al. Thrombophilia: a risk factor for cerebral palsy? Isr Med Assoc J. 2005;7(12):808-811.

42. Gibson CS, Maclennan AH, Dekker GA, et al. Candidate genes and cerebral palsy: a population-based study. Pediatrics. 2008;122(5):1079-1085.

43. Nelson KB, Dambrosia JM, lovannisci DM, Cheng S, Grether JK, Lammer E. Genetic polymorphisms and cerebral palsy in very preterm infants. Pediatr Res. 2005;57(4):494499.

44. Reid S, Halliday J, Ditchfield M, et al. Factor V Leiden mutation: a contributory factor for cerebral palsy? Dev Med Child Neurol. 2006;48(1):14-19.

45. Holm PI, Hustad S, Ueland PM, Vollset SE, Grotmol T, Schneede J. Modulation of the homocysteine-betaine relationship by methylenetetrahydrofolate reductase 677 C->t genotypes and B-vitamin status in a large-scale epidemiological study. J Clin Endocrinol Metab. 2007;92(4):1535-1541.

46. Gotsch F, Romero R, Kusanovic JP, et al. The fetal inflammatory response syndrome. Clin Obstet Gynecol. 2007;50(3):652-683.

47. Thorarensen O, Ryan S, Hunter J, Younkin DP. Factor V Leiden mutation: an unrecognized cause of hemiplegic cerebral palsy, neonatal stroke, and placental thrombosis. Ann Neurol. 1997;42(3):372-375. 


\section{References}

48. Harum KH, Hoon AH, Jr., Kato GJ, Casella JF, Breiter SN, Johnston MV. Homozygous factor- $\mathrm{V}$ mutation as a genetic cause of perinatal thrombosis and cerebral palsy. Dev Med Child Neurol. 1999;41(11):777-780.

49. Steiner M, Hodes MZ, Shreve M, Sundberg S, Edson JR. Postoperative stroke in a child with cerebral palsy heterozygous for factor $\mathrm{V}$ Leiden. J Pediatr Hematol Oncol. $2000 ; 22(3): 262-264$.

50. Vagiakou EA, Voudris KA, Dimitriou Y, Skardoutsou A, Mastroyianni S. Different additional risk factors for cerebral infarctions associated with the factor $\mathrm{V}$ Leiden mutation in a family. J Child Neurol. 2006;21(10):903-907.

51. Saunders AM, Strittmatter WJ, Schmechel D, et al. Association of apolipoprotein E allele epsilon 4 with late-onset familial and sporadic Alzheimer's disease. Neurology. 1993;43(8):1467-1472.

52. McCarron MO, Delong D, Alberts MJ. APOE genotype as a risk factor for ischemic cerebrovascular disease: a meta-analysis. Neurology. 1999;53(6):1308-1311.

53. Meirelles Kalil Pessoa de B, Rodrigues CJ, de Barros TE, Bevilacqua RG. Presence of apolipoprotein E epsilon4 allele in cerebral palsy. J Pediatr Orthop. 2000;20(6):786-789.

54. Kuroda MM, Weck ME, Sarwark JF, Hamidullah A, Wainwright MS. Association of apolipoprotein E genotype and cerebral palsy in children. Pediatrics. 2007;119(2):306-313.

55. McMichael GL, Gibson CS, Goldwater PN, et al. Association between Apolipoprotein E genotype and cerebral palsy is not confirmed in a Caucasian population. Hum Genet. 2008;124(4):411-416.

56. Srinivasan SR, Ehnholm C, Elkasabany A, Berenson G. Influence of apolipoprotein E polymorphism on serum lipids and lipoprotein changes from childhood to adulthood: the Bogalusa Heart Study. Atherosclerosis. 1999;143(2):435-443. 


\section{References}

57. Kilpinen S, Hulkkonen J, Wang XY, Hurme M. The promoter polymorphism of the interleukin-6 gene regulates interleukin-6 production in neonates but not in adults. Eur Cytokine Netw. 2001;12(1):62-68.

58. Chauhan M, McGuire W. Interleukin-6 (-174C) polymorphism and the risk of sepsis in very low birth weight infants: meta-analysis. Arch Dis Child Fetal Neonatal Ed. 2008;93(6):F427-429.

59. Ozaki K, Ohnishi Y, lida A, et al. Functional SNPs in the lymphotoxin-alpha gene that are associated with susceptibility to myocardial infarction. Nat Genet. 2002;32(4):650-654.

60. Kroeger KM, Carville KS, Abraham LJ. The -308 tumor necrosis factor-alpha promoter polymorphism effects transcription. Mol Immunol. 1997;34(5):391-399.

61. McGuire W, Hill AV, Allsopp CE, Greenwood BM, Kwiatkowski D. Variation in the TNF-alpha promoter region associated with susceptibility to cerebral malaria. Nature. 1994;371(6497):508-510.

62. Ates O, Musellim B, Ongen G, Topal-Sarikaya A. Interleukin-10 and tumor necrosis factor-alpha gene polymorphisms in tuberculosis. J Clin Immunol. 2008;28(3):232-236.

63. Lazarus $\mathrm{M}$, Hajeer $\mathrm{AH}$, Turner $\mathrm{D}$, et al. Genetic variation in the interleukin 10 gene promoter and systemic lupus erythematosus. J Rheumatol. 1997;24(12):2314-2317.

64. Moore KW, O'Garra A, de Waal Malefyt R, Vieira P, Mosmann TR. Interleukin-10. Annu Rev Immunol. 1993;11:165-190.

65. Pociot F, Molvig J, Wogensen L, Worsaae H, Nerup J. A Taql polymorphism in the human interleukin-1 beta (IL-1 beta) gene correlates with IL-1 beta secretion in vitro. Eur J Clin Invest. Jun 1992;22(6):396-402. 


\section{References}

66. Heinzmann A, Ahlert I, Kurz T, Berner R, Deichmann KA. Association study suggests opposite effects of polymorphisms within IL8 on bronchial asthma and respiratory syncytial virus bronchiolitis. J Allergy Clin Immunol. 2004;114(3):671-676.

67. Yoon $\mathrm{BH}$, Romero R, Kim CJ, et al. High expression of tumor necrosis factor-alpha and interleukin-6 in periventricular leukomalacia. Am J Obstet Gynecol. 1997;177(2):406-411.

68. Jacobsson B, Hagberg G, Hagberg B, Ladfors L, Niklasson A, Hagberg H. Cerebral palsy in preterm infants: a population-based case-control study of antenatal and intrapartal risk factors. Acta Paediatr. 2002;91(8):946-951.

69. Bashiri A, Burstein E, Mazor M. Cerebral palsy and fetal inflammatory response syndrome: A review. Journal of Perinatal Medicine. 2006;34(1):5-12.

70. Braun JS, Hoffmann O, Schickhaus M, et al. Pneumolysin causes neuronal cell death through mitochondrial damage. Infect Immun. 2007;75(9):4245-4254.

71. Dickinson J. Viral Teratology. In: Gonik B, ed. Viral Diseases in Pregnancy: Springer-Verlag; 1994.

72. Harding DR, Dhamrait S, Whitelaw A, Humphries SE, Marlow N, Montgomery HE. Does Interleukin-6 Genotype Influence Cerebral Injury or Developmental Progress After Preterm Birth? Pediatrics. 10 2004;114(4):941-947.

73. Dordelmann M, Kerk J, Dressler F, et al. Interleukin-10 high producer allele and ultrasound-defined periventricular white matter abnormalities in preterm infants: a preliminary study. Neuropediatrics. 2006;37(3):130-136.

74. Zaretsky MV, Alexander JM, Byrd W, Bawdon RE. Transfer of inflammatory cytokines across the placenta. Obstet Gynecol. 2004;103(3):546-550.

75. Nelson KB, Willoughby RE. Overview: infection during pregnancy and neurologic outcome in the child. Ment Retard Dev Disabil Res Rev. 2002;8(1):1-2. 


\section{References}

76. Hoffman M, Cooper ST. Thrombin enhances monocyte secretion of tumor necrosis factor and interleukin-1 beta by two distinct mechanisms. Blood Cells Mol Dis. $1995 ; 21(2): 156-167$.

77. Sabroe I, Dower SK, Whyte MK. The role of Toll-like receptors in the regulation of neutrophil migration, activation, and apoptosis. Clin Infect Dis. 2005;41 Suppl 7:S421-426.

78. Arbour NC, Lorenz E, Schutte BC, et al. TLR4 mutations are associated with endotoxin hyporesponsiveness in humans. Nat Genet. 2000;25(2):187-191.

79. Takahashi M, Mori S, Shigeta S, Fujita T. Role of MBL-associated serine protease (MASP) on activation of the lectin complement pathway. Adv Exp Med Biol. 2007;598:93-104.

80. de Messias-Reason IJ, Boldt AB, Moraes Braga AC, et al. The association between mannan-binding lectin gene polymorphism and clinical leprosy: new insight into an old paradigm. J Infect Dis. 2007;196(9):1379-1385.

81. Cipollone F, Toniato E, Martinotti S, et al. A polymorphism in the cyclooxygenase 2 gene as an inherited protective factor against myocardial infarction and stroke. JAMA. 2004;291(18):2221-2228.

82. Harding DR, Humphries SE, Whitelaw A, Marlow N, Montgomery HE. Cognitive outcome and cyclo-oxygenase-2 gene (-765 G/C) variation in the preterm infant. Arch Dis Child Fetal Neonatal Ed. 2007;92(2):F108-112.

83. Papafili A, Hill MR, Brull DJ, et al. Common promoter variant in cyclooxygenase-2 represses gene expression: evidence of role in acute-phase inflammatory response. Arterioscler Thromb Vasc Biol. 2002;22(10):1631-1636.

84. Atochin DN, Demchenko IT, Astern J, Boso AE, Piantadosi CA, Huang PL. Contributions of endothelial and neuronal nitric oxide synthases to cerebrovascular responses to hyperoxia. J Cereb Blood Flow Metab. 2003;23(10):1219-1226. 


\section{References}

85. O'Callaghan ME, MacLennan AH, Haan EA, Dekker G. The genomic basis of cerebral palsy: a HuGE systematic literature review. Hum Genet. 2009;126(1):149-172.

86. Djukic M, Gibson CS, Maclennan AH, et al. Genetic susceptibility to viral exposure may increase the risk of cerebral palsy. Aust N Z J Obstet Gynaecol. 2009;49(3):247-253.

87. Wu YW, Croen LA, Torres AR, Van De Water J, Grether JK, Hsu NN. Interleukin-6 genotype and risk for cerebral palsy in term and near-term infants. Ann Neurol. 2009;66(5):663670.

88. Braga LW, Borigato EV, Speck-Martins CE, et al. Apolipoprotein E genotype and cerebral palsy. Dev Med Child Neurol. 2010;52(7):666-671.

89. Cheng $\mathrm{X}$, Li T, Wang $\mathrm{H}$, et al. Methylenetetrahydrofolate reductase gene polymorphisms and cerebral palsy in Chinese infants. J Hum Genet. 2011;56(1):17-21.

90. McMichael GL, Gibson CS, O'Callaghan ME, et al. DNA from buccal swabs suitable for high-throughput SNP multiplex analysis. J Biomol Tech. 2009;20(5):232-235.

91. Dammann O, Allred EN, Veelken N. Increased risk of spastic diplegia among very low birth weight children after preterm labor or prelabor rupture of membranes. J Pediatr. 1998;132(3 Pt 1):531-535.

92. Gibson CS, MacLennan AH, Rudzki Z, et al. The prevalence of inherited thrombophilias in a Caucasian Australian population. Pathology. 2005;37(2):160-163.

93. Gibson CS, Goldwater PN, MacLennan AH, Haan EA, Priest K, Dekker GA. Fetal exposure to herpesviruses may be associated with pregnancy-induced hypertensive disorders and preterm birth in a Caucasian population. Bjog. 2008;115(4):492-500.

94. Gibson CS, MacLennan AH, Goldwater PN, Haan EA, Priest K, Dekker GA. Neurotropic viruses and cerebral palsy: population based case-control study. BMJ. 2006;332(7533):76-80. 


\section{References}

95. Sullivan PLE. Australia's mothers and babies 2007. Perinatal statistics series no.

23. Cat. no. PER 48. Sydney: AlHW National Perinatal Statistics Unit. 2009.

96. Annual Report of The Australian Cerebral Palsy Register. 2009.

97. Wigginton JE, Cutler DJ, Abecasis GR. A note on exact tests of Hardy-Weinberg equilibrium. Am J Hum Genet. 2005;76(5):887-893.

98. O'Callaghan ME, Maclennan AH, Gibson CS, et al. The Australian cerebral palsy research study - Protocol for a national collaborative study investigating genomic and clinical associations with cerebral palsy. J Paediatr Child Health. 2010.

99. Purcell S, Neale B, Todd-Brown K, et al. PLINK: a tool set for whole-genome association and population-based linkage analyses. Am J Hum Genet. 2007;81(3):559-575.

100. Painter JN, Anderson CA, Nyholt DR, et al. Genome-wide association study identifies a locus at 7p15.2 associated with endometriosis. Nat Genet. 2010.

101. Kraft P. Curses--winner's and otherwise--in genetic epidemiology. Epidemiology. 2008;19(5):649-651; discussion 657-648.

102. Colhoun HM, McKeigue PM, Davey Smith G. Problems of reporting genetic associations with complex outcomes. Lancet. 2003;361(9360):865-872.

103. Crider KS, Whitehead N, Buus RM. Genetic variation associated with preterm birth: a HuGE review. Genet Med. 2005;7(9):593-604.

104. Said JM, Brennecke SP, Moses EK, et al. The prevalence of inherited thrombophilic polymorphisms in an asymptomatic Australian antenatal population. Aust $N Z \mathrm{~J}$ Obstet Gynaecol. 2008;48(6):536-541.

105. Alfirevic Z, Roberts D, Martlew V. How strong is the association between maternal thrombophilia and adverse pregnancy outcome? A systematic review. Eur J Obstet Gynecol Reprod Biol. 2002;101(1):6-14. 


\section{References}

106. Kupferminc M, Eldor A, Steinman N, et al. Increased frequency of genetic thrombophilia in women with complications of pregnancy. New England Journal of Medicine. $1999 ; 340(1): 9-13$

107. Stanley FJ, Watson L. Methodology of a cerebral palsy register. The Western Australian experience. Neuroepidemiology. 1985;4(3):146-160.

108. Nelson KB, Ellenberg JH. Epidemiology of cerebral palsy. Adv Neurol. 1978;19:421-435.

109. Stanley F, Blair E, Alberman E. Cerebral Palsies: Epidemiology and Causal Pathways. Vol 151. London: Mac Keith Press; 2000.

110. Neufeld MD, Frigon C, Graham AS, Mueller BA. Maternal infection and risk of cerebral palsy in term and preterm infants. J Perinatol. 2005;25(2):108-113.

111. Gilbert WM, Jacoby BN, Xing G, Danielsen B, Smith LH. Adverse obstetric events are associated with significant risk of cerebral palsy. Am J Obstet Gynecol. 2010;203(4):328 e321325.

112. Yokoyama Y, Shimizu T, Hayakawa K. Prevalence of cerebral palsy in twins, triplets and quadruplets. Int J Epidemiol. 1995;24(5):943-948.

113. Nelson KB, Ellenberg JH. Antecedents of cerebral palsy. I. Univariate analysis of risks. Am J Dis Child. 1985;139(10):1031-1038.

114. Shatrov JG, Birch SC, Lam LT, Quinlivan JA, McIntyre S, Mendz GL. Chorioamnionitis and cerebral palsy: a meta-analysis. Obstet Gynecol. 2010;116(2 Pt 1):387-392.

115. Sun Y, Vestergaard M, Christensen J, Nahmias AJ, Olsen J. Prenatal exposure to maternal infections and epilepsy in childhood: a population-based cohort study. Pediatrics. 2008;121(5):e1100-1107. 


\section{References}

116. Wu YW, Croen LA, Shah SJ, Newman TB, Najjar DV. Cerebral palsy in a term population: risk factors and neuroimaging findings. Pediatrics. 2006;118(2):690-697.

117. Blair E, Stanley F. Intrauterine growth and spastic cerebral palsy. I. Association with birth weight for gestational age. Am J Obstet Gynecol. 1990;162(1):229-237.

118. Jarvis S, Glinianaia SV, Torrioli MG, et al. Cerebral palsy and intrauterine growth in single births: European collaborative study. Lancet. 2003;362(9390):1106-1111.

119. Landmann E, Reiss I, Misselwitz B, Gortner L. Ponderal index for discrimination between symmetric and asymmetric growth restriction: percentiles for neonates from 30 weeks to 43 weeks of gestation. J Matern Fetal Neonatal Med. 2006;19(3):157-160.

120. Fay RA, Dey PL, Saadie CM, Buhl JA, Gebski VJ. Ponderal index: a better definition of the 'at risk' group with intrauterine growth problems than birth-weight for gestational age in term infants. Aust N Z J Obstet Gynaecol. 1991;31(1):17-19.

121. Yue SJ. Multiple births in cerebral palsy. Am J Phys Med. Apr 1955;34(2):335-341.

122. Report of the Australian Cerebral Palsy Register, Birth Years 1993-2003, Dec 2009.

123. Andersen GL, Irgens LM, Skranes J, Salvesen KA, Meberg A, Vik T. Is breech presentation a risk factor for cerebral palsy? A Norwegian birth cohort study. Dev Med Child Neurol. 2009;51(11):860-865.

124. Vukojevic M, Soldo I, Granic D. Risk factors associated with cerebral palsy in newborns. Coll Antropol. 2009;33 Suppl 2:199-201.

125. Newton R, Casabonne D, Johnson A, Pharoah P. A case-control study of vanishing twin as a risk factor for cerebral palsy. Twin Res. 2003;6(2):83-84.

126. Taylor CL, de Groot J, Blair EM, Stanley FJ. The risk of cerebral palsy in survivors of multiple pregnancies with cofetal loss or death. Am J Obstet Gynecol. 2009;201(1):41 e41-46. 


\section{References}

127. Impey L, Greenwood C, MacQuillan K, Reynolds M, Sheil O. Fever in labour and neonatal encephalopathy: a prospective cohort study. Bjog. 2001;108(6):594-597.

128. Schulzke SM, Rao S, Patole SK. A systematic review of cooling for neuroprotection in neonates with hypoxic ischemic encephalopathy - are we there yet? $B M C$ Pediatr. 2007;7:30.

129. Jonas O, Stern LM, Macharper T. A South Australian study of pregnancy and birth risk factors associated with cerebral palsy. Int J Rehabil Res. 1989;12(2):159-166.

130. Hagberg B, Hagberg G, Olow I, van Wendt L. The changing panorama of cerebral palsy in Sweden. VII. Prevalence and origin in the birth year period 1987-90. Acta Paediatr. $1996 ; 85(8): 954-960$.

131. Suvanand S, Kapoor SK, Reddaiah VP, Singh U, Sundaram KR. Risk factors for cerebral palsy. Indian J Pediatr. 1997;64(5):677-685.

132. Walstab J, Bell R, Reddihough D, Brennecke S, Bessell C, Beischer N. Antenatal and intrapartum antecedents of cerebral palsy: a case-control study. Aust N Z J Obstet Gynaecol. $2002 ; 42(2): 138-146$.

133. Wang T, Zhang J, Lu X, Xi W, Li Z. Maternal early pregnancy body mass index and risk of preterm birth. Arch Gynecol Obstet. 2010.

134. Nelson KB, Grether JK. Potentially asphyxiating conditions and spastic cerebral palsy in infants of normal birth weight. Am J Obstet Gynecol. 1998;179(2):507-513.

135. Graham EM, Ruis KA, Hartman AL, Northington FJ, Fox HE. A systematic review of the role of intrapartum hypoxia-ischemia in the causation of neonatal encephalopathy. Am J Obstet Gynecol. 2008;199(6):587-595.

136. Abel EL. Cerebral palsy and alcohol consumption during pregnancy: is there a connection? Alcohol Alcohol. 2010;45(6):592-594. 


\section{References}

137. Stelmach T, Pisarev H, Talvik T. Ante- and perinatal factors for cerebral palsy: case-control study in Estonia. J Child Neurol. 2005;20(8):654-660.

138. Hong T, Paneth N. Maternal and infant thyroid disorders and cerebral palsy. Semin Perinatol. 2008;32(6):438-445.

139. Nelson KB, Ellenberg JH. Apgar scores as predictors of chronic neurologic disability. Pediatrics. 1981;68(1):36-44.

140. Lie KK, Groholt EK, Eskild A. Association of cerebral palsy with Apgar score in low and normal birthweight infants: population based cohort study. BMJ. 2010;341:c4990.

141. Tioseco JA, Aly H, Essers J, Patel K, El-Mohandes AA. Male sex and intraventricular hemorrhage. Pediatr Crit Care Med. 2006;7(1):40-44.

142. Hassold T, Chen N, Funkhouser J, et al. A cytogenetic study of 1000 spontaneous abortions. Ann Hum Genet. 1980;44(Pt 2):151-178.

143. Hassold TJ. A cytogenetic study of repeated spontaneous abortions. Am J Hum Genet. 1980;32(5):723-730.

144. Preston F, Rosendaal F, Walker I, al e. Increased fetal loss in women with heritable thrombophilia. Lancet. 1996;348:913-916.

145. Himpens E, Oostra A, Franki I, Van Maele G, Vanhaesebrouck P, Van den Broeck C. Predictability of cerebral palsy and its characteristics through neonatal cranial ultrasound in a high-risk NICU population. Eur J Pediatr. 2010;169(10):1213-1219.

146. Polivka BJ, Nickel JT, Wilkins JR, 3rd. Cerebral palsy: evaluation of a model of risk. Res Nurs Health. 1993;16(2):113-122.

147. Beaino G, Khoshnood B, Kaminski M, et al. Predictors of cerebral palsy in very preterm infants: the EPIPAGE prospective population-based cohort study. Dev Med Child Neurol. 2010;52(6):e119-125. 


\section{References}

148. Blair E, Stanley F. When can cerebral palsy be prevented? The generation of causal hypotheses by multivariate analysis of a case-control study. Paediatr Perinat Epidemiol. 1993;7(3):272-301.

149. Jeffrey IJ. The critical role of perinatal pathology. Bjog. 2003;110 Suppl 20:128130.

150. Grainger DJ, Heathcote $\mathrm{K}$, Chiano $\mathrm{M}$, et al. Genetic control of the circulating concentration of transforming growth factor type beta1. Hum Mol Genet. 1999;8(1):93-97.

151. Graham CH, Lysiak JJ, McCrae KR, Lala PK. Localization of transforming growth factor-beta at the human fetal-maternal interface: role in trophoblast growth and differentiation. Biol Reprod. 1992;46(4):561-572.

152. Border WA, Ruoslahti E. Transforming growth factor-beta in disease: the dark side of tissue repair. J Clin Invest. 1992;90(1):1-7.

153. Maksimovic J, Radovanovic P, Petakovic S. [Breech presentation in multiple pregnancy]. Med Pregl. 1989;42(3-4):141-144.

154. Pecheniuk NM, Marsh NA, Walsh TP, Dale JL. Use of first nucleotide change technology to determine the frequency of factor $V$ Leiden in a population of Australian blood donors. Blood Coagul Fibrinolysis. 1997;8(8):491-495.

155. Benjamini YaH, Y. Controlling the false discovery rate: a practical and powerful approach to multiple testing. Journal of the Royal Statistical Society, Series B (Methodological). 1995;57(1):289-300.

156. Benjamini YY, Daniel. The control of the false discovery rate in multiple testing under dependency. Annals of Statistics. 2001;29(4):1165-1188.

157. Sidak Z. Rectangular Confidence Regions for the Means of Multivariate Normal Distributions. American Statistical Association. 1967;62(626-633). 


\section{References}

158. Holm S. A simple sequentially rejective multiple test procedure. Scand. J. Statist. 1979 6:65-70.

159. Gibson CS, MacLennan AH, Janssen NG, et al. Associations between fetal inherited thrombophilia and adverse pregnancy outcomes. Am J Obstet Gynecol. Apr 2006;194(4):947 e941-910.

160. Blair E, Stanley F. Intrauterine growth and spastic cerebral palsy. I. Association with birth weight for gestational age. Am J Obstet Gynecol. 1990;162(1):229-237.

161. de Vries JI, Dekker GA, Huijgens PC, Jakobs C, Blomberg BM, van Geijn HP. Hyperhomocysteinaemia and protein S deficiency in complicated pregnancies. $\mathrm{Br} J$ Obstet Gynaecol. 1997;104(11):1248-1254.

162. Gruenwald P. Growth of the human fetus. II. Abnormal growth in twins and infants of mothers with diabetes, hypertension, or isoimmunization. Am J Obstet Gynecol. 1966;94(8):1120-1132.

163. Mage DT, Donner M. A Unifying Theory for SIDS. Int J Pediatr. 2009;2009:368270.

164. Fish EN. The X-files in immunity: sex-based differences predispose immune responses. Nat Rev Immunol. 2008;8(9):737-744.

165. $\mathrm{Wu} D$, Zou YF, $\mathrm{Xu} X Y$, et al. The association of genetic polymorphisms with cerebral palsy: a meta-analysis. Dev Med Child Neurol. 2011;53(3):217-225.

166. Wong L, Maclennan AH. Gathering the evidence: Cord gases and placental histology for births with low Apgar scores. Aust N Z J Obstet Gynaecol. 2011;51(1):17-21.

167. Glessner JT, Wang K, Cai G, et al. Autism genome-wide copy number variation reveals ubiquitin and neuronal genes. Nature. 2009;459(7246):569-573. 


\section{References}

168. McMullan DJ, Bonin M, Hehir-Kwa JY, et al. Molecular karyotyping of patients with unexplained mental retardation by SNP arrays: a multicenter study. Hum Mutat. 2009;30(7):1082-1092.

169. Heinzen EL, Radtke RA, Urban TJ, et al. Rare deletions at $16 \mathrm{p} 13.11$ predispose to a diverse spectrum of sporadic epilepsy syndromes. Am J Hum Genet. 2010;86(5):707-718.

170. Yang J, Benyamin B, McEvoy BP, et al. Common SNPs explain a large proportion of the heritability for human height. Nat Genet. 2010;42(7):565-569. 
Appendices

\section{Appendices}

\section{Appendix 1 Published systematic literature review (Chapter 1)}

O'Callaghan, M.E., MacLennan, A.H., Haan, E.A. \& Dekker, G. (2009) The genomic basis of cerebral palsy: a HuGE systematic literature review

Human Genetics, v. 126 (1), pp. $149-172$

NOTE:

This publication is included on pages $451-474$ in the print copy of the thesis held in the University of Adelaide Library.

It is also available online to authorised users at:

http://dx.doi.org/10.1007/s00439-009-0638-5 


\section{Appendix 2 Published study protocol (Chapter 2)}

O'Callaghan, M.E., MacLennan, A.H., Gibson, C.S., McMichael, G.L., Haan, E.A., Broadbent, J., Priest, K., Goldwater, P.N. \& Dekker, G.A. (2011) The Australian Cerebral Palsy Research Study Protocol for a National Collaborative Study Investigating Genomic and Clinical Associations with Cerebral Palsy.

Journal of Paediatrics and Child Health, v. 47 (3), pp. 99-110

NOTE:

This publication is included on pages 475-486 in the print copy of the thesis held in the University of Adelaide Library.

It is also available online to authorised users at:

http://dx.doi.org/10.1111/j.1440-1754.2010.01896.x 